RAUL FELIPE BORELLI

\title{
ASPECTOS JURÍDICOS DA GESTÃO COMPARTILHADA DOS SERVIÇOS PÚBLICOS DE SANEAMENTO BÁSICO
}

Faculdade de Direito da Universidade de São Paulo

São Paulo

2010 


\section{RAUL FELIPE BORELLI}

\section{ASPECTOS JURÍDICOS DA GESTÃO COMPARTILHADA DOS SERVIÇOS PÚBLICOS DE SANEAMENTO BÁSICO}

Dissertação apresentada ao Programa de Pós-Graduação da Faculdade de Direito da Universidade de São Paulo.

Orientadora: Prof $^{a}$. Maria Sylvia Zanella Di Pietro.

Faculdade de Direito da Universidade de São Paulo

São Paulo

2010 


\section{UNIVERSIDADE DE SÃO PAULO}

\section{FACULDADE DE DIREITO}

\section{PROGRAMA DE PÓS-GRADUAÇÃo}

Dissertação intitulada ASPECTOS JURÍDICOS DA GESTÃO COMPARTILHADA DOS SERVIÇOS PÚBLICOS DE SANEAMENTO BÁSICO, de autoria de RAUL FELIPE BORELLI, analisada pela banca examinadora constituída pelos seguintes professores:

São Paulo, 


\section{AGRADECIMENTOS}

Agradeço aos meus pais e irmãos pelo apoio constante e sincero e, ainda, pela compreensão das dificuldades e limitações impostas pelo desafio acadêmico. Nada seria possível sem a presença de minha família.

À Professora Maria Sylvia Zanella Di Pietro, devo a oportunidade de vivenciar a experiência do mestrado, bem como sou grato pelo espírito receptivo e aberto com que exerceu o trabalho de orientação.

Atribuo ao Professor Antonio Augusto Anastasia muito de minha formação profissional, tendo sido fundamental seu incentivo para o ingresso na Faculdade de Direito da Universidade de São Paulo.

Aos familiares de São Paulo, sou grato pelo zelo que me foi dedicado, em especial Fábio e Tia Renata, que me receberam em suas casas com boa vontade e atenção.

Aos amigos da Manesco Advocacia em geral e, em especial, a Marcos Perez, a Floriano de Azevedo Marques e a José Roberto Manesco, agradeço o suporte e a oportunidade de desenvolver um trabalho enriquecedor. A Marcos Perez agradeço, ainda, sua disposição em partilhar conhecimentos preciosos que somente a experiência é capaz de construir.

Sou grato ao amigo Danilo Tavares pela paciência em ouvir e aconselhar. Como colegas de mestrado e de profissão, compartilhamos muitas das ansiedades trazidas pela tarefa de escrever.

Os esclarecimentos dados por Wladimir Antonio Ribeiro foram essenciais para o bom desenvolvimento da dissertação.

Devo a Osvaldo e Laura a oportunidade de conviver, durante a estada em São Paulo, com figuras inspiradoras e únicas e que tornaram bem mais fácil a vida em uma nova cidade.

Em relação aos amigos de Belo Horizonte, Leo, Frederico, Estevão e Maurício, não posso esquecer as conversas tranquilizadoras e a atenção dedicada ao momento que vivi.

Agradecimentos especiais são devidos a Vinícius Marins, não apenas pela amizade sincera, mas pelas leituras e sugestões fundamentais e sempre pertinentes a respeito do trabalho.

Impossível retribuir a atenção e a dedicação recebidos de Anelisa durante todos os anos em que convivemos. 
O livro não é mais o meu pensamento, uma vez que este se tornou um objeto no meio do mundo, algo que pertence aos outros e me escapa. [...] Estava consciente de que, quando tudo tiver sido dito, tudo ainda ficará por dizer, sempre restará tudo a dizer, em outras palavras, é o dizer que importa e não o dito [...]

André Gorz. Carta a D. Cosacnaify, 2009, p. 46. 


\section{RESUMO}

Os serviços de saneamento básico, considerando-se o histórico de sua concretização no Brasil, configuram o campo ideal para a aplicação mecanismos de gestão de serviços públicos que possibilitem a atuação coordenada de diversos entes da federação. De fato, se de um lado é possível reconhecer o interesse local que as atividades de saneamento apresentam, de outro deve-se levar em consideração que, muitas vezes, a prestação dos serviços terá caráter regional e ocorrerá em um contexto em que parcela significativa dos Municípios brasileiros não possuirá, isoladamente, condições econômicas de proporcionar a sustentabilidade dos serviços. O renovado arranjo institucional proporcionado pelo art. 241 da Constituição da República, pela Lei Federal n. 11.445/2007, pela Lei Federal n. $11.107 / 05$ e o tradicional arranjo das regiões metropolitanas demonstram, em muitos pontos, a importância da união de esforços entre entes federados para a implantação dos serviços de saneamento. Tal prestação integrada exige peculiar conformação institucional, dotada de normatividade própria, além de requisitos específicos, temas esses aqui examinados desde seus fundamentos até sua organização prática.

Palavras-chave: Serviços públicos. Serviços de saneamento. Gestão associada. Regiões metropolitanas. Cooperação e coordenação federal. 


\begin{abstract}
The sanitation services, on what concerns the history of its concretization in Brazil, configure an ideal field for the appliance of the public services management mechanisms that enable a coordinate action between different federation entities. Indeed, if on one hand it is possible to recognize the local interest that such sanitation activities represents, on the other hand, it must be considered that, many times, the provision of those services will have regional characteristics and will occur in a context in which significant part of the Brazilian municipalities will not have, on its own, economical conditions to sustain the services. The new institutional framework brought by article 241 of the Federal Constitution, by the Federal Laws $11.445 / 2007$ and $11.107 / 05$ and by the well-known arrangement set forth by the metropolitan regions, demonstrate all together the importance of federal entities to unify efforts to implement the sanitation services. Such integrated provision of sanitation services demands a peculiar institutional framework, ruled by specific laws and regulations and specific requirements, matters which are here examined from its foundations to its practical organization.
\end{abstract}

Key-words: Public utilities. Sanitation services. Agreements of public service delegation. Metropolitan regions. Cooperation and coordination of federal entities. 


\section{SUMÁRIO}

INTRODUÇÃ̃O............................................................. 9

1 OS SERVIÇOS PÚBLICOS DE SANEAMENTO BÁSICO:

CONSIDERAÇÕES SOBRE SUA EVOLUÇÃO NO BRASIL....... 16

1.1 O SANEAMENTO E SEU PERCURSO................................................................ 17

1.1.1 Saneamento: fases evolutivas................................................................................... 22

1.1.2 O Planasa................................................................................................................ 29

1.1.3 Efeitos do Planasa: condicionantes para o sistema de gestão compartilhada do saneamento........................................................................... 32

1.2 O ENQUADRAMENTO TIPOLÓGICO DOS SERVIÇOS DE

SANEAMENTO BÁSICO NO BRASIL ............................................................. 37

1.2.1 Uma aproximação conceitual acerca dos serviços públicos ............................. 40

1.2.2 O saneamento como serviço público.................................................................. 50

1.3 O SANEAMENTO E SUA RELAÇÃO COM AS FRONTEIRAS DO

INSTITUTO DOS SERVIÇOS PÚBLICOS: A TENSÃO ENTRE A

COESÃO SOCIAL E A EFICIÊNCIA ECONÔMICA E A GESTÃO

COMPARTILHADA NESSE CONTEXTO......................................................... 56

2 VISÃO GERAL DOS SERVIÇOS DE SANEAMENTO BÁSICO 71

2.1 LINHAS GERAIS DO REGIME JURÍDICO DOS SERVIÇOS DE SANEAMENTO BÁSICO................................................................................. 72

2.2 ABRANGÊNCIA....................................................................................................... 75

2.2.1 Os serviços de água e esgoto................................................................................... 80

2.2.2 A limpeza urbana e coleta e destinação final de resíduos sólidos................... 86

2.2.3 O manejo de águas pluviais...................................................................................... 92

3 OS FUNDAMENTOS DA GESTÃO COMPARTILHADA............. 98

3.1 DELIMITAÇÃO DA GESTÃO COMPARTILHADA ...................................... 98

3.2 FUNDAMENTOS JURÍDICO-CONSTITUCIONAIS: A DELIMITAÇÃO

DA COOPERAÇÃO FEDERAL......................................................................... 99

3.2.1 O federalismo brasileiro: idiossincrasias que afetam a gestão compartilhada.

3.2.2 A Constituição de 1988: mecanismos de relacionamento federativo e sua eficácia normativa.

3.3 FUNDAMENTOS ECONÔMICO-GERENCIAIS DA GESTÃ O

COMPARTILHADA.

3.4 CONCLUSÕES PRELIMINARES.

4 A GESTÃO COMPARTILHADA DO SANEAMENTO SOB O

ASPECTO INSTITUCIONAL

4.1 ORGANIZAÇÃO DAS COMPETÊNCIAS A RESPEITO DO

SANEAMENTO E SEU IMPACTO NA GESTÃO COMPARTILHADA.... 
4.1.1 O desafio da delimitação da titularidade do saneamento: estabelecendo as linhas de compreensão do problema..

4.1.2 Posições em prol da titularidade municipal.

4.1.3 As posições que defendem a relativização da titularidade municipal em favor do Estado.

4.1.4 As posições intermediárias: a titularidade conjugada de Estados e Municípios.

4.1.5 Consolidação de um entendimento a respeito da titularidade........................ 147

4.1.5.1 Ponderação críticas em torno da tese da titularidade compartilhada........... 148

4.1.5.2 Ponderação críticas em torno da tese da titularidade municipal.................. 156

4.1.6 Compreensão das competências normativas à luz da titularidade do saneamento.

4.1.6.1 A elaboração de diretrizes pela União.

4.1.6.2 O papel dos Estados e Municípios na produção normativa acerca do saneamento...

4.1.6.3 Outras competências que afetam o saneamento.

4.2 A GESTÃ O ASSOCIADA DE SERVIÇOS PÚBLICOS.................................... 165

4.2.1 O consórcio público.

4.2.2 O convênio de cooperação.

4.2.3 A gestão associada e a prestação regionalizada de serviços públicos.

4.2.4 A competência para a regulação, fiscalização e organização dos serviços de saneamento na gestão associada.

4.2.5 Notas sobre o planejamento dos serviços no saneamento na gestão associada.

4.2.6 A competência para outorgar concessão, permissão e autorização dos serviços de saneamento.

4.2.7 A prestação dos serviços de saneamento na gestão associada

4.2.9 As empresas estaduais de saneamento na gestão associada

4.3 AS REGIÕES METROPOLITANAS: UM OLHAR SOBRE OS SEUS DESAFIOS INSTITUCIONAIS.

4.3.1 Em busca de premissas jurídicas a respeito do regime das regiões metropolitanas

4.3.2 A interface entre a gestão associada e as regiões metropolitanas....................

4.3.3 A estruturação dos serviços de saneamento nas regiões metropolitanas.....

4.4 NOTAS SOBRE O FINANCIAMENTO DOS SERVIÇOS NA GESTÃO

COMPARTILHADA: OS SUBSÍDIOS CRUZADOS. 


\section{INTRODUÇÃO}

O regime jurídico dos serviços de saneamento básico é, como se sabe, abrangente. Possui interface com uma diversidade de questões (saúde, meio ambiente, recursos hídricos, repartição de competências entre entidades da federação, etc.) que conformam, em seu conjunto, um sistema complexo e ainda em construção.

A prestação dos serviços de saneamento não é algo novo no esquema administrativo brasileiro. Pode-se dizer que durante todo o século XX houve nítido esforço de universalização desses serviços no Brasil.

A novidade do tema reside, sob tal perspectiva, não no surgimento de uma nova atividade no rol constitucional de serviços públicos, mas no renovado arranjo organizacional que a ela se proporciona, advindo do relativamente recente marco regulatório simbolizado pela Lei Federal n. 11.445/2007. De fato, em comparação com outros setores regulados, o saneamento recebeu regulamentação tardia, que inova em muitos aspectos, pretendendo, em alguns, casos, sedimentar e pacificar velhas discussões.

Dentre as inúmeras novidades, destaca-se, na nova legislação, uma tendência à valorização da prestação dos serviços pelos entes locais (Municípios), ainda que a lei não tenha sido clara nesse ponto

Tal valorização, se de um lado representa o reconhecimento do interesse local que tais atividades assumem, de outro deve levar em consideração que, muitas vezes, a prestação dos serviços terá nítido caráter regional e ocorrerá em um contexto em que parcela significativa dos Municípios brasileiros não possuirá, isoladamente, condições econômicas de proporcionar a sustentabilidade dos serviços. Por isso, a união de esforços entre entes federados para a implantação dos serviços de saneamento será alçado a mote principal deste trabalho.

Por se tratar de um tema referenciado em todos os capítulos do trabalho, é imprescindível, desde já, delimitar as linhas gerais da gestão compartilhada do saneamento.

Com efeito, na abordagem proposta, os instrumentos e mecanismos destinados a implantar e conferir efetividade ao relacionamento entre os diferentes entes federados na prestação do saneamento serão congregados em torno da noção de gestão compartilhada. 
A expressão "gestão compartilhada" foi propositadamente escolhida por diferenciar-se da "gestão associada" de serviços públicos (prevista no art. 241 da Constituição da República) e aqui compreendida como uma manifestação específica da própria gestão compartilhada.

Verifica-se, nesse ponto, que essa expressão tem um sentido mais abrangente, que permite aglutinar-lhe de modo satisfatório as situações em que ocorrerá a prestação coordenada dos serviços entre dois ou mais entes federados, seja em razão da gestão associada de serviços públicos de que trata o art. 241 da Constituição da República, seja por força de mecanismos de desenvolvimento de funções públicas de interesse comum como as regiões metropolitanas, as aglomerações urbanas e as microrregiões.

No que toca ao saneamento, as causas motivadoras da gestão compartilhada são as mais variadas, sendo possível citar como exemplos:

(i) a tentativa de obtenção de uma escala que ofereça sustentabilidade à prestação dos serviços, tendo em vista a baixa capacidade de financiamento das atividades pelo Poder Público local e pela população;

(ii) a existência de regiões metropolitanas, aglomerações urbanas e microrregiões, exigindo, em muitos casos, uma gestão conjunta dos serviços públicos;

(iii) as dificuldades de acesso a corpos hídricos ou a áreas de disposição final de resíduos;

(iv) a adaptação da prestação de serviços às características das bacias hidrográficas de cada região;

(v) as políticas de universalização dos serviços patrocinadas por entes federados de maior abrangência territorial, como os Estados e a União, e que têm como pressuposto a regionalização dos serviços;

(vi) a padronização da regulação dos serviços em determinada região.

Nesse contexto, a gestão compartilhada representa uma circunstância especial, na qual atores públicos e privados, normas constitucionais, legais e regulamentares, e condicionantes geográficos, econômicos e ambientais congregam-se de forma a justificar uma prestação conjunta dos serviços de saneamento por dois ou mais entes federados.

Tal prestação conjunta exigirá peculiar conformação organizacional para a implantação e o desenvolvimento dos serviços de saneamento, dotada de normatividade 
própria e de requisitos específicos para sua instauração, bem como exigirá a compatibilização dos diferentes instrumentos jurídicos tradicionalmente aplicados na gestão de serviços públicos.

Elege-se como foco de pesquisa, em essência, a compreensão de novas formas organizacionais dos serviços públicos, temática que, inevitavelmente, traz ilações complexas referentes à relação entre os setores público e privado, ao caráter econômico que os serviços públicos assumem como bem escasso fornecido à comunidade, às disputas com relação à titularidade dos serviços e às muitas políticas públicas (saúde, meio ambiente, urbanismo e redistribuição de renda) veiculadas por meio da implantação e estruturação do saneamento.

Neste trabalho não se furtará de explorar as relações entre tais questões. Mas, para atingir tais desideratos, impõe-se uma postura metodológica condizente com os novos rumos e tendências identificáveis na pesquisa jurídica hodierna.

Gustin e Dias (2006) informam a possibilidade de adoção de duas grandes vertentes teórico-metodológicas na realização da pesquisa jurídica: a jurídico-dogmática e a jurídico-sociológica.

Segundo as autoras, a primeira vertente trabalha com a noção de autossuficiência metodológica do ordenamento jurídico. Seu foco principal abrange a investigação das relações normativas entre os campos do Direito, bem como a avaliação da estrutura interna do ordenamento jurídico.

Para as autoras em referência, a vertente jurídico-dogmática, embora prioritariamente voltada para a análise da eficiência das relações internas aos institutos jurídicos, não configura modelo absolutamente independente ou autossuficiente. A eficácia das relações normativas deve ser também objeto de investigação, sob pena de um enclausuramento contraposto à noção de que o Direito opera dada realidade. ${ }^{1}$

A perspectiva jurídico-sociológica, por sua vez, tem em vista "compreender o fenômeno jurídico no ambiente social mais amplo" (GUSTIN; DIAS, 2006, p. 22). O Direito, nesse caso, consiste em variável dependente da sociedade. O objeto de estudo

\footnotetext{
1“"Entende-se aqui, contudo, que a vertente jurídico dogmática não necessariamente deve ser considerada metodologicamente autossuficiente. Sem dúvida, trabalha com relações normativas, e não poderia ser de outra forma. Isso não significa, entretanto que deve estar voltado apenas para o interior do ordenamento ou ali enclausurado. As relações normativas devem, também, ser pensadas de forma externa, vital, no mundo dos valores e das relações da vida. Logo, não interessará apenas a eficiência das relações normativas, mas, inclusive, sua eficácia. E isso não transformará a dogmática em um tipo sociológico puro." (GUSTIN; DIAS, 2006, p. 21)
} 
abrangeria a realização concreta na sociedade das finalidades almejadas por leis, regulamentos e institutos jurídicos, bem com a adequação destes aos anseios e necessidades sociais. ${ }^{2}$

A separação estanque das vertentes metodológicas descritas parece de difícil realização prática. As atividades de pesquisa e interpretação jurídica vêm passando por visível transformação. Não se identificam mais com a mera interpretação da lei, devendo ser encaradas como atos que contribuam para realização do Direito na sociedade. ${ }^{3}$

No Direito Administrativo, especialmente no ramo direcionado aos serviços públicos, sente-se progressivamente o imperativo de cotejo da realidade jurídica, seus dogmas e postulados, com as possibilidades fáticas impostas pela realidade social.

A organização jurídica dos serviços públicos deve relacionar-se dialeticamente com as imbricações socioeconômicas dos setores normatizados, em um jogo de condicionamento mútuo em que o Direito seja capaz de impor valores e, quando necessário, adaptar-se às condições fáticas aferíveis concretamente.

Busca-se, assim, um Direito que ultrapasse imposições deterministas e que seja considerado um efetivo instrumento de transformação social. Nesse caso, a concepção metodológica adotada simboliza, também, a tentativa de comprovação, ainda que pelo prisma do regime jurídico dos serviços de saneamento básico, da capacidade do Direito

2 “A segunda vertente, jurídico-sociológica, propõe-se a compreender o fenômeno jurídico no ambiente social mais amplo. Analisa o Direito como variável dependente da sociedade e trabalha com as noções de eficiência, eficácia e de efetividade das relações direito/sociedade. Preocupa-se com a faticidade do Direito e com as relações contraditórias que estabelece com o próprio Direito e com os demais campos: sociocultural, político e antropológico." (GUSTIN; DIAS, 2006, p. 22)

3 Segundo Neves (2003, p. 11-12), "o problema da interpretação jurídica está, com efeito, a sofrer uma radical mudança de perspectiva no atual contexto metodológico. Deixou de conceber-se tão-só e estritamente como interpretação da lei, para se pensar como actus da realização de direito. E isto significa, por um lado, que a realização do direito não se identifica com a interpretação da lei, nem nela se esgota; por outro lado, que não será em função da interpretação da lei, tomada abstratamente ou em si, que havemos de compreender a realização do direito - em termos de se dizer que esta será o que for aquela -, antes é pela problemática autônoma e específica da realização do direito, e como seu momento metodológico-normativo, que se haverá de entender o que persiste dizer-se interpretação da lei. Com o que o próprio conceito de interpretação jurídica se altera: de interpretação da lei converte-se em interpretação do direito, de novo a interpretatio legis se confronta com a interpretatio juris.

É que, se intencional e normativamente o direito deixou de identificar-se com a lei, também metodologicamente a realização do direito deixou de ser mera aplicação das normas legais e manifesta-se como o acto judicativamente decisório através do qual, pela mediação embora do critério jurídico possivelmente oferecido por essas normas, mas com ampla actividade normativamente constitutiva, se cumprem em concreto as intenções axiológicas e normativas do direito, enquanto tal. Dir-se-á que, nestes termos, o pensamento jurídico recuperou o concreto, que vai na essencial vocação do direito, depois que o positivismo legalista, com o seu normativismo analítico-dedutivo, o levara a refugiar-se no alienante abstracto". 
Administrativo e do corpo teórico por ele representado de conformar a realidade e realizar os desígnios fundamentais nele propostos.

A seguir, uma síntese do conteúdo dos capítulos da dissertação tendo em vista o entendimento geral do trabalho:

- Capítulo 1 - Nesse capítulo buscou-se compreender a evolução histórica dos serviços de saneamento básico no Brasil. Demonstrou-se que o legado advindo das políticas públicas anteriores relativas ao saneamento básico condicionam, inevitavelmente, a atual gestão dos serviços, direcionando naturalmente a prestação dos serviços em torno da noção de gestão compartilhada.

Sem a perspectiva de esgotar a linha evolutiva dos serviços públicos, no capítulo destacaram-se notas pontuais dessa evolução com o objetivo de aplicá-las, na medida do possível, aos serviços de saneamento básico. Buscou-se a delimitação de uma noção de serviço público de caráter funcional, que permitiu o enquadramento dos serviços de saneamento básico e sua melhor intelecção no curso do trabalho. Em suma, teve-se como meta a solidificação de pressupostos conceituais relevantes para o entendimento dos novos sistemas organizacionais dos serviços de saneamento.

Do ponto de vista metodológico, nesse capítulo partiu-se do pressuposto de que a compreensão da gestão compartilhada não é possível sem antes a consolidação de noções primordiais sobre os serviços públicos de saneamento.

- Capítulo 2 - Nesse capítulo foram descritas as normas legais fundamentais dos serviços de saneamento, proporcionando sua visão consolidada e preparando discussões mais densas relacionadas à delegação de competências entre entes federados por meio da gestão compartilhada de serviços públicos.

Buscou-se, também, uma descrição estrutural das atividades integrantes do saneamento, pressuposto para compreensão das variadas formulações institucionais passíveis de aplicação no setor (no âmbito da gestão compartilhada, naturalmente).

De fato, somente uma visão estrutural permite compreender as características econômicas e concretas dos serviços como necessidade de escala, estruturação em rede, volume de investimentos característico de cada fase da implantação do saneamento e divisão interna de atividades. Sem esse embasamento mínimo, nenhuma análise a respeito 
da gestão dos serviços será possível (notadamente a gestão compartilhada), ainda que tal visão tenha foco nos aspectos jurídicos, os quais, diga-se de passagem, se encontram profundamente imbricados com a dimensão econômica dos serviços públicos.

- Capítulo 3 - Nesse capítulo foram descritos os principais fundamentos da prestação compartilhada dos serviços de saneamento. Tais fundamentos se situam no regime jurídico-constitucional delimitador das relações intergovernamentais no Brasil e também em diretrizes econômicas e gerenciais. A evolução do federalismo em nosso país é um importante ponto de apoio para a análise crítica pretendida, que não se furtou a destacar os elementos políticos e econômicos que tornam o conhecimento mínimo a respeito do sistema federal brasileiro uma condição imprescindível para a compreensão da gestão compartilhada dos serviços de saneamento básico.

- Capítulo 4 - Com este capítulo objetivou-se compreender os principais institutos aplicáveis à instauração da prestação compartilhada dos serviços de saneamento.

Um importante aspecto desse capítulo reside no confronto das posições teóricas e dos posicionamentos jurisprudenciais sobre a titularidade de competências para prestação de serviço público no âmbito da gestão compartilhada.

Desse modo, deu-se ao capítulo um enfoque institucional, voltado para o entendimento da gestão associada de serviços públicos de que trata o art. 241 da Constituição da República e das regiões metropolitanas, aglomerações urbanas e microrregiões, bem como das distintas funcionalidades que cada uma destas figuras pode assumir.

O objetivo foi identificar as possíveis divisões e delegações de tarefas, responsabilidades e atribuições.

Trata-se, nesse sentido, de uma análise a respeito do "invólucro" da prestação compartilhada, sua forma de realização institucionalizada, que permitiu, na medida do necessário, discussões sobre o conteúdo da gestão compartilhada.

- Capítulo 5 - Trata-se da conclusão, dispensando maiores digressões a respeito. 
Observa-se, pelo exposto, que a escolha e o desenvolvimento do tema pautaram-se pela sua potencialidade como amostra de um nítido processo evolutivo no Direito Administrativo brasileiro e que permitirá, em maior medida, não uma visão restrita, mas a investigação da evolução do conceito dos serviços públicos de saneamento básico. Um estudo jurídico em gradações, a abranger desde aspectos de índole teórica, a respeito do papel do Estado perante a sociedade, até questões voltadas para o entendimento do direito positivo pátrio em seus aspectos práticos. 


\title{
1 OS SERVIÇOS PÚBLICOS DE SANEAMENTO BÁSICO: CONSIDERAÇÕES SOBRE SUA EVOLUÇÃO NO BRASIL
}

\begin{abstract}
Neste capítulo buscou-se descrever criticamente a evolução dos serviços públicos de saneamento básico no Brasil. A proposta descritiva não se concretizou apenas sob o viés histórico, mas também sob o prisma da natureza dos serviços, na tentativa de aproximar o estudo do saneamento e a compreensão do instituto do serviço público.

É inegável que o processo evolutivo do setor movimenta-se por circunstâncias que lhe conferem caracteres que, senão únicos, afastam-no, em muitos aspectos, da linha de desenvolvimento seguida por outros grandes serviços públicos influenciados por outras condições jurídico-institucionais e de mercado, além de pressupostos tecnológicos distintos.
\end{abstract}

Com o objetivo de capturar tais matizes de modo claro, o esforço analítico consubstanciado neste capítulo desdobrou-se inicialmente na verificação da construção histórica dos serviços.

O importante, nesse ponto, não foram necessariamente datas e marcos puramente temporais, mas a individualização de uma transformação da faceta do saneamento básico que vai de instrumento de saúde pública até sua consideração como insumo para a manutenção da força de trabalho, para a expansão urbana e, em determinados períodos históricos, para a legitimação de regimes autoritários de governo perante a população.

O peso do passado acarreta até hoje importantes limitações na gestão dos serviços, fato que alça a discussão da prestação compartilhada à linha de frente dos debates sobre a evolução do saneamento.

Em seguida, os serviços de saneamento foram posicionados no âmbito do variado espectro tipológico dos serviços públicos no Brasil, como parte da estratégia de delinear os limites fundamentais do setor.

Estabelecidas essas linhas gerais, colocou-se à prova o saneamento. O cotejo do setor com as fronteiras atuais do instituto dos serviços públicos exerce a importante função de evidenciar suas tendências evolutivas e alguns dos seus desafios. 
Em que pese não ser o objetivo fundamental neste capítulo, não se deve recusar a importância de uma análise contextual em que aspectos fundamentais da evolução do instituto dos serviços públicos no Brasil e em outros países foram trazidos à tona, seja para asseverar fatores de identidade com o saneamento, seja para acentuar diferenças que exigem dos operadores do Direito e administradores esforços especiais em busca de uma adequada estruturação dos serviços em questão.

Uma oportunidade, ainda, para a delimitação de um cenário onde, direta ou indiretamente, se debatem inúmeras das grandes questões que afetam os serviços públicos como gênero.

Ao final, o objetivo foi atingir o elemento de conexão com o objeto principal da pesquisa: a gestão compartilhada do saneamento. De fato, a gestão compartilhada de saneamento pode ser uma resposta interessante às pressões e demandas políticas e econômicas vivenciadas pelos serviços públicos.

O salto que, neste capítulo, ocorre entre a análise do serviço público de saneamento como conceito e a gestão compartilhada como forma de gestão é, assim, proposital e benfazejo, pois inaugura uma linha de raciocínio que vai do conteúdo (aspectos jurídicos e materiais do saneamento) dos serviços, até sua forma de gestão (compartilhada), possibilitando uma visão global do contexto onde tais questões se assentam.

\subsection{O SANEAMENTO E SEU PERCURSO}

A análise histórica do saneamento não deve ser uma simples enumeração de atos no tempo. A síntese evolutiva é uma excelente oportunidade para a gradual construção da feição contemporânea dos serviços. É elevada a influência que a conformação passada do saneamento produziu na organização jurídica hoje vigente a respeito dessas atividades. Muitas das limitações existentes, dos avanços conquistados e das características institucionais do saneamento se devem às decisões políticas tomadas pelas sucessivas administrações no curso do tempo. 
A demonstração dessa interação histórica é o principal escopo deste item deste capítulo. Por isso, priorizou-se a experiência brasileira no percurso do saneamento na história.

Nada impede que se antecipe a conclusão de que o estudo histórico comprova como o federalismo brasileiro, compreendido à luz da gestão de políticas e serviços públicos, com honrosas exceções, não fugiu à regra do centralismo, adquirindo maior abertura apenas após o processo de redemocratização que tem como corolário a Constituição de 1988.

Essa feição da estrutura federal em nosso país será mais bem explorada adiante, quando da compreensão dos fundamentos das manifestações de coordenação e cooperação que integram a gestão compartilhada dos serviços de saneamento (capítulo 3).

Por ora, basta destacar que a concentração das decisões e políticas públicas na esfera da União e dos Estados acarretou no saneamento a progressiva dependência financeira e técnica dos Municípios em relação a tais entes, refletindo-se na atual necessidade de que a prestação dos serviços se dê por meio de instrumentos compartilhados de gestão.

Especialmente no setor de água e esgoto, as políticas públicas voltadas para o desenvolvimento das empresas públicas estaduais e para os investimentos na forma de financiamentos do Banco Nacional de Habitação (BNH) redundaram em modelos de gestão com baixa participação dos Municípios, agravando a dependência por recursos federais e dos estados.

$\mathrm{Na}$ abordagem proposta demonstrou-se que houve, sim, um efetivo incremento na prestação de serviços de saneamento no Brasil, atestado por dados e levantamentos objetivos. Contudo, benéfica em muitos e variados aspectos, a expansão dos serviços não pode obliterar a necessidade de uma visão crítica da evolução do saneamento e de como tal evolução afeta as possibilidades atuais de gestão dos serviços públicos em pauta (gestão compartilhada).

De fato, todos esses condicionantes históricos se refletem na proposição de novos modelos de gestão para os serviços de saneamento, afetando sua viabilidade e governança. 
$\mathrm{Na}$ análise histórica demonstrou-se, também, como a organização jurídicoinstitucional de serviços públicos se relaciona com processos de mobilidade social e distribuição de valores públicos.

Para Reis e Schwartzman (2005, p. 1-2), as desigualdades sociais podem se originar: (i) de processos de exclusão social, em que setores e indivíduos antes integrados à sociedade (com acesso à renda, emprego, etc.) são repelidos ou marginalizados por circunstâncias sociais, políticas e econômicas, (ii) ou em função de um processo de inclusão social limitada, em que o acesso à renda, ao emprego, aos benefícios e aos serviços essenciais encontra-se historicamente circunscrito a um círculo reduzido de indivíduos ou categorias.

Ainda segundo Reis e Schwartzman (2005, p. 1-2), os processos de exclusão ou inclusão limitada apresentam características bem distintas.

A exclusão social tende a produzir contextos instáveis e de caráter traumático, enquanto a inclusão limitada proporciona maior grau de controle dos ânimos dos setores sociais, já que a gradativo oferecimento de bens e utilidades públicos induz à sensação de atendimento gradual dos anseios dos cidadãos ou, em outras palavras, de um contínuo incremento das condições de vida.

A experiência brasileira se identifica fortemente com os processos de inclusão social limitada, em que o oferecimento de serviços essenciais vem ocorrendo paulatinamente, em progresso ora mais lento, ora mais acelerado, fato que se reflete nos indicadores do país. ${ }^{4}$

\footnotetext{
${ }^{4}$ Nas palavras dos citados autores, "dados estatísticos das últimas décadas mostram que os indicadores relativos à educação, saúde, habitação, seguridade social e consumo de bens duráveis vêm aumentando progressivamente, mas a partir de bases iniciais bastante restritas, que ainda colocam o Brasil em situação bastante desfavorável em comparações com outros países da região. Este progresso lento, mas contínuo dos indicadores sociais, inclusive em períodos de estagnação econômica, talvez expliquem porque o Brasil tenha se mantido relativamente tranqüilo, politicamente, ao longo destes anos, assim como a orientação conservadora de boa parte de seu eleitorado.

No entanto, a concentração populacional nas grandes cidades, a reestruturação do setor industrial e o pouco crescimento econômico estão criando um novo elenco de carências e problemas, relacionados ao desemprego, à desorganização e violência urbana, à insegurança pessoal e à deterioração de alguns serviços públicos, como na área da saúde pública, com a volta de enfermidades contagiosas que já se consideravam extintas. Isto, combinado com a insatisfação crescente com a lentidão dos processos de exclusão em outros setores, cria uma situação difícil, em que a distinção entre os que são excluídos porque perderam o que tinham, ou porque nunca tiveram, começa a perder sentido.

Não há dúvida de que as principais explicações para os processos de longo prazo de exclusão-inclusão são econômicas, mas em forte associação com instituições políticas e elementos sociais e culturais." (REIS; SCHWARTZMAN, 2005, p. 1-2)
} 
Nesse contexto se enquadram as políticas públicas de saneamento, as quais provocaram, inegavelmente, um incremento das condições de vida da população, mas não lograram atingir a meta da universalização com plenitude (inclusão limitada).

No que toca aos serviços de água e esgotamento sanitário, atividades nas quais os dados são mais densos e detalhados, a evolução do atendimento à população, embora existente, ainda não contempla a totalidade das necessidades sociais.

Segundo dados do Instituto Brasileiro de Geografia e Estatística (IBGE), em 2000 (data em que grande estudo a respeito do saneamento foi elaborado) existiam, no Brasil, 2.958.831 domicílios cujo abastecimento de água era realizado por meios distintos da utilização de poço ou nascente na propriedade e 3.705.308 domicílios em que não havia banheiro ou sanitário.

Em relação ao esgotamento sanitário, havia 10.594 .752 domicílios que utilizavam a fossa rudimentar; 1.154.910, a vala; e 1.110.021, rios, lagos ou mar como forma de esgotamento.

Os dados indicam que a cobertura dos serviços de abastecimento de água da população urbana cresceu de $87,8 \%$ para $89,8 \%$. Por sua vez, o acesso da população rural não atingiu, então, $20 \%$ dos potenciais usuários. Em relação aos serviços de esgotamento sanitário, seja por rede geral ou fossa séptica, a cobertura pela população urbana passou de $64,4 \%$ para $72,0 \%$ e da população rural de $9,5 \%$ para $12,9 \%$.

O Sistema Nacional de Informações sobre o Saneamento (SNIS) nos oferece dados mais recentes:

TABELA 1

Níveis de atendimento urbano com água e esgotos dos prestadores de serviços participantes do SNIS em 2006, segundo a abrangência

\begin{tabular}{c|c|c|c}
\hline \multirow{2}{*}{ ABRANGÊNCIA } & \multicolumn{3}{|c}{ ÍNDICE DE ATENDIMENTO URBANO (\%) } \\
\cline { 2 - 4 } & Água & Coleta de esgotos & $\begin{array}{c}\text { Tratamento dos esgotos } \\
\text { gerados }\end{array}$ \\
\hline Regional & 93,1 & 42,2 & 34,5 \\
Microrregional & 100,0 & 48,7 & 64,2 \\
Local & 92,8 & 69,7 & 25,0 \\
Brasil & 93,1 & 48,3 & 32,2 \\
\hline
\end{tabular}


TABELA 2

Níveis de atendimento urbano com água e esgotos dos prestadores de serviços participantes do SNIS em 2006, segundo a região geográfica

\begin{tabular}{c|c|c|c}
\hline \multirow{2}{*}{ ABRANGÊNCIA } & \multicolumn{3}{|c}{ ÍNDICE DE ATENDIMENTO URBANO (\%) } \\
\cline { 2 - 4 } & Água & Coleta de esgotos & $\begin{array}{c}\text { Tratamento dos esgotos } \\
\text { gerados }\end{array}$ \\
\hline Norte & 62,7 & 6,1 & 8,4 \\
Nordeste & 92,5 & 26,4 & 31,9 \\
Sudeste & 95,7 & 69,6 & 33,7 \\
Sul & 99,2 & 35,2 & 28,2 \\
Centro oeste & 98,0 & 45,9 & 42,8 \\
Brasil & 93,1 & 48,3 & 32,2 \\
\hline
\end{tabular}

Fonte: SNIS, 2007, p. 103-104

Verificado que muito ainda há de ser empreendido no setor do saneamento, assevera-se que uma das premissas fundamentais para o desenvolvimento deste capítulo, ainda com o apoio de Reis e Schwartzman (2005, p. 2), é a de que "as principais explicações para os processos de longo prazo de exclusão-inclusão são econômicas, mas em forte associação com instituições políticas e elementos sociais e culturais".

Com efeito, os serviços públicos não podem ser considerados como o único fator impulsionador de incremento das condições de vida da população, por isso a análise será realizada com base no contexto econômico, institucional e político da sociedade.

Aproximando a questão do tema ora tratado, o arcabouço institucional criado para a concretização dos serviços públicos representa o grande painel ou pano de fundo cuja interpretação levará a soluções de universalização condizentes com as características concretas da sociedade brasileira:

Como no passado, estes altos níveis de pobreza e exclusão são causados por uma combinação de heranças, condições e escolhas de natureza econômica, política e cultural. É ingênuo supor que a pobreza e a desigualdade poderiam ser eliminadas pela simples 'vontade política', ou pela redistribuição de recursos dos ricos para os pobres. [...].

Uma pesquisa sobre a exclusão social no Brasil não pode deixar de incluir uma análise dos direitos sociais legalmente estabelecidos, buscando quantificar em que medida estes direitos estão sendo atendidos. Mas uma análise que se limitasse a cotejar os direitos formais com seu atendimento deixaria de lado dois aspectos cruciais desta questão, que são os mecanismos pelos quais o setor público vem, ou não, procurando atender a estes direitos, e as formas que a sociedade tem buscado para garantir que estes direitos sejam atendidos, e que, na sua ausência, criam as situações de exclusão.

E como entender a dinâmica, o processo que gera e recria exclusão? Sabemos que entram em jogo aqui fatores de ordem econômica, social, política e cultural. 
Os mecanismos que cerceiam a cidadania plena e mantém tantos membros de uma nação alijados de direitos de jure assegurados a todos são múltiplos, dinâmicos e interdependentes. Contudo, é possível e desejável organizá-los e classificá-los como recursos de análise. Nesse sentido é que se fala das dimensões econômica, cultural e político-institucional dos processos de exclusão. (REIS; SCHWARTZMAN, 2005 p. 3-8, grifos nossos)

Por meio da apresentação da organização institucional do saneamento no curso da gestão pública brasileira, compreende-se que a alternativa da gestão compartilhada, mais do que uma criação inovadora do legislador, é produto de forças históricas poderosas, acalentadas durante os anos de formação da estrutura burocrática do Estado brasileiro no século XX.

Convém justificar o fato de que parte considerável das digressões históricas ora realizadas transita pela experiência do setor de água e esgoto. Trata-se da área nas quais os esforços públicos foram mais concentrados, apresentando dados e referências em maior volume, permitindo que os efeitos das políticas adotadas fossem analisados com precisão maior.

\subsubsection{Saneamento: fases evolutivas}

Em linhas gerais, verifica-se que os modelos de gestão adotados para o saneamento refletem as diferentes formas de financiamento dos serviços valorizadas ou escolhidas pelo setor público em determinados momentos.

Cavalcanti (1985), citado por Jorge (1987, p. 64) distingue três grandes períodos evolutivos: (i) o primeiro, que se iniciou na segunda metade do século XIX, período em que a urbanização brasileira começou a adquirir contornos mais precisos; (ii) o segundo, com início nas décadas de 1920 e 1930, presenciou a reformulação do papel do Estado no desenvolvimento do saneamento, que passou a implantar e gerir predominantemente os sistemas; e (iii) o terceiro período, cujas primeiras manifestações ocorreram na década de 1960, deu início à chamada "era Planasa".

As fases destacadas não são estanques. Representam, antes, uma divisão didática do que uma cronologia absoluta a respeito da evolução do saneamento. 
Como dito, o primeiro período teve início a partir da segunda metade do século XIX, época em que os sistemas foram implantados juntamente com outras infraestruturas voltadas para a exportação de bens. Os capitais predominantes nessa fase de instalação do saneamento foram o de origem mercantil e o estrangeiro.

O período em análise coincide com o início do processo de urbanização brasileiro. $\mathrm{O}$ crescimento das cidades gerou problemas estruturais que passaram a exigir soluções cada vez mais complexas e elaboradas. Era necessário o oferecimento de suporte sanitário mínimo para atendimento de uma rede urbana de pequeno porte, apoiada em poucas cidades de tamanho significante, centros da burocracia governamental formados e impulsionados por uma economia de base agrícola voltada para a exportação. (JORGE, 1987, p. 62)

O desenvolvimento das cidades pressionou, inevitavelmente, o Poder Público a encontrar soluções que permitissem o aprimoramento das condições de salubridade e redução dos riscos de epidemias. (HELLER; REZENDE, 2008, p. 144)

Desenvolveu-se no Brasil, assim como em outros países do mundo, uma concepção higienista de urbanização, baseada em teorias científicas a respeito da disseminação de doenças, cujo maior divulgador na engenharia foi Saturnino de Brito, responsável por inúmeros projetos sanitários em cidades brasileiras.

Data desse período o início da relação entre saúde pública e saneamento, que marcará a evolução histórica dos serviços no Brasil. Inaugurou-se, nesse momento, parte considerável das grandes obras de saneamento urbano. ${ }^{5}$

O instrumento jurídico fundamental para a instalação dos serviços no período em questão foi a concessão de serviços a empresas privadas, política que permitiu um crescente afluxo de capitais de países industrializados que tinham como finalidade a obtenção de taxas de lucro mais elevadas do que naqueles países. (JORGE, 1987, p. 65)

Assim, a primeira manifestação dos serviços de saneamento ocorreu por meio de prestadoras privadas dos serviços, as quais não lograram atingir os objetivos

\footnotetext{
${ }^{5}$ Jorge (1987, p. 62) nos oferece exemplos das obras realizadas nos períodos: 1842 - elaboração do primeiro projeto de adução e distribuição de água para São Paulo; 1861 - execução do sistema de abastecimento de água de Porto Alegre; 1864 - início de operação da rede de esgotos instalada no centro do Rio de Janeiro; 1873 - implantação de rede de esgotos em área restrita de Recife; 1876 - funcionamento de rede de esgotos em São Paulo, implantada pela Cia. Cantareira; 1876 - início da construção da rede de distribuição domiciliar de água, no Rio de Janeiro; 1880 - primeira instalação pública de filtros de pressão no Brasil, em sistema de abastecimento de água, na cidade de Campos; 1891 - inauguração do serviço de água de Campinas, com adutora em tubos de aço; 1897 - inauguração da cidade de Belo Horizonte, com redes de água e esgoto; 1907 - Início das obras de saneamento de Santos, por Saturnino Brito.
} 
fundamentais de desenvolvimento da saúde pública, levando gradualmente ao fracasso do modelo. ${ }^{6}$ (REZENDE, 2005, p. 34)

Essa fase perdurou com maior intensidade até a crise econômica de 1929, tendo atravessado a Primeira Guerra Mundial e lastreado as pretensões iniciais de industrialização de nosso país. De fato, o saneamento sempre foi encarado como um importante meio de manutenção da força de trabalho, pressuposto inafastável para o desenvolvimento econômico.

Rezende (2005, p. 34) demonstra que o insucesso do modelo de prestação privada, progressivamente, gerou maior participação do Estado na implantação do saneamento, inaugurando um novo período na história do setor.

$\mathrm{Na}$ tentativa de estabelecer um modelo de prestação direta dos serviços pelos Municípios, foram criadas comissões sanitárias e órgãos federais encarregados de formalizar convênios de fomento aos sistemas municipais. As comissões em questão eram responsáveis pela concepção dos projetos, realização das obras e desempenho das correspondentes ações de educação sanitária da população. (HELLER; REZENDE, 2008, p. 196)

Nessa fase, com início na década de 1920, as ações de saneamento foram preponderantemente realizadas em função de diretrizes de saúde pública, fator que favoreceu os primeiros esforços de centralização da política de saneamento na União.

De fato, constatava-se um movimento robusto em prol da assunção pelo Governo Federal de posturas mais centralizadoras e interventivas no campo da saúde pública, conceito que abarcava as ações de saneamento. Tal como Heller e Rezende (2008, p. 187) bem colocam,

o movimento sanitarista, organizado em torno do desafio da conscientização,
conseguiu mobilizar uma grande parcela da população na busca por soluções de
um problema consagrado como ordem coletiva, notadamente causado pela
sociabilidade da doença. Entretanto, apenas essa consciência social não seria
suficiente para resolver um problema de âmbito nacional. Era necessária a
implantação de uma estrutura que centralizasse a política, caracterizando um
'processo que envolvia atores, instituições, interesses e regras' (HOCHMAN,
1998) [...]. A partir da década de 10, os governos estaduais, sem condições de
resolver os problemas sanitários, começaram a solicitar o auxílio técnico,

${ }^{6}$ Conforme informa Rezende (2005, p. 34), “apenas duas das companhias privadas de saneamento permaneceram atuando até meados do último século: a City, companhia responsável pelo esgotamento sanitário da cidade do Rio de Janeiro, que manteve a concessão dos serviços até 1947, e a City of Santos, companhia responsável pelo abastecimento de água e esgotamento sanitário, cuja concessão durou até 1953". 
financeiro e recursos humanos da União, principalmente para o combate de epidemias de febre amarela e peste.

A centralização adquiriu maior fôlego na década de 1930, já que o Governo Central de Vargas naturalmente atraíra competências administrativas relevantes com o intuito de enfraquecer as oligarquias regionais, os maiores adversários do Estado Novo.

O ímpeto centralizador não era completo ou absoluto, visto que a atuação de órgãos federais como a Inspetoria de Obras Contra a Seca (IOCS), o Departamento Nacional de Obras de Saneamento (DNOS) e o Serviço Especial de Saúde Pública (SESP) se deu em prol da constituição dos serviços a serem administrados, no mais das vezes, pelos próprios Municípios. (SONALY, 2005, p. 35)

Os recursos para investimento passaram a advir fundamentalmente de fundos públicos, muitas vezes sem condições de retorno.

Quanto ao ordenamento jurídico, a edição de Código das Águas em 1934 ofereceu bases mais sólidas para a exploração das fontes de água, permitindo o incremento da prestação.

Caracteriza essa fase a maior relação técnica e financeira do Brasil com o Governo norte-americano. De fato, a criação do já citado Serviço Especial de Saúde Pública (SESP) em 1942 se deu em razão de convênio entre os dois países (em 1948 foi fundada a Associação Interamericana de Engenharia Sanitária e Ambiental (AIDIS):

\begin{abstract}
Nos moldes da gestão de saneamento, via administração direta, mais de 15 instituições federais atuaram em projetos e sistemas de saneamento até o final da década de 60 (BRASIL, 1966). Dentre esses órgãos, PINHEIRO (1992) e BASTOS (1993) destacaram o Serviço Especial de Saúde Pública (SESP), cuja criação foi resultante de uma cooperação entre os governos brasileiro e norteamericano, respondendo, em linhas gerais, às demandas surgidas com a II Guerra Mundial. O SESP foi o único órgão a atuar em todos os processos dos sistemas de saneamento: implantação, operação, manutenção e administração dos serviços de abastecimento de água e esgotamento sanitário, sendo responsável por uma ampliação significativa no número desses sistemas nas cidades brasileiras. (SONALY, 2005, p. 35)
\end{abstract}

Com o apoio do SESP, foram criados cerca de 1.500 sistemas de abastecimento de água no Brasil e centenas de sistemas de esgotamento sanitário, na forma de autarquias diretamente controladas pelos Municípios, denominadas Sistema Autônomo de Água e Esgoto. (SAAE) (SONALY, 2005, p. 37) 
A criação das autarquias foi uma medida intermediária para a promoção da eficiência dos serviços. Almejava-se oferecer aos Municípios estruturas mais flexíveis de organização, dotadas de autonomia financeira e administrativa. Um complemento às tentativas iniciais do SESP, desde aquela época, de instituir um sistema de subsídios cruzados para suplantar os problemas de inviabilidade econômica que se verificava em algumas localidades, proposta prontamente repelida pelos Municípios superavitários. ${ }^{7}$

Por volta da década de 1950, uma renovada conjugação de fatores impulsionou alterações na concepção do modelo de gestão do saneamento. As décadas vindouras viram surgir, gradualmente, uma estrutura de serviços consideravelmente distinta daquela verificada na primeira metade do século XX. Paulatinamente, estavam sendo lançados os fundamentos daquele que seria o maior programa de saneamento do Brasil: o Planasa.

De fato, as mudanças são motivadas pelo estabelecimento de novas condições de financiamento e aporte de recursos, associadas a críticas ao modelo de prestação pela administração direta municipal, como a adoção de políticas tarifárias inadequadas, dificuldades de arrecadação de tarifas pela administração (acarretando dependência de recursos de terceiros para a implantação dos serviços), sem mencionar a sujeição a influências locais de caráter clientelístico e fisiológico. (SONALY, 2005, p. 36)

Assim, a nova proposta de gestão ocorreu em um contexto próprio no que toca ao financiamento da infraestrutura de saneamento e às novas medidas e instrumentos de gestão em voga.

No que concerne às linhas de financiamento, a criação da Superintendência para o Desenvolvimento do Nordeste $\left(\right.$ SUDENE$^{8}$ e do Banco Interamericano de

\footnotetext{
${ }^{7}$ De modo geral, até o período de 1964, os serviços de saneamento foram preponderantemente geridos por órgãos da administração dos Municípios. Nas capitais, a gestão se fazia normalmente por departamentos estaduais de água e esgoto. (JORGE, 1987, p. 67-68)

Essa circunstância se justificava, em parte, pelo contexto econômico do final do período destacado. Notadamente em razão do Programa de Metas do Governo Kubitschek, a União tinha seus esforços voltados para a ampliação das redes de transporte, comunicação e energia. Visava, assim, contornar estrangulamentos no setor de capital. Os esforços para manutenção e expansão da força de trabalho (aos quais o saneamento era ligado como elemento integrante da política de saúde pública) não receberam prioridade já que não havia escassez de mão de obra para o desenvolvimento do país. (JORGE, 1987, p. 67)

${ }^{8} \mathrm{O}$ movimento de concentração dos serviços em níveis federativos mais abrangentes do que o municipal esteve associado ao processo de criação de áreas regionais de desenvolvimento: "Em 1961 formulou-se o primeiro Plano Diretor da Superintendência para o Desenvolvimento do Nordeste (SUDENE), sendo impostas restrições ao financiamento de intervenções em saneamento aos municípios. Neste documento, fica evidente a vinculação entre a transferência dos serviços dos municípios para as empresas ligadas aos governos estaduais ou federais e a efetivação de empréstimos concedidos pela SUDENE. Foram criados mecanismos que objetivavam coordenar ações relacionadas ao abastecimento de água e à coleta de esgotos,
} 
Desenvolvimento (BID), ${ }^{9}$ em 1959, veio acompanhada da imposição de condições para a transferência de recursos para o saneamento, quais sejam: a autonomia dos serviços como requisito para a contratação dos empréstimos e a realização de estudos de viabilidade econômica, que deveriam prever a amortização dos financiamentos por meio da cobrança tarifária. (SONALY, 2005, p. 35-36) ${ }^{10}$

Uma das iniciativas de destaque em prol da transição do modelo se deu por meio do apoio da United States Agency for International Development (USAID) e do incentivo à criação de empresas de saneamento dotadas de estrutura mais eficiente e moderna de gestão. Produto desse apoio foi a instituição do Grupo Executivo do Fundo Nacional de Financiamento para Abastecimento de Água (GEF), em 1965. (SONALY, 2005, p. 36)

A primeira entidade estadual criada segundo os moldes propostos pela USAID foi a Companhia de Saneamento do Paraná (SANEPAR), que iniciou suas atividades em 1964. Também a USAID condicionava seus empréstimos a estudos de viabilidade econômica dos serviços.

Além do viés financeiro representado por agências internacionais de fomento, que tendia para o incentivo à criação de empresas estatais, houve intensificação da criação de autarquias municipais para gestão dos serviços, fato que já se verificava desde a década de 1940.

\footnotetext{
constituindo concessionárias sob o controle da SUDENE, como a Companhia de Águas e Esgotos do Nordeste S.A. (CAENE) e a Companhia Nordestina de Sondagem e Perfuração (CONESP), e incentivando diretamente os estados a criarem as Companhias Estaduais de Saneamento Básico (CESBs) (SUDENE, 1962)." (SONALY, 2005, p. 39)

9 Jorge (1987, p. 70-71) informa a respeito dos resultados dos financiamentos do BID na política de saneamento: "A contribuição do governo americano ao Fundo Fiduciário de Progresso Social, fundo alocado no Banco Interamericano de Desenvolvimento - BID (criado em 1959), gerou os seguintes empréstimos: 1. Ampliação e melhoramento do sistema de água da cidade de Salvador (30/11/61, U\$ 4.120.000 - 50,7\% do custo total do projeto, à Superintendência de Águas e Esgotos do Recôncavo). 2. Ampliação e melhoramento do sistema de água do Estado da Guanabara U\$ 12.500,00 - 23\% do custo total do projeto ao Banco do Estado da Guanabara S.A.). 3. Instalação, expansão e melhoramento dos sistemas de água e esgotos das cidades de Campina Grande, Maceió, Natal, Recife, São Luís e Teresina (U\$ 12.990.000 - 70\% do custo total do projeto). 4. Ampliação e melhoramento do sistema de esgotos do Estado da Guanabara (13/03/62) - U\$ 11.000 .000 - 48,9\% do custo total do projeto ao Banco do Estado da Guanabara). 5. Obras de água e esgotos do Estado do Pará (21/11/63, U\$ 2.500.000 - 51,7\% do custo total do projeto ao Departamento de Água e Esgotos do Estado do Pará)."

${ }^{10}$ Iniciativa parecida foi empreendida com financiamento da USAID, "instituição que coordenou o Grupo Executivo do Fundo Nacional de Financiamento para Abastecimento de Água - GEF, em 1965, a fim de estimular a constituição de empresas mais eficientes e assentadas em modelos mais modernos de gestão. Em 1967, o GEF foi incorporado pelo Banco Nacional da Habitação (BNH), que assumiu os seus compromissos. Com a criação do Sistema Financeiro de Saneamento (SFS), ainda naquele ano, foram reforçadas as diretrizes adotadas pela SUDENE-BID para a obtenção dos financiamentos (COSTA, 1994; REZENDE; HELLER, 2002)”. (SONALY, 2005, p. 36)
} 
Mudanças institucionais significativas continuaram a ocorrer na estrutura governamental de apoio ao saneamento. Na década de 1960, o SESP foi transformado em fundação (FSESP), tendo cessado o fluxo de recursos que o alimentava em razão do fim do convênio com Governo dos Estados Unidos.

Verificou-se, ainda, a redução dos investimentos públicos nas ações preventivas de saúde. $\mathrm{O}$ antigo binômio saúde/saneamento começava a enfraquecer-se. Tomava forma, assim, a bipolarização entre as ações de saúde e saneamento, com esta caminhando gradativamente para uma visão assistencialista e de caráter emergencial, direcionada à cura das doenças e não à sua prevenção.

A atenção médica (ou seja, as medidas de cuidados individuais em detrimento daquelas de caráter coletivo) adquiriu preponderância no Ministério da Saúde (MS), reduzindo-se gradativamente o investimento em saneamento (entre 1949 e 1982 o percentual de recursos do MS aplicados em ações preventivas variou de $87 \%$ para 15\%). (HELLER; SONALY, 2008, p. 227-228)

Também o DNOS $^{11}$ foi progressivamente esvaziado e seus recursos direcionados ao Banco Nacional de Habitação (BNH), que ocupou a posição de principal fonte de financiamento dos serviços, por meio do Fundo de Investimento em Saneamento (FISANE) e Fundo de Garantia por Tempo de Serviço (FGTS).

As restrições orçamentárias impostas às ações de saneamento desenvolvidas na área de saúde, as já citadas críticas ao modelo de prestação pela administração direta dos Municípios e o surgimento de novas fontes de financiamento para os serviços que exigiam modelos de gestão mais eficientes para liberação de recursos impulsionaram, em conjunto, uma significativa modificação na estrutura do setor.

Tem-se, nesse contexto, o lançamento das bases e diretivas que fundamentaram o Planasa a partir da década de 1970: o imperativo de viabilidade econômica dos serviços e maior concentração do controle das políticas de saneamento em nível federal, ao qual cabia intermediar os empréstimos realizados com as instituições internacionais de fomento, tendo em vista a baixa capacidade de contratação dos Municípios e da maior parte dos Estados.

\footnotetext{
${ }^{11}$ Segundo Jorge (1987, p. 116), “em 26 de abril de 1965 foi assinado um acordo entre a USAID e o DNOS estabelecendo o Fundo Nacional de Financiamento para Abastecimento. [...] O Fundo passou a ser gerido por um grupo executivo da própria organização, com a colaboração da Fundação SESP. Esse fundo, face à evolução da política de saneamento adotada pelo Governo Federal, passou a ter uma importância secundária para a própria política de saneamento, sendo absorvido pelo BNH”.
} 
Buscava-se o autofinanciamento dos sistemas de saneamento via tarifas (com a eliminação de subsídios aos serviços), a centralização da política de financiamento via um fundo único e comum e o controle centralizado de toda a política do setor.

Nota-se a progressiva aglutinação das circunstâncias que levarão o saneamento à sua atual conformação e ao estabelecimento da gestão compartilhada como alternativa inescapável para muitos Municípios.

Adiante, serão estabelecidos as principais características do Planasa e o modo como essa peculiar estrutura institucional influenciou o atual regime jurídico das atividades de saneamento básico.

\subsubsection{O Planasa}

O Programa Estratégico de Desenvolvimento (PED) 1968/1970, produzido no início do Governo Costa e Silva, sintetizava bem o ideário vigente a respeito do saneamento (JORGE, 1987, p. 118-119):

a. promover o planejamento e coordenação dos programas de saneamento;
b. concentrar recursos em programas e projetos prioritários, dentro de uma escala
de valores a ser estabelecida pelo órgão nacional de planejamento e coordenação
do programa;
c. substituir o sistema de consignação de recursos orçamentários a fundo
perdido; isto implicará a criação de um mecanismo ao qual será atribuído o
financiamento dos projetos de saneamento, para futura amortização pelas
comunidades beneficiadas;
d. instituir sistema de captação de recursos próprios (não orçamentários), para
estímulo dos programas de saneamento (notadamente no que concerne ao
abastecimento de água e esgoto) [...]. a. instituir o Conselho Nacional de Saneamento, em substituição ao Conselho Nacional de Saneamento Básico, como órgão de coordenação, planejamento e controle da política nacional;

b. instituir um Fundo Nacional de Saneamento, que reunirá recursos nacionais e internacionais, destinados a financiar programas de abastecimento de água e esgotos, para aplicação subordinada a critérios mais racionais e em condições mais realistas de economicidade (com exigência, por exemplo, de reposição pelas populações atendidas);

c. criar um Fundo de Reinvestimento, vinculado ou integrante do Fundo Nacional de Saneamento e formado possivelmente por uma taxa ou sobretarifa a ser cobrada dos usuários dos serviços públicos de água e esgoto (formação de recursos próprios para desenvolvimento auto-suficiente, no futuro, do Programa Nacional de Saneamento. 
$\mathrm{O} \mathrm{BNH}$ foi progressivamente estruturado a fim de atender às demandas do saneamento (JORGE, 1987, p. 121): criação de superintendência especializada para o setor; criação do Programa de Financiamento para Saneamento (FINANSA); estímulo à formação de fundos regionais, estaduais ou intermunicipais para o financiamento de obras (origem dos Fundos de Financiamento para Água e Esgotos - FAEs estaduais) e criação do Sistema Financeiro de Saneamento (SFS).

Em 1969, o Banco foi autorizado a aplicar recursos do FGTS nos sistemas de água e esgoto. Em 1971, foi transformado em empresa pública, consolidando definitivamente uma estrutura empresarial de captação de recursos para aplicação no saneamento (Lei Federal n. 5.762/1971).

No Plano Federal de Metas e Bases para a ação do Governo (1969-1973) figuram os principais objetivos da política de saneamento básico:

\begin{abstract}
Minimização e racionalização das aplicações da União a fundo perdido; tais aplicações serão destinadas, de forma programada, a subsidiar municípios de menor renda na contrapartida, que se torne indispensável aos financiamentos recebidos; Conjugação de esforços dos diversos órgãos federais capazes de colaborar para o êxito do programa definindo-lhes os campos de ação e integrando-lhes os esforços; Atuação de forma descentralizada, através de organismos estaduais e municipais e com observância do princípio de execução indireta, por intermédio do setor privado; Viabilização da operação dos sistemas de água e de esgotos e redução de seu custo operacional através da operação, por um mesmo concessionário, de um conjunto integrado de sistemas municipais; e tarifação que permita a operação, manutenção e expansão do sistema local (e, para a área de saneamento geral). (JORGE, 1987, p. 122)
\end{abstract}

A montagem do Planasa ocorreu em 1971. Importa, nesse momento, empreender uma descrição da estrutura do modelo para, adiante, identificar seus principais efeitos para a atual política e sistema de saneamento.

Buscava o Planasa a eliminação do déficit do setor de saneamento básico, a fim de equilibrar a demanda e a oferta de serviços, no menor tempo, com um mínimo de custo. Pretendia, ainda, o atendimento de todas as cidades brasileiras, mesmo dos núcleos urbanos mais pobres, a instituição de política tarifária renovada (compatível com as possibilidades dos consumidores e com a demanda de recursos e serviços, de forma a manter equilíbrio entre receita e despesa), a redução de custos operacionais e o desenvolvimento de programas de pesquisa, treinamento e assistência técnica. (JORGE, 1987, p. 126) 
Para a montagem do plano, a estrutura do SFS em cada Estado ficou constituída das seguintes entidades:

BNH: órgão central do sistema.

Governos Estaduais: na qualidade de entidades financiadoras responsáveis pelas integralizações dos recursos do FAE.

Agentes Financeiros: preferencialmente, bancos em que os estados são acionistas majoritários. São mutuários dos financiamentos do BNH e dos FAE, isto é, responsáveis pelo financiamento do Plano, em cada Estado, com recursos tomados ao BNH e ao FAE.

Agentes Promotores: entidades estaduais incumbidas da política de saneamento e de seus aspectos técnicos específicos; função normalmente exercida pelas CES.

Órgãos Gestores: órgãos estaduais especializados em gestão financeira, competindo-lhes a administração dos recursos do FAE.

Companhias Estaduais de Saneamento (CES): responsáveis pela execução das obras, operação e manutenção dos sistemas e ressarcimento dos empréstimos provenientes do BNH e dos FAE.

Órgãos Técnicos: órgãos públicos ou entidades privadas contratados pelo BNH para as tarefas de análise de projetos e fiscalização da execução das obras. (JORGE, 1987, p. 129)

A divisão de competências acima descrita evoluiu com os anos, tendo sido consolidada pela Exposição de Motivos n. 03-CDS de 16 de abril de 1975, emitida pelo então Conselho de Desenvolvimento Social.

À União coube fixar critérios de qualidade e padrão da água, normas gerais para o estabelecimento de tarifas para água e esgoto, financiar a construção de sistemas e estabelecer mecanismo de coordenação e controle.

Aos Estados coube elaborar um plano global de atendimento dos Municípios, manter as companhias estaduais de saneamento e fixar e cobrar as tarifas nos termos estabelecidos pela União.

Aos Municípios restou a operação excepcional da infraestrutura de prestação dos serviços, apenas enquanto não transferidas às empresas estaduais de saneamento.

A centralização da política de saneamento foi, portanto, inquestionável. Segundo Turolla (2007, p.199), a necessidade de acesso a financiamentos e a possibilidade de instituição de subsídios cruzados representaram razões principais para a aceitação dessa política pelos Municípios:

Nesse sentido, somente cerca de mil municípios, 1/4 do total então existente, mantiveram a autonomia na gestão e operação dos seus serviços de saneamento. A centralização em nível estadual, em vez do nível municipal, foi escolhida por atender a dois objetivos principais, conforme Ferreira (1995): uma melhor administração dos riscos através de sua concentração e, principalmente, o 
estabelecimento de subsídios cruzados, com regiões mais rentáveis financiando as menos rentáveis.

A ausência de um marco regulatório dos serviços alçou a União e as empresas estaduais ao papel de planejadoras da expansão do setor, observadas as políticas gerais ditadas pelo Governo Federal.

Nesse contexto, pode-se pensar em um sistema rudimentar de planejamento em que determinações federais se mesclavam às estaduais. Seus efeitos resultam visíveis até os dias atuais, seja no que toca à estrutura física dos serviços, seja no que concerne a seus aspectos institucionais.

Nesse contexto, passa-se a discutir os principais efeitos da política do Planasa e sua influência no modelo que será estudado neste trabalho.

\subsubsection{Efeitos do Planasa: condicionantes para o sistema de gestão compartilhada do saneamento}

De forma geral, é inegável que o Planasa provocou uma grande expansão do saneamento. Motta (2007, p. 178) chama a atenção para a evolução verificada no atendimento nos últimos anos:

\footnotetext{
Por vezes tem-se a impressão de que a expansão dos serviços de saneamento no país foi um fracasso total. Mas a evolução da cobertura desses serviços foi significativa. Nos últimos 30 anos, os serviços de água alcançaram mais de 30 milhões de domicílios e o de coleta de esgoto quase 20 milhões de famílias. Nosso índice de cobertura de água é maior que o de muitos países latinoamericanos e até que o de alguns países desenvolvidos.
}

Destaque-se, contudo, que muito há a ser alcançado, sendo o principal desafio atender as camadas mais pobres da população.

A estrutura do saneamento no país, que buscou sistemas economicamente sustentáveis, acabou favorecendo, em alguma medida, a concentração de renda, pois proporcionou maiores investimentos em setores sociais capazes de arcar com os custos tarifários, em um evidente apoio ao crescimento do ímpeto habitacional da classe média. Ainda com o apoio de Motta (2007, p. 178): 


\begin{abstract}
A despeito do crescimento na cobertura dos serviços, o acesso das camadas mais pobres da população está ainda muito abaixo daquele usufruído pelos mais ricos. Dados dos censos demográficos mostram que, de 1980 a 2000, as famílias com renda acima de dez salários mínimos (SM) têm cobertura de água 50\% maior, e na coleta de esgoto a diferença chega a quase $100 \%$. Ou seja, os investimentos no setor, embora majoritariamente públicos, não conseguiram anular os efeitos da concentração de renda pessoal. [...] Por fim, as estimativas das necessidades de saneamento no Brasil ainda sugerem um esforço de investimento bastante significativo. Para atingir metas razoáveis de cobertura de serviço nos próximos 20 anos, estimou-se um montante de investimentos na ordem de US\$ 60 bilhões. Isso significaria uma taxa de inversão anual de $0,5 \%$ do Produto Interno Bruto (PIB) no período.
\end{abstract}

A concentração de renda se deu, ainda, sob o aspecto regional. Regiões e Municípios com condições de suportar o peso dos financiamentos foram naturalmente favorecidos pelo sistema não apenas por conseguirem arcar com os custos financeiros do empreendimento em razão de sua força econômica, como também pelo fato de que a existência de redes já instaladas favorecia-lhes o incremento. De fato, os gastos com as complementações de infraestrutura eram consideravelmente menores que os de instalação de unidades novas onde antes não existia rede qualquer.

Esse ciclo de investimentos, que privilegiava regiões e Municípios maiores e economicamente mais sólidos, resultou em um crescente distanciamento das condições do saneamento em relação a Municípios menores ou integrantes de regiões mais pobres.

Consequência dessa política foi, ainda, a concentração de recursos nas regiões metropolitanas, demonstrando a íntima ligação entre o saneamento e fenômeno urbano.

A concentração de renda resultou ainda da estrutura e padrão de oferta dos serviços, bem como do gargalo financeiro que as empresas do setor enfrentaram a partir da do final da década de 1970 e início da década de 1980. Cavalcanti (1985 apud JORGE, 1987, p. 12) demonstra que,

\footnotetext{
em relação ao padrão de ofertas de serviços, os sistemas implantados são concentradores de renda. As empresas do setor, ao contrário dos objetivos da política do Governo Federal, passaram a apresentar receitas operacionais equivalentes às despesas de operação, inviabilizando a possibilidade de remuneração do capital investido e não impedindo o crescimento generalizado dos serviços e suas dívidas. A importação de tecnologia no setor trouxe elevados padrões de qualidade, de consumo e de exigências de operação e manutenção, concorrendo para a elevação dos custos em geral dos sistemas de saneamento.
}

Para muitos críticos, a política de saneamento do Planasa tinha objetivos muito claros: proporcionar legitimidade do regime militar perante a população e promover o 
crescimento da indústria de construção pesada no Brasil (principal beneficiada pelos grandes investimentos em obras).

Assim é que a Lei Federal n. 6.528, de 11 de maio de 1978, ao determinar que as tarifas deviam obedecer ao regime dos serviços pelo custo, garantindo ao responsável remuneração de até $12 \%$ ao ano sobre o investimento reconhecido, acarretou uma "ênfase na área de construção de novos sistemas em detrimento do setor de operações, que não era financiado pelo BNH", o que "levou a uma posterior degradação dos sistemas e a um índice bastante elevado de perdas de água”. (TUROLLA, 2007, p. 200)

A política tarifária pretensamente realista e almejada pelo Planasa, a incluir as parcelas destinadas a cobrir todos os custos de manutenção e operação dos sistemas, além dos custos financeiros dos empréstimos, foi, com o tempo, minada pelas contradições dos gestores do sistema.

Os reajustes tarifários adotados pelo Governo Federal não contemplavam as necessidades plenas do setor. Os retornos obtidos pelas empresas de saneamento não eram suficientes para realimentar o sistema.

A década de 1980 testemunhou o significativo enfraquecimento do modelo Planasa. Sua higidez financeira foi abalada pela insuficiência tarifária, pela escassez de recursos, pelas as crescentes restrições fiscais, pelo contexto econômico de forte inflação e em razão do fim dos prazos de carência dos empréstimos realizados anteriormente em favor das empresas estaduais. Na síntese sempre pertinente de Motta (2007, p.178):

\begin{abstract}
A queda de dinamismo do setor deve-se, em grande parte, às rígidas restrições fiscais dos últimos anos, quando escassearam os recursos públicos. Entretanto, o setor já vinha demonstrando perda de capacidade de financiamento desde os anos 1980, quando as empresas públicas estaduais não conseguiram adaptar suas formas de gestão ante a deterioração da sua capacidade financeira por conta dos processos inflacionários.
\end{abstract}

Nos anos seguintes ao Plano Real, as empresas tentaram retomar essa capacidade e o realismo tarifário, mas fracassaram ao manter suas desgastadas e viciadas práticas de gestão associadas a uma ausência de marco regulatório que introduzisse incentivos à eficiência. Paralelamente, o setor privado também não encontrava sinais regulatórios claros e estáveis para se expandir, e sua participação hoje não ultrapassa $4 \%$ da cobertura total do país, estando toda concentrada nas concessões municipais. ${ }^{12}$

\footnotetext{
${ }^{12}$ No mesmo sentido informa Turolla (2007, p. 200): "Na década de 1980, o Planasa já evidenciava avanços na cobertura das redes de água e de esgoto, ainda que distante da universalização. Entretanto, já naquele momento vários fatores contribuíram para a deterioração da saúde financeira das companhias. As fontes de financiamento esgotaram-se acompanhando as dificuldades macroeconômicas, ao mesmo tempo em que terminavam as carências dos empréstimos obtidos nos anos anteriores e aumentavam as despesas de amortizações e encargos financeiros das dívidas. A ênfase anterior em construção, o uso político das
} 
A ausência de mudanças estruturais relevantes no setor durante a década de 1990 foi contrabalanceada pela disciplina relativa às concessões de serviço público, em atenção ao disposto no art. 175 da Constituição da República, o que, em tese, incentivaria a participação do setor privado na prestação dos serviços.

Entretanto, tendo em vista que a proposta de criação de um marco legal próprio para o saneamento veio à tona somente em 2007, o longo período de incerteza regulatória resultou em uma reduzida atuação de empresas particulares que, há poucos anos, compunham apenas 4\% do mercado em consideração. (TUROLLA, 2007, p. 203)

De fato, o período referente ao Planasa foi marcado pela proliferação de mecanismos de estabelecimento de preços permeados pela unilateralidade, associados a instrumentos contratuais de caráter precário, dependentes de uma política de subsídios cruzados geradora de incerteza a respeito dos custos das atividades.

Como se vê, o Planasa apresentou varias consequências. Houve inegável aumento na prestação dos serviços, especialmente a distribuição de água. De outro lado, criou-se uma estrutura na qual os Municípios tinham pouca ou nenhuma voz ativa e as empresas do setor privado obtiveram pouco incentivo para sua atuação.

Em outra perspectiva, as premissas do Planasa não permitiram que a maioria dos Municípios que a elas aderiram, especialmente os de menor porte, desenvolvesse condições próprias para a assunção das responsabilidades inerentes às atividades de saneamento. Tais Municípios pouco decidiam a respeito do funcionamento dos serviços, seja no que toca à sua operação, seja no que concerne aos modelos tarifários utilizados.

Durante todo o período avaliado, houve, portanto, marcante preponderância das determinações federais e estaduais a respeito do saneamento e do seu funcionamento.

A experiência histórica do saneamento é um retrato fidedigno da dinâmica do Estado Federal brasileiro em que a União, em primeiro lugar, e posteriormente os Estados, por deterem o controle da maior parte das receitas públicas, acabam retendo elevada ingerência nas políticas públicas de interesse local.

Ocorre que o regime adotado pela Constituição de 1988 solidificou, conforme será abordado adiante, a titularidade dos serviços públicos locais pelos entes municipais,

companhias e o crescimento da inflação impuseram um ônus adicional sobre os custos de operação. Há relatos de pressão por controle das tarifas das companhias estaduais a partir de objetivos da política macroeconômica, notadamente no que se refere a tentativas de controle da inflação, sem levar em conta as conseqüências microeconômicas dessa prática". 
neles incluídos, em muitos aspectos, o saneamento (em que pese a existência de discussões judiciais a respeito da titularidade, devidamente estudadas no decorrer do trabalho).

A Constituição Federal de 1988 rompeu, assim, ao menos no papel, com a centralização dos serviços criada durante o regime militar.

Nesse contexto, a contradição entre o comando jurídico contido na Constituição, que atribui aos Municípios a prerrogativa para gestão dos serviços de interesse local, e a dura realidade econômica e gerencial de parte significativa dessas unidades federadas dá natural relevo a mecanismos que promovam o apoio e o intercâmbio institucional entre os entes da federação.

É preciso ter em mente que, em algumas situações, a gestão local do saneamento será perfeitamente cabível e possível. Admitir-se-á até a hipótese em que o tamanho e a força econômica do Município, associados a técnicas mais eficientes de prestação dos serviços, possam resultar em tarifas módicas e capazes de manter a sustentabilidade do empreendimento.

Em outras palavras, soluções locais para a gestão do saneamento poderão ser sempre cogitadas, sendo possível afirmar a existência de casos de sucesso que envolvam a gestão por um único Município. Os serviços autônomos de água e esgoto se encontram presentes em diversos Municípios, apresentando-se, em muitas hipóteses, como uma opção eficiente de operação. Somente a análise de cada caso concreto indicará as melhores condições de implantação de serviços públicos.

Em outros casos, questões naturais, como a ausência de fontes locais de captação de água ou de região para depósito de resíduos, cumuladas ou não com a baixa capacidade econômica da população e as dificuldades de gestão inerentes a Municípios de pequeno porte resultarão no imperativo de conjugação de forças para prestação das utilidades públicas representadas pelo saneamento básico.

Assim, a gestão compartilhada será uma alternativa viável nas circunstâncias em que a escala dos serviços represente uma condição importante para sua viabilidade econômica ou física ou quando limitações administrativas favorecerem a união de entes federados.

Nesse contexto, a gestão compartilhada se apresenta como uma alternativa interessante que pode, ao mesmo tempo em que remodela muitos dos aspectos da gestão do setor, preservar aquilo que talvez seja a maior contribuição do Planasa, qual seja, a 
necessidade e o reconhecimento de que a interação entre entes federados para consecução dos serviços é sempre uma medida bem-vinda.

Contudo, a simples demonstração dos contornos jurídicos da gestão compartilhada não assegura seu sucesso como instrumento de gestão de serviços públicos.

Não será esse o momento para delinear os principais aspectos da gestão compartilhada. Cabe apenas, com base na experiência histórica do saneamento, frisar que o desafio de sua universalização não pode repetir os equívocos do Planasa: a centralização de políticas públicas nas esferas federal e estadual; a contaminação do sistema por práticas clientelistas e contraproducentes que envolvam tarifação inadequada e insustentável; a baixa participação do Município e de sua população na gestão dos serviços e a imposição vertical de políticas e padrões de operação, acarretando reduzida transferência de conhecimento técnico a respeito dos sistemas.

A interação entre os entes federados deve ocorrer agora sob renovada faceta, capaz de dar concretude ao comando constitucional que traça a responsabilidade dos Municípios pelos serviços locais, assegurando a capacidade da unidade federada municipal de, efetivamente, direcionar as políticas públicas do saneamento.

Desse modo, a gestão compartilhada será norteada pela necessidade de que o titular dos serviços tenha real ingerência sobre seu funcionamento. Trata-se de compreender o federalismo como uma arena para a cooperação, e não para definição unilateral de políticas públicas pelas unidades federadas que controlam o grosso das receitas públicas.

\subsection{O ENQUADRAMENTO TIPOLÓGICO DOS SERVIÇOS DE SANEAMENTO BÁSICO NO BRASIL}

A adequada compreensão dos aspectos evolutivos da gestão do saneamento básico remete, necessariamente, à discussão em torno da classificação do saneamento como espécie de serviço público. 
A discussão não é simplesmente teórica. Com base na dimensão conceitual do saneamento será possível traçar suas principais formas de organização em consonância com as regras da gestão compartilhada.

Não é objetivo, aqui, traçar uma linha evolutiva do conceito de serviço público, o qual, como se sabe, vem ultrapassando diversas fases históricas, assumindo em cada uma delas feições próprias e cambiáveis sob o influxo das vicissitudes sociais. ${ }^{13}$

${ }^{13}$ Com efeito, o mergulho no tema dos serviços públicos com intenção de evidenciar seu passado e prospectar sua evolução pode representar um desejo que, se já não nasce frustrado, corre risco sério de se deparar com um sem-número de caminhos e possibilidades que, em essência, não indicam o rumo certo a trilhar. No máximo, uma sensação de direção que, com sorte, resultará em uma margem de acerto maior ou menor. Explorado por inúmeros precursores, o passeio por essas águas, ora turvas, ora mais claras, mostra uma paisagem muito vista e comentada, e, ainda assim, nunca objeto de unanimidade quanto aos seus contornos e medidas. Ao contrário, se existe um ponto pacífico no que toca ao serviço público, diz respeito à mutabilidade do conceito e de suas características materiais. Desse modo, tem razão Reigada (1999, p. 100) quando afirma que, mesmo em suas origens, não há uma uniformidade doutrinária a respeito do serviço público. Segundo nos diz o autor em referência, De ahí que no haya habido una uniformidad doctrinal acerca de lo que significaba el concepto de servicio público, ni siquiera en sus orígenes. A pesar de que se ha hablado en Francia de unos princípios estrechamente vinculados a la idea misma de servicio publico - 'de unas leyes naturales del servicio público', no es idêntica la noción de servicio público de Hariou y de Duguit. Mientras el primero vinculaba esta categoría a la titularidad pública de la actividad, Duguit tenía una idea amplia del servicio público, apoyada sobre unas actividades consideradas de utilidad pública. La idea dominante, el denominador común en la noción amplia de servicio público era el interes general. Mientras que para Hauriou existían actividades que por naturaleza son propias de la Administración - concepción objetiva -,Duguit rechaza esta perspectiva afirmando que la aparición de un servicio público parte de una decisión previa discrecional y subjetiva de los gobernantes de establecerlo. (REIGADA, 1999, p. 100)

Do ponto de vista teórico, o problema de trabalhar com uma paisagem já visitada e glosada por muitos é óbvio: há um grande número de posições e opiniões para consideração, muitas vezes, contraditórias e incompatíveis. Tentar encontrar uma unidade absoluta na doutrina sobre o serviço público se revelaria, assim, uma atividade estéril.

A hiperinflação doutrinária não deve ser encarada como algum ruim a priori. As contribuições doutrinárias podem, efetivamente, auxiliar na compreensão da evolução do Direito, por meio de sua pretensão de sistematização e organização da realidade.

O grande obstáculo se revela quando as considerações da doutrina se sobrepujam à realidade que constitui seu objeto. Tratando-se de serviços públicos, o aviso se reveste de pertinência maior. A mutabilidade do instituto exige uma atenção redobrada às alterações jurídico-sociais que são o objeto de estudo da dogmática jurídica.

Nesse cenário, o fantasma da repetição de velhas fórmulas encontra-se sempre presente e pode anuviar uma abordagem que deveria ser mais atenta à realidade cambiável das relações que conformam o serviço público.

É interessante notar que a discussão em pauta não é restrita ao ambiente jurídico brasileiro. Reigada (1999) nos informa a respeito do amplo debate que ocorre no cenário espanhol sobre a necessidade da dogmática como método de investigação jurídica. De um lado as opiniões como a de Villar Palasí, citado por Reigada, que critica o sofisma da categorização excessiva que produziria estragos na doutrina administrativa espanhola. De outro, autores de peso, como García de Enterría (1998 apud REIGADA, 1999, p. 95-96), destacam a necessidade da dogmática como capacidad de construir un entramado institucional complejo, ordenándolo alrededor de unos cuantos vectores arraigados en la naturaleza profunda de la institución de que se trata y dirigiendo toda la operación en función de unos valores jurídicos materiales que están presentes en dicha institución. Para Enterría solo la dogmática es capaz de alumbrar los elementos estructurales profundos de las instituciones y sua articulación en servicio de los princípios generales del Derecho que sostienen y animan a dichas instituciones para que alcancen su mayor funcionalidad. 
A complexidade do tema deriva do fato de que as concepções a respeito dos serviços públicos e as imbricações que apresentam atingem quase sempre esferas exteriores à ordem jurídica. Salomoni ensina que a referência aos serviços públicos traz, em primeiro lugar, uma profunda conexão com uma teoria do Estado e, juntamente com ela: "uma teoria do poder em quanto suas formas e fundamentos (legitimidade do poder); os elementos constitutivos do Estado; as formas de Estado: que incluem a questão do Estado máximo e do Estado mínimo; a continuidade do Estado”. (SALOMONI, 1999, p. 325)

Em uma segunda perspectiva, o serviço público diz com a intervenção do Estado na economia, e sua qualificação como: "técnica de sujeição dos fatores produtivos privados à planificação estatal; técnica de regulação de mercados e técnica de distribuição de bens e serviçoo". (SALOMONI, 1999, p. 325-326)

Por último, é o serviço público uma técnica de garantia dos direitos humanos, cujos desdobramentos seriam sua consideração como: "técnica de equiparação do disfrute de bens materiais e culturais produzidos em uma sociedade e para todos os indivíduos que a compõem; técnica de igualdade de tratamento jurídico e político e técnica de integração social”. (SALOMONI, 1999, p. 327)

Nem mesmo se pretende tratar à exaustão as diferentes classificações dos serviços públicos, já que as atividades classificadas são, a toda evidência, múltiplas, díspares em suas características e métodos de implantação. ${ }^{14}$

O desafio presente neste tópico é, portanto, o de bem conceituar o saneamento como figura jurídica dotada de caracteres próprios que certamente influenciarão nas opções que serão realizadas para sua gestão.

\footnotetext{
A função didática e sistematizadora da dogmática não pode ser menosprezada. A ela cabe encontrar a coerência em contextos normativos aparentemente contraditórios. Diante de uma realidade complexa e variada, deve ser capaz de renovar-se e renunciar a velhas categorias. Nesse percurso, provavelmente, abandonará conceitos gerais não mais aplicáveis a uma realidade fracionada: En muchas ocasiones, la dogmática tiene que asumir su incapacidad de elaborar categorías, que sean generales y que acierten a explicar uma realidad compleja y variada. El abandono de lo general no debe ser visto como una huida sino que es casi siempre una imposición de la realidad social, al igual que el abandono de lo permanente es una consecuencia de la propria realidad y de la voluntad del legislador. Por eso, la actitud hacia la dogmática, aun asumiendo su carácter de método juídico válido, tiene que ser profundamente desmitificadora. (REIGADA, 1999, p. 96-97)

${ }^{14}$ Justen Filho (2004, p. 164) evidencia essa circunstância ao tratar das inovações no serviço público: "Outra inovação é a extinção da uniformidade de regime jurídico. Torna-se impossível aludir a 'o serviço público', em virtude da afirmação de uma multiplicidade de serviços públicos, cada qual com regime jurídico diferenciado. Surge o direito das telecomunicações, o direito de energia elétrica, o direito da educação e assim por diante."
} 
Daí a busca pelo posicionamento conceitual do saneamento em categoria jurídica que permita a compreensão do verdadeiro cerne do trabalho: a gestão compartilhada de serviços públicos.

Em suma, importará o estabelecimento de premissas que permitam encarar o saneamento como unidade de significado em meio às inúmeras manifestações da prestação de serviços pelo Estado.

\subsubsection{Uma aproximação conceitual acerca dos serviços públicos}

De início, reconhece-se a existência de inúmeras controvérsias a respeito da indicação dos elementos mínimos e comuns que possam individualizar a noção dos serviços públicos. Aqueles que se propõem a descrever as inúmeras posições a respeito do tema têm a nítida impressão de que se trata de uma ação inacabada, sempre sequiosa de novos aprofundamentos.

Di Pietro (2008a, p. 92) leciona que, nas origens ${ }^{15}$ do instituto em apreço, os autores se valiam dos critérios subjetivo (desempenho da atividade pelo Estado), material (o serviço público como atividade que satisfaz necessidades coletivas) e formal (submissão ao regime jurídico de direito público, exorbitante do direito comum) para a caracterização dos serviços públicos.

A evolução dos métodos de gestão e implantação da ação administrativa levou, inevitavelmente, à reformulação do conteúdo de tais critérios, em busca da superação das sucessivas crises pelas quais passou a noção do serviço público. ${ }^{16}$

\footnotetext{
${ }^{15}$ Seria inviável precisar o momento e o local em que surge a noção de serviço público pela primeira vez. Dificulta essa análise o fato de que em muitos países a prestação de serviços essenciais pelo Estado é um fato assimilado de forma peculiar pelos respectivos ordenamentos jurídicos.

${ }^{16}$ Perez (2006, p. 27) esclarece que a definição clássica dos serviços públicos (que remete aos primórdios do instituto quando era identificado com toda e qualquer atividade administrativa), embora tenha passado por sucessivas evoluções, teve papel relevante na estruturação do Direito Administrativo: "Pode-se, então, concluir, resumida e topicamente, que a função cumprida pela definição clássica de serviço público, no plano da estruturação do Direito Administrativo, revela-se por diferentes prismas. Primeiramente, é a partir dessa definição clássica que se fundamentou o regime jurídico especial - derrogatório do direito comum - que dá essência ao Direito Administrativo. Em segundo lugar, foi dessa definição que nasceu a noção de finalidade da ação administrativa e, conseqüentemente, do Direito Administrativo ou, como preferem alguns, de legitimação do Direito Administrativo. Em terceiro lugar, essa definição cumpriu um papel um papel muito útil ao desenvolvimento do chamado estado de bem estar social, ao servir, como já dissemos, de combustível à expansão da intervenção do Estado na vida social, propiciando a atuação do
} 
Nesse contexto, para Di Pietro (2008a, p. 94), os três elementos que compõem a definição do serviço público (subjetivo, formal e material) remanescem como balizas para a compreensão do instituto, observadas as diferenças significativas em relação à sua concepção.

O aspecto subjetivo leva em consideração o fato de que os serviços atribuídos ao Poder Público pela lei podem ser executados tanto diretamente pelo Estado quanto de forma indireta ou descentralizada, abrangendo pessoas jurídicas criadas para essa finalidade ou por meio de institutos como a concessão ou permissão (ou seja, há um dever de prestação, definido pela lei, ${ }^{17}$ ainda que alguns serviços sejam abertos à iniciativa privada como no caso da educação e da saúde).

Para muitos autores, o aspecto subjetivo representa um elemento inafastável da noção de serviços públicos. Um fator distintivo que, ausente, levaria a uma ampliação demasiada do conceito, a abarcar atividades privadas que, apesar de dotadas de um inegável conteúdo público, não são passíveis de qualificação como serviço público.

Gonçalves (1999, p. 35-36) reforça esse entendimento ao ver o serviço público como uma atividade pública em sentido subjetivo:

O ponto de partida que adoptamos é abertamente subjectivo. Isto é, para nós, o serviço público é uma actividade pública.

A sustentação da tese subjectivista implica a recusa da aplicação do conceito de serviço público às actividades do sector privado por cuja existência e resultados a Administração é responsável.

\footnotetext{
Estado na defesa da solidariedade e da coesão social, toda a vez em que o mercado apresentasse falhas que o justificassem. Por fim, a definição clássica fundamentou a criação de empresas estatais monopolistas e a obrigação estatal de implantação das redes e infra-estruturas necessárias para prestação de serviços públicos".

${ }^{17}$ A atribuição expressa do serviço ao Estado é um critério identificador do serviço público presente desde as fontes mais remotas do instituto. Decorre da antiga e hoje questionada separação Estado/Sociedade. Com base em transcrição de Ariño Ortiz, Dinorá Grotti (2003, p. 41) informa que "o mecanismo ideológico (separação Estado/Sociedade) reclama que, se há uma separação entre tarefas do Estado e tarefas da Sociedade, para intervir em um certo campo o Estado necessita previamente declará-lo de sua competência, quer dizer, declará-lo público". Adiante, arremata a autora afirmando que "serviço público e publicatio (passagem à titularidade do Estado) aparecem assim na cultura jurídica européia de raiz francesa indissoluvelmente ligados, diferentemente do que sucederá nos países anglo-saxões”. Contudo, a apreciação isolada do critério subjetivo pouco significa. Grau bem assevera que (2008, p. 126) "a mera atribuição de determinada atinente à prestação de serviços ao Estado não é suficiente para definir essa prestação como serviço público. Cumpre verificar, sempre, quando isso ocorra, se a atribuição constitucional do serviço de determinada competência ao Estado atende a imposições de interesse do trabalho, no seu confronto com interesses do capital, ou se, pelo contrário, outras razões determinaram a atribuição desse exercício pelo Estado.” Exemplifica o autor com a hipótese do inciso XXIII do art. 21 da Constituição (explorar serviços e instalações nucleares de qualquer natureza) que para ele constitui atividade econômica em sentido estrito e não serviço público.
} 
Sendo certo que tais actividades privadas de interesse público ou geral estão num degrau ou categoria intermediária, visto que está nelas implicada uma responsabilidade administrativa (responsabilidade-garantia), a verdade é que se trata de actividades privadas que, na maior parte dos casos, foram objecto de um processo de privatização.

Manter o conceito de serviço público (objectivo) para caracterizar as actividades privadas que nascem desse processo só pode explicar-se como uma tentativa desesperada de manter viva uma idéia que o 'désengagement' do Estado quis pôr abertamente em causa.

O processo de privatização material dos serviços públicos é, portanto, a base que nos permite considerar de serviço público apenas certas tarefas de cuja execução a Administração continua a estar incumbida (tarefas materialmente públicas).

Embora não se exclua o conceito de actividades privadas sujeitas a um regime jurídico próximo de um regime de serviço público, recusa-se o conceito de serviço público objectivo, que, de resto, nunca teve acolhimento na doutrina portuguesa.

Na nossa opinião, o serviço público, enquanto tarefa ou actividade, refere-se, portanto, a uma tarefa administrativa, a uma actividade de que a Administração é titular e por cujo exercício é responsável (responsabilidade de execução).

No que toca ao elemento formal, que concerne ao regime jurídico dos serviços, ao invés do predomínio absoluto de regras de direito público, tem-se aberta a convivência de normas públicas e privadas, um regime híbrido, com a prevalência alternada de um ou outro tipo de regras a depender da atividade em consideração. ${ }^{18}$

$\mathrm{O}$ elemento material continua a significar que a atividade qualificada como serviço público visa ao atendimento do interesse coletivo, de necessidades básicas dos cidadãos (na forma como determinada pela lei), diferenciando-se de outras atividades administrativas como o fomento e a polícia administrativa pelo seu caráter prestacional e positivo.

Nesse ponto, há muito se encontra sedimentada a possibilidade que, dentre as atividades qualificadas como serviço público, figurem aquelas com forte viés econômico que poderiam ser facilmente relegadas ao setor privado não fosse o dever de prestação e a titularidade exclusiva (em alguns casos) do Estado lavrados nos diplomas legais.

Realizadas tais ponderações, surge com maior precisão uma noção geral de serviço público. Di Pietro (2008a, p. 94) leciona que o serviço público é "toda atividade material que a lei atribui ao Estado para que exerça diretamente ou por meio de seus

${ }^{18}$ É exemplar o caso dos serviços de telecomunicações que comportam serviços prestados no regime público (pautado por obrigações de universalidade e continuidade) e regime privado, submetido a regulação consideravelmente mais leve. 
delegados, com o objetivo de satisfazer concretamente às necessidades coletivas, sob regime jurídico total ou parcialmente público".

Vistos dessa forma, os critérios indicados se prestam à conformação de um quadro geral a respeito da caracterização dos serviços públicos, muito útil para uma primeira aproximação em relação ao instituto, mas que não elimina a imprescindível atenção às peculiaridades de cada setor. Com efeito, atualmente, a abordagem dos serviços públicos deve ser realizada em sucessivas camadas, das mais amplas, que oferecem uma visão geral dos fundamentos do instituto, àquelas que permitam o exame das particularidades de cada atividade.

Em algumas situações o quadro geral delineado pode não corresponder exatamente à realidade de determinado serviço ou atividade, demandando do estudioso o esforço adaptativo e investigativo para compreensão dos fatos que lhes são apresentados. Outras hipóteses demonstrarão que a utilização isolada dos critérios destacados de nada adiantará.

Saliente-se que para muitos a utilização de uma categoria ampla como a do serviço público perdeu o sentido:

Os fenômenos da reestruturação dos serviços de titularidade estatal (energia,
telecomunicações, saneamento, transportes, etc.) está produzindo uma
importante alteração do Direito Administrativo, cujos modelos teóricos devem,
em grande medida, ser reinventados. Durante bom período o conceito de serviço
público serviu para razoavelmente sintetizar o regime jurídico da exploração
dessas diversas atividades. É bem verdade que essa noção veio se modificando
no tempo, tornando-se pouco a pouco muito problemática; além disso, por ter
sido usada para englobar serviços os mais distintos, com as respectivas
especificidades, seu conteúdo jamais foi suficiente para dar conta dos problemas
e características particulares de cada um deles. Tratava-se, todavia, de noção útil.
Hoje não o é mais, ao menos da mesma forma que antes. (SUNDFELD, 2002, p.
32)

Entende-se como pertinente o aviso dado por Sundfeld, o qual, todavia, não torna inválido o esforço de perscrutar elementos que, ainda que genéricos, permitam uma compreensão por aproximações do serviço público.

Se é certo que uma noção geral e perfeita de serviço público, capaz de congregar e subsumir todas as hipóteses concretas, é inviável, a construção de linhas gerais que situem minimamente o operador do direito perante o seu objeto de trabalho também possui seus méritos, uma vez que provê um pano de fundo que tornará mais palpáveis as distinções e desdobramentos internos do conceito ou, mesmo, indicará com maior 
segurança a exclusão do âmbito de influência do instituto de setores ou atividades que nele não mais se enquadrem.

Ao lado desse quadro doutrinário genérico, que pode comportar especificações e até mesmo exceções, deve-se manter presente a ideia de que o sistema normativo comporta subsistemas jurídicos "parcelas do ordenamento jurídico pautadas por princípios, conceitos e estruturas hierárquicas próprios a determinado setor". (MARQUES NETO, 2002b, p. 301)

Deve-se lembrar que a prospecção dos contornos gerais da noção de serviço público, ora empreendida, tem um significado instrumental. Destina-se à categorização dos serviços de saneamento no âmbito da multiplicidade das atividades administrativas.

Não será possível atingir tal objetivo sem um exame das principais determinações do ordenamento jurídico brasileiro sobre o tema.

Considerando-se o nosso sistema jurídico, a construção das premissas que levarão às conclusões buscadas deve-se iniciar pela compreensão do disposto no Texto Constitucional. ${ }^{19}$

Inicialmente, esse exame deve ser empreendido em dois níveis: (i) o tratamento do serviço público na Constituição como categoria geral e abstrata e as (ii) manifestações constitucionais a respeito do saneamento.

Marques Neto (2004, p. 332-333) vê no ordenamento pátrio duas acepções distintas de serviço público, refletidas cada qual nos arts. 145, II, e 175 da Constituição de 1988. No primeiro caso, uma acepção lata, sinônimo de função pública, a situar o serviço público como fato gerador do lançamento da taxa. Já na segunda situação (prevista no art. 175), reconhece o autor o serviço público como espécie do gênero atividade econômica. A nota primordial dos serviços públicos como espécie de atividade econômica reside na possibilidade de sua exploração econômica sem que sua essência seja desnaturada.

\footnotetext{
${ }^{19}$ A descrição do tratamento constitucional dada aos serviços de saneamento básico exercerá, também, a função de ponto de partida para discussões mais complexas que envolvam, por exemplo, a titularidade dos serviços quando da sua prestação compartilhada. Ademais, sem o conhecimento prévio do posicionamento constitucional do saneamento, restará difícil, senão improvável, avaliar os desdobramentos que a prestação compartilhada oferece. Com efeito, no decorrer do trabalho se verificará que a prestação compartilhada mostra-se viável justamente em razão de instrumentos e institutos que, com sede no Texto Constitucional, proporcionam um redesenho das competências originárias a respeito da prestação de serviços públicos (consórcios públicos, convênios de cooperação e regiões metropolitanas). Desse modo, uma compreensão plena do desenho de competências constitucionais é pressuposto para o estudo da possibilidade de delegação dessas competências entre os entes federados.
} 
No âmbito dos serviços públicos econômicos, insere o autor aqueles

que são delegáveis por opção do poder público (aqueles arrolados, por exemplo, no art. 21 da Constituição) nos termos do artigo 175; aqueles que devem ser objeto de delegação ao menos parcial, à iniciativa privada (os serviços de radiodifusão sonora e de sons e imagens, conforme o art. 223); e aqueles para os quais se admite a participação da iniciativa privada em caráter complementar (serviços de saúde em caráter complementar no âmbito do SUS) ou suplementar (serviços de saúde explorados livremente pela iniciativa privada, fora do SUS, conferir art. 199, caput, CF; serviços de educação, cf. art. 209, CF). (MARQUES, 2004, p. 134)

Aragão (2007, p. 144) atesta a existência de diversas gradações a respeito da noção do serviço público na Constituição de 1988, a qual, segundo o autor "não chega a ser precisa na utilização da nomenclatura, ora se referindo a serviços públicos em sentido apenas econômico, como atividades de titularidade do Estado que podem dar lucro (ex.: arts. 145, II e 175), ora como sinônimo de Administração Pública (ex.: art. 37), ora para tratar do serviço de saúde prestado pelo Estado (ex.: art. 198). Outras vezes se refere apenas a "serviços" (ex.: art. 21) e "serviços de relevância pública" (ex.: arts. 121 e 197).,"20

Com base nessa constatação, Aragão (2007, p. 144-149) afirma que a Constituição brasileira abarca uma variada gama de concepções doutrinárias a respeito dos serviços públicos:

\footnotetext{
${ }^{20}$ Em sentido semelhante nos ensina Grotti (2003, p. 89): “A expressão surgiu pela primeira vez em nossos textos constitucionais pátrios com a Carta de 1934, não tendo sido, desde então, erigido algum conceito constitucional de serviço público. O texto de 1988 fornece alguns parâmetros, alguns referenciais conformadores da área definida como própria dos serviços públicos.

Na Constituição Federal atual dois critérios são frequentemente atribuíveis a tal expressão: o sentido orgânico ou subjetivo, com significado de aparato administrativo do Estado (arts. 37, XIII; 39, § $7^{\circ} ; 40$, III, 40, § 16, 136, § $1^{\circ}$, II; ADCT, art. $2^{\circ}, \S 1^{\circ}$; art. $8^{\circ}$, $\S 4^{\circ}$; 19 e 53) e o objetivo, significando uma modalidade de atividade de natureza pública (arts. $21, \mathrm{X}, \mathrm{XI}, \mathrm{XII}, \mathrm{XIV} ; 30, \mathrm{~V} ; 37, \S 6^{\circ} ; 54$, I, 'a'; 61, § $1^{\circ}$, II, 'b', 139, VI; 145, II; 175; 198; 202, § 5; 223; 241; ADCT, art. 66).

A amostra é bem expressiva de que a Constituição Brasileira acolhe a categoria de serviço público, e de que inspira a atuação do Poder Público também na idéia de prestação de um sistema de serviços. Trata-se de atividades de titularidade do Poder Público, que não se desnaturam quando sua execução é delegada a particulares, pois a Constituição fixa um vínculo orgânico com a Administração, ao dispor, no caput do art. 175, que incumbe ao Poder Público a prestação de serviços públicos, diretamente ou sob regime de concessão ou permissão".
} 
(i) uma concepção amplíssima, que pode ser identificada com a escola do serviço público de León Duguit e equivalendo a todas as atividades estatais ou a um sinônimo de Administração Pública (critério orgânico ou subjetivo); ${ }^{21}$

(ii) uma concepção ampla dos serviços públicos, que corresponderia às atividades prestacionais em geral do Estado. Funções exercidas para prestação de comodidades ou utilidades a despeito de contrapartida pecuniária do usuário ou da titularidade exclusiva da atividade por parte do Estado, a abarcar: serviços públicos econômicos (remuneráveis por taxa ou tarifa), serviços sociais (que podem ser prestados por particulares sem necessidade de delegação) e serviços uti universi, não específicos, indivísiveis e sem beneficiários individualizáveis (segurança pública, por exemplo). Ressalta o autor que, nesse caso, ficariam de fora da concepção apenas o poder de polícia administrativa e a atividade de fomento;

${ }^{21}$ As noções demasiadamente abrangentes sobre o serviço público, que costumam associá-los a toda e qualquer atividade estatal, carecem de funcionalidade operacional. Sua extensão exacerbada dificulta a delimitação precisa dos principais elementos constitutivos dos serviços.

$\mathrm{Na}$ França, país cujo sistema jurídico-administrativo influenciou fortemente a experiência brasileira, a construção da noção do serviço público pretendia atender às necessidades de sistematização de um Direito Administrativo em franca transformação, que testemunhava a presença cada vez maior do Estado em atividades antes atribuídas apenas à iniciativa privada. Havia, a rigor, uma motivação prática e científica no desenvolvimento da noção de serviço público: buscava-se, diante de crescimento da atividade administrativa, um critério delimitador das fronteiras entre a jurisdição administrativa e a comum, bem como a obtenção dos fundamentos do sistema jurídico-administrativo em função dos novos desafios que enfrentava.

A respeito do trabalho de mestres como Duguit e Jèze, convém recuperar seus principais acertos e equívocos. De Duguit extraímos a importante lição, válida até os dias de hoje, de que a noção de serviço público encontra-se assentada sob uma concepção de solidariedade e interdependência social. O Estado assume certas atividades em razão de sua importância para a manutenção da coesão social. Para o autor, a escolha e o tratamento de uma atividade como serviço público não resultam de mero voluntarismo do Poder Público, mas são fruto da verdadeira força criadora do Direito, que é o "estado de consciência da massa dos indivíduos que compõem em um determinado grupo social”. (ARAGÃO, 2007, p. 82)

Buscava Duguit, diante das profundas transformações pelas quais vinha passando a sociedade europeia do início do século XX, em especial a crescente participação do Estado no fornecimento de utilidades públicas, a reformulação dos fundamentos do Direito Público, que deveria encontrar suas bases no caráter prestacional da ação pública em detrimento da noção pura de soberania ou autoridade (puissance).

As elevadas pretensões de Duguit resultaram, contudo, em uma teoria de contornos excessivamente amplos. Grotti (2003, p. 33) bem sintetiza o fato de que em Duguit, a noção de serviço público é mais sociológica do que jurídica, pois não fornece o autor elementos para a caracterização da figura perante o direito.

Ao tentar transformar o serviço público na pedra angular do Direito Administrativo, Duguit provocou a supervalorização dessa noção, que passou a abarcar toda e qualquer atividade estatal, a ponto de perder qualquer funcionalidade prática.

Tentando justamente combater o sociologismo de Duguit e a fim de oferecer critérios mais objetivos para o tratamento do tema, Jèze acrescenta ao mural da teorização do serviço público a importância do regime jurídico de Direito Público para sua caracterização. Serviço público é a atividade prestada pelo Estado nos termos de um regime jurídico especial de Direito Público. Ainda assim tal concepção padecia dos mesmos problemas de amplitude elevada que marcaram a tese duguista. 
(iii) uma concepção restrita de serviço público que corresponderia apenas às atividades prestacionais que tivessem um liame imediato com os indivíduos (usuários identificáveis e fruição quantificável do serviço). Nesse caso, ficariam excluídos os serviços uti universi e incluídos os serviços públicos econômicos e sociais (lembre-se que dentre os últimos se enquadram aqueles que, por não serem de titularidade exclusiva do Estado, carecem de necessidade de delegação prévia para seu exercício pela iniciativa privada);

(iv) uma concepção restritíssima de serviço público, decorrente dos arts. 145, II, ${ }^{22}$ e $175^{23}$ da Constituição. Trata-se dos serviços remunerados por taxa e tarifa, de titularidade exclusiva do Estado, exploráveis pela iniciativa privada por meio de concessão e permissão. Nesse caso, ficariam excluídos dos serviços uti universi e os serviços sociais abertos à iniciativa privada.

Ainda seguindo a linha de raciocínio de Aragão (2007, p. 157), a concepção dita restrita do serviço público seria a mais operacional, por congregar um conjunto de atividades (serviços econômicos e sociais nos quais é possível qualificar individualmente os usuários e a respectiva fruição) que compartilham elementos comuns capazes de lhes conferir uma unidade de sentido.

Nesse contexto, o autor qualifica os serviços públicos como as "atividades de prestação de utilidades econômicas a indivíduos determinados, colocadas pela Constituição ou pela Lei a cargo do Estado, com ou sem reserva de titularidade, e por ele desempenhadas diretamente ou por seus delegatários, gratuita ou remuneradamente, com vistas ao bem-estar da coletividade”. (ARAGÃO, 2007, p.157)

Em um esforço de decomposição do conceito proposto, Aragão (2007, p. 158163) evidencia as principais características dos serviços públicos segundo seu entendimento: ( $i$ ) o caráter prestacional da atividade, em contraposição a atividades que

${ }^{22}$ Nos termos do citado dispositivo: “Art. 145. A União, os Estados, o Distrito Federal e os Municípios poderão instituir os seguintes tributos: [...] II - taxas, em razão do exercício do poder de polícia ou pela utilização, efetiva ou potencial, de serviços públicos específicos e divisíveis, prestados ao contribuinte ou postos a sua disposição; [...]."

${ }^{23}$ Nos termos do citado dispositivo: "Art. 175. Incumbe ao Poder Público, na forma da lei, diretamente ou sob regime de concessão ou permissão, sempre através de licitação, a prestação de serviços públicos. Parágrafo único. A lei disporá sobre: I - o regime das empresas concessionárias e permissionárias de serviços públicos, o caráter especial de seu contrato e de sua prorrogação, bem como as condições de caducidade, fiscalização e rescisão da concessão ou permissão; II - os direitos dos usuários; III - política tarifária; IV - a obrigação de manter serviço adequado." 
restringem a esfera jurídica dos indivíduos, como o poder de polícia; (ii) a natureza econômica das atividades que constituem os serviços públicos; (iii) o direcionamento dos serviços ao atendimento de necessidades de indivíduos determinados, excluídos, portanto, os serviços uti universi; (iv) a necessidade do fundamento constitucional ou legal para configuração de uma atividade como serviço público; $(v)$ a atribuição do serviço à responsabilidade do Estado, com ou sem reserva de titularidade, permitida, em muitos casos, a sua delegação a prestadores privados; e (vi) o oferecimento das utilidades aos cidadãos de forma gratuita ou remunerada, sempre destinadas a promover o bem estar da coletividade.

Destaque-se a exclusão, por Aragão (2007, p. 170), dos serviços uti universi do conceito operacional proposto para os serviços públicos. Para o autor, os serviços uti universi (prestados à coletividade de forma indistinta, inespecífica e indivisível iluminação pública, segurança pública, etc.) e os serviços uti singuli (prestados a usuários individualizáveis e em quantidade mensurável), ao contrário do que afirma a tradição doutrinária brasileira, não possuem traços em comum que justifiquem sua colocação em um mesmo conceito. $\mathrm{O}$ fato de em ambos os casos existirem atividades materiais prestadas pelo Estado não ilidiria diferenças de regime como a forma de financiamento e remuneração dos serviços, a possibilidade de delegação, dentre outras. Nos serviços uti universi, a dificuldade em identificar um usuário denotaria que, do ponto de vista técnico, não haveria, a rigor, um serviço público, mas uma função pública.

Há que se consignar a existência de entendimentos distintos a esse respeito. Pedro Gonçalves (1999, p. 36) centra a noção de serviço público no seu caráter prestacional: "O serviço público não é qualquer actividade da Administração, sendo antes a qualificação de um certo tipo de tarefas administrativas cujo elemento essencial se encontra no conceito de prestação".

$\mathrm{O}$ autor resume as principais características dos serviços públicos, incluindo nesse rol aqueles de caráter uti universi, já que, no seu entendimento, o caráter prestacional, noção fundamental dos serviços públicos, não se concretiza necessariamente na forma de uma relação jurídica direta com o usuário (uti singuli), sendo antes uma 'técnica operativa', um modo de atuar que encontra também nos serviços indivisíveis. Mesmo indivisível, o fundamental é que serviço público proporcione benefícios diretos a terceiros: 
Ao factor de distinção centrado no conceito de prestação, podem acrescentar-se outros elementos que contribuem para caracterizar o serviço público: ele traduz uma actuação administrativa de carácter positivo (em que a Administração não se limita a regular, planear, a incentivar ou a conservar), de natureza técnica (distribuição de água, ensino, prestação de cuidados da saúde) e não jurídica (actos jurídicos), que satisfaz, directa ou indirectamente, necessidades colectivas dos indivíduos - a prestação pode ser uti singuli, a cada cidadão, ou não: é serviço público o sistema estadual de abastecimento de água aos municípios, que eles depois distribuem aos cidadãos, assim como o é a exploração de um serviço de radiodifusão. Ou seja, o destaque conferido ao factor prestação não pretende limitar o conceito de serviço público às actividades que se desenvolvem segundo o esquema das relações de prestação entre o gestor do serviço e os utentes. Nestes termos, há o serviço público quando a uma entidade pública é confiada uma actividade de prestação em benefício público ( $v . g$. abastecimento de água pelo Estado aos municípios), assim como pode haver serviços públicos 'sem utentes determinados' (com quem o gestor possa constituir uma relação jurídica de prestação), como são os casos dos serviços públicos de telecomunicações de difusão ou o serviço de iluminação pública. A prestação não é aqui entendida como a base de uma relação jurídica, mas antes como uma 'técnica operativa', um 'modo de actuar' ou 'um processo de acção administrativa'.

Embora não tenha de consistir numa prestação ao público, parece-nos no entanto essencial que o serviço público tenha por objecto prestações a efectuar por uma entidade em benefício directo e imediato de terceiros.

Por outro lado, o serviço público consiste numa prestação (de bens ou de serviços). Assim, não é serviço público a actividade (pública) que consiste em gerir, manter e conservar uma coisa pública e facultar o seu uso a terceiros - o gestor (da rede de telecomunicações ou da rede ferroviária) exerce uma actividade que tem como objecto a coisa (conservação, manutenção); a utilidade que ele proporciona a terceiros (faculdade de utilização contra o pagamento de taxas ou preços) não é por isso autônoma da própria coisa que gere. O serviço público pode ter objecto actividades econômicas (serviços públicos econômicos) - é esta categoria de serviços que mais nos interessa, uma vez que a concessão de serviços públicos tem aí o seu espaço preferencial), sociais (serviços públicos de saúde e de segurança social) ou culturais ( $v . g$. serviço público de ensino). (GONÇALVES, 1999, p. 37-39)

O autor traz, portanto, para o conceito de serviços públicos, as prestações uti universi, posição que será relevante para compreensão da natureza jurídica de algumas das atividades que integram o saneamento.

Com base nos subsídios teóricos obtidos neste item, será delineada no tópico subsequente um posicionamento conceitual do saneamento como espécie de serviço público. 


\subsubsection{O saneamento como serviço público}

Foram mencionados neste tópico dispositivos constitucionais e legais a respeito do saneamento. A mera referência a tais normas traz à tona questões relevantes sobre as competências a respeito da produção normativa e prestação material dos serviços de saneamento e outros temas pertinentes ao seu regime jurídico. Tais discussões serão empreendidas nos capítulos seguintes, em razão da organização lógica adotada como linha referencial deste trabalho.

Por ora, será prudente apenas destacar os dispositivos ou determinações que auxiliem a compreensão da natureza do saneamento.

A Constituição da República, além das normas gerais sobre os serviços públicos, traz disposições específicas sobre o saneamento básico que devem ser, necessariamente, relacionadas.

O inciso XX do art. 21 da Constituição da República atribui à União a tarefa de instituir diretrizes para o desenvolvimento urbano, o qual inclui, dentre outros tópicos, o saneamento básico.

No rol das competências político-administrativas, o Texto Maior preceitua, ainda, que é atribuição comum a todos os entes federados a promoção de "programas de construção de moradias e a melhoria das condições habitacionais e de saneamento básico" (art. 23, IX). Aqui, a tônica é dada à cooperação como mecanismo para a realização da atividade administrativa, a ser implementada na forma preconizada em lei complementar, que visará ao equilíbrio do desenvolvimento e do bem-estar em âmbito nacional (art. 23, parágrafo único).

O inciso V do art. 30 da Constituição determina, por sua vez, que compete aos Municípios "organizar e prestar, diretamente ou sob regime de concessão ou permissão, os serviços públicos de interesse local, incluído o de transporte coletivo, que tem caráter essencial".

Não há no Texto Constitucional, a rigor, uma regra que nomine expressamente os serviços de saneamento como públicos, ainda que essa ilação possa ser realizada em razão do disposto no inciso IX do art. 23 e também se considerados tais serviços como 
atividades de interesse local (interpretação plenamente plausível em muitos aspectos), o que acarretaria a incidência imediata do inciso V do art. 30, acima indicado.

Verifica-se, de outro lado, sem sombra de dúvida, que a Constituição reconhece o saneamento como uma atividade de interesse coletivo, visto que, por diversas vezes, o aloca no rol de preocupações básicas dos entes federados.

Sobretudo em razão do disposto no art. 21, XX, da Constituição, faz-se necessário um olhar aproximado do disposto na legislação ordinária sobre esses serviços.

Essa análise preliminar não resultará na elucidação de todo o regime do setor, apenas dos aspectos que envolvem a qualificação do saneamento como serviço público. Posteriormente, aprofundamentos no regime jurídico serão naturalmente realizados para compreensão da gestão compartilhada dos serviços.

A Lei n. 11.445/2007 (Lei Nacional de Saneamento - LNS) expressamente denomina o saneamento como serviços públicos: "Art. $2^{\underline{0}}$ Os serviços públicos de saneamento básico serão prestados com base nos seguintes princípios fundamentais: [...]".

Já a titularidade dos serviços de saneamento é inquestionavelmente pública, como decorre da leitura de dispositivos da lei, como os arts. $8^{\circ}$ e $9^{\circ}$, bem como do fato de que a prestação dos serviços por terceiro que não integre a administração do titular depende da celebração de contrato (art. 10). ${ }^{24}$

Além disso, a Lei n. 11.445/2007 é permeada por normas e regras de caráter público e especial que visam garantir a regulação, a sustentabilidade e o equilíbrio econômico da prestação, bem como a participação da sociedade no controle dos serviços, dentre outros aspectos que conformam um subsistema jurídico próprio.

Percebe-se que, a partir desse ponto, vão se consolidando os elementos que permitirão tratar o saneamento básico como categoria.

Com efeito, constituem atividades de titularidade exclusiva do Poder Público, passíveis de delegação aos particulares, destinadas ao atendimento de uma necessidade coletiva, desempenhadas segundo um regime jurídico predominantemente público que assegura sua continuidade e regularidade em benefício dos cidadãos.

\footnotetext{
${ }^{24}$ Nos termos da Lei Nacional de Saneamento: “Art. $8^{\circ}$ Os titulares dos serviços públicos de saneamento básico poderão delegar a organização, a regulação, a fiscalização e a prestação desses serviços, nos termos do art. 241 da Constituição Federal e da Lei $n^{\circ} 11.107$, de 6 de abril de 2005. Art. $9^{\circ} \mathrm{O}$ titular dos serviços formulará a respectiva política pública de saneamento básico, devendo, para tanto: [...]. Art. 10. A prestação de serviços públicos de saneamento básico por entidade que não integre a administração do titular depende da celebração de contrato, sendo vedada a sua disciplina mediante convênios, termos de parceria ou outros instrumentos de natureza precária."
} 
Da análise das características de seu regime jurídico decorre a conclusão, um tanto óbvia tendo em vista o histórico do setor e as determinações legais descritas, de que os serviços de saneamento constituem serviços públicos.

Com base nas atividades integrantes do saneamento será possível direcionar um olhar mais preciso a respeito de sua caracterização como serviço público. São elas, nos termos do inciso I do art. $3^{\circ}$ da Lei n. 11.445/2007, o conjunto de serviços, infraestruturas e instalações operacionais de:

a) abastecimento de água potável: constituído pelas atividades, infraestruturas e instalações necessárias ao abastecimento público de água potável, desde a captação até as ligações prediais e respectivos instrumentos de medição;

b) esgotamento sanitário: constituído pelas atividades, infraestruturas e instalações operacionais de coleta, transporte, tratamento e disposição final adequados dos esgotos sanitários, desde as ligações prediais até o seu lançamento final no meio ambiente;

c) limpeza urbana e manejo de resíduos sólidos: conjunto de atividades, infraestruturas e instalações operacionais de coleta, transporte, transbordo, tratamento e destino final do lixo doméstico e do lixo originário da varrição e limpeza de logradouros e vias públicas;

d) drenagem e manejo das águas pluviais urbanas: conjunto de atividades, infraestruturas e instalações operacionais de drenagem urbana de águas pluviais, de transporte, detenção ou retenção para o amortecimento de vazões de cheias, tratamento e disposição final das águas pluviais drenadas nas áreas urbanas.

Em linhas gerais, poder-se-ia dizer que as atividades integrantes do saneamento constituem serviços públicos econômicos no sentido defendido por alguns dos autores tratados no tópico anterior deste trabalho: constituem espécie de atividades econômicas que, a despeito de atenderem a um interesse social de grande envergadura, podem ser inseridas em um regime de exploração econômica sem que sua essência seja desnaturada.

Certamente, tal caracterização não seria unânime. Dúvidas surgiriam a respeito de algumas das atividades do saneamento que, em uma avaliação preliminar, em razão de sua aparente indivisibilidade, impediram uma relação direta com o usuário, a obstaculizar sua classificação como serviço uti singuli sendo, portanto, excluídas, na visão de alguns autores, não apenas da noção de serviços públicos econômicos, como do conceito de 
serviço público. São exemplos o manejo de águas pluviais e a varrição, capina e poda de vias e logradouros, atividades as quais, em uma análise muito perfunctória, destinam à coletividade urbana de forma indistinta.

Recorde-se a posição adotada por Aragão, descrita no item precedente deste capítulo, que não inclui os serviços uti universi no rol estrito de serviços públicos que o autor idealiza como o mais operacional.

Justen Filho (2005a, p. 206) pondera que, no conceito de serviço de saneamento básico, inúmeras das atividades nem configuram um serviço público em sentido técnico-jurídico. Diz o autor: "O manejo de águas pluviais claramente não pode ser reconduzido ao instituto do serviço público".

Há argumentos que podem ser facilmente contrapostos a essa visão. Em primeiro lugar, a união, promovida pelo legislador ordinário, no mesmo conceito de saneamento, de serviços díspares em sua estrutura econômica, como varrição e limpeza de logradouros públicos, drenagem urbana, abastecimento de água e coleta de esgoto, se revela coerente pela pertinência temática entre as citadas atividades e pelo fato de que todas elas apresentam impactos recíprocos (conforme demonstrado em maiores detalhes no capítulo 2 deste trabalho).

Os serviços em questão, direta ou indiretamente, propiciam aos cidadãos condições sanitárias de vida adequadas, circunstância que justifica seu tratamento sistêmico e integrado. Seriam incompletas as ações de saneamento que prescindissem de qualquer das atividades descritas no inciso I do art. $3^{\circ}$ da Lei n. 11.445/2007.

Bem afirma Marques Neto (2005a, p. 29) que é

praticamente impossível separar, no saneamento ambiental, as atividades
divisíveis das indivisíveis. Por primeiro, porque a não execução de umas pode
anular o benefício da prestação de outras (inimaginável, por exemplo, uma
cidade com coleta domiciliar irrepreensível, mas com varrição e coletas sofríveis
na área pública).

Ao menos para a Lei Nacional de Saneamento, a suposta indivisibilidade das atividades acima descritas encontra-se superada, já que, em diversos dispositivos, prevê a cobrança de taxas e tarifas para os serviços de limpeza urbana e manejo de águas pluviais (nesse sentido, os arts. 29, 35 e 36 da lei em comento, que disciplinam regime de cobrança de taxas e tarifas para os serviços de limpeza urbana e drenagem). Ou seja, prevê formas de 
remuneração dos serviços que, ao pressupor sua divisibilidade, indicariam, indiretamente, o caráter uti singuli dessas atividades. ${ }^{25}$

Admite-se que a cobrança de taxas e tarifas pela prestação de serviços em que a divisibilidade é controversa ou duvidosa tem sido objeto de calorosas discussões nos tribunais. $^{26}$

Contudo, o fato de que, por suposição, a Lei Nacional de Saneamento, no que prevê a cobrança de taxas e tarifas para atividades supostamente indivisíveis, pode, no futuro, ser submetida a um juízo de inconstitucionalidade (fato ocorrido com a taxa de iluminação pública, mais tarde transformada no Texto Constitucional em contribuição para iluminação pública ${ }^{27}$ ), não afasta a inserção das atividades do saneamento na noção de serviços públicos, nem descaracteriza o seu viés econômico.

Mesmo que se conclua, do ponto de vista técnico e jurídico, pelo caráter uti universi de algumas das atividades, remanesce sem sentido a associação da noção de serviços públicos apenas às atividades passíveis de vinculação direta com os usuários.

Conforme demonstrado no item precedente deste trabalho, o caráter geral dos serviços uti universi não deve ser empecilho para sua inserção na categoria dos serviços públicos, tampouco ilide a faceta prestacional de que se reveste a atividade.

O manejo de águas pluviais e a varrição, a poda e a capina de ruas proporcionam utilidades valiosas, em benefício concreto dos cidadãos, sendo essa a nota fundamental a estabelecer uma relação direta entre os serviços e os usuários, e não a forma

25 Destaque-se que o Município de Santo André instituiu cobrança de taxa para custeio dos serviços de drenagem urbana, contornando a suposta indivisibilidade dos serviços. Nesse sentido, ver a Lei Municipal n. 7.606, de 23 de dezembro de 1997, segundo a qual a taxa de drenagem é devida em razão da utilização efetiva ou da possibilidade de utilização, pelo usuário, dos serviços públicos de drenagem de águas pluviais, decorrentes da operação e manutenção dos sistemas de micro e macrodrenagem existentes no Município (art. $2^{\circ}$ ). O Contribuinte da taxa é o proprietário, o titular do domínio útil ou o possuidor, a qualquer título, de bem imóvel abrangido pelo serviço público de drenagem de águas pluviais (art. $3^{\circ}$ ). $\mathrm{O}$ custo decorrente da prestação dos serviços de operação e manutenção dos sistemas de micro e macrodrenagem será dividido proporcionalmente entre cada usuário, segundo a contribuição volumétrica das águas advindas de seu respectivo imóvel, lançadas ao sistema de drenagem urbana. O cálculo da contribuição volumétrica de águas ao sistema de drenagem terá por base o índice pluviométrico médio mensal do Município que, associado à área coberta de cada imóvel, definirá o volume efetivamente lançado ao sistema (art. $4^{\circ}$ ).

${ }^{26}$ Atente-se para a necessidade de distinguir as situações em que a divisibilidade não é possível daquela em que é excessivamente custosa por exigir operações técnicas ou tecnologias caras e dispendiosas.

${ }^{27}$ Conforme dispõe a Constituição da República a respeito dos serviços de iluminação pública: "Art. 149-A. Os Municípios e o Distrito Federal poderão instituir contribuição, na forma das respectivas leis, para o custeio do serviço de iluminação pública, observado o disposto no art. 150, I e III. (Incluído pela Emenda Constitucional n. 39, de 2002). Parágrafo único. É facultada a cobrança da contribuição a que se refere o caput, na fatura de consumo de energia elétrica. (Incluído pela Emenda Constitucional n. 39, de 2002)". 
de remuneração ou financiamento adotada para a sustentabilidade econômica da prestação. Nesse sentido, leciona Marques Neto (2005a, p. 34):

\begin{abstract}
Pode haver relação direta entre prestador e usuário final, sem que este remunere diretamente àquele. A relação direta atine à prestação e não à remuneração. Não fosse assim e restaria interditada qualquer possibilidade de poder público promover políticas de gratuidade tarifária ou de tarifas sociais, arcando com parte ou toda a tarifa cabente aos usuários beneficiados.
\end{abstract}

Em suma, ainda que seja razoável encarar os serviços uti singuli como os serviços econômicos por definição, é difícil negar que alguns serviços uti universi também possuem um conteúdo econômico (iluminação pública, varrição e limpeza de logradouros públicos e drenagem são exemplos interessantes). Esses serviços são passives de mensuração econômica e de delegação a terceiros, remunerados por meio de recursos do erário (impostos) e outros mecanismos tributários ou tarifários.

De fato, a suposta incompatibilidade de natureza entre os serviços uti singuli e uti universi vem sendo mitigada por recentes inovações do ordenamento jurídico brasileiro. Tipos contratuais como a concessão administrativa (prevista pela Lei Federal n. 11.079/04), a qual pressupõe o pagamento da remuneração do concessionário exclusivamente pelo Poder Público, possibilitam que atividades indivisíveis possam ser delegadas a particulares em um regime de concessão de serviços públicos, a aproximar, portanto, o regime de prestação e organização gerencial dos serviços.

Por óbvio que nem todos os serviços uti universi estão sujeitos à admissibilidade plena de sua delegação ou à aproximação de seu regime com o dos serviços uti singuli. Não há que se comparar o conteúdo econômico e a delegabilidade da iluminação pública ou da varrição com os atributos da segurança pública ou das atividades judiciárias de solução de conflitos, sabidamente indelegáveis no que concerne ao seu conteúdo fundamental. ${ }^{28}$

Isso prova que mesmo entre os serviços uti universi existem diferenças internas que dificultam sua categorização homogênea, a corroborar a afirmação de que a inserção dos serviços em conceitos muitas vezes oriundos do direito estrangeiro perde força diante

\footnotetext{
${ }^{28}$ Note-se que cada vez mais a Administração tem ousado nessa seara, sendo exemplo, em Minas Gerais, a contratação de concessão administrativa para construção e administração de penitenciárias do Estado. Nesse caso, é mantida a participação dos órgãos de segurança do Estado no desempenho do poder de polícia necessário ao funcionamento das unidades penitenciárias.
} 
da realidade fornecida pela legislação local e mesmo pela evolução técnica da prestação dos serviços, que pode apresentar meios de cobrança (divisibilidade) ou relacionamento direto com os usuários dantes inexistentes.

As colocações aqui realizadas comprovam que o serviço público e todas as demais noções, conceitos e classificações a ele atreladas são antes facilitadores de uma aproximação inicial do que indicadores absolutos da natureza das atividades examinadas.

A atividade classificatória do direito, salutar e necessária, não deve ser mais relevante que a própria realidade que visa tutelar. As noções conexas ao serviço público (suas múltiplas classificações e subdivisões), como já afirmado, permitem uma primeira abordagem que, após exame gradual e aprofundado, paulatinamente indicará as características individuais de cada serviço e que condicionam a sua realização concreta.

Cada situação deve ser avaliada segundo seus determinantes concretos, sendo improvável encontrar categoria ou classificação que abarque de forma satisfatória todas as hipóteses reais, mesmo quando considerado um universo mais restrito como o do saneamento.

As formas de relacionamento do serviço com o usuário, bem como os mecanismos para seu custeio e financiamento, serão compatíveis com suas características estruturais, a propiciar ou a manutenção dos serviços por meio de receitas de impostos (desembolsos diretos do Poder Concedente) ou por meio da cobrança de taxa, tarifas e contribuições, sendo que os tipos remuneratórios utilizados não podem representar critério definitivo para a classificação ou não de uma atividade como serviço público e mesmo como serviço público com feições econômicas.

\subsection{O SANEAMENTO E SUA RELAÇÃO COM AS FRONTEIRAS DO INSTITUTO DOS SERVIÇOS PÚBLICOS: A TENSÃO ENTRE A COESÃO SOCIAL E A EFICIÊNCIA ECONÔMICA E A GESTÃO COMPARTILHADA NESSE CONTEXTO}

Como visto, os desafios da dogmática são grandes quando se trata do serviço público. Uma categoria que, a par das pressões transformadoras que constantemente a 
assolam, compartilha ainda os desafios vividos pelo Direito Administrativo desde seu surgimento.

Não é novidade que o Direito Administrativo é um ramo mais sensível às sucessivas transformações experimentadas pela sociedade. Sua colocação a meio caminho entre o exercício de poder estatal e a proteção da liberdade dos cidadãos faz com seja profundamente influenciado pelas distintas configurações do Estado e das relações deste com a sociedade civil. $^{29}$

Pela razão de que a hipersensibilidade em relação às mutações sociais é congênita ao Direito Administrativo, há décadas perduram debates a respeito de suas fronteiras e funções, acarretando, em situações limites, alegações sobre supostas crises de identidade e esfacelamento de suas características primordiais. ${ }^{30}$

As alegadas crises abrangem desde aspectos metodológicos e epistemológicos que concernem diretamente ao modo de produção científica e às possibilidades de conhecimento do direito público (o Direito Administrativo como objeto de estudo), até aspectos operacionais relacionados à aplicação prática do direito. A rigor, muitas dessas discussões dizem respeito a todo o Direito, e não apenas ao ramo administrativo.

As mutações do Direito Administrativo em resposta às pressões da realidade circundante constituem um esforço interno e natural de sobrevivência de qualquer sistema jurídico que almeje regular minimante a realidade social.

Os processos de reformulação, reposicionamento e reorganização dos postulados fundamentais desse ramo do Direito não são, assim, obstáculos à sua permanência e força, mas, antes, mecanismos de sustentação inatos a um setor jurídico cuja característica fundamental é a de ser umbilicalmente conectado à noção de Estado.

Nesse sentido, a relação do Direito Administrativo com seu passado não pode ser a de solidificação absoluta de postulados, mas de superação e, de certo modo, da

\footnotetext{
${ }^{29}$ Nesse sentido, Marques Neto (2002c, p. 61), para quem o "Direito Administrativo é, a um só tempo, um ramo do Direito Público e um ramo de operacionalização do poder político, balizando inclusive a atuação deste poder em outras áreas do jusplubicismo" (2002c, p. 60). Conforme reitera o autor, "dessa íntima vinculação do Direito Administrativo com a específica configuração do poder político própria à Modernidade advém todo um arcabouço de normas, princípios, métodos e pressupostos que constituem esse ramo do juspublicismo".

${ }^{30}$ Para uma compreensão abrangente das transformações do Direito Administrativo recomenda-se Dias (2003).
} 
realização de ideias e caminhos seminais, inaugurados nesse mesmo passado, que não será apenas superado, mas, antes, reafirmado naquilo que já continha de novo. ${ }^{31}$

Em linhas gerais, tais transformações podem ser sintetizadas nos seguintes termos: uma aproximação cada vez maior entre o público e o privado no Direito Administrativo; a inter-relação cada vez mais frequente de institutos jurídicos de direito público e aqueles oriundos de outros ramos do Direito (fluidez de fronteiras) e o maior reconhecimento da influência de outras esferas do conhecimento (economia, política, etc.) na normatividade promovida pelo Direito Administrativo.

De igual maneira, o serviço público é um microcosmo em que todas essas ponderações se aglutinam.

Bem por isso, é comum a afirmação de que a noção de serviço público encontrar-se-ia em crise, representada por modificações em seu regime jurídico que, em seu conjunto, acarretam a perda da identidade original do instituto.

Os dilemas dos serviços públicos vêm, há muito, sendo objeto de estudos e considerações teóricas. Curiosamente, apesar da existência de variados escritos sobre a questão, sua importância constantemente se renova. A explicação é simples: a delimitação das fronteiras do serviço público (ou pelo menos a tentativa de delimitação) indica o grau de liberdade que os particulares terão no desempenho de serviços que, em sua maioria, consistem em atividades econômicas muitas vezes altamente lucrativas.

Ademais, a tentativa de decifrar o serviço público, acompanhar seu desenvolvimento gradual, equivale a tratar da atuação do Estado na sociedade em suas mais variadas dimensões. Determinar o papel e a extensão dos serviços públicos como

\footnotetext{
${ }^{31}$ Considerando que o Direito Administrativo vive um constante debate a respeito da evolução de seus conceitos fundamentais e sem o pendor de esgotar as bases filosóficas integrantes de uma teoria da evolução social (e das ideias, instituições e bens socioculturais), reconhece-se a existência de diferentes concepções a respeito da receptividade e apropriação pelo presente de experiências do passado. Habermas (2002, p, 21-22) explica que Walter Benjamin, detentor de uma consciência histórico-receptiva peculiar, "desconfia igualmente tanto do tesouro de bens culturais legados, que devem passar a ser posse do presente [...]. Em virtude disso Benjamim propõe uma drástica inversão entre o horizonte de expectativa e o campo de experiência. Atribui a todas as épocas passadas um horizonte de expectativas insatisfeitas, e ao presente orientado para o futuro designa a tarefa de reviver na reminiscência de um passado que cada vez lhe seja correspondente, de tal modo que possamos satisfazer suas expectativas com nossa débil força messiânica". As gerações passadas manteriam, portanto, suas expectativas direcionadas para as gerações presentes, encarregadas estas da dura responsabilidade de satisfazer expectativas não realizadas. Com essa radicalização da consciência histórico-receptiva das ideias traça-se um instigante paralelo com a situação do Direito Administrativo atual e talvez do Direito como sistema social, aos quais se impele, quase que com dimensões messiânicas, o dever de recepção e realização, por meio de seus institutos e nele congregadas, das expectativas de gerações passadas.
} 
instrumento de atuação estatal significa delinear uma concepção de Estado e, em parte, do Direito Administrativo que a subjaz.

Não sem razão, as alterações no perfil do funcionamento do Estado e da Administração Pública no Brasil promovida pelas reformas estruturais recentemente empreendidas impactam diretamente no entendimento dos serviços públicos.

Como informa Campilongo (2005, p. 46),

\begin{abstract}
tem-se a impressão, diante da magnitude dos chamados 'ajustes estruturais' que desembocaram em privatizações, novas formas de pactuação entre a Administração Pública e os particulares, criação de 'Agências Reguladoras', incentivos à competição e aos mecanismos de mercado, expansão de formas de regulação privada e consensual e, por fim, na chamada globalização -, de que as categorias convencionais da Teoria do Direito são incapazes de descrever a realidade das novas operações do sistema.
\end{abstract}

$\mathrm{O}$ autor bem identifica dois planos distintos nos quais se processa o embate para a reorganização sistêmica da noção de serviço público em meio às referidas mudanças do ambiente estatal. No plano interno ao sistema jurídico, a divisão do direito em grandes ramos estanques perde sua funcionalidade, uma vez que dificulta a visão integrada do regime aplicável aos serviços. (CAMPILONGO, 2005, p. 46-48)

No plano externo, há dificuldades para diferenciar o sistema jurídico dos sistemas político e econômico ou mesmo para racionalizar a atração que esses sistemas exercem sobre os serviços públicos.

Para Campilongo (2005, p. 50), o maior risco reside no desrespeito aos limites funcionais e operativos do Direito, cobrado, nesse novo contexto, em relação a prestações que não conseguirá suprir isoladamente, pois próprias da economia (superação da escassez de recursos e maximização de bem-estar) ou da política (proporcionar a tomada de decisões coletivas e adotar programas finalísticos).

Em que ponto se situa o saneamento no que diz respeito à perspectiva acima traçada?

A primeira ponderação que resultará em resposta à pergunta colocada reside no reconhecimento de disparidades significativas entre os tipos de serviços públicos, cada 
qual submetido a formas e intensidades de gestão e regulação próprias, sustentadas cada qual por conjunturas econômicas e históricas particulares. ${ }^{32}$

Em outras palavras, manifestam-se de forma peculiar em cada setor os fatores impulsionadores das modificações nos regimes dos serviços, quais sejam: (i) as transformações das atividades materiais que constituem os serviços, notadamente sua evolução tecnológica; (ii) as alterações institucionais que implicam inovações nas formas de gestão, delegação e regulação dos serviços e a (iii) evolução normativa a respeito dos serviços, que atinge o conteúdo de sua prestação, indicando novos parâmetros materiais de prestação da atividade regulada.

No primeiro caso, a evolução técnica das atividades materiais de prestação pode redundar em modificações substanciais da gestão dos serviços, com reflexos profundos no seu regramento. ${ }^{33}$

Setores antes caracterizados como monopólio natural podem, em razão do desenvolvimento tecnológico, dar lugar a atividades em que, por exemplo, a competição se torna viável e altamente salutar para os usuários uma vez que pode resultar em tarifas menores. A relação entre concorrência e incremento tecnológico é, com efeito, caracterizada pela influência recíproca.

De seu lado, o aumento progressivo da pressão concorrencial é capaz de oferecer maior dinamização tecnológica, pois os prestadores objetivarão serviços mais eficientes e atraentes a preços módicos. Deveras, inovações tecnológicas trazem barateamento de custos e favorecem a universalização dos serviços.

No saneamento, tanto o alcance de um nível tecnológico ótimo como a criação de um ambiente de concorrência dependem de um processo evolutivo ainda não atingido

\footnotetext{
${ }^{32}$ Segundo Grotti (2003, p. 89), “a Constituição não trata, porém, todos os serviços de maneira uniforme. Os objetivos visados são diferentes; a competência para a prestação, bem como as formas de organização e de gestão as distintas; a natureza jurídica da remuneração paga pelos usuários de serviços públicos prestados uti singuli varia; a aplicação dos princípios de direito público especialmente reportados aos serviços com diferente intensidade; há submissão, em graus variáveis, a um regime de direito público e, em algumas situações, ao direito privado. Não há, enfim, um tratamento jurídico uniforme em relação a todos eles. Existem regras constitucionais específicas acerca de questões peculiares".

${ }^{33}$ A respeito da evolução tecnológica nas telecomunicações e seus efeitos na regulação, diz Marques Neto (2002b, p. 361): "Em todos os setores que estão passando por transformações jurídicas, no Brasil e no mundo, existe uma força de propulsão denominada tecnologia. Assim é com a energia elétrica, o petróleo, o saneamento e, sobretudo, o setor de telecomunicações. Para ilustrarmos esta situação basta verificar que há cinco anos a telefonia celular era o que havia de mais moderno para acesso ao mundo da alta tecnologia. Contudo, hoje esta tecnologia está completamente incorporada à nossa vida cotidiana, havendo a chamada 'popularização do celular'. Este fato traz uma série de consequiências do ponto de vista da regulação do setor".
} 
em sua plenitude. O reduzido grau de inovação tecnológica no setor diminui sua submissão às pressões transformadoras típicas dos serviços públicos.

No que toca ao regime institucional e jurídico do saneamento, o advento da Lei n. 11.445/2007 representou um avanço significativo, sedimentando algumas controvérsias existentes no setor e favorecendo a segurança jurídica para concessionários e Poder Público.

A densificação das regras sobre a titularidade dos serviços, o advento da gestão compartilhada, a necessidade de planejamento da gestão pelo Poder Público titular, a obrigatoriedade de formulação de contratos para prestação dos serviços e as regras relativas à regulação social e econômica do saneamento contribuem enormemente para a segurança jurídica do setor e, em algumas hipóteses, constituem novidades que compõem um quadro normativo efetivamente mais avançado.

A despeito da significativa evolução normativa verificada, alguns dos polos fundamentais de funcionamento do saneamento como serviço público remanescem estáveis, ainda que de forma aclarada: o Poder Público como titular dos serviços; a possibilidade de prestação direta ou delegada e a incidência sobre os serviços de um regime jurídico predominantemente público.

Tais circunstâncias não tornam o saneamento imune às vagas de mudança que periodicamente atingem o Direito Administrativo. Sempre haverá espaço para inovações. Há que se reconhecer apenas que o saneamento vive situação distinta de outros setores, como os serviços de telecomunicações, em que a pressão tecnológica e um regime jurídico peculiar conferem notas especificas ao caso e exigem da doutrina um esforço sistematizador (e em algumas hipóteses emancipador em relação a noções dantes prevalentes) consideravelmente maior.

Embora o confronto do saneamento com as fronteiras do serviço público se dê em curso menos caudaloso, o setor compartilha alguns dilemas que o instituto vive desde seus primórdios, tendo sido acentuada hodiernamente em vista das linhas de eficiência e resultados que permeiam a atuação pública, em especial no que toca ao controle dos gastos públicos. 
É tradicional na doutrina a diferenciação entre atividade econômica em sentido estrito e serviço público lavrada na interpretação conjugada dos arts. 173 e 175 da Constituição da República. ${ }^{34}$

A aceitação dessa distinção e o reconhecimento de que o serviço público se encontra pautado por princípios de envergadura própria como a universalidade, a continuidade, a atualidade, dentre outros, não eliminam o fato de que a instituto comunga desafios e características basilares com as atividades econômicas em sentido estrito.

Calcados justamente no caráter prestacional do serviço público, a abranger uma atividade material ou utilidade concreta, muitos autores não se têm furtado a afirmar a identificação do serviço público como espécie de atividade econômica, uma vez que seu objetivo primordial consiste na satisfação de necessidades materiais dos usuários lastreadas em recursos escassos. Uma atividade passível de valoração econômica. ${ }^{35}$

É justamente a faceta econômica dos serviços públicos que provoca uma sensação natural de contradição e tensão derivada da coexistência entre necessidades sociais a suprir e as expectativas associadas ao fato de que a utilidade oferecida é, muitas vezes, uma atividade desenvolvida em um contexto de escassez fiscal, a impor sua sustentabilidade por meios próprios.

Em certos aspectos, o conceito de serviço público corresponderia a uma noção de embate. Palco do confronto entre a eficiência econômica ${ }^{36}$ e valores que, assimilados

${ }^{34}$ A distinção em referência é bem evidenciada por Bandeira de Mello (1997, p. 21-22): "Igualmente, a expressão 'serviços' (ensejando a suposição de que seriam 'serviços públicos') é utilizada em sentido natural - e não técnico-jurídico - para nomear atividades industriais ou comerciais que o Estado desempenha basicamente sob regime de direito privado - antítese do que ocorre com o serviço público por se constituírem em exploração de atividade econômica, isto é, atividades ubicadas em setor reservado aos particulares, à iniciativa privada - igualmente antítese do que ocorre com o serviço público. [...] A separação entre os dois campos - serviço público, como setor pertencente ao Estado e domínio econômico, como campo reservado aos particulares - é induvidosa e tem sido objeto de atenção doutrinária, notadamente para fins de separar empresas estatais prestadoras de serviço público das exploradoras da atividade econômica, ante a diversidade de seus regimes jurídicos".

${ }^{35}$ É famosa a relação entre serviços públicos e atividade econômica evidenciada por Grau (2008, p. 101): “A prestação de serviço público está voltada à satisfação de necessidades, o que envolve a utilização de bens e serviços, recursos escassos. Daí podermos afirmar que o serviço público é um tipo de atividade econômica. Serviço público - dir-se-á mais - é o tipo de atividade econômica cujo desenvolvimento compete preferencialmente ao setor público. Não exclusivamente, note-se, visto que o setor privado presta o serviço público em regime de concessão ou permissão. Desde aí podemos afirmar que o serviço público está para o setor público assim como a atividade econômica está para o setor privado”.

${ }^{36}$ Embora sem pretensões científicas, são extremamente interessantes e perspicazes, e até um tanto irônicas, as colocações do antropólogo Sahlins (2004 sobre a economia como ciência, traçando um curioso paralelo com a tradição judaico-cristã e com a própria natureza humana. Sua descrição ilustra a inerente relação da economia com a superação da escassez e maximização das utilidades e, ironias à parte, reafirma o importante papel da ciência econômica moderna: "O castigo foi o crime. Ao desobedecer a Deus para satisfazer seus próprios desejos, ao colocar este amor demasiado a si mesmo acima do amor suficiente a 


\section{pelo Direito, almejariam à construção de uma sociedade pretensamente capaz de empreender uma maior e melhor distribuição de riquezas. ${ }^{37}$}

Ele, o homem condenou-se a tornar escravo de seus próprios anelos carnais insaciáveis: uma criatura limitada e ignorante, abandonada em um mundo meramente material e intratável, para ali labutar, sofrer e por fim morrer. Feitos de 'cardos e espinhos', resistente a nossos esforços, o mundo, disse Santo Agostinho, 'não cumpre o que promete: é um mentiroso e trapaceia'. A trapaça consiste na impossibilidade de aplicar nossos desejos libidinosos de bens terrenos, de dominação e de prazer carnal. O homem, portanto, está fadado 'a perseguir uma coisa após a outra e nada permanece para sempre com ele [...]. Suas necessidades multiplicam-se a tal ponto que ele não consegue encontrar a única coisa de que precisa, uma natureza simples e imutável'. Mas Deus foi clemente. Deu-nos a Economia. Advinda a época de Adão Smith, a miséria humana havia se transformado na ciência positiva de como nos havermos com nossas eternas insuficiências: como extrair a máxima satisfação possível utilizando meios sempre aquém de nossas necessidades. Trata-se da mesma antropologia judaico-cristã, só que aburguesada, isto é, dotada de expectativas algo mais animadoras a respeito das oportunidades de investimento propiciadas pelo sofrimento humano. Em um famoso ensaio que delineava o campo dessa ciência, Lionel Robbins reconheceu explicitamente que a gênese da Economia era a economia do Gênesis: 'Fomos expulsos do Paraíso', escreveu ele, 'não temos nem a vida eterna nem os meios ilimitados de gratificação' - em seu lugar apenas uma vida de escassez, onde escolher uma coisa boa é privar-se de outra. A verdadeira razão pela qual a Economia é a 'ciência desoladora' [dismal science] é que ela é a ciência da condição humana depois da Queda. E o Homem Econômico que a habita a primeira página de (quaisquer) Princípios Gerais da Economia não é outro senão Adão". (SAHLINS, 2004, p. 25-26)

${ }^{37} \mathrm{O}$ citado embate encontra-se presente também na experiência estrangeira a respeito dos serviços públicos. Embora alimentado por motivações distintas, sua essência ainda é a mesma e tem supedâneo nas imbricações do caráter simultaneamente econômico e social que muitos serviços públicos assumem. Nos tratados constitutivos da Comunidade Europeia, a noção de serviços públicos sofreu transformações sob o influxo das determinações atinentes à redução da participação do Estado na economia e à instituição do princípio da concorrência como pilar da união econômica entre os países.

Como bem observa Moreira (2003, p. 232), o regime caracterizador da Comunidade Econômica Europeia não eliminou a atuação econômica do setor público. A essa atuação econômica, entretanto, seria vedado, como regra geral, o comprometimento dos pilares fundamentais da ordem econômica comunitária: liberdade de circulação de bens e capitais; liberdade de circulação de pessoas, liberdade de prestação de serviços e liberdade de estabelecimento profissional e empresarial.

Nesse contexto, surge a noção de serviço de interesse econômico geral, prevista no art. 86 do Tratado da Comunidade Europeia (tal como delineado no Tratado de Roma e sucessivas alterações).

Os serviços de interesse econômico geral, cuja compreensão tem sido mote para intensos debates desde a década de 90, apresentam-se como tentativa de adaptação das atividades que inegavelmente destinam-se à satisfação de necessidades coletivas aos ditames da livre concorrência e do livre mercado em benefício da unificação econômica europeia.

De fato, a presença de atividades titularizadas pelo Estado em regime de monopólio ou com elevado controle de entrada simbolizaria entrave considerável aos objetivos da União Europeia.

Identificados com os serviços em rede (transporte, energia elétrica, telecomunicações), os serviços de interesse econômico geral podem, em tese, ser prestados tanto por empresas estatais, quanto por particulares, em regime de livre competição, sendo vedados favorecimentos públicos de qualquer ordem aos prestadores estatais ou particulares eventualmente vinculados ao Poder Público. Há, assim, nítida aproximação entre a noção de serviços de interesse econômico geral e as public utilities do direito anglosaxão.

Note-se, contudo, que as normas da Comunidade Europeia comportam expressamente a possibilidade de derrogação dos princípios retores da Comunidade Europeia (concorrência, livre mercado, etc.) na hipótese em que a realização da "missão" confiada aos serviços de interesse econômico geral o exija (necessidade de universalização dos serviços, de manutenção de sua sustentabilidade, entre outros motivos).

Desse modo, a experiência europeia é interessante para o caso brasileiro não tanto pelo fato de que exista no Brasil semelhante contexto comunitário, a infirmar as bases dos serviços públicos, mas pela perene busca por critérios que permitam indicar quando determinado serviço poderá figurar com exceção a regra da concorrência por se tratar de utilidade relevante para a coletividade e que justifica um tratamento especial do ordenamento jurídico. 
Espaço de tensão entre a busca pelo resultado econômico e condutas direcionadas ao bem-estar do usuário como a modicidade de custos e a universalização dos serviços.

Mesmo entre os supostos beneficiários das utilidades públicas a dicotomia é constatável. Em um país em que o setor de infraestruturas é ainda deficitário, convivem forçosamente os chamados consumidores "efetivos", que usufruem dos serviços, e aqueles que se encontram dele excluídos, taxados como consumidores "em potencial". No saneamento, por exemplo, foi demonstrado que durante os anos do Planasa predominou um discurso de autossustentabilidade dos serviços, cujos reflexos perpassam ainda o setor.

No campo político, o serviço público carrega o peso de discursos ora legítimos, ora demagógicos, que sintetizam desejos de grupos de interesse, conformando a base de políticas sociais e instrumento de legitimação de governos. (CAMPILONGO, 2005, p. 53)

Em meio a tantas tensões, não é difícil compreender por que a discussão em torno dos serviços públicos costuma ser caracterizada por posições apaixonadas e, em alguns casos, permeadas por uma forte carga ideológica.

O problema se intensifica quando a prestação se dá por meio da delegação a particulares. Salomão Filho (2001, p. 14) alerta para a inaptidão dos institutos de Direito Administrativo como mecanismos de disciplina dos mercados.

As concessões têm por pressuposto uma sinergia perfeita de interesses entre o setor público e o privado que não encontra guarida na realidade e que dependeria de uma inexistente capacidade de previsão pelo Estado dos fins da atividade econômica. Nas palavras de Salomão Filho (2002, p. 58),

as razões para o fracasso desse sistema são óbvias. Basta exemplificar com um problema de forma e de fundo. Quanto à forma, é saliente a incapacidade do

\footnotetext{
Não seria equivocado afirmar que o regime comunitário europeu vê os serviços de interesse econômico geral (à semelhança do que ocorre com o serviço público em sua faceta tradicional) como instrumento de coesão e desenvolvimento social, visão esta que assegurará, em determinadas hipóteses e como situação excepcional, sua prestação em regime total ou parcialmente contrário aos princípios comunitários de integração. A grande dificuldade para os europeus reside na identificação dessas situações e da exata medida (proporcionalidade) em que em que a derrogação dos princípios ocorrerá.

Assim, não herdamos necessariamente o mesmo problema pelo qual passam os europeus, pois não há uma pressão comunitária em prol da liberalização das atividades, e, pelo menos no saneamento, é inquestionável sua titularidade pelo Poder Público, mas também convivemos com o imperativo de obter critérios que permitam fazer valer a "a missão" fundamental dos serviços públicos e que envolve o direito à fruição universal de serviços essenciais em face das limitações econômicas indiscutivelmente presentes no tema.
} 
sistema contratual, nuclear para as concessões, de bem ordenar o cumprimento dos fins públicos. Mesmos dirigidos, tais contratos terão sempre como fim o arbitramento de interesses conflitantes entre as partes, ao menos se entendidos com sinalagmáticos ou de escambo. Tem por base princípios típicos desse tipo de relação, como o equilíbrio econômico contratual, que, recorrentemente, é usado em tema de concessões para justificar o descumprimento de fins públicos. Esse problema formal é, na verdade, manifestação de um problema de fundo mais grave. Trata-se do difícil ou desajustado encaixe do sistema de concessões em uma filosofia regulatória. Imaginado como remédio para as relações do Estado com o particular, da impossibilidade constitucional de tornar vinculante o planejamento para o setor privado, o sistema contratual fracassa, exatamente porque pouco apto a captar a pluralidade de interesses envolvidos pelo ambiente regulado.

Outra manifestação interessante do que foi afirmado se dá com as empresas públicas prestadoras de serviço público, muitas das quais formadas por capital público e privado (sociedades de economia mista). As empresas estaduais que prestam serviços de saneamento configuram o ambiente ideal para a contraposição dos interesses públicos (vinculados à expansão máxima dos serviços, inclusive para áreas com baixa capacidade de pagamento de tarifas) e privados (pertinentes aos acionistas particulares da empresa e tendentes à obtenção máxima de lucros).

Sem prejuízo do aprofundamento desses temas no curso do trabalho, é conveniente deixar claro que a compatibilização entre a lógica econômica, as pressões políticas e de grupos de interesse e as imposições pertinentes à coesão social e distribuição de riqueza assimiladas pelo ordenamento jurídico (com assento no regime constitucional brasileiro) conformam um grande painel que condiciona todo o processo de produção dos serviços.

Assim, no serviço público convergem expectativas oriundas dos sistemas jurídico, político e econômico, cada a qual operando por lógicas próprias e inconfundíveis. Bem afirma Campilongo (2005, p. 53) que "grande parte da agenda de problemas enfrentados pela noção de serviço público decorre da inexistência de teorias aptas a identificar e descrever as formas de articulação do direito com a política e a economia".

O maior risco em todo esse processo reside no desrespeito aos limites funcionais e operativos do direito em relação às exigências da economia (contorno da escassez de recursos e maximização de bem-estar) ou da política (promover a tomada de decisões coletivas e adoção de programas finalísticos).

Em suma, a questão colocada por Campilongo ao tratar dos serviços públicos reside na persecução da autonomia epistemológica do discurso jurídico nessa seara. 
Encontrar critérios jurídicos independentes para exame das eficiências econômicas e vicissitudes políticas que permeiam o instituto, tarefa que deve ser conciliada com uma peculiar estratégia metodológica marcada pela interdisciplinaridade entre Direito, Economia e Política e que consiga preservar a independência de cada sistema social.

Nas palavras do autor, a "interdisciplinaridade aqui sugerida como estratégia metodológica de redescrição do serviço público exige do intérprete dupla habilidade: balancear critérios jurídicos e econômicos, mas sem sacrificar uns em nome dos outros". (CAMPILONGO, 2005, p. 52-53)

Campilongo (2005, p. 50) explica os perigos da diluição do sistema jurídico (regime jurídico do serviço público) nos sistemas políticos e econômicos, quais sejam, a politização de caráter totalitário do direito ou sua mera mercantilização:

\begin{abstract}
Ao diluir o sistema jurídico no político, essa 'técnica' subtrai do direito especificidade funcional. Não há diferença entre 'politização do direito' e totalitarismo. Se os serviços públicos, em nome dos mais nobres fins, fossem objeto de mera manipulação política, livre dos constrangimentos e limites impostos pelo regime jurídico que lhes é peculiar, estariam irremediavelmente corrompidos e seriam imprestáveis enquanto categoria jurídica. De outra banda, dissolver o sistema jurídico no sistema econômico e promover a 'mercantilização dos direitos', especialmente no que toca aos serviços públicos, significa reduzir o cidadão a consumidor e despir o conceito jurídico de serviço público de qualquer relevância que não fosse econômica.
\end{abstract}

Trata-se, em última análise, de compreender a capacidade do Direito de conformar a realidade que o cerca, sem que dele sejam exigidas o cumprimento de tarefas que lhes são impossíveis.

Para alguns, o Direito, na qualidade de tradução normativa das posições políticas de uma sociedade, sempre prevalecerá como fonte de determinação dos demais sistemas sociais.

É propício considerar a tese adotada por Irti $(2008$, p. 1) a respeito das relações entre o universo jurídico e a economia. Para o autor,

(i) a economia, em relação a outras e diversas estruturas (coletivista, mista, etc.), é locus artificialis, e não locus naturalis; (ii) essa artificialidade deriva de uma escolha do direito, a qual, dependente de decisões políticas, confere norma à economia e a faz, de tempo em tempo, mercantil, coletivista ou mista, e assim por diante; (iii) que aquelas decisões políticas são, por si sós, mutáveis, de modo que os vários regimes da economia vêm marcados pela historicidade, e nenhum pode dizer-se absoluto e definitivo. 
Em suma, expressa o autor uma rejeição ao naturalismo econômico, ${ }^{38}$ nos termos do qual o Direito apareceria "como simples imagem ou reprodução de uma ordem que seja primeira e fora dele". (IRTI, 2008, p. 1)

Ao final, a afirmação de que o Direito tem capacidade para determinar a economia não simboliza a substituição do prestação econômica pela jurídica, tampouco a opção por determinado modelo econômico, mas a mera tradução da vontade política em normas e instituições jurídicas a serem observadas:

Atrás da antítese entre lei natural da economia - neutras, absolutas e objetivas -
e leis históricas - dependentes do querer humano - sempre se agita a luta
política, sempre se confrontam ideologias ou visões de sociedade. Conflito entre
uma e outra política, e não entre política e a-política neutralidade. Quando se
afirma que o direito determina a economia, e o mercado se resolve no estatuto de
normas, não se propõe um ou outro regime de trocas, uma ou outra disciplina da
propriedade, mas somente se recorda o elementar pressuposto de todas as
estruturas: a vontade política, traduzida em instituições jurídicas. [...] E assim -
convém sublinhar -,quando o Estado se retira da Economia, 'privatizando' bens
e empresas, não ocorre o esvaziamento da política, nem o objetivo império da
natureza, mas uma plenitude da política, daquele querer humano que escolheu
um determinado regime de propriedade e de negócios. (IRTI, 2008, p. 6 , grifos
do autor)

Em direção semelhante caminha Campilongo (2005, p. 48-49), com o apoio da teoria dos sistemas, ao afirmar que o Direito opera por meio de uma lógica própria, qualificando ações como lícitas ou ilícitas. Sua função é assegurar expectativas normativas, fato que não se confunde com o oferecimento de utilidades materiais:

\begin{abstract}
As operações do sistema jurídico admitem enlaces exclusivamente normativos. Para o sistema econômico, de outra parte, as operações próprias são conectadas em termos monetários e programáveis por preços, caso contrário, não são relevantes para a economia. No sistema jurídico, as operações ou são processáveis com base na diferença entre lícito e ilícito e programáveis em termos de normas jurídicas, ou, de modo análogo àquele que sucede na economia, não integram o Direito. Por conta disso, não pode haver dúvida quanto à relevância do regime jurídico de direito público para a conceituação de serviço púbico. Entretanto, ao lado da dimensão jurídico-formal, é no plano do funcionamento concreto do sistema normativo, isto é, na garantia das
\end{abstract}

${ }^{38}$ Conforme explica Irti (2008, p.1-2), “o naturalismo, uma vez superada a fé ou ideologia do direito natural, ocupa o terreno da economia; e como o direito natural era entendido como absoluto e imutável, então a economia de mercado seria provida daqueles caracteres e aspiraria à mesma incondicionada validade. Ainda uma vez, a "natureza" é contraposta à história dos homens e elevada à critério de condução e de juízo do direito positivo. O jusnaturalismo se representa não mais de forma teológica ou racional, mas na moderna dimensão da economia. O naturalismo, tendo por base a imutabilidade das 'leis da economia', rejeita a discordância da política, o mutável fluxo das opiniões, o instável acontecer do direito. Ele é, por sua índole, antipolítico e antijurídico. E, portanto, cria e preza a zona 'neutra', 'técnica', 'independente', onde silenciam todos os conflitos e imperam somente as 'leis do mercado' ". 
expectativas normativas geradas pelos serviços públicos, que a unidade do sistema jurídico pode ser melhor compreendida. [...]

Garantir expectativas de direitos é distinto (mas não menos importante, em especial por ser atribuição exclusiva do sistema jurídico) de realizar pagamentos, curar pessoas ou educar crianças. Uma concepção jurídica do serviço público não pode, por isso, confundir os direitos relacionados aos serviços públicos com prestações que o direito, por si, não é capaz de garantir.

Do ponto de vista do serviço público, as análises econômicas consistem em um importante fator de ponderação para o sucesso da prestação, e a isso não se opõe qualquer objeção. Ocorre que, ao lado de tais ponderações, permanece o direito como elemento determinante de opções políticas realizadas pela sociedade, cristalizadas na inserção de determinada atividade (o saneamento) em um regime de privilégios e pautado por finalidades intransponíveis: universalização, coesão social, etc.

A conjugação dos diferentes sistemas sociais relacionados nos serviços públicos não é impossível. Deveras, não se almeja aqui sustentar uma contradição intransponível entre serviços públicos como categoria jurídica e as pressões econômicas e políticas por ele sofridas. Ao contrário, a compreensão plena do serviço público como noção jurídica só é possível pela análise conjunta dos fatores econômicos e políticos que o determinam.

Todavia, não cabe ao Direito colocar-se no lugar da economia e da política. Ao regime jurídico dos serviços públicos compete a imprescindível função de criar expectativas normativas, bem como as condições institucionais para o desempenho das tarefas da economia e da política.

Se é fato que muitas vezes condições materiais se impõem como obstáculos rígidos para a universalização dos serviços (v.g., restrições do erário de muitos entes municipais), é certo que o Direito, por meio de instituições jurídicas, pode auxiliar na transformação dessa realidade por meio de sua particular atribuição de provocar e induzir comportamentos.

A gestão compartilhada do saneamento é, nesse contexto, um mecanismo jurídico colocado à disposição dos administradores para potencializar sua capacidade de ação. Esse é um dos aspectos de seu fundamento teórico e da razão de sua existência prática.

Demonstrou-se, no início deste trabalho, como o discurso em prol da sustentabilidade econômica dos serviços pautou as possibilidades de disseminação do 
saneamento. Muitos dos cidadãos remanescem não atendidos em virtude da impossibilidade de uma prestação que possa se apresentar como autossuficiente.

Nessas hipóteses, faz-se presente a figura do Poder Público, encarregado de compensar as deficiências que atores privados sozinhos não teriam disposição econômica para fazê-lo, podendo, no exercício de tal desiderato, atuar diretamente na prestação ou favorecer arranjos institucionais que facilitem ou mesmo possibilitem a participação privada no desenvolvimento dos serviços.

Sob tal perspectiva, deve ser interpretada a gestão compartilhada. Um meio institucional para incrementar a universalização do saneamento. ${ }^{39}$

A utilização de figuras como a da gestão compartilhada, que permite a reunião de esforços dos entes federados para a prestação de atividade de interesse público, é, por certo, fruto do papel cada vez mais consolidado que se atribui ao saneamento como instrumento de coesão social. Tal coesão somente se confirmará como realidade tangível se a universalização consistir em escopo fundamental a ser atingido por meio dos instrumentos de organização dos serviços públicos colocados à disposição de administradores públicos e operadores do Direito.

A exposição realizada se presta, assim, a evidenciar a lógica ou pano de fundo para compreensão da própria gestão compartilhada, fundamentada em postulados simultaneamente jurídicos, econômicos, políticos e sociais e que podem ser consolidados

\footnotetext{
${ }^{39}$ A ideia de gestão compartilhada orbita em torno da universalização do saneamento. A universalização implica "que o serviço público deve ser prestado em benefício de todos os sujeitos que se encontrem em situação equivalente, de modo indeterminado" (JUSTEN FILHO, 2004, p. 157). Nesse sentido, a união de entes federados para a prestação dos serviços almeja essencialmente a ampliação dos usuários beneficiados pelo saneamento. Somente faz sentido a conjugação de esforços se o resultado esperado for a ampliação do atendimento de maneira acessível e eficiente. A universalização é, assim, pressuposto conceitual intransponível para a compreensão de qualquer método organizacional relativo aos serviços públicos. Em interessante estudo, Coutinho (2003) demonstra as diferentes justificativas existentes para a universalização dos serviços de telecomunicações. Os argumentos traçados pelo autor podem ser aplicados com facilidade ao saneamento, especialmente no que concerne aos serviços de água e esgoto. Segundo o autor, há três fatores que justificam as ações estatais destinadas à universalização dos serviços públicos: $(i)$ a existência de externalidades positivas associadas ao atendimento do maior número possível de usuários dos serviços (saúde, meio-ambiente, etc.); (ii) a relação positiva entre investimento em infraestrutura, crescimento e desenvolvimento econômico e ainda os (iii) efeitos redistributivos da universalização (COUTINHO, 2003, p. 194). Como se vê, a universalização não é um fim em si mesmo, sendo, antes, um objetivo mediato, que permitirá que outros benefícios ou finalidades como os descritos por Coutinho sejam atingidos. A identificação dessas finalidades torna-se crucial para a operação jurídica do saneamento e para a implantação de políticas regulatórias afetas aos serviços. Em outras palavras, figuram tais finalidades como parâmetros norteadores da dos serviços públicos, atividade situada a meio caminho da caracterização como atividade econômica e como mecanismo de realização de políticas públicas.
} 
nas palavras e expressões: escala, união de capacidades, construção de alternativas técnicas, geração de expectativas normativas, criação de instituições e universalização.

Nesse contexto, o Direito assume funções específicas e que se manifestam na criação de condições normativas e institucionais para a atuação de atores públicos e privados, atribuições que não podem ser desempenhadas por qualquer outro sistema social. Essa a tarefa do sistema normativo, esse o desafio do regime jurídico dos serviços públicos no ordenamento brasileiro.

Com isso, espera-se afirmar a condição de necessidade e autonomia do sistema jurídico diante das pressões, demandas e fronteiras oriundas ou impostas por outros campos da tessitura social. Autonomia que não se confunde e nem pretende a separação e o distanciamento dos problemas e desafios colocados pela economia e pela política, sendo antes o passo inaugural a viabilizar o sistema jurídico como instrumento de mudança social.

Em essência, como norte fundamental de todo o trabalho ora empreendido, trata-se de buscar o entendimento de novos mecanismos de gestão de serviços públicos (a gestão compartilhada), sob o prisma normativo e em razão das relações deste com as dinâmicas econômica e política, sem que estas últimas subtraiam da noção de serviços públicos suas especificidades e determinantes jurídicos e sem o comprometimento do imperativo de universalização de atividades que são essenciais à existência e, acima de tudo, à coexistência humana, compreendida esta última expressão em toda a sua força. 


\section{VISÃO GERAL DOS SERVIÇOS DE SANEAMENTO BÁSICO}

Neste capítulo buscou-se uma visão abrangente, ainda que não exaustiva, do regime jurídico dos serviços de saneamento como preparação para a abordagem consistente da sua gestão compartilhada. Foram traçadas, também, as principais características físicas das atividades integrantes do saneamento, indicando aquelas em que a gestão compartilhada possa efetivamente figurar como instrumento de gestão pertinente e necessário.

A respeito do regime jurídico dos serviços, se é fato que atualmente grande parte das determinações a respeito do saneamento consta da Lei n. 11.445/2007, há que se reconhecer que é composto pela interpretação integrada de normas provenientes de origens diversas e hierarquia variada, tais como as leis que disciplinam as concessões de serviços públicos; as normas emitidas por órgãos ambientais a respeito do licenciamento e gestão dos empreendimentos ligados ao saneamento; normas produzidas por órgãos de saúde a respeito da qualidade da água; regras e ditames concernentes à outorga, uso e gestão de recursos hídricos, normas municipais sobre uso e ocupação do solo (no caso da drenagem urbana) sem mencionar, é claro, a disciplina normativa a respeito da gestão associada de serviços públicos e instituição de regiões metropolitanas. Tudo isso sem mencionar a regulação produzida pelos respectivos titulares dos serviços, que varia conforme as especificidades de cada local ou região.

Bem por isso, a melhor estratégia para conhecimento do saneamento consiste em abordar cuidadosamente as diferentes atividades dele integrantes, a fim de que não apenas suas características concretas sejam apreendidas, como também, em relação a cada tipo de serviço ou atividade, possam ser associadas normas específicas de seu regime jurídico.

Antes do exame de cada uma das atividades componentes do saneamento, convém, na qualidade de prelúdio ou introdução, descrever as linhas gerais adotadas pela Lei Nacional de Saneamento. 


\subsection{LINHAS GERAIS DO REGIME JURÍDICO DOS SERVIÇOS DE SANEAMENTO BÁSICO}

A Lei n. 11.445/2007 estabeleceu diretrizes nacionais para o saneamento básico. Por razões de coerência e organização lógica, o detalhamento de muitas das normas a respeito do regime jurídico do saneamento foi realizado no capítulo 4 deste trabalho, tarefa desempenhada sobre os auspícios da noção de gestão compartilhada.

A Lei Nacional do Saneamento encontra-se dividida em grandes temas que procuram explorar todas as dimensões normalmente envolvidas no tema dos serviços públicos. Trata, assim, do arcabouço principiológico do saneamento, delimita normas sobre o exercício da titularidade dos serviços, trata da sua prestação regionalizada, do seu planejamento, da regulação dos serviços, dos aspectos econômicos, sociais e técnicos envolvidos na sua concretização, da participação de órgãos colegiados no controle social e, por fim, da política federal de saneamento.

$\mathrm{O}$ arcabouço principiológico do saneamento apresenta, como era de se esperar, muitos pontos de contato com o regime dos serviços públicos em geral. Assim é que o imperativo de utilização de tecnologias apropriadas descrito no inciso VIII do art. $2^{\circ}$ aproxima-se da noção da atualidade já constante da Lei n. 8.987/95. Outros, como a eficiência (art. $2^{\circ}$, VII, da LNS), têm matriz constitucional e sua aplicação abarca toda a Administração Pública. Do mesmo modo, o controle social (art. $2^{\circ}, \mathrm{X}$ ) dos serviços decorre da participação popular na gestão administrativa cujo fundamento é também constitucional. $^{40}$

Um avanço significativo refletido nos princípios descritos e que permeará toda a Lei Nacional do Saneamento é a atuação concatenada das atividades integrantes do saneamento.

$\mathrm{O}$ art. $2^{\circ}$, II e VI, da n. 11.445/2007 traz como princípios a reger o saneamento a integralidade, "compreendida como o conjunto de todas as atividades e componentes de

${ }^{40}$ Informa a Constituição: “Art. 37 [...] § $3^{\circ}$ A lei disciplinará as formas de participação do usuário na administração pública direta e indireta, regulando especialmente: I - as reclamações relativas à prestação dos serviços públicos em geral, asseguradas a manutenção de serviços de atendimento ao usuário e a avaliação periódica, externa e interna, da qualidade dos serviços; II - o acesso dos usuários a registros administrativos e a informações sobre atos de governo, observado o disposto no art. $5^{\circ}$, X e XXXIII; III - a disciplina da representação contra o exercício negligente ou abusivo de cargo, emprego ou função na administração pública." 
cada um dos diversos serviços de saneamento básico, propiciando à população o acesso na conformidade de suas necessidades e maximizando a eficácia das ações e resultados" e a articulação dos serviços com "as políticas de desenvolvimento urbano e regional, de habitação, de combate à pobreza e de sua erradicação, de proteção ambiental, de promoção da saúde e outras de relevante interesse social voltadas para a melhoria da qualidade de vida".

A Lei Nacional de Saneamento recebeu críticas por tratar simultaneamente de atividades estrutural e economicamente díspares, mas tem o mérito de oferecer sistematicidade a questões tratadas de forma autônoma e desconexa até então.

O abastecimento de água, a coleta e o tratamento de esgoto, a limpeza urbana e a coleta e o tratamento de resíduos e a drenagem pluvial são ações afins e que apresentam interferências recíprocas. Seu profundo efeito no meio ambiente, na saúde pública e, em última análise, sua contribuição para o bem-estar humano as aproximam.

As diferenças entre os serviços não escondem o fato de que os problemas sob sua tutela apresentam um substrato comum e cuja solução é necessariamente integrada (nesse sentido também o disposto nos incisos III e IV do art. $2^{\circ}$ da lei).

No que toca à titularidade, a lei optou por tratá-la de forma genérica, sem especificar nominalmente os entes federados detentores dos serviços (as discussões em torno da titularidade dos serviços serão travadas no capítulo 4 do trabalho). Por ora é relevante pontuar a delegabilidade pelos titulares das atribuições de organização, regulação, fiscalização e prestação do saneamento ( $\operatorname{art.} 8^{\circ}$ ).

Importante prerrogativa do titular consiste na formulação da respectiva política pública de saneamento, por meio da elaboração de planos e do exercício de competências típicas do poder concedente dos serviços como o controle de sua delegação e fiscalização, a garantia das normas de saúde pública, a fixação dos direitos e os deveres dos usuários, dentre outros temas $\left(\operatorname{art.} 9^{\circ}\right)$.

Destaque-se que uma das evoluções trazidas pela lei se situa na exigência de celebração de contrato como requisito para a prestação de serviços por entidade que não integre a administração do titular (art. 10). Não mais serão utilizados os convênios e outros instrumentos precários que tanto influenciaram historicamente a gestão do setor. Os convênios foram o principal instrumento de relacionamento entre as empresas estaduais de saneamento e os Municípios, muitos dos quais ainda se encontram em vigor. 
A validade dos contratos depende da existência de plano de saneamento básico; de estudos que comprovem a viabilidade técnica e econômico-financeira da prestação universal e integral dos serviços, a existência de um sistema regulatório composto por normas e entidade de regulação (art. 11).

No que concerne ao plano de saneamento básico, serão editados pelos titulares e conterão, para um período de quatro anos, os diagnósticos, os objetivos, as metas, as ações emergenciais e de contingência e os mecanismos de avaliação dos serviços (art. 19).

O sistema regulatório previsto, seguindo as grandes linhas do funcionamento da atividade de regulação no direito brasileiro, baseia-se na independência decisória do ente regulador, a ser dotado ainda de autonomia administrativa, orçamentária e financeira. Suas decisões devem se caracterizar pela transparência, tecnicidade, celeridade e objetividade (art. 21).

Constitui objetivo da regulação estabelecer padrões e normas para a adequada prestação dos serviços e para a satisfação dos usuários; garantir o cumprimento das condições e metas estabelecidas; prevenir e reprimir o abuso do poder econômico; e definir tarifas que assegurem tanto o equilíbrio econômico e financeiro dos contratos como a modicidade tarifária (art. 22).

A preocupação com a sustentabilidade econômica dos serviços é uma constante na Lei n. 11.445/2007, que chegou a delimitar os diferentes tipos remuneratórios para cada atividade, ${ }^{41}$ assim como a sua adequação e integração aos objetivos regulatórios do sistema e às características da comunidade local abrangida pela prestação, notadamente à capacidade de pagamento dos usuários (nesse sentido, os arts. 29 e 30 da LNS).

Nesse contexto, o regime de financiamento dos serviços, alinhado ou não a uma política de subsídios, pode influenciar fortemente na redistribuição de renda da população (serviço público como política pública), na universalização do saneamento, na criação de incentivos para a economia, no uso adequado de recursos hídricos e na proteção do meio ambiente, bem como tem efeito direto na eficiência e produtividade dos

\footnotetext{
41 “Art. 29. Os serviços públicos de saneamento básico terão a sustentabilidade econômico-financeira assegurada, sempre que possível, mediante remuneração pela cobrança dos serviços:

I - de abastecimento de água e esgotamento sanitário: preferencialmente na forma de tarifas e outros preços públicos, que poderão ser estabelecidos para cada um dos serviços ou para ambos conjuntamente; II - de limpeza urbana e manejo de resíduos sólidos urbanos: taxas ou tarifas e outros preços públicos, em conformidade com o regime de prestação do serviço ou de suas atividades;

III - de manejo de águas pluviais urbanas: na forma de tributos, inclusive taxas, em conformidade com o regime de prestação do serviço ou de suas atividades."
} 
prestadores e na modernidade e renovação das técnicas de prestação (ver arts. 31 a 42 da LNS).

A Lei Nacional de Saneamento dedica-se, ainda, a traçar a vinculação dos serviços a padrões técnicos e de qualidade, relevando preocupações com o licenciamento ambiental das instalações do saneamento (arts. 43 e 44) e com a necessária ligação de toda edificação urbana de caráter permanente às redes de água e esgoto, ressalvadas as disposições em contrário das normas do titular, da entidade reguladora ou dos órgãos do meio ambiente (art. 45).

Como se vê, a Lei n. 11.445/2007 criou um grande quadro referencial a respeito do saneamento, o qual será complementado pelos titulares dos serviços no desempenho das atividades de regulação e gestão da prestação.

Empreendida a compreensão das linhas gerais trazida pela Lei Nacional de Saneamento, passa-se à delimitação da abrangência e características específicas dos serviços.

\subsection{ABRANGÊNCIA}

A abrangência do saneamento concerne à descrição das atividades e serviços dele integrantes. Com base na definição dos elementos constitutivos do saneamento será possível evidenciar as distintas características estruturais de cada atividade e o tratamento jurídico-organizacional pertinente a cada uma delas.

Pode-se, como Marques Neto (2005a, p. 24), considerar o saneamento básico como espécie do gênero saneamento ambiental, o qual abrangeria ainda a limpeza urbana e o manejo de águas pluviais em áreas urbanas.

Em um sentido aproximado, Heller (2006, p. 33) apresenta a definição dada pela Fundação Nacional de Saúde (FUNASA), segundo a qual o saneamento ambiental corresponde ao

conjunto de ações socioeconômicas que têm por objetivo alcançar níveis de salubridade ambiental, por meio de abastecimento de água potável, coleta e disposição sanitária de resíduos sólidos, líquidos e gasosos, promoção da disciplina sanitária de uso do solo, drenagem urbana, controle de doenças 
transmissíveis e demais serviços e obras especializadas, com a finalidade de proteger e melhorar as condições de vida urbana e rural.

A amplitude acima conferida ao termo saneamento ambiental é identificada por Justen Filho (2005a, p. 206) como o próprio conteúdo dos serviços de saneamento básico:

\begin{abstract}
Mais ainda, não é possível aludir propriamente a 'serviços públicos de saneamento básico' como um conceito jurídico unitário - eis que existem serviços públicos específicos que desempenham função relevante para a promoção de um saneamento básico adequado. Assim, pode aludir-se à captação, transporte, tratamento e distribuição de água, à coleta, interceptação, transporte, tratamento e destinação final, inclusive eventual reuso de dejetos líquidos, à coleta, transporte e processamento de dejetos sólidos e assim por diante. Até se poderia incluir, nesse conjunto, também os serviços relacionados ao manejo de águas pluviais.
\end{abstract}

Neste trabalho, adotar-se-á como pressuposto conceitual uma concepção ampla dos serviços de saneamento básico, de forma a englobar a captação, o transporte, o tratamento e a distribuição de água, a coleta, a interceptação, o transporte, o tratamento e a destinação final de dejetos líquidos, a coleta, o transporte e o processamento de dejetos sólidos, bem como o manejo de águas pluviais.

Tal dimensão não diverge da veiculada pela Lei n. 11.445/2007, que estabelece as diretrizes nacionais para o tema. ${ }^{42}$ Destaque-se que o objetivo da norma foi abarcar situações que envolvessem a coletividade, e não soluções individuais de saneamento tal como dispõe o art. $5^{\circ}$ dessa lei: “Art. $5^{\circ}$ Não constitui serviço público a ação de saneamento executada por meio de soluções individuais, desde que o usuário não dependa de terceiros para operar os serviços, $[\ldots .] ”$.

\footnotetext{
${ }^{42}$ É o que decorre da leitura do inciso do inciso I do art. $3^{\circ}$ da Lei n. 11.445/2007:

"Art. $3^{\circ}$ Para os efeitos desta Lei, considera-se:

I - saneamento básico: conjunto de serviços, infra-estruturas e instalações operacionais de:

a) abastecimento de água potável: constituído pelas atividades, infra-estruturas e instalações necessárias ao abastecimento público de água potável, desde a captação até às ligações prediais e respectivos instrumentos de medição;

b) esgotamento sanitário: constituído pelas atividades, infra-estruturas e instalações operacionais de coleta, transporte, tratamento e disposição final adequados dos esgotos sanitários, desde as ligações prediais até o seu lançamento final no meio ambiente;

c) limpeza urbana e manejo de resíduos sólidos: conjunto de atividades, infra-estruturas e instalações operacionais de coleta, transporte, transbordo, tratamento e destino final do lixo doméstico e do lixo originário da varrição e limpeza de logradouros e vias públicas;

d) drenagem e manejo das águas pluviais urbanas: conjunto de atividades, infra-estruturas e instalações operacionais de drenagem urbana de águas pluviais, de transporte, detenção ou retenção para o amortecimento de vazões de cheias, tratamento e disposição final das águas pluviais drenadas nas áreas urbanas;

$[\ldots] . "$
} 
Em comum, as atividades do saneamento possuem uma estreita relação com a questão ambiental (pois sua adequada implantação é condição para a significativa redução dos impactos da ação humana na natureza), com a proteção da saúde pública, ao evitar a disseminação de doenças associadas a condições sanitárias ruins, e com a gestão sustentável do sistema de recursos hídricos. ${ }^{43}$

Embora se reconheça que o saneamento não seja uma necessidade apenas urbana, é nesse espaço que os sintomas de um sistema inadequado são perceptíveis em um contexto de paroxismo.

A urbanização e aglomeração humana das cidades são os pontos de tangenciamento entre todas as atividades compreendidas no saneamento e a elas estão associados um sem número de problemas. (MONTENEGRO; TUCCI, 2005, p. 9-10)

A expansão irregular da população pode ocorrer sobre áreas de mananciais de abastecimento humano, prejudicando a sustentabilidade hídrica das cidades. A população de baixa renda tende a ocupar áreas de risco de encostas e áreas de inundações ribeirinhas, agravando os efeitos das chuvas e enchentes. A impermeabilização derivada da expansão urbana e a canalização dos rios também dificultam a absorção e a drenagem das águas pluviais.

O aumento da densidade habitacional repercute no aumento de demanda de água e no aumento da carga de poluentes sem tratamento lançada nos rios próximos às cidades.

Com efeito, um problema recorrente nas áreas urbanas é o despejo nos rios dos esgotos domésticos não tratados. É comum, ainda, nos períodos chuvosos, o lançamento dos esgotos pluviais nas águas urbanas, transportando grande quantidade de poluição orgânica e de metais (poluição difusa).

Constata-se, em muitos casos, a contaminação das águas subterrâneas por despejos industriais e domésticos em razão das fossas sépticas e dos vazamentos dos sistemas de esgoto sanitário e pluvial, bem como em decorrência de depósitos irregulares de resíduos sólidos urbanos, que contaminam as águas superficiais e subterrâneas. ${ }^{44}$

\footnotetext{
${ }^{43}$ Importante destacar que, como serviço público, o saneamento não se confunde com o sistema de gestão de recurso hídricos disciplinado pela Lei n. 9.433/97, sendo, antes, uma das atividades que se vale desses recursos escassos para seu funcionamento (art. $4^{\circ}$ da Lei n. 11.445/2007).

${ }^{44}$ Montenegro e Tucci (2005, p. 11) informam, ainda, que as principais condições de contaminação dos aquíferos urbanos devem-se a "aterros sanitários, [que] contaminam as águas subterrâneas pelo processo natural de precipitação e infiltração. Assim, convém evitar que sejam construídos aterros sanitários em
} 
Percebe-se que, além da questão urbana, também os recursos hídricos encontram-se no centro das discussões sobre saneamento. Segundo Turolla e Ohira (2006, p. 20), são os recursos hídricos que recebem carga poluidora decorrente da destinação inadequada de todos os sistemas do saneamento.

Montenegro e Tucci (2005, p.13-14) sintetizam bem a interface entre as atividades do saneamento:

(i) entre o abastecimento urbano de água e outros sistemas, contatam-se os seguintes pontos de relação: a) esgotos sanitários, que contaminam os pluviais e, em consequência, os rios onde deságuam; b) depósitos de resíduos sólidos (como aterros) podem contaminar as áreas de mananciais e c) as inundações podem interromper o funcionamento do sistema de abastecimento de água;

(ii) entre o esgotamento sanitário e a drenagem urbana, os pontos de contatos ocorrem: a) quando a rede de coleta é mista (a mesma rede para esgoto e águas pluviais), verifica-se o comportamento imprevisível do funcionamento do sistema nos períodos sem e com chuva; e b) quando a rede de coleta é separadora (redes pluvial e cloacal distintas), interferências decorrentes de vazamentos do esgoto sanitário na rede de drenagem podem tornar ineficiente o funcionamento do sistema;

(iii) no que concerne às interações entre o manejo de águas pluviais, a gestão de resíduos sólidos e o esgotamento sanitário, tem-se que um sistema de coleta e limpeza de resíduos ineficiente causa grande prejuízo para a drenagem urbana, em razão da obstrução dos condutos, dos canais e dos riachos urbanos pelos resíduos não recolhidos. Acrescente-se a erosão urbana, que modifica o sistema de drenagem, podendo comprometer ainda o sistema de esgotamento sanitário.

Amalgamadas por objetivos coincidentes (higiene, prevenção sanitária, proteção da saúde pública e ambiental, etc.), pelos aspectos comuns de seu regime jurídico, lastreados, sobretudo, na Lei Nacional de Saneamento, e pelos inúmeros pontos de contato

áreas de recarga e deve-se procurar escolher as áreas com baixa permeabilidade. Os efeitos da contaminação nas águas subterrâneas devem ser examinados quando da escolha do local do aterro; grande parte das cidades brasileiras utiliza fossas sépticas como destino final do esgoto. Esse sistema tende a contaminar a parte superior do aqüífero. Essa contaminação pode comprometer o abastecimento de água urbana quando existe comunicação entre diferentes camadas dos aqüíferos, em virtude de percolação e de perfuração inadequada dos poços artesianos; a rede de drenagem pluvial pode contaminar o solo em decorrência de perdas de volume no seu transporte e até por entupimento de trechos da rede que pressionam a água contaminada para fora do sistema de condutos". 
e influência recíproca acima destacados, há que se reconhecer que as atividades integrantes do saneamento são distintas entre si, tanto do ponto de vista da sua implantação e operação técnica quanto no que concerne à incidência de certas normas, peculiares apenas a algumas das atividades do setor.

A compreensão do marco regulatório integrado do saneamento deverá observar as particularidades estruturais de cada tipo de atividade, sob pena de contradições graves.

A coleta de resíduos sólidos e a drenagem são, por exemplo, atividades nas quais as influências do monopólio natural, custos irrecuperáveis e verticalização, embora existentes, são de menor relevância se comparadas com a distribuição de água e a coleta de esgoto. (MOTTA, 2007, p. 191)

Das diferenças estruturais das atividades integrantes do saneamento decorrerá tratamento distinto a respeito das possibilidades de seu financiamento (taxas, tarifas, impostos, participação da iniciativa privada, etc.) e regime de execução e gestão dos eventuais contratos firmados com particulares para sua prestação.

O conhecimento das atividades componentes dos serviços indicará as possibilidades de aplicação de instrumentos de gestão como a concessão ou a prestação direta dos serviços e dos mecanismos de gestão compartilhada.

Enfim, sem prejuízo da afirmação de um regime normativo comum entre as atividades em pauta, representado pela própria Lei n. 11.445/2007, as distinções entre as atividades integrantes do saneamento serão aqui exploradas para permitir uma percepção mais acurada de sua concretização no contexto da prestação compartilhada. Mais ainda, precisará as atividades que, contemporaneamente, são enquadradas como serviço público, delineando com maior precisão o objeto de estudo. A título exemplificativo, pode-se citar uma infinidade de atividades relacionados aos resíduos sólidos que consistem, atualmente, em atividades privadas, sob responsabilidade, portanto, dos particulares geradores dos resíduos. É o que se demonstra a seguir. 


\subsubsection{Os serviços de água e esgoto}

Os serviços de água e esgoto são descritos no art. $3^{\circ}$ da Lei n. 11.445/2007. Envolvem o abastecimento de água potável: “constituído pelas atividades, infra-estruturas e instalações necessárias ao abastecimento público de água potável, desde a captação até as ligações prediais e respectivos instrumentos de medição" e o esgotamento sanitário: "constituído pelas atividades, infra-estruturas e instalações operacionais de coleta, transporte, tratamento e disposição final adequados dos esgotos sanitários, desde as ligações prediais até o seu lançamento final no meio ambiente".

Nos serviços de água e esgoto é possível visualizar o ciclo ambiental completo do uso da água, desde sua retirada dos mananciais, entrega aos usuários, utilização e retorno na forma de esgoto sanitário. Daí a estreita relação com a utilização de recursos hídricos, os quais, embora não integrem o saneamento básico nos termos do art. $4^{\circ}$ da Lei n. 11.445/2007, somente serão utilizados com observância da outorga de direito de uso nos termos da Lei Federal n. 9.433/1997 (parágrafo único do art. $4^{\circ}$ da LNS). ${ }^{45}$

Turolla (1999, p. 7) esclarece que a água é um produto homogêneo e de uso específico. Nesse contexto, os fatores principais de crescimento da demanda pela água se concentram no crescimento vegetativo da população e no incremento da renda (maior renda incentiva condutas como irrigação de jardins e lavagem de automóveis).

\footnotetext{
${ }^{45}$ O regime estabelecido pela Lei n. 9.433/1997 apresenta objetivos bem delineados: busca tratar os recursos hídricos como bens de natureza pública e, em razão de seu caráter limitado, sujeitá-los a um planejamento que possibilite o seu uso racional e equilibrado e que privilegie as necessidades humanas. Tais premissas restam claras na lei (art. $1^{\circ}$ ): "I - a água é um bem de domínio público; II - a água é um recurso natural limitado, dotado de valor econômico; III - em situações de escassez, o uso prioritário dos recursos hídricos é o consumo humano e a dessedentação de animais; IV - a gestão dos recursos hídricos deve sempre proporcionar o uso múltiplo das águas; V - a bacia hidrográfica é a unidade territorial para implementação da Política Nacional de Recursos Hídricos e atuação do Sistema Nacional de Gerenciamento de Recursos Hídricos; VI - a gestão dos recursos hídricos deve ser descentralizada e contar com a participação do Poder Público, dos usuários e das comunidades."

Bem por isso, a lei em comento estabelece mecanismos de gestão e planejamento (planos de recursos hídricos a serem elaborados por bacia hidrográfica, Estado e País - arts. $6^{\circ}$ a $8^{\circ}$ ) e de controle qualitativo e quantitativo do uso da água, tal como o regime de outorga de direitos de uso de recursos hídricos, condição para a aplicação da água no saneamento básico: "Art. 12. Estão sujeitos a outorga pelo Poder Público os direitos dos seguintes usos de recursos hídricos: I - derivação ou captação de parcela da água existente em um corpo de água para consumo final, inclusive abastecimento público, ou insumo de processo produtivo; II - extração de água de aqüífero subterrâneo para consumo final ou insumo de processo produtivo; III - lançamento em corpo de água de esgotos e demais resíduos líquidos ou gasosos, tratados ou não, com o fim de sua diluição, transporte ou disposição final; IV - aproveitamento dos potenciais hidrelétricos; V - outros usos que alterem o regime, a quantidade ou a qualidade da água existente em um corpo de água." (Grifos nossos)
} 
Do ponto de vista estrutural, os serviços de abastecimento de água e esgotamento sanitário apresentam custos fixos elevados.

Em muitos casos, os elevados custos associados à implantação da infraestrutura (sunk costs) tornam indesejável a multiplicação de redes e a existência de distintos prestadores. Note-se que os ativos dos serviços de água e esgoto, além de implicarem investimento inicial elevado, sofrem profunda desvalorização após sua instalação, dada a especificidade de funções a que o sistema se presta.

Bem por isso é comum a ponderação de que os serviços de água e esgoto configuram um exemplo clássico de monopólio natural, em que a competição é inviável pela impossibilidade de duas redes de serviços distintas competindo pelo mesmo mercado (SALOMÃO FILHO, 2002a, p. 201), fato potencializado por ser a água um bem imprescindível à sobrevivência humana, apresentando uma elasticidade-preço de demanda baixa. $^{46}$

Especificando o afirmado, Turolla expõe que os custos fixos elevados impõem um obstáculo elevado a investimentos. Os custos fixos em saneamento incluiriam a construção e a manutenção de reservatórios, plantas de tratamento de água e de esgotos, tubulação, equipamentos de medição de consumo e outros.

Balh e Linn (1992, apud TUROLLA, 1999, p. 8) inserem na categoria de custos incrementais da produção de água os custos de curto prazo de operação e manutenção, como materiais de tratamento, energia para bombeamento e desgaste das instalações, e ainda a parcela referente aos custos de mão de obra.

Turolla (1999, p. 6-8) acrescenta que a indústria do saneamento apresenta, na sua maior parte, caráter monoprodutor. Em outras palavras, as redes de água e esgoto têm destinação exclusiva, diferentemente do setor de telecomunicações, no qual se constatam características multiprodutoras. Com efeito, a possibilidade de multiprodução somente ocorre no primeiro estágio da captação da água bruta, em que os recursos hídricos têm importantes usos alternativos, como a produção de energia elétrica e a irrigação.

\footnotetext{
${ }^{46}$ A respeito do conceito de elasticidade-preço da demanda: “A lei da demanda afirma que uma queda no preço de um bem aumenta a quantidade demandada dele. A elasticidade-preço da demanda mede o quanto a quantidade demandada reage a uma mudança no preço. A demanda por um bem é chamada elástica se a quantidade demandada responde substancialmente a mudanças no preço. Diz-se que a demanda por um bem é inelástica se a quantidade demandada responde pouco a mudanças no preço". (MANKIW, 2005 p. 90)
} 
Argumentos de eficiência econômica exigiriam, em muitos casos, a atuação em larga escala por parte do prestador como forma de incrementar seus rendimentos e fazer com que os serviços adquiram sua plena potencialidade, isto é, seu grau de concentração ótimo. Os aspectos negativos do monopólio deveriam ser compensados por uma estrutura regulatória eficiente:

Os custos fixos elevados produzem um dilema entre eficiência produtiva e eficiência alocativa. Dada a estrutura de monopólio natural, a maior eficiência produtiva pode ser conseguida por meio da operação de um produtor único. Entretanto, as distorções alocativas resultantes do poder de monopólio precisam ser controladas por algum mecanismo.

Eliminando-se pelo critério de eficiência produtiva a possibilidade de competição direta, a obtenção de eficiência alocativa requer o emprego de competição pelo direito à franquia para servir um determinado mercado, a chamada Competição de Demsetz, ou ainda um mecanismo de regulação. $\mathrm{Na}$ prática, é possível combinar as duas alternativas, com a realização de leilões pela franquia e o estabelecimento de mecanismos de regulação.

A especificidade do capital empregado no setor de saneamento é inibidora do investimento, na medida em que o valor de revenda dos ativos se reduz fortemente após o investimento ter sido feito. Isso é ainda mais grave por se tratar de um setor com volume de investimento requerido bastante superior à média dos demais serviços públicos. No caso de propriedade privada dos ativos, o poder de barganha entre o proprietário privado e o governo pode mudar radicalmente após o investimento ser feito. (TUROLLA, 2006, p. 21)

A caracterização dos serviços de água e esgoto como monopólio natural é acentuada pelo fato de que, sendo lentas as evoluções da renda da população, haveria forte incentivo para a expansão geográfica das atividades por parte de empresas operadoras como meio para consecução de maiores lucros. Isso sem mencionar a relativa estagnação tecnológica verificada no setor. A linha evolutiva do desenvolvimento tecnológico nos serviços públicos é evidenciada por Turolla (2006, p. 23):

O setor de saneamento é caracterizado por baixo dinamismo tecnológico, o que perpetua a característica de monopólio natural. De acordo com William Shepherd, o ciclo de vida se dá em quatro estágios:

1. Início - o sistema é inventado, sendo em geral protegido por uma patente. Esse é um período geralmente curto, mas é decisivo para a forma futura do sistema. No caso da eletricidade, por exemplo, considera-se que este primeiro estágio durou uma década e meia, entre 1870 e 1885 . Para o telefone, a duração foi de meia década, entre 1875 e 1880. Já para a aviação, este período compreende os cinco anos iniciados em 1920.

2. Crescimento - o sistema é criado e cresce, normalmente tomando o lugar de um serviço antigo, como no caso em que os ônibus substituíram os bondes, ou do telefone que suplantou o telégrafo. No caso do telefone, esse segundo estágio durou de 1880 até a metade do século XX. Nesse estágio, as economias de escala são muito intensas. 
3. Maturidade - o sistema cresce e se torna completo em termos tanto de tecnologia quanto de saturação de mercado. As economias de escala tornam-se cada vez menos significativas nesse estágio, enquanto novas tecnologias costumam ameaçar partes lucrativas do mercado.

4. Reversão para condições favoráveis à competição - o sistema reverte para o processo competitivo convencional, deixando de ser um serviço público e perdendo suas características de monopólio natural.

O saneamento se encontraria no estágio 3 descrito, induzindo à conclusão de que, por muito tempo, permanecerá como um monopólio natural, sobretudo no que toca às redes de água e de esgoto.

Com o apoio de Heller (2006, p. 73-78) é possível visualizar as unidades estruturais integrantes de sistemas de abastecimento de água e sua inegável interconexão:

(i) captação de água: trata-se da estrutura que retira água do manancial (fonte de água) para posterior distribuição aos usuários. A estrutura de captação deve ser adaptada às características do manancial utilizado (o manancial pode ser subterrâneo ou não confinado, subterrâneo confinado, superficial sem acumulação, superficial com acumulação e água de chuva). A captação esta sujeita, ainda, a variações sazonais de vazão influenciadas pelo regime de chuvas da região;

(ii) adução: destina-se a transportar a água, interligando unidades de captação, tratamento, estações elevatórias, reservação e rede de distribuição;

(iii) estações elevatórias: estruturas necessárias ao transporte da água para níveis topográficos mais elevados. Impulsionam a água para regiões de maior altitude o que torna sua existência dependente das condições de relevo verificadas em cada sistema;

(iv) tratamento: atividade que torna a água bruta compatível com os padrões de potabilidade estabelecidos como condição para o consumo humano (os padrões de potabilidade constam da Portaria n. 518 do Ministério da Saúde);

(v) reservatórios: estruturas que armazenam a água e realizam a compensação entre a vazão de produção (oriunda da captação) e vazão de consumo da água (as quais variam constantemente durante períodos do dia ou mesmo do ano). Os reservatórios variam quanto à sua posição no terreno (apoiado, elevado, semi-enterrado, enterrado) e quanto ao seu posicionamento em relação à rede de distribuição (montante ou jusante).

(vi) rede de distribuição: integrada por tubulações, conexões e peças especiais: responsável por fazer com que a água atinja residências e demais unidades consumidoras. 
No que toca ao esgoto, seu manejo pode ser divido em três fases fundamentais:

(i) coleta dos esgotos nas unidades habitacionais e demais estabelecimentos;

(ii) tratamento, a abranger: uma fase preliminar que envolve a separação dos sólidos por meio de processos de assentamento; o tratamento secundário, no qual são empregados microorganismos para decompor os materiais orgânicos contidos no esgoto e o tratamento terciário, eventualmente necessário para atender a certos padrões de qualidade, dependendo do conteúdo do esgoto em tratamento.

(iii) disposição final nos corpos hídricos.

Para além da compreensão estrutural dos serviços de água e esgoto, o relevante nesse momento é destacar que, em razão de suas características, tais atividades são, por excelência, o campo de atuação preponderante da gestão compartilhada. Sua constituição em rede e a inegável tendência econômica para formação de monopólio natural aproximam esses serviços da ideia de prestação conjugada pelos entes federados, permitindo uma escala ideal de fornecimento.

Com efeito, a união de dois ou mais Municípios sob os auspícios de um mesmo prestador poderiam resultar em condições econômicas ideais para a sustentabilidade das atividades em pauta.

Importante ponderar que a cadeia completa dos serviços de distribuição de água e coleta e tratamento de esgoto não deve, necessariamente, ser considerada um bloco indivisível de atividades, que devem ser prestadas por um único operador, responsável por todos os atos dos serviços, desde a captação de água até a disposição final do esgoto.

$\mathrm{O}$ art. 12 da Lei n. 11.445/2007 indica claramente a possibilidade de que em um mesmo ciclo de atividades possam conviver inúmeros prestadores. Exige o dispositivo que, "nos serviços públicos de saneamento básico em que mais de um prestador execute atividade interdependente com outra, a relação entre elas deverá ser regulada por contrato e haverá entidade única encarregada das funções de regulação e de fiscalização".

A desagregação de atividades nos serviços públicos e sua entrega a prestadores diferentes permitem a diversificação dos modelos de implantação de infraestrutura, oportunizando desenhos operacionais e econômicos mais flexíveis.

Note-se que a menção do art. 12 a atividades interdependentes comprova que se trata de ações conectadas, vinculadas umas às outras em uma cadeia ou rede na qual cada parte depende da precedente e da subsequente para seu funcionamento perfeito, mas 
que podem ser desenvolvidas por distintos operadores. Bem por isso, não se pretende defender de forma absoluta a necessidade da gestão compartilhada para os serviços de água e esgoto na sua integralidade.

Existem frações dos serviços que possuem caráter inequivocamente local, como a distribuição de água e a coleta do esgoto, caracterizadas por redes capilarizadas diretamente conectadas aos prédios urbanos. Trata-se das atividades diretamente vinculadas aos usuários e que permitem seu acesso às utilidades públicas.

Outros serviços, como a captação de água e a disposição final dos esgotos (associados ou não à infraestrutura de tratamento), podem ser desempenhados com maior eficiência em um contexto territorial mais abrangente, abarcando dois ou mais Municípios, seja porque tais atividades se situam no extremo oposto da cadeia de prestação (captação de água por atacado), demandando maior escala para sua viabilização; seja em razão das circunstâncias concretas de determinada localidade (notadamente características geográficas como a ausência de corpos hídricos em determinados Municípios para a captação de água ou a disposição final do esgoto tratado).

Com isso, permitir-se-á o acesso de certas localidades a mananciais ou corpos hídricos inexistentes nas suas proximidades. Frise-se que tais atividades não possuem, obrigatoriamente, caráter regional (já que, em tese, é possível sua prestação integral dentro de um único Município).

O resultado das avaliações técnicas, ambientais e econômicas influenciará a adoção ou não de um sistema de gestão compartilhada que permita, pela maior abrangência territorial (quando dois ou mais Municípios estiverem envolvidos na gestão), a constituição de grandes sistemas em rede, típicos do monopólio natural. Mais uma vez não custa asseverar que também apenas os estudos técnicos e econômicos serão capazes de identificar o grau ótimo de concentração em um mesmo operador ou a necessidade da regionalização territorial dos serviços. 


\subsubsection{A limpeza urbana e coleta e destinação final de resíduos sólidos}

A limpeza urbana e o manejo de resíduos sólidos estão caracterizados no art. $3^{\circ}$, inciso I, alínea "c" da Lei Nacional de Saneamento como o "conjunto de atividades, infra-estruturas e instalações operacionais de coleta, transporte, transbordo, tratamento e destino final do lixo doméstico e do lixo originário da varrição e limpeza de logradouros e vias públicas".

Essa lei não utiliza uma conceituação clara a respeito dos diferentes tipos de resíduos existentes. Menciona o lixo doméstico e o lixo originário da varrição e limpeza de logradouros e vias públicas no art. $3^{\circ}$, conforme demonstrado, e nos arts. $6^{\circ}$ e $7^{\circ}$ traz a expressão "resíduo sólido urbano" como gênero que aparentemente abarca as duas espécies anteriores.

Note-se que o art. $5^{\circ}$ da lei afasta expressamente da abrangência dos serviços públicos de saneamento as ações de caráter individual e medidas de responsabilidade privada:

Art. $5^{\circ}$ Não constitui serviço público a ação de saneamento executada por meio de soluções individuais, desde que o usuário não dependa de terceiros para operar os serviços, bem como as ações e serviços de saneamento básico de responsabilidade privada, incluindo manejo de resíduos de responsabilidade do gerador. (Grifos nossos)

A doutrina e os textos especializados apresentam uma classificação que auxiliará a compreensão das opções realizadas pelo legislador ordinário.

A Norma Brasileira Registrada (NBR) n. 10.004, de 1987, conceitua os resíduos como aqueles

nos estados sólidos e semi-sólido, que resultam de atividades da comunidade de origem industrial, agrícola, de serviços e de varrição. Ficam incluídos nesta definição os lodos provenientes de sistemas de tratamento de água, aqueles gerados em equipamentos e instalações de controle de poluição, bem como determinados líquidos cujas particularidades tornem inviável seu lançamento na rede pública de esgoto ou corpos d'água, ou exijam, para isso, soluções técnica e economicamente inviáveis, em face à melhor tecnologia disponível.

Araújo (2008, p. 38) bem expõe a possibilidade de classificação dos resíduos segundo sua natureza física (seco ou molhado); composição química (matéria orgânica ou 
inorgânica), os riscos provocados ao meio ambiente e à saúde pública ${ }^{47}$ e quanto à sua origem. Nesse último caso, os resíduos podem ser classificados como:

(i) domiciliar (também chamado residencial ou doméstico);

(ii) comercial (proveniente de escritórios, órgãos públicos, cinemas, teatros, etc.);

(iii) industrial;

(iv) serviços de saúde (gerados por hospitais, casas de saúde, maternidades, postos de saúde, dentre outros);

(v) portos, aeroportos e terminais rodoviários;

(vi) agrícola;

(vii) construção civil;

(viii) limpeza urbana (logradouros, praias, feiras, eventos, decorrentes de capina, raspagem e varrição);

(ix) abatedouros, matadouros, estábulos e serviços congêneres.

Atualmente, não existe lei ordinária federal que discipline à exaustão e de maneira definitiva os diferentes tipos de resíduos e os responsáveis pelo seu manejo. ${ }^{48}$

${ }^{47}$ Segundo a Associação Brasileira de Normas Técnicas (ABNT), a caracterização de um resíduo sólido depende da sua avaliação qualitativa e quantitativa. Para tanto, são investigados os parâmetros que permitam a identificação de seus componentes principais e a presença de características que indiquem se o resíduo deve ser qualificado como perigoso por apresentar inflamabilidade, corrosividade, reatividade, toxicidade e patogenicidade. Essas características devem nortear os cuidados no gerenciamento do resíduo sólido. A já citada NBR n. 10.004 informa, ainda, que a periculosidade de um resíduo é medida em função de suas características físicas, químicas ou infectocontagiosas que apresentem risco à saúde pública, provocando mortalidade, incidência de doenças ou acentuando seus índices e risco ao meio ambiente, quando o resíduo for gerenciado de forma incorreta. Assim, os resíduos são classificáveis em Classe I Perigosos, Classe II - Não Perigosos, Classe II A - Não Inertes e Classe II B - Inertes.

${ }^{48}$ Encontra-se em tramitação na Câmara dos Deputados o Projeto de Lei (PL) n. 203, de 1991, do Senado Federal, que "dispõe sobre o acondicionamento, a coleta, o tratamento, o transporte e a destinação final dos resíduos de serviços de saúde". O processo foi objeto de análise em 2006, tendo sido aprovado juntamente com seus apensos na forma de um substituto. Após a aprovação, outras proposições foram apensadas ao PL 203/1991, incluindo o PL 1.991/2007, do Poder Executivo, que "institui a Política Nacional de Resíduos Sólidos e dá outras providências". Recentemente um Grupo de Trabalho produziu novo substituto a ser votado no plenário da Câmara e que, caso aprovado, estabelecerá uma padronização nos conceitos atinentes aos diferentes tipos de resíduos. Convém descrever os pontos do projeto de lei que influenciarão o saneamento. Em primeiro lugar, a proposta traz uma classificação dos resíduos quanto àq sua origem e periculosidade: "Art. 13. Para os efeitos desta Lei, os resíduos sólidos têm a seguinte classificação: I quanto à origem: a) resíduos domiciliares: os originários de atividades domésticas em residências urbanas; b) resíduos de limpeza urbana: os originários da varrição, limpeza de logradouros e vias públicas e outros serviços de limpeza urbana; c) resíduos sólidos urbanos: os resíduos englobados nas alíneas 'a' e 'b'; c) resíduos de estabelecimentos comerciais e prestadores de serviços: os geradores nessas atividades, executados os referidos nas alíneas 'b', 'e', 'g', 'h' e 'j'; d) resíduos dos serviços de saneamento básico: os gerados nessas atividades, excetuados os referidos na alínea 'c'; e) resíduos industriais: os gerados nos 
Verifica-se, por outro lado, no ordenamento brasileiro, a existência de normas infralegais federais e leis e normas estaduais e municipais que indicam ou determinam as condições mínimas para o manejo dos diferentes tipos de resíduos e os responsáveis pela sua gestão.

Tal profusão de normas, a qual impede uma descrição exaustiva do regime de cada um dos resíduos descritos, deriva do sistema de repartição de competências adotado na Constituição no que toca à matéria ambiental. O meio ambiente e o controle de poluição, áreas temáticas em que se insere a delimitação da responsabilidade pelos resíduos, são objeto de competência legislativa concorrente e de competência material comum dos entes federados. ${ }^{49}$

Cada categoria de resíduos está subordinada a exigências de gestão compatíveis com suas características físico-químicas, vale dizer, está submetida a

processos produtivos e instalações industriais; f) resíduos de serviços de saúde: os gerados nos serviços de saúde, conforme definido em regulamento ou em normas estabelecidas pelos órgãos do Sisnama e do SNVS; g) resíduos de construção civil: os gerados nas construções, reformas, reparos e demolições de obras de construção civil, incluídos os resultantes da preparação e escavação de terrenos para obras civis; h) resíduos agrosilvopastoris: os gerados nas atividades agropecuárias e silviculturais, incluídos a insumos utilizados nessas atividades; i) resíduos de serviços de transportes: os originários de portos, aeroportos, terminais alfandegáros, rodoviários e ferroviários, e passagens de fronteira; j) resíduos de mineração: os gerados na atividade de pesquisa, extração ou beneficiamento de minério. II - quanto à periculosidade: a) resíduos perigosos: resíduos que, em razão de suas características de inflamabilidade, corrosividade, reatividade, toxicidade, patogenicidade, carcinogenicidade, teratogenicidade e mutagenicidade, apresentam significativo risco à saúde pública ou à qualidade ambiental, de acordo com lei, regulamento ou norma técnica; d) resíduos não perigosos: resíduos não enquadrados na alínea 'a'." Diz o parágrafo único do art. 13 que o poder público municipal pode equipar resíduos de saneamento básico a resíduos domiciliares desde que não perigosos: "respeitado o disposto no art. 20, os resíduos referidos na línea 'd' do inciso I do caput, se caracterizados como não perigosos, podem, em razão de sua natureza, composição ou volume, ser equiparados aos resíduos domiciliares pelo Poder Público municipal." Estabelecida a classificação, a proposta define os responsáveis pela gestão de cada tipo de resíduo, comprovando a ideia de que nem todo sistema de tratamento de resíduos consiste em serviços públicos, sendo antes atividades privadas submetidas a regulação pública: "Art. 20. Estão sujeitos à elaboração de plano de gerenciamento de resíduos sólidos: I - os geradores de resíduos sólidos previstos nas alíneas 'e', 'f' 'g' e 'k' do inciso I do art.13; II - os operadores de resíduos; III - os estabelecimentos comerciais e de prestação de serviços que: a) gerem resíduos perigosos; b) gerem resíduos que, mesmo caracterizados como não perigosos, por sua natureza, composição ou volume, não sejam equiparados aos resíduos domiciliares pelo Poder Público municipal; IV - as empresas de construção civil, nos termos do regulamento ou de normas estabelecidas pelos órgãos do Sisnama; V - os responsáveis pelos terminais e outras instalações referidas na alínea 'I' do inciso I do art. 13 e, nos termos do regulamento ou de normas estabelecidas pelos órgãos do Sisnama e, se couber, do SNVS, as empresas de transporte; VI - os responsáveis por atividades agrosilvopastoris, se exigido pelo órgão competente do Sisnama, do SNVS ou do Suasa. [...]”.

${ }^{49}$ Nos termos do art. 24 da Constituição da República: “Art. 24. Compete à União, aos Estados e ao Distrito Federal legislar concorrentemente sobre: [...] VI - florestas, caça, pesca, fauna, conservação da natureza, defesa do solo e dos recursos naturais, proteção do meio ambiente e controle da poluição". Lembre-se também da existência de competência legislativa suplementar do Município descrita no inciso II do art. 30 da Constituição. O art. 23 da Carta de 1988 determina: “Art. 23. É competência comum da União, dos Estados, do Distrito Federal e dos Municípios: [...] VI - proteger o meio ambiente e combater a poluição em qualquer de suas formas". 
requisitos de tratamento e disposição final adequados e adaptados ao seu impacto no meio ambiente, bem como se encontra sob a esfera de responsabilidade de seus respectivos geradores.

No caso dos resíduos urbanos - lixo doméstico e lixo da limpeza urbana -, os geradores têm cessada sua responsabilidade com a disponibilização adequada dos resíduos para a coleta. Após a coleta, cabe ao Poder Público zelar pelo seu tratamento e disposição final.

Diante dos múltiplos tipos de resíduos existentes e da terminologia adotada pela Lei Nacional de Saneamento (ainda que sujeita a imprecisões em virtude da ausência de uma categorização legal inequívoca a respeito dos resíduos), bem como do disposto expressamente em seu art. $5^{\circ}$, constata-se que a norma não abarcou a integridade das ações destinadas ao manejo de resíduos, centrando seus ditames no lixo doméstico e no oriundo da varrição e limpeza pública, espécies integrantes dos resíduos sólidos urbanos.

A opção realizada pela lei apresenta consequências relevantes: retira do espectro do serviço público as atividades de gestão de resíduos de responsabilidade exclusiva do gerador, tais como resíduos oriundos de atividade industrial, resíduos oriundos de atividades de saúde, resíduos da construção civil, etc.

Fora da designação do serviço público, essas atividades dispensam a concessão prévia da Administração para seu desempenho. São, em essência, atividades privadas submetidas a uma intensa regulação e que, se desempenhadas em desacordo com os parâmetros normativos, podem acarretar punições aos responsáveis.

$\mathrm{O}$ art. $6^{\circ}$ da Lei n. 11.445/2007 designa uma série de tipos de resíduo que não integram, a priori, os resíduos urbanos, a não ser que decisão do Poder Público assim determine. São eles: "o lixo originário de atividades comerciais, industriais e de serviços cuja responsabilidade pelo manejo não seja atribuída ao gerador pode, por decisão do poder público, ser considerado resíduo sólido urbano.”.

Vê-se que o dispositivo confere certa margem de liberdade a que o Poder Público inclua nos âmbito dos serviços públicos de saneamento outros tipos de resíduos.

A utilização no art. $6^{\circ}$ da expressão "poder público" e não "titular" dos serviços, provavelmente, indica o cuidado do legislador em não restringir a apenas um ente federado a prerrogativa para a inclusão de novos tipos de resíduos nos serviços de 
saneamento, tendo em vista o regime de competência concorrente sobre meio ambiente acima citado.

Seria possível, assim, cogitar de norma federal conferindo maior abrangência à noção de resíduos sólidos urbanos, ou mesmo, nas lacunas que a normatização federal proporcionar, um detalhamento promovido por normas estaduais e municipais que provocassem o aumento do escopo dos serviços de saneamento nos termos autorizados pelo próprio art. $6^{\circ}$ da Lei Federal n. 11.445/2007.

$\mathrm{O}$ art. $7^{\circ}$ da Lei Nacional de Saneamento detalha os serviços de manejo de resíduos. A divisão estabelecida pelo dispositivo configura um confiável roteiro para um aprofundamento nas características de cada atividade.

- Coleta, transbordo e transporte dos resíduos - A coleta é o recolhimento dos resíduos para sua disposição final. Nos termos da NBR n. 12.980, de 1993, a coleta deve se adaptar aos diferentes origens dos resíduos, classificando-se em domiciliar; especial (destinada à remoção e transporte de resíduos de características próprias com origem, peso e volumes especiais), hospitalar externa, de resíduos com riscos para saúde (portos, aeroportos e terminais), de resíduos de serviços de saúde e coleta de resíduos de feiras, praias e calçadões.

Entre a coleta e a destinação final é possível a instalação de áreas de transbordo, locais onde o veículo coletor transfere os resíduos para outros veículos de maior porte - caminhões maiores, barcas, trem, etc. (ARAÚJO, 2008, p. 93). As áreas de transbordo oferecem escala aos serviços, prestando-se como posto intermediário para o transporte de resíduos em longas distâncias e permitindo, conforme o caso, a compactação do material para seu melhor acondicionamento.

- Triagem para fins de reúso ou reciclagem, de tratamento, inclusive por compostagem, e de disposição final dos resíduos - A coleta e o transporte de resíduos podem ser associados ao processo de triagem, nos quais os resíduos são segregados em usina apropriada. A separação tornará possível o reúso de materiais (garrafas higienizadas, resíduos da construção civil, etc.), sua reciclagem e tratamento.

O tratamento é caracterizado como o conjunto de "procedimentos destinados a reduzir a quantidade ou o potencial poluidor dos resíduos sólidos, seja impedindo o 
descarte do lixo em ambiente ou local inadequado, seja transformando em material inerte ou biologicamente estável”. (ARAÚJO, 2008, p. 98)

Integra o conceito de tratamento o processamento dos resíduos em incineradores e usinas de compostagem, as quais promovem a "transformação orgânica dos resíduos sólidos, que, depois de processada biologicamente, se transforma em novo produto" passível de aplicação em outros usos como no caso de fertilizantes (ARAÚJO, 2008, p. 99). Os resíduos não passíveis de reúso ou reciclagem são destinados à disposição final.

No que toca a resíduos sólidos urbanos, a técnica de disposição final mais comum é construção de um aterro sanitário, encarado como uma obra de engenharia projetada sob critérios técnicos para disposição do lixo sem danos à saúde pública e ao meio ambiente.

A correta construção de aterros deve observar cuidados especiais que envolvem a proteção de águas superficiais e subterrâneas contra contaminações; compactação de resíduos em células especiais que permitam simultaneamente o tráfego de veículos transportadores; a cobertura periódica das camadas de resíduos, o controle dos líquidos e gases produzidos pelo aterro e o isolamento da área evitando incômodos à população. (ARAÚJO, 2008, p. 99)

- Varrição, capina e poda de árvores em vias e logradouros públicos e outros eventuais serviços pertinentes à limpeza pública urbana - A atividade de limpeza urbana, executada por ações de varrição, capina e pode de árvores, aparentemente simples, envolve uma dispendiosa alocação de recursos humanos e preparação logística. (ARAÚJO, 2008, p. 120)

A execução da limpeza implica a criação de um plano de varrição que contemple os setores da cidade e as respectivas frequências de varrição. Do mesmo modo, a capina e a poda de árvores exigem a aquisição de equipamentos apropriados e a formulação de um plano de trabalho eficiente. Integram ainda os serviços de limpeza urbana as atividades de: raspagem, roçagem, limpeza de ralos, limpeza de feiras, praias, desobstrução de ramais, galerias, desinfestação e desinfecções, pintura de meio-fios e lavagem de logradouros públicos. (ARAÚJO, 2008, p. 121) 
Verifica-se que a operação de resíduos difere significativamente do abastecimento de água e coleta de esgoto. A rede de resíduos não tem utilização tão específica e por exigir recursos de menor monta para instalação convive com um número menor de barreiras à entrada e à saída, todas essas características mais próximas de um serviço comercial convencional (TUROLLA, 2006, p. 20). Em outras palavras, a configuração do monopólio natural é mais improvável na limpeza urbana e no manejo de resíduos sólidos.

Acrescente-se que, à semelhança do que ocorre com algumas das atividades dos serviços de água e esgoto, a limpeza urbana pode ser fracionada em atividades essencialmente locais, como a coleta de resíduos nos domicílios e varrição e limpeza de logradouros públicos, e outras em que uma abrangência regional pode ter influência significativa.

Nesse último caso, sistemas de transbordo e usinas de reciclagem, por demandarem um volume significativo de resíduos para seu funcionamento, poderiam ser organizados conjuntamente por Municípios interessados. Imperativos ambientais e mesmo geográficos (inexistência de áreas de aterro em determinados Municípios) podem redundar, também, na necessidade de atuação concatenada dos entes políticos.

Mais uma vez a possibilidade de desagregação de atividades se faz presente como instrumento para a organização dos serviços, possibilitando a convivência de diversos operadores, bem como a inserção de alguns dos aspectos ou atividades integrantes dos serviços em um sistema de gestão compartilhada.

\subsubsection{O manejo de águas pluviais}

$\mathrm{Na}$ Europa, o crescimento das cidades provocado pelo desenvolvimento industrial e pela migração da força de trabalho potencializou os problemas sanitários, mas abriu espaço, simultaneamente, para o aparecimento de novas concepções de gestão urbana que visavam contornar os problemas então verificados (concepções higienistas que afetaram cidades em todo o mundo e também no Brasil). 
As grandes cidades do século XIX, fruto da revolução industrial, criaram novas culturas organizacionais (habitacional, produtiva, etc.) que não haviam atingido ainda a completa maturidade a respeito de seu ordenamento territorial. (MARTINS, 2006, p. 33)

As primeiras manifestações do manejo de águas pluviais no ambiente urbano, ocorridas no contexto da revolução sanitária do século XIX, tinham como princípio fundamental a imprescindibilidade da fluidez da água, que deveria circular rapidamente, pois sua estagnação era sinônimo de condições insalubres para o homem. (MARTINS, 2006, p. 33)

A concepção que valorizava a condutividade da hidráulica (seu escoamento o mais rápido possível,) como regra de outro da drenagem predominou durante o que pode ser denominado de primeira fase do saneamento pluvial, em que a eliminação de águas ocorria por meio de dutos subterrâneos.

Nesse período, foram elaboradas e estabelecidas as relações iniciais entre a precipitação pluvial e as estruturas para seu escoamento. Em uma segunda etapa, buscou-se a racionalização dos cálculos hidrológicos, sua normatização e padronização voltadas para a melhor concepção das estruturas hidráulicas correspondentes. Ainda preponderava a noção de elevada condutividade hidráulica como principal meio para solução dos problemas de drenagem.

A terceira etapa do desenvolvimento da drenagem se inicia nas décadas de 1960 e 1970 estendendo-se até os dias atuais, marcada pela conjunção do planejamento integrado dos diversos setores do saneamento com preocupações ambientais e com a gestão integrada do ciclo hidrológico urbano. Nesse momento, o escoamento da água deixa de ser a única opção da drenagem, abrindo-se espaço para, por exemplo, obras de retenção e amortecimento, reservatórios e lagoas de detenção e pavimentos permeáveis (que permitem que a água seja infiltrada no solo). (MARTINS, 2006, p. 36-37)

Um breve exame da estrutura das cidades demonstra a atração que as águas exercem sobre as agregações humanas, fundamentalmente por razões de subsistência. Essa proximidade contribuiu para o problema do controle das águas pluviais, causadoras de enchentes e prejuízos de elevada monta para as cidades. 
De fato, a sobrecarga do sistema de drenagem pluvial ocorre, em geral, pela ocupação das áreas de risco pela população durante os períodos secos e pela urbanização do solo e a canalização dos rios urbanos. (MONTENEGRO; TUCCI, 2005, p. 9) 50 $^{50}$

A urbanização gera, como se sabe, uma diversidade de impactos que influenciam o funcionamento da drenagem:

(i) aumento das vazões máximas e da sua frequência em decorrência do escoamento mais rápido das águas e da redução da permeabilidade do solo (em razão de telhados, ruas, pátios e calçadas);

(ii) aumento da erosão, da produção de sedimentos e de resíduos; ${ }^{51}$

(iii) redução da qualidade da água superficial e subterrânea em razão do carreamento de material sólido, lavagem das ruas, ligações clandestinas de esgoto cloacal e pluvial e contaminação de aquíferos; ${ }^{52}$

(iv) urbanização desorganizada, que acarreta: obstrução do escoamento por pontes e taludes de estradas; redução de seção do escoamento por aterros de pontes e para outras construções; deposição e obstrução de rios, canais e condutos por resíduos e sedimentos e projetos e obras de drenagem inadequados. (MONTENEGRO; TUCCI, 2005, p. 12)

${ }^{50}$ Conforme informa Tucci (2006, p. 40), “os rios normalmente drenam nas suas cabeceiras, áreas com grande declividade, produzindo escoamento de alta velocidade. Quando a declividade diminui, a capacidade de escoamento naturalmente diminui e ocorrem alagamentos no leito maior. A variação de nível durante uma enchente pode ser de vários metros em poucas horas. Quando o relevo é acidentado, as áreas mais propícias à ocupação são as planas e mais baixas, justamente aquelas que apresentam alto de risco de inundação e que estão mais ocupadas pela população. A várzea de inundação de um rio cresce significativamente nos seus cursos médio e baixo, onde a declividade se reduz e aumenta a incidência de áreas planas".

51 A urbanização apresenta estágios claros de evolução na produção de resíduos e sedimentos que são incorporados aos cursos de água:

(i) estágio de pré-desenvolvimento: na bacia hidrográfica, o clico hidrológico natural produz sedimentos transportados para o rio;

(ii) estágio inicial de desenvolvimento urbano: a retirada da cobertura vegetal e a terra movimentada em decorrência de obras aumenta o transporte de sedimentos para os rios. Nesse fase, os sedimentos predominam sobre o lixo.

(iii) estágio intermediário: para os rios são transportados sedimentos de construções ainda realizadas e lixo decorrente da maior população estabelecida;

(iv) estágio de área desenvolvida: as superfícies urbanas estão consolidadas, resultando numa produção residual de sedimentos resultante das áreas não-impermeabilizadas, mas a produção de lixo urbano atinge seu limite, com a densificação urbana. (MONTENEGRO e TUCCI, 2005, p.13)

52 Conforme informam Orsini e Tucci (2005, p. 255), "a qualidade da água do pluvial não é melhor que a do efluente de um tratamento secundário. [...] Os poluentes que ocorrem na área urbana variam muito, desde compostos orgânicos a metais altamente tóxicos." São poluentes comuns no sistema pluvial: inseticidas, fertilizantes, chumbo, fuligem resultante das emissões de gases dos veículos, das indústrias e da queima de resíduos, sedimentos em geral, nutrientes, substâncias que consomem oxigênio, metais pesados, hidrocarbonetos de petróleo, bactérias e vírus patogênicos. Naturalmente, a água pluvial poluída atinge e contamina os rios. 
Acrescente-se a isso a ocupação de áreas de risco próximas a regiões de várzea pela população, que contribuem para a deposição de resíduos nos canais de escoamento e, obviamente, aproximam as moradias das faixas de enchente. Tais circunstâncias contribuem, inevitavelmente, para a ocorrência de inundações (inundação ribeirinha e inundação decorrente da urbanização ou da drenagem urbana). ${ }^{53}$

$\mathrm{Na}$ definição legal, a drenagem e o manejo das águas pluviais urbanas constituem o "conjunto de atividades, infra-estruturas e instalações operacionais de drenagem urbana de águas pluviais, de transporte, detenção ou retenção para o amortecimento de vazões de cheias, tratamento e disposição final das águas pluviais drenadas nas áreas urbanas”. (Art. 30, “d”, da LNS)

Da perspectiva econômica, as redes de drenagem apresentam características semelhantes às de esgoto. Demandam elevados investimentos iniciais e os ativos criados apresentam especificidades que os inabilitam para outras funções.

Estruturalmente, os canais para esgotamento sanitário e para águas pluviais podem ser combinados (cloacal e pluvial num mesmo conduto) ou separados (rede pluvial e sanitária separadas). No Brasil, a maioria das redes é distinta, existindo áreas antigas de cidades onde os sistemas são combinados e Municípios com baixa capacidade financeira para ampliação da rede de cloacal que têm permitido o uso da rede pluvial para o transporte do esgoto, solução questionável já que o esgoto não é tratado e inviabiliza soluções de controle quantitativo e qualitativo das águas pluviais. (ORSINI; TUCCI, 2005, p. 254)

As redes pluviais podem ser divididas em sistemas de microdrenagem (também chamada de rede primária) e macrodrenagem, as primeiras prestantes a captar a água precipitada em lotes e vias e transportá-la para os canais de macrodrenagem. Este último

\footnotetext{
${ }^{53}$ Segundo Tucci e Orsini (2005, p. 244), “o manejo das águas pluviais e o controle dos impactos sobre a sociedade devem ser entendidos em dois ambientes distintos (capítulo 1): a bacia hidrográfica de médio e grande porte (> $500 \mathrm{~km} 2$ ), na qual predomina a ocupação rural, com inundações naturais quando o rio ocupa seu leito maior denominado aqui de Inundações ribeirinhas; e na bacia pequena, na qual predomina a urbanização do solo (geralmente variando de 2 a $100 \mathrm{~km} 2$ ), e onde prevalece o aumento da inundação por conta dos efeitos de impermeabilização do solo e da aceleração do escoamento decorrente de condutos e canais, denominado aqui de drenagem urbana. Em algumas cidades ou regiões metropolitanas, esses dois cenários podem ocorrer na mesma bacia."
} 
sistema, constituído por canais naturais ou construídos, direciona a água de uma bacia de drenagem para locais a jusante: rios, córregos, represas, etc. (MARTINS, 2006, p. 45) ${ }^{54}$

O controle da inundação pode ser realizado por meio de medidas estruturais e não-estruturais. São estruturais as obras de intervenção no sistema fluvial, na bacia (medidas extensivas) ou no rio (medidas intensivas). ${ }^{55}$ (TUCCI, 2006, p. 48)

As medidas não-estruturais, por sua vez, têm caráter preventivo e visam a uma melhor convivência da população com as enchentes, são elas: o alerta de inundação, o zoneamento das áreas de risco, o seguro contra inundações e as medidas de proteção individual (flood proofing). (TUCCI, 2006, p. 48)

A figura do zoneamento como medida preventiva demonstra a proximidade do tema da drenagem urbana com os assuntos locais do Município.

É possível afirmar que as regras municipais sobre o zoneamento urbano, a respeito do uso e a ocupação do solo e da produção de edificações (que disciplinarão a percentual permitido de impermeabilização do solo, a construção de sistemas de microdrenagem no interior do lote urbano e sua conexão com as redes exteriores de drenagem, etc.) integram em parte o regime jurídico da drenagem e compõem o quadro maior que deve ser analisado para a compreensão da matéria. Com efeito, os munícipes estão submetidos a limites para instalação de seus prédios nas áreas das cidades.

Do ponto de vista de suas características físicas e das regras que disciplinam a interação dos munícipes com a drenagem, é inegável que os sistemas pluviais apresentam um caráter local, especialmente as estruturas de microdrenagem, o que enfraqueceria as razões para sua gestão compartilhada com outros entes federados.

Entretanto, situações haverá em que a gestão compartilhada será aconselhável. Uma boa gestão das águas pluviais impacta, como demonstrado no início deste capítulo, a qualidade das águas dos rios urbanos, muitos dos quais perpassam o território de Municípios contíguos.

\footnotetext{
${ }^{54}$ Integram a microdenagem: galeria, poço de visita, trecho, bocas-de-lobo, tubos de ligações, meios-fios, sarjetas, sarjetões, condutos forçados e estações de bombeamento. Já a macrodrenagem é constituída por canais naturais alterados ou canais artificiais e grandes galerias. (MARTINS, 2006, p. 46)

${ }^{55}$ As medidas extensivas modificam as relações entre precipitação e vazão: a alteração da cobertura vegetal do solo, que reduz e retarda os picos de enchente e controla a erosão da bacia. As medidas intensivas "são aquelas que agem no rio e podem ser de três tipos (SIMONS et al., 1977): a) aceleram o escoamento: construção de diques e polders, aumento da capacidade de descarga dos rios (canais) e corte de meandros; b) retardam o escoamento: reservatórios e bacias de amortecimento; c) facilitam o desvio do escoamento: são obras como canais de desvios". (TUCCI, 2006, p. 50)
} 
A sobrecarga de vazão de água à jusante realizada pelo sistema de drenagem de mal concebido por um Município pode afetar o território municipal a contíguo e conurbado, gerando enchentes e outros problemas, já que canais naturais de drenagem (rios e córregos) costumeiramente são compartilhados pelas unidades políticas.

Estações de tratamento de águas pluviais podem ser criadas e utilizadas de forma compartilhada pelos Municípios, possibilitando o atendimento de toda ou parte de uma bacia hidrográfica.

Como se vê, sobretudo em regiões metropolitanas, sistemas de drenagem de um Município interferem nas cidades limítrofes, impelindo o relacionamento dos entes federados para o bom desenvolvimento do saneamento pluvial por meios de mecanismos integrados de macrodrenagem. 


\section{OS FUNDAMENTOS DA GESTÃO COMPARTILHADA}

\subsection{DELIMITAÇÃO DA GESTÃO COMPARTILHADA}

Pressuposto para o desenvolvimento da dissertação será o assentamento das fronteiras da gestão compartilhada dos serviços de saneamento.

A gestão compartilhada do saneamento consiste em conceito funcional ou instrumental, aplicado aqui para proporcionar o estudo sistematizado dos diferentes institutos e normas relacionados à gestão de serviços públicos.

Representa uma circunstância especial na qual atores públicos e privados, normas constitucionais, legais e regulamentares, bem como condicionantes geográficos, econômicos e ambientais, congregam-se de forma a justificar uma prestação conjunta dos serviços de saneamento por dois ou mais entes federados.

Essa prestação conjunta exigirá peculiar conformação organizacional para colocação em prática dos serviços de saneamento, bem como exigirá a compatibilização com esse contexto dos diferentes instrumentos jurídicos tradicionalmente aplicados na prestação de serviços públicos.

A expressão "gestão compartilhada" foi propositadamente cunhada por diferenciar-se da terminologia "gestão associada" de serviços públicos (prevista no art. 241 da Constituição da República), aqui compreendida como manifestação específica da própria gestão compartilhada.

Verifica-se, nesse ponto, que a expressão "gestão compartilhada" tem um sentido abrangente, que permite aglutinar de modo satisfatório as situações em que ocorrerá a prestação coordenada dos serviços entre dois ou mais entes federados.

Desse modo, a nota característica do conceito proposto é a conjugação de esforços de dois ou mais membros da federação, circunstância que, inegavelmente, o aproxima do imenso temário representado pela evolução do Estado Federal e das complexas relações que abarca.

Assim, a gestão compartilhada abrangerá a gestão associada dos serviços públicos de que trata o art. 241 da Constituição da República e o desenvolvimento do 
saneamento nas regiões metropolitanas, aglomerações urbanas e microrregiões, sem prejuízo das manifestações históricas da prestação regionalizada, por meio da relação entre as empresas estaduais de saneamento e os Municípios contratantes. Abarcará tanto a conjugação de esforços entre Municípios, quanto entre estes e Estados e União.

Conforme se depreende da delimitação ora realizada, pode-se antecipar, sem receios, que os fundamentos da gestão compartilhada são simultaneamente jurídicos e econômico-gerenciais.

No primeiro caso, as relações federais disciplinadas pelo sistema constitucional brasileiro e encaradas sob o prisma da cooperação entre entes políticos figuram como tarefa primeira de análise. Importará compreender minimamente a dinâmica do Estado Federal no Brasil e de seus efeitos na gestão compartilhada.

As razões econômico-gerenciais para a utilização da gestão compartilhada são também pontos relevantes de estudo, já que apresentam inúmeros condicionantes concretos para o tema proposto. Todos esses fatores serão objeto de consideração pormenorizada logo adiante.

\subsection{FUNDAMENTOS JURÍDICO-CONSTITUCIONAIS: A DELIMITAÇÃO DA COOPERAÇÃO FEDERAL}

Desnecessário dizer que as balizas fundamentais da gestão compartilhada se identificam com aquelas que conduzem o funcionamento e a evolução do Estado Federal. Com efeito, a gestão compartilhada somente faz sentido como figura jurídica inserida em um contexto federativo, já que pressupõe o compartilhamento de competências constitucionais.

Desde sua primeira manifestação juridicamente paupável e bem delineada na experiência norte-americana, o Estado Federal colocou-se como uma criativa e ao mesmo tempo complexa forma de organização do poder político e das funções administrativas de determinado povo e território. ${ }^{56}$

${ }^{56}$ A ideia de distribuição de responsabilidades entre as unidades federadas em prol da manutenção da unidade na diversidade encontra-se presente desde as primeiras formulações do federalismo. Nas palavras de Hamilton (1959, p. 94), "se as circunstâncias de nosso país são tais que requerem um governo composto 
Horta (1999, p. 14) realiza percuciente enumeração das características fundamentais que podem se encontradas na maior parte dos Estados federais:

(i) composição plural dos entes constitutivos;

(ii) indissolubilidade do vínculo federativo;

(iii) soberania da União;

(iv) autonomia do Estado Federado ou Estado-Membro;

(v) repartição de competências;

(vi) intervenção federal;

(vii) organização bicameral do Poder Legislativo da União;

(viii) repartição tributária;

(ix) dualidade do Poder Judiciário e a existência de um Supremo Tribunal, para exercer a função de Guarda da Constituição.

Outra característica comum aos modelos federais, pelo menos em uma perspectiva estritamente conceitual, é a de apresentar como sustentáculo, desde seus primórdios, as noções de união, coordenação cooperação e esforço mútuo. ${ }^{57}$

Os pontos de identidade ressaltados, bem como a propensão congênita do federalismo à cooperação, não escondem as vicissitudes históricas vividas pelas diferentes experiências federativas.

Não existem Estados Federados idênticos em sua estrutura, divisão de poder e repartição de competências. Dispensa surpresas, portanto, a dificuldade em se atingir um conceito universal de federalismo que aglutine todas as hipóteses fáticas existentes.

e confederado ao invés de um só e simples, o ponto essencial que permanece por acertar consiste em distinguir, tão completamente como seja possível, os assuntos que corresponderão às diferentes jurisdições ou departamentos do poder, adjudicando a cada um a mais ampla autoridade para levar a cabo os assuntos que fiquem a seu cuidado. Constituir-se-á a União em custódia da segurança comum? Para realizar estes fins, são necessários exércitos, frotas e dinheiro? O governo da União deve estar facultado para expedir todas as leis e para fazer todos os regulamentos que se relacionem com eles. O mesmo deve ocorrer no caso do comércio, e de todas as demais matérias ao alcance de sua jurisdição. A administração da justiça entre os cidadãos do mesmo Estado é um ramo próprio dos governos locais? Pois então estes devem assumir todas as faculdades que tenham conexão com este assunto e com todos os que sejam determinados por seu particular conhecimento e direção. O não conferir, em cada caso, o grau de poder proporcionado ao fim que se persegue, significaria violar as regras mais evidentes da prudência e a conveniência, e confiar desprevenidamente os grandes interesses da nação em mãos que se inabilitam para manejá-los com vigor e êxito".

57 Conforme nos informa Horta (1999, p. 19), "a relação entre federalismo e cooperação, de modo geral, sugere, na etimologia da palavra federal, que deriva de foedus: pacto, ajuste, convenção, tratado e entra na composição dos laços de amizade, foedus amicitae. A associação das partes componentes está na origem do Estado Federal [...]". 
Já o grau de coordenação e cooperação verificável entre os entes integrantes dos Estados que adotam o modelo federativo tem variado em correspondência às alterações sofridas pelo papel do Poder Público como agente fomentador do desenvolvimento social e pela evolução da cultura política dos países em questão.

Nesse contexto, o modelo federativo brasileiro, e em seu bojo a prestação dos serviços de saneamento, encontra-se em processo de transformação e adaptação constantes. Nos dizeres de Justen Filho (2005a, p. 201),

\begin{abstract}
há um outro dado a ser considerado. $\mathrm{O}$ modelo federativo brasileiro ainda não pode ser reputado como definitivo - diversamente do que ocorre com diversos outros Estados federados existentes no mundo ocidental.

Assim se passa em virtude do que se poderia denominar de 'amadurecimento incompleto' do processo político brasileiro. Embora a Constituição de 1988 tenha representado um passo decisivo na modelagem da organização estatal brasileira, não se produziu uma organização política dotada de estabilidade definitiva. Somente a estabilidade democrática é que produzirá a estabilidade institucional.
\end{abstract}

A ideia de cooperação federativa não se exaure em digressões puramente institucionais ou jurídico-formais de índole constitucional. As interferências políticas, sociais e econômicas, intrinsecamente ligadas à questão, operam como fatores de atraso ou aceleração da integração da atividade administrativa a cargo de cada ente, sobretudo no que toca ao exercício de competências materiais associadas à prestação de serviços públicos.

Embora tenha ocorrido de forma casuística e pragmática, a evolução do federalismo norte-americano é esclarecedora a respeito das transformações do sistema constitucional de cooperação em diferentes épocas e países.

Durante o governo de F. K. Roosevelt, marcado pelas concepções keynesianas de intervenção do Poder Público no domínio econômico e social e momento em que a concepção de Estado sofria profundas mudanças (Welfare State), houve, impulsionada pelas circunstâncias então presentes (New Deal), a superação do dual federalism (federalismo dual) que contrapunha o ordenamento da União e dos Estados, evoluindo para o "novo federalismo", sob o qual se intensificou a ajuda federal aos Estados por meio de programas e convênios. (HORTA, 1999)

Considerando-se a relação intrínseca entre o tema deste trabalho e a conformação concreta das relações federativas, convém, desde já, lançar as bases de um 
conceito de cooperação federal a fim de subsidiar as impressões colhidas a respeito da dinâmica do Estado Federal no Brasil e seus efeitos na gestão compartilhada do saneamento básico, objetivo principal desse tópico.

Como dito, a noção de cooperação é ínsita à Federação, sendo até certo ponto redundante a menção a um federalismo cooperativo.

Levada tal premissa à sua consequência extrema, a cooperação federal seria, na realidade, um dever a ser observado pelos integrantes do Estado Composto, independentemente da previsão constitucional de práticas obrigatórias de cooperação. Um dever implícito e inafastável, a ser seguido por todos os entes político-administrativos. Tudo isso por ser a cooperação condição para a manutenção da integridade federal.

A compreensão da cooperação federal como um dever absoluto não dá conta, obviamente, das práticas federativas assentadas na livre vontade das entidades políticas.

De outro lado, a decisão de cooperar fundada apenas na livre escolha dos entes federados gera dificuldades próprias. Sob essa perspectiva, dificilmente poderia a cooperação ser imposta judicialmente ou impingida por meios de instrumentos como a intervenção federal. (SILVEIRA, 2007, p. 446)

Silveira (2007, p. 446) bem coloca que o grande desafio doutrinário no que respeita à cooperação reside na incompatibilidade, primeiramente, entre o caráter voluntário do ato de cooperar e sua qualificação como dever jurídico próprio de todo e qualquer integrante do Estado Composto. Informa a autora citada que a doutrina jurídica estrangeira tem se debruçado sobre a questão.

$\mathrm{Na}$ Espanha encontra-se a tentativa de sistematizar a diferentes formas de relacionamento intergovernamental (frise-se que a Espanha não é um Estado Federal) com base no tipo de competência partilhada e na relação entre as entidades envolvidas. Uma verdadeira tipologia de práticas, construída com fundamento nas características primárias de cada caso ou situação. ${ }^{58}$

A colaboração corresponderia à contribuição ou assistência em competências que pertencem a outro ente; a cooperação dar-se-ia de forma voluntária e entre entidades em situação de igualdade jurídica; já a coordenação corresponderia às situações em que um dos entes envolvidos (o coordenador) possui alguma forma de preponderância ou superioridade sobre os coordenados. (SILVEIRA, 2007, p. 447)

\footnotetext{
${ }^{58}$ Para maiores informações sobre a dinâmica das relações intergovernamentais na Espanha recomenda-se Alles (2004) e Rovira (1985).
} 
Esse desenho classificatório é de difícil aplicação no Brasil em que, a rigor, a igualdade jurídica entre as unidades federadas é uma premissa constitucional, ainda que seja possível reconhecer situações de preponderância inicial de determinados entes sobre outros, como no caso das regiões metropolitanas em que a lei complementar estadual impõe o contexto metropolitano aos Municípios ou no caso das regiões administrativas (art. 43 da Constituição, adiante mencionado) em que o controle da unidade regional criada é da União, que ditará os rumos da figura.

Bercovici e Siqueira Neto (2008, p. 52-53) oferecem uma distinção entre coordenação e cooperação lastreada no grau de integração e sinergia presentes nas relações interfederativas. A coordenação corresponde, segundo os autores, à atribuição e exercício conjunto de competências em que a vontade das partes é igual e os entes podem sempre atuar de maneira isolada ou autônoma. Exemplificam com as competências legislativas concorrentes: a função de cada ente é a mesma, a legislativa, mas com escopo e intensidades distintas. As partes tomam decisões autônomas, desde que observadas suas respectivas áreas de atuação, e, no caso dos demais entes federados, as normas gerais editadas pela União.

$\mathrm{Na}$ cooperação, nenhum ente político pode atuar isoladamente, pois todos exercem suas competências em conjunto com os demais. As competências comuns descritas no art. 23 da atual Constituição simbolizam o espaço fundamental para atuação cooperativa. No exercício dessas competências não há distinção de importância ou preponderância entre os membros da federação. Nesse caso, a cooperação pressupõe a interdependência das matérias e programas de interesse comum, a viabilizar um mecanismo unitário de decisão e organização que poderá resultar na execução conjunta ou mesmo separada de políticas e serviços públicos. (BERCOVICI; SIQUEIRA NETO, 2008, p. 54-55)

A conceituação oferecida por Silveira (2007) complementa as linhas gerais ora traçadas, dando conta de outras gradações presentes no conceito almejado de cooperação, uma vez que se fundamenta no caráter obrigatório ou voluntário presente em cada tipo de experiência cooperativa.

Segundo a autora, a cooperação apresenta uma dimensão passiva, podendo incorporar, eventualmente, uma dimensão ativa. A dimensão passiva se identifica com a obrigação de cooperar existente em toda e qualquer dinâmica federal. Traveste-se nos 
deveres de moderação recíproca na atuação das unidades políticas, abstenção do exercício de poderes formalmente acometidos quando tal eventualmente comprometa o sucesso da totalidade sistêmica federal e proibição da omissão de auxílio (SILVEIRA, 2007, p. 451). Associa-se à dimensão passiva da cooperação, desse modo, toda a gama de deveres e obrigações de cunho cooperativo lastreados em imposições legais, bem como o imperativo da lealdade federal tão alardeado pelos tribunais constitucionais. ${ }^{59}$

Hesse (1998, p. 212) oferece uma formulação mais elaborada para a lealdade federal (Bundestreue) no Direito alemão, denominando-a de princípio da conduta amistosa federativa, segundo o qual a Constituição estabelece para a federação não apenas correção

${ }^{59}$ Uma breve explanação sobre o tratamento jurisprudencial do princípio da lealdade federal em alguns países se faz conveniente para melhor compreensão do tema. Não há uma formulação expressa da lealdade federal na Constituição alemã, ainda que seus influxos sejam percebidos em órgãos como o Conselho Federal (art. 50 da Lei Fundamental alemã), por meio do qual podem os Estados influenciar na gestão federativa ou em figuras de gestão como as citadas por Maurer (2006, p. 632-635): autoridades comuns para administração financeira, autoridades comuns dos estados, grêmios de coordenação e corporações administrativas comuns. Tal fato não impede que o Tribunal Constitucional daquele país encare a lealdade federal como um princípio de significado fundamental para a ordem estatal-federal. Para Hesse (1998, p. 214), todavia, o princípio da conduta amistosa, não escrito, decorrente de formulações jurisprudenciais e, bem por isso, considerado como "norma constitucional imanente", perde força em relação a outros mandamentos constitucionalmente positivados no ordenamento alemão, devendo-se ter cuidado na sua utilização como supedâneo para solução de conflitos federativos, já que essa função cabe precipuamente à Corte Constitucional com fundamento primeiro nas normas positivadas.

Note-se que interessantes parâmetros de aplicação do princípio da lealdade federal (Bundestreue) surgem da experiência do Tribunal Constitucional Alemão. Em 1961 a Corte rejeitou a invocação do Land Hessen para o desempenho de competência atribuída originariamente pela Constituição ao poder central (reestruturação do território federal como base no art. 29 da Lei Fundamental) (BVerfgGE 13, 54-75/76). O Land Hessen viu suas pretensões frustradas porque, de acordo com o Tribunal, a lealdade federal não cria novos laços jurídicos, apenas disciplina o modo como direitos e deveres já existentes devem ser exercidos, disciplinando a interpretação de obrigações de cooperação federativa definidas pelo texto constitucional. (SILVEIRA, 2007, p. 285)

A Suprema Corte Norte Americana, por sua vez, apresenta uma jurisprudência majoritariamente posicionada em prol da divisão quase estanque das competências atribuídas constitucionalmente às unidades federadas, concedendo pouco espaço para a defesa da cooperação federal (ver nesse sentido Missouri vs. Holland, 1920, Nevada versus Hall, 1979, United States versus Darby, 1941, dentre outros). Pontualmente, a Corte Norte Americana foi capaz de reconhecer a lealdade federal como fundamento para solução de alguns conflitos (ver McCulloch versus Maryland, 1819, Prudential Insurance Company versus Benjamin, 1946, South Dakota versus Dole, 1987, dentre outros). Tal como leciona Silveira com o apoio de Pergola (2007, p. 302), a experiência norte-americana concerne, fundamentalmente, à solução de conflitos de competências, especialmente em zonas cinzentas em que as interferências recíprocas demandam um posicionamento do tribunal que, normalmente, se vale de um "juízo de inconstitucionalidade do exercício de um poder que em si mesmo legítimo redunda ilegítimo pelas conseqüências que dele se depreendem".

Já no Supremo Tribunal Federal brasileiro, a questão da cooperação federal, embora pouco mencionada expressamente como um princípio solucionador de controvérsias, encontra-se diluída em temas relativos à tributação e divisão de competências. Existe, por exemplo, ampla jurisprudência do Tribunal que repudia a guerra fiscal entre os Estados, em uma clara demonstração de que certas condutas, quando prejudicam o sistema federativo, devem ser evitadas, ou seja, trata-se da cooperação enquanto proibição de agir em detrimento das demais unidades federativas (nesse sentido ver ADI-MC 3936/PR, ADI 2.548/PR, ADI-MC 1.999/SP, ADI 467/DF e inúmeros outros julgados). 
exterior no cumprimento de seus deveres jurídico-estatais, mas a constante dedicação a uma boa e amistosa conduta no contexto federativo.

Integram a dimensão passiva situações como a participação obrigatória dos Municípios nas regiões metropolitanas ou o impositivo repasse de receitas tributárias entre entes federados prevista na Constituição de 1988, assim como a atuação concertada das unidades políticas na prestação de serviços de saúde e educação (arts. 198 e 211 do Texto Constitucional em vigor, respectivamente).

A dimensão ativa da cooperação federal representa a esfera em que prevalece a vontade dos envolvidos como determinante da conjugação de esforços. Aqui não há que se falar em obrigação de cooperar, cabendo à livre vontade dos interessados determinar quando e em que termos irão compartilhar suas capacidades.

Limita-se a Constituição ou a lei, nesse caso, a autorizar a cooperação e delimitar a forma procedimental (e demais condições) em que ocorrerá, deixando a iniciativa para sua formalização ao alvedrio das entidades políticas. O exemplo clássico brasileiro são os consórcios públicos e convênios de cooperação, bem como as transferências voluntárias de receitas entre entes federados.

Ao final, oferece-nos Silveira (2007, p. 455) uma perspectiva procedimental da cooperação, um "modelo concertado de planeamento e gestão das políticas públicas, que tem como resultado soluções discursivamente validadas".

Como instância de decisão concertada, a cooperação atesta sua grande proximidade com a questão democrática e com a busca por soluções de problemas de forma concatenada, discursiva, aproximando as entidades periféricas das decisões centrais e o centro decisório dos problemas subnacionais, a construir, assim, uma unidade dinâmica que não se confunde com qualquer tipo de centralização.

O federalismo necessita, assim, combater as tendências centrífugas, limitar a competição entre os entes políticos e atingir um equilíbrio entre autonomia e interdependência que mantenha a unidade na heterogeneidade própria dos Estados Compostos.

A cooperação fortalece os laços federativos e, em consequência, os vínculos políticos do Estado. Contudo, sua eficácia e solidez caminham paralelamente à experiência histórica e às tentativas e erros presentes na evolução de cada Estado Federado. 
Os próximos itens do trabalho cuidarão para que a dimensão histórica do federalismo brasileiro possa ser perscrutada de modo que os condicionantes nela presentes possam ser dimensionados na gestão compartilhada dos serviços de saneamento básico.

\subsubsection{O federalismo brasileiro: idiossincrasias que afetam a gestão compartilhada}

Para que os fundamentos jurídico-constitucionais da gestão compartilhada possam ser sentidos em sua plenitude, será aconselhável empreender uma rápida incursão na evolução do federalismo brasileiro e na compreensão das características concretas e históricas de sua formação.

Não há o desejo da descrição completa de uma história do federalismo pátrio. Ocorre que, sendo a gestão compartilhada um produto do modelo federativo, suas possibilidades de sucesso dependem do exame da eficácia mínima das normas que o instituem. Este exame, por sua vez, não se realiza sem a atenção ao processo formativo e evolutivo do nosso Estado e de nossa sociedade política.

O pano de fundo normativo dessa abordagem, dado em parte pela Lei $n$. 11.445/2007, traz como elemento inspirador o fato da valorização da prestação local dos serviços (pelos Municípios), ainda que a referida lei não tenha sido completamente clara a esse respeito (tema que será tratado adiante).

É justamente o maior destaque dado à valorização de competências aos Municípios que traz à tona os variados desdobramentos institucionais presentes na questão. A assunção de competências implica a construção de uma estrutura administrativa e gerencial compatível com as responsabilidades transferidas.

Algumas questões fundamentais pairam sobre esta discussão: é o federalismo brasileiro marcadamente centrípeto desde suas origens, a ponto de invalidar qualquer tentativa de alocação de competências administrativas relevantes nos entes locais (ao menos naqueles economicamente mais fracos)? A gestão compartilhada, nesse contexto, é mecanismo de reprodução dessa centralização ou meio para o fortalecimento da descentralização responsável dos serviços públicos? 
Para que a análise almejada não perca seu foco, é possível congregar algumas perspectivas que, bem tangenciadas, cumprirão com os objetivos do presente item do trabalho. Tais perspectivas se baseiam em características fundamentais da federação, como conceito político, jurídico e institucional, e sua análise terá como linha mestra a cooperação e a coordenação entre os entes federados:

(i) Toda federação representa um pacto político-constitucional entre os diferentes integrantes do regime federativo. Esse pacto se assenta em determinados pressupostos a conformar uma "situação federalista" cuja existência pode ditar o sucesso ou o fracasso do modelo adotado. O exame da existência de tais pressupostos, no caso brasileiro, conferirá robustez crítica à análise das práticas de gestão compartilhada de saneamento.

(ii) O federalismo, mais do que um sistema jurídico de organização do Estado, corresponde a uma categoria socioinstitucional que implica uma visão global da sociedade e da maneira como esta encara o trato político e a gestão dos assuntos públicos. O comportamento da sociedade política e o grau de democracia nela existente interferirão diretamente na realização prática do federalismo e, em especial, na concretização do compromisso de cooperação federal, pressuposto da gestão compartilhada do saneamento básico.

Bem afirma Abrucio (2006, p. 90-91), com o apoio de Burgess (1993), que "toda federação deriva de uma situação federalista", conformada pela comprovada existência de heterogeneidades de caráter territorial, étnico, linguístico, socioeconômico (desigualdades regionais), cultural e político (disputas internas entre as elites).

Nesse contexto, somente o pacto federal permitiria a manutenção da unidade da nação e da estabilidade social. De outro modo, o Estado se esfacelaria em disputas internas.

Acrescenta Abrucio (2006, p. 91) que, ao lado das heterogeneidades, a solidez de um discurso e uma prática em prol da unidade na diversidade é condição para a existência de um Estado Federal.

Para muitos, a federação brasileira nasceu sem que uma "situação federalista" real e delineada existisse. O Estado Federal brasileiro foi, sob essa perspectiva, resultado de uma transição acrítica de um Estado Unitário (período imperial) para uma cópia mal 
realizada do exemplo norte-americano. Uma suposta maldição de origem, que determinaria toda a posterior evolução do nosso federalismo.

Essa posição não é unânime. O período do Brasil Império testemunhou calorosas discussões em torno da definição estrutural do Estado. Para Silveira (2007, p. 50), o ideal político do federalismo antecedeu a Federação instituída com a proclamação da República em 1889:

\begin{abstract}
Não se consegue perceber o histórico federal brasileiro, e sobretudo os recentes desdobramentos da redemocratização, a partir do entendimento dominante segundo o qual toda a tradição sociológica, jurídica e administrativa que teria desaguado na Constituição republicana de 1891 seria a do Estado Unitário e da centralização portuguesa - e que tal maldição da origem explicaria a fatalidade do desfecho, isto é, as conseqüentes fragilidades institucionais brasileiras. Tal entendimento não só resulta improcedente (na medida em que a dispersão e a disparidade dominaram os primeiros três séculos e a federação, como bem elucidou Rui Barbosa, sendo em princípio uma medida essencialmente liberal, correspondeu, nas circunstâncias vigentes no Brasil de então, a uma reforma eminentemente conservadora, tendente a evitar o separatismo anunciado), como também não ajuda a romper com os legados autoritários dos dois períodos ditatoriais do sec. XX (na medida em que percepciona o centralismo como um elemento natural e inarredável da sistemática brasileira). (Grifos do autor)
\end{abstract}

A concepção adotada pela autora é a de que, em suas origens, já no período imperial, a Federação brasileira encontrava supedâneo concreto na conformação sociopolítica do Estado então existente.

De fato, o Brasil do século XIX, seja no Primeiro Império, no período da Regência, no Segundo Império ou no despertar da República, presenciou manifestações concretas de heterogeneidades regionais, muitas delas de caráter separatista e revolucionário.

As diferenças regionais eram, e são, uma realidade inegável do Estado brasileiro e, no período em apreço, a força das elites provinciais provocava tensões de caráter desagregador (muitos foram os exemplos de revoltas e revoluções de caráter separatista).

Em muitos aspectos estava configurada a situação federalista alardeada por Abrucio (2006) como pressuposto do Estado Federal.

Os debates da Assembleia Constituinte de 1823 comprovam um viés federalista no discurso político de muitos dos constituintes, os quais defendiam a ausência de contradição entre a forma de governo monárquica, o regime federal e a necessidade de maior autonomia para as províncias. 
As concepções centralistas, de seu lado, encaravam a monarquia unitária como a única opção para a manutenção da unidade e do interesse geral da nação. ${ }^{60}$

Obviamente, não existia uma noção clara do federalismo e seus efeitos. O modelo federal era associado ao sistema confederativo, em que os Estados Federados permaneciam com grande parte de sua soberania, deixando uma esfera de poder reduzida para a União.

As evoluções trazidas pelo modelo federal norte-americano, que permitiam uma conexão mais sólida entre União e Estados, ainda não haviam sido propriamente divulgadas a fim de subsidiar as discussões constituintes.

De qualquer modo, a Constituição outorgada de 1824, de caráter unitário, frustrou as pretensões dos federalistas, mas não impediu que manifestações significativas de poder local e regional fossem cedidas nos anos vindouros por meio da edição do Código de Processo de 1832 e do Ato Adicional de $1834 .{ }^{61}$

Em razão da edição da Lei de Interpretação do Ato Adicional, que retirou atribuições significativas das províncias, as décadas subsequentes testemunharam um recrudescimento do ímpeto descentralizador.

${ }^{60}$ Coser (2008, p. 38-39) fornece um retrato fidedigno das discussões sobre a nova Constituição do Império: "Nos debates constituintes de 1823, a corrente centralizadora mencionava com frequiência a incompatibilidade entre a forma de governo monárquica e o arranjo federal/confederativo. Na sessão de 17 de setembro de 1823, o deputado Manoel Souza França rechaçava a introdução do termo federação na Constituição". Segundo o discurso do deputado "o que nos cumpre averiguar é, se rebus sic standibus, podemos nós admitir na constituição do império essa federação? Decerto que não, porque quando os povos do Brasil se deram as mãos, e proclamaram sua independência foi com a pronunciação de um governo monárquico, que se estendesse a todas as partes do império; e não se restringiram a haver constituições parciais e internas em cada uma das províncias, sobre as quais se estabelecesse depois a constituição geral de estados, que em tal caso devia seguir-se. Por isto somente é que voto contra a emenda." Do lado dos federalistas, entendia-se como plenamente cabível a convivência da monarquia com a federação. Nos termos do discurso do deputado Montezuma, "se a experiência nos mostra que de reinos unidos se forma um todo monárquico federal; se de províncias unidas se forma um todo republicano; por que igualmente de províncias confederalmente unidas não formamos um todo monárquico representativo? Onde está aqui o absurdo, pedra de escândalo, que tanto irritou o delicado sensório do ilustre deputado todo ocupado e, tão ardentemente, em defender o bem geral? [...] As províncias confederadas formarão uma monarquia federativa; se eles, porém, souberem as instituições democráticas, as províncias confederas formarão um república. Não é portanto característica das repúblicas a confederação; muitas existem sem tal instituição; não é igualmente essencial à monarquia o não serem federativas suas partes, porque muitas existirão sendo-o".

${ }^{61}$ O Código de Processo possibilitou que importantes figuras da administração da justiça fossem eleitas pelos munícipes: o juiz de paz, o promotor, o juiz municipal e o júri popular. O Ato Adicional de 1834, por sua vez, transformou os Conselhos Provinciais em assembleias provinciais e aumentou significativamente o rol de matérias atribuídas à sua deliberação, incluídos alguns dos temas que antes haviam sido delegados às municipalidades por meio do Código de Processo. Às assembleias cabiam, dentre outros assuntos: a organização da divisão judiciária da Província, o controle das competências do juiz de paz, do promotor, do juiz municipal e do júri popular, a fixação das despesas do município, das contribuições destes para a Província e dos impostos incidentes sobre a população. 
Vê-se que as disputas entre centralizadores e descentralizadores durante o Império, respaldadas pelos movimentos separatistas verificados no século XIX e pelo aumento da força política das elites regionais, conferem robustez à tese de que o federalismo brasileiro não é uma simples cópia do norte-americano, possuindo traços de originalidade e legitimidade histórica.

A ideia acima veiculada não é, com efeito, incorreta, embora demande maior precisão no que toca à compreensão do arranjo de forças políticas vigente no país.

Constatava-se, à época, que a sociedade brasileira, tal como organizada, não possuía propensão inequívoca ao regime federativo. Esse traço peculiar da estrutura política brasileira se revelou um dos principais pontos de influência do sistema federal pátrio em toda a sua história.

Mais do que uma forma jurídica de organização do Estado, o federalismo deve ser encarado como um postulado de funcionamento do próprio organismo social.

Baracho (1982, p. 16) esclarece que, “com a denominação L'etre fédéraliste, Duclos insiste com a ideia de que o federalismo não é apenas uma receita política ou jurídica, mas um princípio geral de organização social, que expressa certa tendência cultural, de um estilo de vida".

De maneira semelhante, para Levi (1998), o termo federalismo se presta a designações distintas na cultura política: refere-se tanto à teoria do Estado Federal (modelo constitucional que ilustra os aspectos fundamentais de estrutura e funcionamento dessa forma de Estado) quanto a uma visão global da sociedade. Ao destacar a importância desta última perspectiva, que implica uma compreensão abrangente de um dado corpo social, afirma o autor:

\footnotetext{
De fato, de um lado, o conhecimento de um Estado não é completo se não se toma em consideração as características da sociedade, que permitem manter e fazer funcionar as instituições políticas. Portanto, se o Estado Federal é um Estado dotado de características próprias, que o distinguem de outro tipo de Estado, devemos conjeturar que tenham algum caráter federal os comportamentos daqueles que vivem nesse Estado. (LEVI, 1998, p. 475)
}

Ainda nos dizeres de Levi (1998, p. 475), compreende-se esse segundo modo de ver o federalismo como "uma doutrina social de caráter global como o liberalismo ou o socialismo, que não se reduz, portanto, ao aspecto institucional, mas comporta uma atitude autônoma para com os valores, a sociedade, o curso da história e assim por diante". 
No caso brasileiro, o que se viu foi, de um lado, a existência de algumas condições gerais propícias ao arranjo federal (elevadas disparidades regionais potencializadas pelos interesses das respectivas elites), mas uma organização sociopolítica marcada por particularismos que impediam o florescimento de uma sociedade verdadeiramente federal.

Schwartzman (2007) afirma que o debate a respeito do grau centralização e descentralização presentes no Brasil de então se encontra mal colocado. Para o autor, nenhum dos movimentos se verificava de forma preponderante, convivendo o Estado com expressões centralizadoras e descentralizadoras, as primeiras patrocinadas por um governo central de caráter hierárquico e as segundas, por um poder local difuso e autônomo:

\footnotetext{
Não ocorria uma das coisas, mas as duas. De um lado, um poder político centralizado e hierárquico, que não dependia de bases locais de sustentação, apoiando-se na própria máquina administrativa governamental para subsistir e se afirmar. De outro, um poder privado autônomo e difuso, que só adquiria expressão política quando era cooptado pelo Estado, e que entrava em uma trajetória de conflito quando pretendia se articular minimamente que fosse, como força política autônoma e representativa de seus interesses. (SCHWARTZMAN, 2007, p. 179)
}

A ausência de canais de comunicação entre a autoridade política constituída e as lideranças locais (representativas de um poder privado, diluído e atomizado) prejudicou a construção de bases sólidas para uma política de caráter regional e nacional, gerando um discurso político acentuadamente retórico e abstrato, que tentava simular uma integridade nacional inexistente. Para Schwartzman (2007, p. 178), um discurso quase esquizofrênico, "que separava o dito e escrito nos livros e leis da realidade em que o poder político realmente se apoiava".

A difícil integração entre os estratos políticos brasileiros é uma nota que pode ser estendida em maior ou menor medida a toda a experiência política de nosso país, embora não tenha sido, por certo, o único determinante do federalismo.

Não sem razão, a Primeira República foi marcada por um modelo federal acentuadamente dual, caracterizado por um grande distanciamento e muitas disputas entre União e Estados.

A Constituição de 1891 favorecia esse arranjo uma vez que estabelecia limites rígidos de interação entre os entes políticos. A Carta Constitucional facultava a cada 
Estado todo e qualquer poder ou direito que não lhes fosse negado por cláusula expressa ou implicitamente contida nas cláusulas constitucionais (art. 65, § $2^{\circ}$ ).

Um tênue incentivo ao relacionamento federal residia no n. 1 do art. 65 do Texto Constitucional, que facultava a celebração entre os entes de ajustes e convenções sem caráter político. Expediente pouco utilizado e ainda submetido ao controle do Presidente da República:

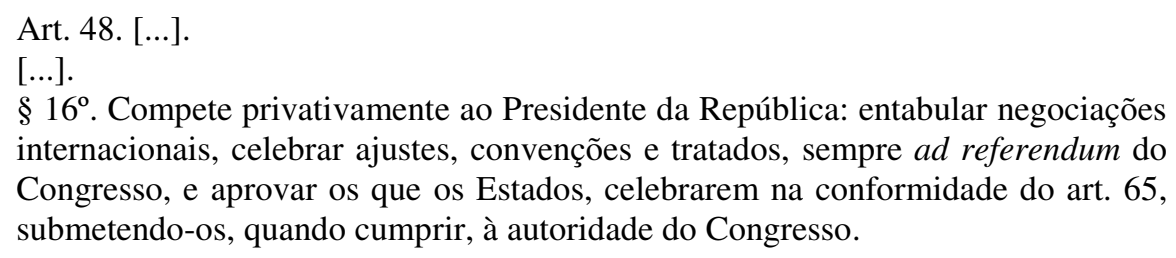
internacionais, celebrar ajustes, convenções e tratados, sempre ad referendum do Congresso, e aprovar os que os Estados, celebrarem na conformidade do art. 65, submetendo-os, quando cumprir, à autoridade do Congresso.

A União, de seu lado, não poderia intervir nos negócios peculiares aos Estados, salvo (art. $6^{\circ}$ ): para repelir invasão estrangeira, ou de um Estado em outro; para manter a forma republicana federativa; para restabelecer a ordem e a tranquilidade nos Estados, à requisição dos respectivos governos e para assegurar a execução das leis e sentenças federais.

Cabia ao Estado prover, por conta própria, as necessidades de seu governo e administração. A União, somente prestaria socorros ao Estado que, em caso de calamidade pública, assim solicitasse (art. $5^{\circ}$ ).

Determinava ainda o Texto Constitucional que os Estados seriam organizados de forma a assegurar a autonomia dos Municípios em tudo quanto respeitasse ao seu peculiar interesse (art. 68).

O exercício exacerbado das autonomias conferidas pela Constituição gerou abusos generalizados. Múltiplas intervenções federais autoritárias e desnecessárias se verificaram nos Estados. ${ }^{62}$ Estes, por sua vez, controlados por oligarquias regionais, aproveitaram-se do elevado controle que detinham sobre as escolhas políticas locais para direcionar o processo eleitoral em favor de seus interesses. Não existia uma concepção política cooperativa a gerir o país.

\footnotetext{
${ }^{62}$ Segundo Silveira (2007, p. 55), “todavia os militares que fizeram a república não estavam habituados à fórmula federal do self-rule plus shared rule, nem às regras mais elementares de Estado de direito, nomeadamente aquela segundo a qual todo poder encerra um dever - o de exercitá-lo apenas em condições que legitimem o seu uso e o de não deixar de exercitá-lo, desde que a situação o reclame. Por isso, o instituto da intervenção federal nos Estados e a conseqüente deposição dos governadores pelas armas federais foi transformado no mais poderoso instrumento político do arbítrio".
} 
Acrescente-se o fato de que a principal fonte de renda dos Estados residia no imposto sobre exportação de mercadorias (art. $9^{\circ}$, n. $1^{\circ}$, da Constituição), circunstância que favorecia as unidades federativas tradicionalmente exportadoras, hierarquizando economicamente a federação brasileira. (SILVEIRA, 2007, p. 61)

Como dito, a Carta Constitucional, tal como delineada, favorecia esse desenho institucional. Tratava-se do modelo de repartição clássica de competências, inaugurado pelo Texto norte-americano de 1787, que compreendia a dual distribuição dos poderes enumerados à União e dos poderes reservados aos Estados (HORTA, 1999, p. 15)

De um desenho acentuadamente dual o federalismo brasileiro evolui, a partir da década de 1930, para uma modelo fortemente centralizado, atenuado apenas por determinações pontuais das Constituições de 1934 e 1946, esta última em vigor até a ditadura militar de 1964.

Na década de 1930 presenciou-se a ascensão de Vargas ao poder. Nesse período, foram produzidas duas Constituições: a de 1934 e a de 1937.

A primeira é considerada por muitos como a precursora no Brasil da moderna divisão de competências federativas, já que adotou a solução intermediária de deferir aos Estados a legislação estadual supletiva ou complementar enumerada no Texto Fundamental $\left(\mathrm{CF} / 1934\right.$, art. $\left.5^{\circ}, \S 3^{\circ}\right)$. (HORTA, 1999, p. 15)

É vista também como a primeira Carta a conter determinações que superavam o federalismo dual tendo em vista que previa competências da União que favoreciam diretamente aos Estados, tais como organização do serviço nacional de combate a grandes endemias e de combate a secas. Facultava ainda à União e aos Estados celebrar acordos para a melhor coordenação e desenvolvimento dos respectivos serviços, e, especialmente, para a uniformização de leis, regras ou práticas, arrecadação de impostos, prevenção e repressão da criminalidade e permuta de informações (art. $9^{\circ}$ ).

Mais uma vez a Constituição dispôs que os Municípios seriam organizados de forma que lhes ficasse assegurada a autonomia em tudo quanto respeitasse ao seu peculiar interesse e, especialmente, à eletividade do Prefeito e dos Vereadores da Câmara Municipal, à decretação dos seus impostos e taxas, à arrecadação e aplicação das suas rendas e à organização dos serviços de sua competência (art. 13).

No que toca à repartição tributária, determinou a capacidade da União e Estados de criar outros impostos, além dos que lhes eram atribuídos privativamente (art. 
10), sendo que, do produto dessa arrecadação (realizada pelos Estados), $30 \%$ seriam entregues à União e 20\% aos Municípios de onde tivessem se originado.

Embora contivesse determinações concretas em favor de um federalismo mais integrado, na prática, a Carta de 1934 pouco contribuiu para a consecução de uma postura cooperativa entre os entes, já que a realidade político-administrativa cada vez mais se organizava em torno da centralização. A hipervalorização do poder central prenunciava o regime totalitário que se avizinhava.

De fato, a subsequente Lei Fundamental de 1937 foi, inquestionavelmente, um documento de caráter autoritário. Inaugurou o Estado Novo e com ele o esvaziamento de qualquer relacionamento interfederativo, a despeito do disposto em seu art. 29, que possibilitava o agrupamento de Municípios para a instalação e exploração de serviços públicos comuns.

Como informa Almeida (2007, p. 22-23), o Congresso foi fechado, os Estados foram praticamente reduzidos à condição de províncias, pois entregues ao controle de interventores federais, os partidos políticos foram extintos e as eleições suspensas por prazo indeterminado. A mediação política deixou de ser realizada por meio do processo eleitoral, contando exclusivamente com a arbitragem desenvolvido pelo Governo Central e sua burocracia.

De 1930 a 1945 criou-se uma considerável estrutura federal de intervenção social, por meio da expansão de direitos sociais sob a bandeira do corporativismo, e de intervenção e regulação do Estado na economia, por meio da produção de bens e serviços. Foram instituídas empresas públicas e entidades encarregadas de controlar mercados como o do café, o do açúcar e o do álcool. Iniciou-se uma prática de intervenção econômica do Estado (por meio do incentivo à industrialização do país) que conformou o padrão desenvolvimentista de atuação estatal que acentuou ainda mais o papel do poder central no contexto federativo.

Como se vê, pouca evolução se verificou nesse período no que toca à dinâmica da cooperação Federal.

O período iniciado em 1946, por sua vez, tem o privilégio de ser reconhecido como aquele que propiciou os fundamentos da moderna democracia no Brasil. (SANTOS, 2007, p. 39) 
Pela primeira vez, partidos políticos de abrangência nacional foram estabelecidos (processo estimulado pela Lei Agamenon, segundo a qual apenas partidos com representatividade nacional poderiam participar das eleições), criando-se condições para discussão de temas de maior abrangência e importância, fatos que refletiram em maior participação política da população. ${ }^{63}$

O federalismo puramente dual do início da República deu espaço à densificação da cooperação entre os entes que ocorreu sob a forma, sobretudo, de órgãos e entidades de desenvolvimento regional (regionalismo administrativo). (HORTA, 1999, p. 19)

Por meio da implantação de políticas de investimento, incentivos fiscais e gastos programados, tais órgãos buscavam a valorização de regiões do país carentes de infraestrutura básica e, em alguns casos, afligidas por contingências naturais ou socioeconômicas como a seca (polígono das secas) ou o grande distanciamento dos centros industriais brasileiros (região amazônica).

No que toca especificamente ao regionalismo administrativo, interessante notar que foi privilegiado como modelo para a sua implantação a criação de entidades autárquicas ou empresas públicas federais, subordinadas ao planejamento efetuado pela União. Com isso, visava-se, certamente, ao maior controle da ação administrativa minimizadora de disparidades regionais, uma vez que esta seria executada primordialmente pelo ente que aglutinava (e ainda aglutina) do ponto de vista físico ou territorial toda a extensão do universo federativo.

Apesar dos avanços derivados dos incentivos da Carta de 1946, não houve completa consolidação da cooperação federativa, ficando esta mais adstrita ao incremento de transferências financeiras e investimentos controlados pela União. ${ }^{64}$

63 Segundo Santos (2007, p. 40), o Brasil pós-Segunda Guerra testemunhou um grande processo de incorporação político-eleitoral: "Se ao longo de toda a República Velha o comparecimento eleitoral nunca ultrapassou a marca de $5 \%$ da população adulta, feito excepcional nas eleições de 1930, já nas eleições de 1945 este mesmo indicador subiu para 13,4\%, chegando a $20 \%$ ao final do período com as eleições de 1962. Se juntarmos a estas informações a prevalência da representação proporcional, além da criação e atuação da Justiça Eleitoral, cuja finalidade foi a de garantir a lisura do pleito eleitoral, pode-se dizer que período 1946-1964 caracterizou por uma verdadeira ruptura político-institucional do país."

${ }^{64} \mathrm{O}$ retorno da democracia e sua convivência com uma burocracia ainda fortemente fundada no governo federal acabou criando tensões entre centralização e descentralização. Um típico exemplo das tensões presentes nessa fase de evolução do federalismo reside na contraposição de um executivo centralizador com um Congresso atento às questões regionais. Santos (2003, p. 56), contrariando o entendimento geral da literatura política a respeito do período de 1945 a 1964, afirma uma atuação independente do Congresso no período em questão, justamente para contrabalancear o Executivo forte característico desse momento histórico: "A reiterada crítica de que os parlamentares do período 1945-1964 não possuíam visão nacional, 
A Revolução de 1964 deu início, como se sabe, ao regime militar e com ele a um momento institucional notoriamente centrípeto e de esvaziamento ainda mais intenso do pacto federativo.

Embora a Constituição de 1967 tenha apresentado possibilidade de união de esforços entre Municípios mediante pacto convenial, é possível afirmar, sem receios, que o federalismo brasileiro assentou seu pilar fundamental no poder central, representado pela União, tudo isso como parte de uma inequívoca estratégia de controle político e econômico dos mais diversos estratos sociais.

O efeito natural dessa postura foi a construção de um sistema federal fortemente subordinado ao poder central, em que a situação de dependência dos demais entes, notadamente os Municípios, foi acentuada, de um lado, para possibilitar maior controle da sociedade pelo regime de exceção e, de outro, para legitimar tal regime por meio de políticas clientelistas.

Almeida (2007, p. 25) esclarece que, sob o comando dos militares, o Brasil presenciou um novo ciclo desenvolvimentista, com acentuada expansão de empresas públicas produtoras de bens e serviços e de políticas de promoção industrial. Na perspectiva política, a supressão das eleições para os Estados, capitais e outros Municípios aprofundou a centralização.

Vê-se que o federalismo brasileiro apresentou, no curso de sua evolução, caráter preponderantemente centrípeto e baixa participação democrática, pontuado por manifestações esparsas de cooperação e abertura política.

Após a descrição geral dos principais aspectos que caracterizaram nosso Estado Federal até a redemocratização da década de 1980, convém delinear considerações apartadas a respeito das práticas federalistas trazidas pela Constituição de 1988.

Avaliou-se como a Constituição de 1988 lidou com o tema do federalismo de cooperação, oferecendo um novo contexto para a gestão de serviços públicos, ainda que as heranças históricas dos períodos anteriores se encontrassem presentes como importantes

transformando-se em meras porta-vozes de interesses particularistas estaduais, não leva em consideração a que esta foi precisamente a única maneira de fazer valer uma pálida sombra de federalismo, naquilo que federalismo significa de respeito às vontades das unidades que compõem a federação. Por isso mesmo, o formalismo das relações entre o Executivo e o Legislativo, estabelecendo inúmeros controles do último sobre o primeiro, era eficazmente ativado sempre que uma política do governo central de maior abrangência implica sérios efeitos para as unidades federadas". 
balizas para a realização concreta da cooperação federal e, em especial, da prestação compartilhada dos serviços de saneamento.

\subsubsection{A Constituição de 1988: mecanismos de relacionamento federativo e sua eficácia normativa}

A Constituição de 1988 buscou conferir organização sistêmica aos dispositivos norteadores das relações interfederativas, tratados de forma fragmentária pelas cartas anteriores (HORTA, 1999, p. 21), e adotou mecanismos tanto de cooperação passiva quanto de indução à cooperação ativa.

A primeira categoria, como visto, abrange institutos que congregam entes federados em atuação conjunta, independentemente de sua vontade. As regiões metropolitanas figuram como exemplo principal dessa modalidade, já que lei complementar estadual define a área metropolitana e os Municípios dela integrantes, inserindo-os em um contexto jurídico renovado e, em certa medida, cogente no que toca à obrigatória participação nos processos de tomada das decisões metropolitanas.

A segunda categoria corresponde às situações em que os entes voluntariamente aderem a uma situação cooperativa. Exemplo primordial reside nos consórcios e convênios de cooperação em que o compartilhamento de competências, funções e serviços é possibilitado pela concordância e aceitação recíproca dos interessados.

Além das regiões metropolitanas e dos consórcios e convênios de cooperação, tratados com maior profundidade no decorrer deste trabalho por integrarem o conceito de gestão compartilhada de saneamento ora adotado, a Carta de 1988 apresenta outras determinações e dispositivos que disciplinam as relações federativas.

O tratamento dado às regiões merece destaque. Segundo a Constituição, as regiões constituem um complexo geoconômico e social no qual a União articulará sua ação com vista a reduzir desigualdades sociais (art. 43 da CF). As condições de funcionamento das regiões são determinadas por lei complementar federal que disciplinará as condições para integração de regiões em desenvolvimento e a composição dos organismos regionais 
que executarão, na forma da lei, os planos regionais, integrantes dos planos nacionais de desenvolvimento econômico e social, aprovados juntamente com estes. ${ }^{65}$

Outro ponto importante de evolução se deu com a adoção de um sistema de divisão de competências mais complexo que o das Cartas anteriores.

As competências comuns descritas no art. 23 da Constituição, associadas ao modelo de competências legislativas concorrentes (art. 24), representam uma superação em relação ao federalismo dual clássico de grande parte dos textos anteriores. Para Horta (1999, p. 17),

a repartição de competências, estruturada na Constituição Federal de 1988, reflete as novas tendências do federalismo e, na concepção constitucional, é visível a influência recebida da técnica de repartição de competências da Lei Fundamental da Alemanha de 1949, que o Anteprojeto de Constituição Federal da Comissão Afonso Arinos.

Exemplos importantes da maior predisposição do Texto Constitucional para a cooperação são as política de saúde e educação. Em ambos os casos (arts. 198 e 211

${ }^{65}$ São incentivos regionais descrito expressamente pelo Texto Constitucional: igualdade de tarifas, fretes, seguros e outros itens de custos e preços de responsabilidade do Poder Público; juros favorecidos para financiamento de atividades prioritárias; isenções, reduções ou diferimento temporário de tributos federais devidos por pessoas físicas ou jurídicas; e prioridade para o aproveitamento econômico e social dos rios e das massas de água represadas ou represáveis nas regiões de baixa renda, sujeitas a secas periódicas.

Por óbvio o conceito de gestão compartilhada adotado neste trabalho não se confunde com o das regiões acima descrito: sua forma de constituição e objetivos são distintos. A abrangência da gestão compartilhada do saneamento básico é, com efeito, mais restrita, tendo por meta, no caso do saneamento, a gestão de um serviço público, enquanto as regiões representam uma atuação socioeconômica mais ampla, valendo-se de mecanismos de incentivo.

A afirmação das diferenças de forma, constituição, abrangência e objeto dessas figuras não é obstáculo para a formulação de aproximações, se não práticas, ao menos teóricas que possam contribuir para a melhor compreensão da gestão compartilhada.

Nesse sentido, os ensinamentos de Bercovici (2003, p. 239-241) ao tratar do desenvolvimento regional: "O desenvolvimento regional, assim como o desenvolvimento em geral, não é um fim em si mesmo. O seu grande objetivo é a elevação das condições sociais de vida e a redução, a mínimos toleráveis, das diferenças nas oportunidades econômicas e sociais entre os habitantes das várias regiões brasileiras, não o mero crescimento do PIB ou da produtividade industrial. A igualação das condições sociais de vida deve ser o fundamento das políticas nacionais de desenvolvimento e, especificamente, de desenvolvimento regional. [...] A igualdade, assim, recebe uma nova dimensão no federalismo cooperativo: a proibição de discriminação territorial passa a ser um de seus conteúdos essenciais. Ou seja, todos os habitantes de um determinado Estado Federal têm direito aos mesmos serviços públicos essenciais, independentemente da região onde estejam." No caso da gestão compartilhada, a submissão de uma mesma região a um planejamento homogêneo e a regras padronizadas de gestão têm como objeto não apenas colocar em prática um serviço essencial (o saneamento), mas, em última análise, e à semelhança das figuras regionais citadas, promover equiparação das condições sociais dos cidadãos. 
respectivamente), a atuação conjunta entre União, Estados e Municípios é uma imposição da Lei Maior. ${ }^{66}$

Incontestável, ainda, no Texto de 1988, a sedimentação da posição do Município como unidade federativa, tendo se incumbido expressamente dos assuntos de interesse local. ${ }^{67}$ A previsão de um novo ator no jogo federativo, inegavelmente, aumenta a importância dos instrumentos de relacionamento entre os entes políticos.

A distribuição de competências realizada pela Carta de 1988 caracterizada pela maior atribuição de competências e responsabilidades aos Estados e Municípios redundou na óbvia necessidade de maior divisão de receitas tributárias.

A Constituição da chamada Nova República inovou significativamente na distribuição de receitas, seja atribuindo a capacidade de criação de impostos próprios para cada ente federado, seja determinando transferências obrigatórias de receitas entre as unidades.

A descrição empreendida certamente não esgota as possibilidades de prática cooperativa no Estado brasileiro. A cooperação é, com efeito, algo dinâmico, que deflui do jogo federativo nas suas múltiplas facetas.

Importa ressaltar que o atual Texto Constitucional apresenta importantes incentivos ao relacionamento cooperativo entre as unidades federadas, sendo essa informação um pressuposto relevante para a gestão compartilhada dos serviços de

\footnotetext{
${ }^{66}$ Nos termos do Texto Constitucional: “Art. 198. As ações e serviços públicos de saúde integram uma rede regionalizada e hierarquizada e constituem um sistema único, organizado de acordo com as seguintes diretrizes: I - descentralização, com direção única em cada esfera de governo; II - atendimento integral, com prioridade para as atividades preventivas, sem prejuízo dos serviços assistenciais; III - participação da comunidade. [...]

Art. 211. A União, os Estados, o Distrito Federal e os Municípios organizarão em regime de colaboração seus sistemas de ensino. [...]."

${ }^{67}$ Novamente segundo o Texto Constitucional: “Art. 30. Compete aos Municípios:

I - legislar sobre assuntos de interesse local;

II - suplementar a legislação federal e a estadual no que couber;

III - instituir e arrecadar os tributos de sua competência, bem como aplicar suas rendas, sem prejuízo da obrigatoriedade de prestar contas e publicar balancetes nos prazos fixados em lei;

IV - criar, organizar e suprimir distritos, observada a legislação estadual;

V - organizar e prestar, diretamente ou sob regime de concessão ou permissão, os serviços públicos de interesse local, incluído o de transporte coletivo, que tem caráter essencial;

VI - manter, com a cooperação técnica e financeira da União e do Estado, programas de educação infantil e de ensino fundamental;

VII - prestar, com a cooperação técnica e financeira da União e do Estado, serviços de atendimento à saúde da população;

VIII - promover, no que couber, adequado ordenamento territorial, mediante planejamento e controle do uso, do parcelamento e da ocupação do solo urbano;

IX - promover a proteção do patrimônio histórico-cultural local, observada a legislação e a ação fiscalizadora federal e estadual."
} 
saneamento justamente porque se assenta, em parte, nos fundamentos jurídicos da cooperação federal.

Todavia, as determinações da Carta de 1988 não são imunes a considerações críticas assentadas nos avanços modestos verificados na seara da cooperação em nosso país.

Para Bonavides (2004), a revolução federal brasileira somente ocorreria por meio de uma reestruturação do Estado em prol de um federalismo das regiões, dotado de eficácia institucional para suplantar as desigualdades internas. Do contrário, prevaleceria, segundo o autor, a prática de um federalismo de cooperação de viés autoritário próprio da história constitucional brasileira. ${ }^{68}$

De outro lado, a repartição de receitas proporcionada pela Constituição não seria suficiente para assegurar aos entes federados de menor porte a correspondente autonomia financeira para cumprimento de suas obrigações constitucionais.

Há razões de ordem prática e política que ajudam a entender por que a Constituição de 1988 apresentou, especialmente nos primórdios de sua vigência, pouca eficácia no que toca ao federalismo cooperativo.

Como se sabe, a Constituição atual é o ponto alto de um período de transição entre um regime autoritário e um regime democrático. A passagem para a redemocratização no Brasil seguiu um modelo denominado pela ciência política de "transição por transação". ${ }^{69}$ Nessas hipóteses, os agentes do regime autoritário, deliberadamente, introduzem uma agenda liberalizante, por meio da qual adquirem o poder de controle do processo de abertura, seu ritmo e condições de realização. Com isso conseguem direcionar a dinâmica de negociação entre regime e oposição, impondo limites e condições para as mudanças e permanecendo como uma força importante durante o

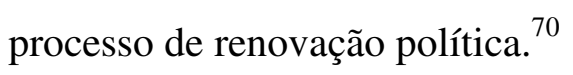

68 Para um aprofundamento da doutrina do autor a respeito do federalismo das regiões recomenda-se Bonavides (2004).

${ }^{69} \mathrm{Na}$ outra ponta dos processos de mudança política encontram-se os modelos de transição por colapso, representativos de uma alteração abrupta do regime vigente, caso de países como Grécia e Portugal.

70 Marenco (2007, p. 90),informa que a dinâmica transacional dependeria de alguns fatores: um regime autoritário estável e com base de apoio político consistente; neutralização de ameaças da esquerda e de correntes extremistas (ou seja, uma menor percepção de ameaça decorrente da sensação de derrota de grupos insurgentes), disposição da oposição democrática em aceitar as condições impostas pelos agentes autoritários; níveis reduzidos de mobilização social e habilidade das lideranças políticas para persuadir a conciliar os setores mais resistentes seja do regime, seja da oposição no que respeita às vantagens de uma transição pactuada. 
Acrescente-se que o processo de abertura para a democracia se deu em tempo maior se comparado com o de outros países em situação semelhante à brasileira (Argentina e Chile).

Segundo Marenco (2007, p. 101), a “extensão temporal e as regras da transição política brasileira implicaram atraso na conquista do Poder Executivo federal por partidos democráticos, bem como uma reabilitação política da direita autoritária [...]”. A direita autoritária revigorada politicamente pôde imiscuir-se em partidos de centro-esquerda e em sucessivos gabinetes presidenciais. Consequência inevitável foi o prolongamento e a permanência de instituições, elites e estruturas políticas próprias do regime anterior, que apresentavam, como incansavelmente descrito, caráter fortemente centralizador.

Com essas afirmações não se deseja dar azo a uma suposta falência da força normativa da Constituição de 1988 ou mesmo defender a superação da Constituição Jurídica pela Constituição Real. ${ }^{71}$

Ao contrário, entende-se, com supedâneo na doutrina de Hesse (1991, p.15), que a pretensão de eficácia das normas constitucionais não se identifica meramente com as condições concretas de sua realização. A norma constitucional representa um dever ser que procura imprimir ordem à realidade política e social.

A Constituição impõe tarefas e sua pretensão normativa se realiza quando a vontade de cumpri-las se faz presente no imaginário dos responsáveis pela ordem constitucional (trata-se da Vontade de Constituição - Wille zur Verfassung). (HESSE, 1991, p. 19)

Há um lugar comum que afirma ter havido, durante todo o período de vigência da Constituição de 1988, a descentralização financeira (repartição tributária) não acompanhada de uma correspondente descentralização administrativa.

Se é verdade que nos primórdios da Carta de 1988 a centralização se fez presente, é fato que muitas das administrações brasileiras voltaram-se, especialmente na década de 1990, para uma concepção descentralizada de gestão.

Sob o pálio do movimento de reforma do Estado, o Governo Federal buscou transferir inúmeras funções a Estados e Municípios, sendo exemplos dessas medidas: as

\footnotetext{
${ }^{71}$ A dualidade entre "Constituição Jurídica" e "Constituição Real” foi cunhada por Ferdinand Lassalle em 1862. Para o jurista, a constituição real, retrato verdadeiro da correlação de forças que rege a sociedade, supera e comprime a constituição jurídica, mero pedaço de papel que nada significaria. (HESSE, 1991, p. 9)
} 
tentativas de municipalização do saneamento; a descentralização da política federal de habitação após a extinção do Banco Nacional de Habitação (BNH); a criação de instâncias colegiadas estaduais para a distribuição de recursos do FGTS; a municipalização das redes de ensino fundamental; os programas de municipalização da merenda escolar; a municipalização da política de assistência social, o processo de habitação municipal, o incremento do atendimento municipal no âmbito do Sistema Único de Saúde (SUS), dentre inúmeros outros exemplos. (ARRETCHE, 2000, p. 37)

Tais experiências, algumas já consolidadas como sistemas de implantação de políticas públicas, outras fracassadas, constituem, independentemente de seus efeitos, um valioso campo de testes das relações federativas, denotando que não apenas no aspecto jurídico, mas também sob o prisma político e institucional há um nítido amadurecimento das relações intergovernamentais.

Amadurecimento incompleto, tendo em vista que a concretização do federalismo cooperativo na Carta de 1988 depende, com efeito, da construção de uma cultura que congregue gradualmente, em torno dos postulados fundamentais da cooperação, a correlação de forças que comanda a atuação dos entes políticos.

A edição da Lei de Consórcios Públicos, que regulamenta o art. 241 da Constituição, é um forte indicativo de que ao menos uma cultura jurídica em prol da cooperação federal vem se consolidando no Brasil. Corroboram ainda esse posicionamento as inúmeras determinações legais relacionadas à gestão compartilhada na Lei Nacional de Saneamento. O supedâneo normativo regulamentador das disposições constitucionais é, deveras, um importante requisito para sua eficácia e para que as administrações possam buscar formas integradas de ação.

Note-se que, até este momento, ilações realizadas neste capítulo concerniram à obtenção de um quadro conceitual, histórico e institucional que permita não apenas entender os fundamentos da cooperação federal que condicionam a gestão compartilhada, com também justificar porque o compromisso de cooperação não se desenvolveu em plenitude no Brasil.

Os esforços empreendidos não se aperfeiçoarão sem que uma visão dos fundamentos econômico-gerenciais da gestão compartilhada e seus respectivos desafios no contexto federativo sejam perfilados. 


\subsection{FUNDAMENTOS ECONÔMICO-GERENCIAIS DA GESTÃO COMPARTILHADA}

No que toca ao saneamento, as causas motivadoras da prestação compartilhada são as mais variadas e envolvem questões econômicas, regulatórias, ambientais, gerenciais e administrativas.

Uma rápida enumeração das razões da gestão compartilhada corrobora o afirmado:

(i) a existência de regiões metropolitanas, aglomerações urbanas e microrregiões, o que exige, por imposição legal, uma gestão conjunta dos serviços públicos. Nesse caso, a gestão compartilhada decorre das determinações impostas por lei complementar do Estado, a ser compulsoriamente observada pelos Municípios;

(ii) a tentativa de obtenção de uma escala que ofereça sustentabilidade econômica para a prestação dos serviços, tendo em vista a baixa capacidade de financiamento das atividades pelo Poder Público local e pela população. Sistemas de subsídios cruzados e economia de escala são fatores relevantes nesse caso;

(iii) as dificuldades de acesso a corpos hídricos ou a áreas de tratamento e disposição final de resíduos, exigindo que determinados Municípios se integrem voluntariamente em busca de estrutura necessária ao desempenho do saneamento;

(iv) a adaptação da prestação de serviços de saneamento às características das bacias hidrográficas de cada região, proporcionando o uso racional e equilibrado dos recursos hídricos. Além do uso racional da água, mesmo atividades de caráter local, como o tratamento de resíduos e a drenagem, acarretam impactos em todo o sistema hídrico de uma região se geridas inadequadamente. A poluição de mananciais é muito comum em razão de aterros irregulares. A contaminação de fontes de água afeta o sistema hídrico amplamente e não apenas os mananciais de um Município isolado. Demonstrou-se, ainda, que sistemas de drenagem levam resíduos e poluição para rios que, normalmente, alcançam outras localidades. Acrescente-se, ainda que a drenagem mal desempenhada altera o ciclo hidrológico da região, uma vez que direciona volumes enormes de água para corpos hídricos que originariamente não os recebiam. Opera-se, nesses casos, uma verdadeira transposição de águas que altera o regime de vazão dos rios e, portanto, o abastecimento de 
água em toda a bacia de determinada região. Assim, não somente a interconexão entre as atividades do saneamento, como também sua influência nas comunidades limítrofes podem justificar ao menos sua regulação concatenada;

(v) as políticas de universalização dos serviços patrocinadas por entes federados de maior abrangência territorial como os Estados e a União e que têm o nítido interesse de, gradualmente, superar desigualdades regionais significativas. Nesses casos, as transferências voluntárias de recursos e infraestrutura figuram como incentivos para a regionalização dos serviços e, portanto, para a gestão compartilhada;

(vi) a padronização da regulação dos serviços em determinada região, a fim de uniformizar critérios econômicos de cobrança dos serviços, critérios ambientais de gestão, dentre outros, bem como a união de esforços entre diversos entes para reduzir os custos da regulação (compartilhamento de pessoal de fiscalização, equipamentos, etc.).

Não custa afirmar que a demonstração das motivações da gestão compartilhada não denota qualquer critério ou indicativo da titularidade dos serviços em função da abrangência regional ou local das atividades. Tal tema será tratado com a devida profundidade no capítulo 4.

$\mathrm{Na}$ enumeração acima realizada, observa-se, inicialmente, a existência de circunstâncias de gestão compartilhada obrigatória. É o caso das regiões metropolitanas, aglomerações urbanas e microrregiões.

A integração também poderá ocorrer por necessidades de insumos não encontrados no território de Município isoladamente considerado ou em razão da necessidade de obtenção da escala econômica que ofereça sustentabilidade à prestação.

Aqui o caráter regional dos serviços é, também, relevante, mas não implica, necessariamente, uma forma compulsória de gestão do saneamento, podendo dar ensejo a modelos voluntários de associação entre os entes federados (art. 241 da CF).

Mas a gestão compartilhada não se esgota no papel de integrar (compulsoriamente ou voluntariamente) as funções de interesse comum das unidades federativas.

A gestão compartilhada pode ser aplicada como instrumento de apoio na prestação dos serviços, também, nas situações em que eles poderiam ser prestados 
inteiramente no território de um único ente local. Nessas circunstâncias, é na livre vontade dos entes federados que reside a possibilidade de integração do saneamento.

Mesmo serviços com características locais, como a coleta e o transporte de resíduos, bem como a drenagem urbana (passíveis de serem prestados inteiramente em um mesmo Município), podem ser integrados à gestão compartilhada. Isso não os torna atividades de caráter intrinsecamente regional, apenas lhes confere uma gestão mais antenada com as circunstâncias ambientais ou hídricas em que se inserem.

Há, destarte, motivações para a gestão compartilhada que abrangem não apenas argumentos centrados nas implicações regionais dos serviços, mas outros benefícios, como a diluição de custos regulatórios, a disseminação de conhecimento sobre os serviços e o oferecimento de maior eficácia à gestão de serviços locais.

Para muitos, a gestão compartilhada pode ser encarada como um retrocesso visà-vis à alternativa de descentralização completa dessas atividades para os Municípios.

Em muitos casos, a descentralização pura é apresentada como mecanismo de eficiência e maior controle da ação do Poder Público, uma suposta solução para todos os problemas da gestão pública.

Com efeito, há fortes argumentos em prol da gestão puramente local tendo em vista que proporciona maior densidade democrática na gestão dos serviços (maior participação popular) e apresenta uma conexão mais óbvia com a noção de subsidiariedade que, em tese, deve reger a organização de competências no federalismo.

Tenha-se em mente, todavia, que processos extremados de descentralização de políticas e serviços públicos não são simples e nem sempre proporcionam os resultados positivos almejados, exigindo uma conformação institucional própria para sua ocorrência.

É ineficiente a atribuição de responsabilidades a entes locais que não têm condições de arcar minimamente com sua consecução. Nessa hipótese, o efeito da descentralização pode ser o oposto do pretendido. No lugar da democratização e ampliação dos serviços ter-se-ia um recrudescimento na abrangência e qualidade da prestação.

Trata-se do tipo de descentralização que normalmente predomina na América Latina: "descentralização diferenciadora, seletiva e fragmentada". (BERCOVICI; SIQUEIRA NETO, 2008, p. 60) 
Consoante destacado pelos designados autores, os resultados dessa modalidade de descentralização são o aumento das desigualdades regionais e sociais e a possibilidade de maior fragmentação nacional. (BERCOVICI; SIQUEIRA NETO, 2008, p. 60)

Arretche (2000) soube sintetizar com primazia as condições ou variáveis que influenciam o processo de descentralização de políticas e serviços públicos. Restará patente que muitas das balizas abaixo destacadas, relacionadas à gestão de políticas públicas, coincidem com as análises realizadas nos tópicos precedentes advindas da experiência evolutiva do saneamento e do federalismo brasileiro.

Os fatores determinantes da descentralização podem ser assim aglutinados: fatores do tipo estrutural; fatores do tipo institucional e fatores ligados à ação política. (ARRETCHE, 2000, p. 28)

Os fatores do tipo estrutural concernem à capacidade de realizar gastos públicos ou à capacidade político-administrativa da unidade política recebedora das atribuições. Estados e Municípios dotados de maior arrecadação e capazes de instituir condições técnicas para o desempenho do saneamento possuiriam, sob tal perspectiva, melhores condições de concretizar o saneamento. (ARRETCHE, 2000, p. 28-29)

Os fatores do tipo institucional auxiliam a compreensão da natureza das instituições nas quais são tomadas as decisões de gestão e reforma de políticas e serviços públicos. (ARRETCHE, 2000, p. 29-30)

A alargada amplitude do conceito de "instituições" impele a uma restrição de seu escopo para fins operacionais. Para Arrecthe (2000, p. 30-31), são variáveis institucionais relevantes: o legado das políticas prévias, as regras constitucionais que normatizam a prestação de bens e serviços e a engenharia operacional inerente à sua prestação.

Segundo a autora, "processos de reforma de políticas sociais são influenciados pela herança institucional de programas anteriores". Tal influência seria sentida de diversos modos. As instituições participantes das políticas passadas, muitas delas robustas e consolidadas, tendem à autopreservação, pois congregam grupos de interesses que correm o risco de ser reorganizados ou mesmo destituídos no curso das reformulações. (ARRETCHE, 2000, p. 31) 
Uma notória demonstração da tendência para autopreservação se encontra na resistência de companhias estaduais de saneamento em relação às tentativas de municipalização dos serviços.

As políticas do passado, por favorecem determinado nível de governo, criam nessa instância uma capacidade técnica inexistente ou diferenciada daquela encontrável nas demais esferas federativas originariamente excluídas do processo decisório e de execução dos serviços. Recursos humanos, instrumentos técnicos, infraestrutura, capacidade legal e outros se encontram concentrados em poucas esferas, dificultando e tornando custoso o processo de descentralização para unidades desprovidas desses meios. Trata-se do fenômeno da policy preemption (designação dada pela ciência política norte-americana), típico de arranjos federativos, em que "o espaço político ocupado por um nível de governo limita a margem de ação dos demais”. (ARRETCHE, 2000, p. 31)

No caso do saneamento, a concentração de recursos em nível federal e nas empresas estaduais, detentoras de recursos técnicos e humanos, é um demonstrativo inequívoco da policy preemption.

A forte influência de desenhos institucionais anteriores se vê também na limitação que provoca no quadro conceitual necessário à identificação de problemas e à proposição de soluções em cada tipo de política ou serviço (ARRETCHE, 2000, p. 31). Assim é que, no saneamento, os subsídios cruzados figuram como alternativa para a sustentabilidade econômica dos serviços, caracterizando-se, ainda hoje, como uma prática corriqueira nos modelos de prestação dos serviços, em detrimento do aprimoramento das condições de operação dos sistemas. Os métodos e abordagens de gestão se perpetuam quase que por inércia, a não ser que novas posturas administrativas adquiram espaço na mentalidade dominante dos agentes tomadores de decisão.

Quanto às normas constitucionais que cuidam da prestação dos serviços, a forma como distribuem as competências entre as esferas de governo pode incentivar ou dificultar processos de descentralização. (ARRETCHE, 2000, p. 31)

As determinações constitucionais a respeito do saneamento dão margem, conforme demonstrado adiante, a interpretações discrepantes a respeito da titularidade dos serviços. A dimensão normativa não oferece, sob tal aspecto, incentivos consistentes para a descentralização, contribuindo para divergências sobre o tema. 
A última variável institucional a ser detalhada, a engenharia operacional própria da prestação, diz respeito às características inerentes de cada política pública que tornam sua implantação um desafio específico, a demandar capacidades e recursos adaptados. (ARRETCHE, 2000, p. 32)

Demonstrou-se, no capítulo 2 deste trabalho, que um item relevante da engenharia operacional do saneamento básico, em especial dos serviços de água e esgoto, consiste na necessidade de elevados investimentos iniciais para a instalação das redes. Esse fator impede que esferas de governo com menor capacidade de investimento possam assumir com primazia suas funções de aprimoramento e expansão de infraestrutura.

Os fatores ligados à ação política englobam a relação entre Estado e sociedade e entre os distintos níveis de governo. Segundo essa visão, o sucesso dos modelos de descentralização são mais consistentes nos governos locais em que se constata uma cultura cívica significativa incentivando a participação democrática na condução dos rumos públicos. Trata-se de da construção de um "capital social" pronto a assumir a responsabilidade das novas funções recebidas. (ARRETCHE, 2000, p. 33)

De outro lado, a existência de uma efetiva ação de apoio dos entes federados mais abrangentes em favor das unidades locais pode significar o principal fator de sucesso na transferência de funções.

Os problemas administrativos e financeiros dos governos subnacionais dificultam a desconcentração de funções. Isso torna o apoio de entes de maior abrangência e poderio um fator de peso na condução de processos desse gênero, a oportunizar subsídios técnicos, financeiros e uma coordenação mínima de esforços.

Não se situa entre as metas do trabalho a exaltação absoluta da gestão compartilhada como mecanismo gerencial ou administrativo para prestação de serviços de saneamento. Situações haverá em que a prestação local, restrita ao ente titular originário da competência, será viável e até mesmo aconselhável.

Ocorre que, diante de todas as variáveis destacadas, propugna-se pela ideia de que a gestão compartilhada, em médio e longo prazos, pode, ao lado da evolução tecnológica, fortalecer o conhecimento técnico e econômico a respeito da prestado dos serviços públicos, consolidando centros de excelência que poderão evoluir até mesmo para a gestão exclusivamente municipal do saneamento. 
Entre os extremos da centralização e descentralização absolutas pairam figuras intermediárias, cujo fundamento reside na relação interfederativa e no apoio mútuo, e não nas simples avocação ou delegação de competências.

Frise-se que embora o federalismo seja, inegavelmente, um sistema de repartição de competências que ora se apresentará mais centralizado, ora tenderá para a descentralização, a depender das vicissitudes históricas e da cultura política de cada Estado, sua verdadeira força reside na possibilidade de conjugação matricial de responsabilidades, organizadas em um complexo arranjo de interferências recíprocas.

Assim, o debate entre centralização e descentralização mostra-se um tanto estéril e vazio. A pura descentralização apresenta elevados riscos e a cooperação intergovernamental adquire papel preponderante na construção de um federalismo eficiente.

\subsection{CONCLUSÕES PRELIMINARES}

A rápida digressão a respeito da evolução da cooperação federal no Estado brasileiro demonstrou como a natureza e as dimensões do federalismo encontram-se fortemente influenciados pela construção das instituições políticas e ainda pela maneira como o Estado promove o desenvolvimento socioeconômico. (SADDI, 1999, p. 20)

O fato é que as relações entre o amadurecimento político e o desenvolvimento de uma sociedade verdadeiramente federal apresentam condicionantes próprios em países com a história semelhante à do Brasil.

Conforme nos informa Fabiana Saddi (1999, p. 22), em países como os "Estados Unidos, por exemplo, a questão volta-se não para a criação de autoridade e o acumulo de poder, mas de preferência para a limitação da autoridade e divisão de poder”.

Já no contexto brasileiro, a questão encontra-se focada na constante necessidade de construir novas bases de autoridade legítima para o Estado (constantemente alteradas pelas vicissitudes políticas), o que faz qualquer desejo de fortalecimento da cooperação em um federalismo tradicionalmente incompleto perder estabilidade e força. $\mathrm{O}$ resultado é um sistema federal que não resulta na autonomia e no relacionamento 
cooperativo das unidades subnacionais, mas na dependência dessas em relação ao Poder Central. (SADDI, 1999, p. 22)

Um agravante reside na circunstância de que, com exceção do contexto político de 1946 e com a redemocratização da década de 1980, o Brasil pouco ofereceu em termos de um regime democrático sólido que possibilitasse um federalismo cooperativo paupável e duradouro. Tratava-se, assim, de uma predisposição política para a centralização calcada nos regimes autoritários que marcaram a evolução da administração brasileira. ${ }^{72}$

A estratégia de desenvolvimento econômico dominante no ideário dos governantes brasileiros durante parte considerável do século XX também favoreceu a conformação centrípeta do nosso federalismo (tem-se em mente a doutrina do desenvolvimentismo e suas diversas vertentes).

O relevante papel do Estado na industrialização e prestação de serviços essenciais atraiu naturalmente para a unidade federativa detentora de maiores recursos econômicos (a União) o desempenho de tarefas relacionadas ao desenvolvimento de infraestrutura e outros setores cruciais para o país.

Aproximando tal discussão do saneamento, a descrição empreendida confirmou a estreita evolução histórica dos serviços com o desenvolvimento do Estado Federal. Nesse sentido, como já afirmado neste trabalho, a experiência histórica do saneamento é um retrato fidedigno da dinâmica do Estado Federal brasileiro, em que a União em primeiro lugar e, posteriormente, os Estados, por deterem o controle da maior parte das receitas públicas, acabam retendo uma elevada ingerência nas políticas públicas de interesse local.

A história do saneamento, descrita no capítulo 1, prova que sua prestação ocorreu, fundamentalmente, com base nas diretrizes da União e, já na fase do Planasa, em infraestrutura controlada por entidades estaduais conforme determinações federais. Ou

\footnotetext{
${ }^{72}$ Curioso notar como a evolução do federalismo brasileiro contraria as predições de Hamilton (1959, p. 190191) sobre a natureza dos regimes federativos. Para a citada figura histórica, a tendência dos esquemas federativos seria presenciar o gradual enfraquecimento do governo federal: "Vimos em todos os exemplos das confederações antigas e modernas, que a tendência mais potente que continuamente se manifesta nos membros, é a de privar o governo federal de suas faculdades, tanto que este revela mui pouca capacidade para defender-se contra estas exorbitâncias. [...] Os governos dos Estados terão sempre a vantagem sobre o governo federal, seja que os comparemos do ponto de vista da dependência imediata de um para com outro, do peso da influência pessoal que cada lado possuirá, dos poderes respectivamente outorgados a eles, da predileção e o provável apoio do povo, da inclinação e faculdade para resistir ou frustrar as medidas do outro."
} 
seja, da perspectiva dos Municípios, houve, com poucas exceções, centralização do controle dos serviços ora na União, ora nesta em conjunto com os Estados.

Apesar de questões de ordem prática intransponíveis, como o tamanho reduzido de muitos Municípios, dotados de baixa capacidade de arrecadação e investimento, é forçoso admitir que o atual estágio da gestão do saneamento no Brasil é fruto, ao menos em parte, de uma postura centralizadora que impediu que a maioria dos entes municipais desenvolvessem as capacidades necessárias para a assunção dos serviços.

Destaque-se que o Planasa teve não somente o mérito de expandir consideravelmente os serviços, bem como de envolver os Estados na sua gestão, atingindo um nível de descentralização maior que o de muitas políticas públicas da época. Mesmo com a inclusão dos Estados (por meio das empresas estaduais de saneamento), a dependência dos financiamentos da União e a subordinação às diretrizes gerais por ela definidas é um fato incontestável.

Daí se afirmar que o percurso histórico do saneamento é produto de influências particulares e próprias do setor, como viso acima, mas é também reflexo da evolução do federalismo brasileiro. O mesmo federalismo que, com a Constituição de 1988, inaugurou novas possibilidades de relação institucional no Estado brasileiro, tornando mais concreta a alternativa da gestão compartilhada.

Por certo que a evolução do federalismo de cooperação no Brasil não deve ser encarada como uma história de puro fracasso. Muito se desenvolveu no país no que toca à aproximação dos entes federativos, fato potencializado com o processo de democratização política e pela predisposição de muitos governos em empreender uma gestão mais descentralizada das questões públicas.

O processo de amadurecimento das relações intergovernamentais aponta para um aprimoramento dos mecanismos de cooperação federal, de forma a superar a dicotomia estéril entre centralização e descentralização, uma dualidade que pouco acrescenta ao debate e à definição de novas formas de organização de serviços públicos, o que leva esta discussão diretamente ao exame da gestão compartilhada dos serviços de saneamento e seus aspectos institucionais. 


\section{A GESTÃO COMPARTILHADA DO SANEAMENTO SOB O ASPECTO INSTITUCIONAL}

As finalidades previstas nas normas jurídicas não se realizam espontaneamente. Demandam, para sua realização, a ação de instituições e a distribuição de responsabilidades e competências entre atores sociais. Neste capítulo, o objetivo é justamente avaliar o desenho institucional no âmbito da gestão compartilhada.

Alguns esclarecimentos metodológicos auxiliaram a traçar os limites materiais utilizados para a descrição do arcabouço institucional visado.

Tem-se por premissa, consoante descrito nos capítulos precedentes, que a gestão compartilhada do saneamento é formada pela aplicação de institutos capazes de relacionar em torno da prestação dos serviços dois ou mais entes federados. Nesse sentido, a gestão associada de serviços públicos e as regiões metropolitanas figuram como relevantes subsídios para análise.

Todavia, o objeto de estudo deste capítulo não reside puramente no deslinde da natureza e das características dos consórcios, convênios de cooperação e regiões metropolitanas, aglomerações urbanas e microrregiões, mas nas relações e possibilidades que proporcionam quando aplicados na concretização dos serviços de saneamento básico.

A consequência principal desse "corte metodológico" consistirá no direcionamento dos esforços investigativos para a interface entre o saneamento e os institutos acima descritos, e não no seu exame isolado ou autônomo, afastando-se o risco de desvios na linha adotada neste trabalho.

Nesse contexto, a natureza e as características jurídicas dos consórcios, convênios de cooperação e região metropolitanas serão utilizados como dados acessórios para o estudo do saneamento, e não como foco principal de análise. 


\subsection{ORGANIZAÇÃO DAS COMPETÊNCIAS A RESPEITO DO SANEAMENTO E SEU IMPACTO NA GESTÃO COMPARTILHADA}

A repartição de competências é o cerne do funcionamento dos Estados Federados, consistindo, também, no primeiro pilar a ser assentado para a descrição institucional da gestão compartilhada do saneamento, uma vez que esta pressupõe delegação e conjugação de atribuições constitucionais.

A repartição de competências evoluiu de modelos dualistas, como o verificado na formação dos Estados Unidos e na Constituição brasileira de 1891, até sistemas mais complexos como o presente nas Constituições da Áustria de 1920, da Alemanha de 1949 e da Índia de 1950, com o destaque da Lei Fundamental de 1949, que contemplou os Estados Membros - os Länder - com significativa matéria legislativa. (HORTA, 1999, p. 15)

A Constituição de 1988 seguiu as tendências contemporâneas de repartição de competências no Direito Constitucional, prevendo competências materiais privativas da União (art. 21); competências legislativas privativas da União (art. 22); competências materiais comuns da União, Estados, Distrito Federal e Municípios (art. 23); competências legislativas concorrentes entre União, Estados e Distrito Federal (art. 24); competências residuais dos Estados (art. 25, § $1^{\circ}$ ); competência dos Municípios para legislar sobre assuntos de interesse local, para suplementar a legislação federal e estadual no que couber e para organizar e prestar os serviços públicos de interesse local (art. 30, I, II e V).

Estabelecido o referido arranjo competencial, previsível que a realização concreta dos ditames constitucionais provoque dúvidas, disputas e considerações críticas. Tenha-se como exemplo o conceito de interesse local e, portanto, o fato de que o entendimento do que pertine ou não ao Município, do ponto de vista material e legislativo, delimita não somente o âmbito de atuação municipal, como também, reflexamente, as competências do Estado, pois em sua maioria residuais (art. $25, \S 1^{\circ}$, da CF).

A dinâmica federal se processa em um complexo jogo de interferências recíprocas que, naturalmente, ocasiona zonas de contato ou áreas cinzentas, fator potencializado pela utilização de noções abertas e imprecisas como "diretrizes", "normas gerais" e "interesse local" como critérios para o estabelecimento de responsabilidades e capacidades. 
Assim tem sido a respeito do saneamento, tanto no que se refere ao desempenho de competências materiais quanto ao exercício de competências legislativas, constatação que motiva os tópicos seguintes deste capítulo.

\subsubsection{O desafio da delimitação da titularidade do saneamento: estabelecendo as linhas de compreensão do problema}

A par de possuir indiscutível importância para o interesse local e, portanto, para os entes municipais, o saneamento pode, com facilidade, adquirir elevada relevância regional e, em última instância, sempre constará como preocupação de peso no quadro de prioridades de um governo de índole nacional.

Em outras palavras, à Federação interessa a prestação dos serviços de saneamento básico, diante de seu considerável papel na otimização dos padrões sociais de vida, sobretudo aqueles relacionados à saúde pública.

Se é inegável que o comando previsto no art.30, V, da Constituição nos dá forte indicativo quanto à titularidade municipal do saneamento básico, é preciso reconhecer a existência de situações outras em que o interesse sobre uma satisfatória prestação de serviços será comum às três esferas federativas.

O esclarecimento da titularidade dos serviços nessas circunstâncias é condição para a existência de segurança jurídica no setor, requisito fundamental para a realização de novos investimentos e expansão da rede.

As indeterminações a respeito da titularidade do saneamento derivam certamente da profusão de normas constitucionais que tratam das competências para sua prestação e regulação.

Por ora, será dado destaque às competências materiais a respeito do saneamento. Ao final, a conclusão obtida a respeito da titularidade dessas competências materiais auxiliará no entendimento do exercício de competências legislativas no setor, tema que impõe considerações apartadas em função das múltiplas ilações que provoca.

A respeito das competências materiais, avalie-se o disposto no art. 23 da Carta de 1988: "É competência comum da União, dos Estados, do Distrito Federal e dos 
Municípios: [...] IX - promover programas de construção de moradias e a melhoria das condições habitacionais e de saneamento básico;" Não se deve esquecer, ainda, do que determina o inciso III do art. 200, segundo o qual compete ao Sistema Único de Saúde "participar da formulação da política e da execução das ações de saneamento básico".

$\mathrm{O}$ art. 30 da Constituição informa que compete aos Municípios: "V - organizar e prestar, diretamente ou sob regime de concessão ou permissão, os serviços públicos de interesse local, incluído o de transporte coletivo, que tem caráter essencial".

Já aos Estados cabe a instituição de região metropolitana por meio de lei complementar (art. 25, § $3^{\circ}$ ), para integrar a organização, o planejamento e a execução de funções públicas de interesse comum em Municípios limítrofes.

Em regra, os serviços de saneamento são considerados de interesse local e, portanto, pertinentes à esfera de competência material dos Municípios (art. 30, V).

Ninguém dúvida que serviços prestados totalmente no território de um único Município integram a sua respectiva competência.

Os autores se digladiam quando entra em jogo a condução de serviços com impacto ou abrangência regional, refletida na região metropolitana instituída por lei estadual ou em circunstâncias de fato que impelem a prestação interdependente do saneamento em dois ou mais Municípios. São encontradas, nesses casos:

(i) posições que defendem a titularidade municipal em qualquer circunstância, mesmo quando da constituição de região metropolitana;

(ii) posições que defendem a titularidade do Estado-Membro quando envolvidos dois ou mais Municípios integrantes de seu território, especialmente no caso das regiões metropolitanas;

(iii) posições intermediárias que enxergam uma titularidade conjunta de Estados e Municípios e, em alguns casos, também da União, quando o interesse em jogo apresentar caráter nacional.

Embora parte considerável das decisões de tribunais e opiniões abaixo divulgadas digam respeito à prestação dos serviços nas regiões metropolitanas, pretende-se a individualização de um sistema claro de titularidade aplicável a toda e qualquer hipótese em que um interesse regional se verifique no desenvolvimento do saneamento básico, a 
abranger também as hipóteses de associação voluntária como consórcios públicos e convênios de cooperação.

Isso, em razão da imprescindibilidade de critérios homogêneos e uniformes para delimitação da titularidade, sob pena de prejuízo à segurança jurídica. Seria inviável a definição de critérios de titularidade que não fossem apreensíveis como regras gerais e abstratas derivadas do corpo constitucional.

Destaque-se que muitos doutrinadores de peso já se posicionaram sobre o assunto. A seguir fez-se uma exposição sintética dessas opiniões e, ao final, a opção por aquela que, entende-se, melhor se adapta ao regime jurídico do saneamento e da própria gestão compartilhada.

\subsubsection{Posições em prol da titularidade municipal}

Como colocado, muitos autores manifestaram opiniões sobre a titularidade dos serviços de saneamento. Daí a exposição desses entendimentos doutrinários e das decisões jurisprudenciais que os respaldam.

Marques Neto (2005c, p. 134) restringe o âmbito da controvérsia em torno da titularidade. Exclui da discussão os serviços de limpeza urbana e de drenagem, por reputálos essencialmente locais e, portanto, pertinentes à competência municipal, centrando suas atenções nos serviços relacionados ao abastecimento de água e ao esgotamento sanitário.

Encara atividades de distribuição de água e coleta de esgotos (faceta dos serviços onde se verifica o contato direto com os usuários) como locais, enquanto a captação e a adução de água, bem como algumas etapas intermediárias da cadeia de serviços (coleção e distribuição no atacado e tratamento de água bruta), por dependerem das características hidrológicas da região e da forma como ocorre o uso e a ocupação do solo, poderiam assumir caráter local ou não. (MARQUES NETO, 2005c, p. 135-136)

A despeito da possibilidade de prestação regional de algumas das etapas da cadeia dos serviços de água e esgoto, entende o autor que seria adequado considerá-los como de caráter local, já que são essencialmente locais as etapas ligadas diretamente aos usuários (distribuição de água e coleta de esgoto) e que consubstanciam ou representam a 
função pública dos serviços - pois proveem a utilidade essencial aos cidadãos. (MARQUES NETO, 2005c, p. 137)

Em síntese, ainda que as etapas conformadoras da função pública do saneamento dependam ocasionalmente de insumos de caráter regional, situados em outro Município, isso não desvirtua seu caráter local. Nesses casos, o que existiria seria não a mudança da titularidade dos serviços, mas a necessidade de implicação dos demais entes federados na sua organização. (MARQUES NETO, 2005c, p. 138)

Tudo isso porque a titularidade, como categoria jurídica, é abstrata, não poderia depender das circunstâncias concretas da infraestrutura que serve de suporte ao saneamento, sob pena de elevada instabilidade regulatória. Do contrário, sempre que os serviços fossem reorganizados ou reestruturados, haveria o risco de mudança do titular conforme a abrangência da reorganização adotada. (MARQUES NETO, 2005c, p. 138)

Não seria defensável na opinião de Marques Neto (2005c, p. 139) sustentar a transferência de titularidade ao Estado em razão do disposto no art. 23, IX, da Constituição (melhoria das condições de saneamento como competência material comum das unidades federadas), uma vez que a norma tem caráter incitativo, concerne à atuação coordenada e cooperativa na implantação de utilidade pública essencial e não indica a possibilidade de avocação de competências materiais dos Municípios.

Ademais, segundo o autor, atribuir a todos os entes a tarefa de prestar o saneamento seria flagrantemente ineficiente em virtude do desperdício de recursos que acarretaria. Destarte, o dispositivo constitucional em referência (art. 23, IX) somente faz sentido se interpretado em conjunto com as demais normas que disciplinam a distribuição de competências federativas de caráter material. (MARQUES NETO, 2005c, p. 139)

De igual modo, o autor posiciona-se contrariamente à possibilidade de que lei complementar estadual criadora da região metropolitana possa alterar o desenho de competências no saneamento. Isso porque a autonomia municipal é garantida nos arts. 29, 30 e 31 da Constituição e não pode ser modificada com base na vontade única do Estado. Tenha-se como paralelo a regra do parágrafo único do art. 22 que possibilita à União delegar aos Estados por meio de lei complementar competências legislativas privativas. Nesse caso, a transferência de competências se mostra viável por se tratar de delegação e não avocação de competências, ou seja, o ente detentor da prerrogativa espontaneamente a concede aos Estados. (MARQUES NETO, 2005c, p. 139) 
Nesse contexto, a regra do art. 25, $\S 3^{\circ}$, da Constituição, para Marques Neto (2005c, p. 141), faz com que nova dimensão regional seja acrescida à local (e não substituída): "obriga a que os Municípios, ao exercerem suas competências locais - que permanecem intocadas - coordenem seus esforços de maneira integrada e tenham em conta o fenômeno regional". Os Municípios incluídos na região metropolitana são obrigados a obedecer aos parâmetros regionais, o que denota que a área metropolitana passa a ser um critério para a coordenação e cooperação federal entre Municípios e Estados. A realização concreta de um poder-dever do Estado, que deve zelar para que os aspectos regionais sejam observados por todos os entes municiais no exercício de suas competências locais.

A posição de Marques é muito próxima da manifestada por alguns ministros do Supremo Tribunal Federal em ações diretas de inconstitucionalidade cujo objeto são leis complementares estaduais que, ao instituir regiões metropolitanas, transferem ao Estado competências relativas à regulação e prestação dos serviços de saneamento.

É o caso da ADI n. 1.842-5, que tem por objeto o exame da inconstitucionalidade da Lei Complementar n. 87/97, do Estado do Rio de Janeiro (institui a Região Metropolitana do Rio de Janeiro). A lei em questão definiu os serviços regionais de saneamento como serviços públicos de interesse comum dessa região metropolitana, atribuindo ao Estado a competência para sua regulação e prestação.

$\mathrm{O}$ voto do então Ministro Nelson Jobim apontou, na hipótese, a competência municipal dos serviços, mesmo sob a vigência da região metropolitana.

Para o Ministro, as regiões metropolitanas foram criadas como mecanismo que viabiliza, de maneira racional e econômica, a prestação de serviços de natureza comum, cuja execução abarque o interesse de mais de um Município. Expõe Jobim que a região metropolitana não se constitui em quarto nível da federação brasileira e nem possui autonomia que possa ser exercida à revelia dos interesses dos Municípios envolvidos.

Em reforço a essa concepção, destaca o magistrado o caráter administrativo das regiões metropolitanas, a consistir em mero órgão de gestão, ausente qualquer função política ou personalidade de direito público que possa colocá-las como figura intermediária entre Estado e Municípios.

Ainda nos termos do voto proferido por Jobim, se de um lado a titularidade das funções continua a ser municipal, nas regiões metropolitanas seu exercício só é possível em consenso com os demais Municípios integrantes: "Por isso, é de se reconhecer um 
vínculo, não de subordinação, mas de cooperação no processo decisório interno a formar um ente do "Federalismo de Cooperação".

O interesse regional, substrato metropolitano, corresponde à soma integrada dos interesses dos Municípios envolvidos: "o interesse regional é o conjunto articulado e consensual dos interesses municipais em jogo".

Como consequência, para Jobim, o Estado não decide políticas administrativas regionais, não tem o poder de legislar em questão de interesse comum dos Municípios, tampouco pode se atribuir competências ou atribuições exclusivas da autonomia municipal.

É de se questionar qual seria o papel do Estado nesse contexto. O Estado detém uma competência procedimental e não material. Deve cuidar da instituição da região metropolitana no exercício do que o magistrado denomina de "reserva legal qualificada".

Vale dizer, a competência insculpida no $\S 3^{\circ}$ do art. 25 da Constituição somente será exercida em razão de um imperativo: integrar (aqui em um sentido procedimental) a organização, o planejamento e a execução de funções públicas de interesse comum pelos Municípios. Em outras palavras, cabe ao Estado somente instituir o agrupamento municipal e delimitar a forma e os procedimentos a serem observados para a sua decisão consensual e integrada a respeito do exercício das funções de interesse comum.

Justamente para evitar abusos, a integração metropolitana não deflui da simples vontade do Estado. Deve corresponder à necessidade concreta de integração para solução de problemas comuns, e não a mera ficção jurídica criada pela lei complementar. Esta apenas reconhece a imprescindibilidade da integração dos Municípios já assentada nos pressupostos verificáveis na dinâmica do agrupamento municipal.

O Ministro Eros Roberto Grau defende igualmente a titularidade municipal dos serviços de saneamento (nesse sentido seu voto na ADI n. 2.077, que avalia a constitucionalidade de disposições da Constituição do Estado da Bahia).

Para o Ministro, o serviço público de fornecimento de água e coleta e destinação final de esgotos, em regra, é atribuído à competência municipal em face da predominância do interesse local que o afeta. Segundo o magistrado, é mais do que assente na doutrina que o interesse que fundamenta a competência dos Municípios é aquele predominantemente (e não exclusivamente) local, ou seja, o interesse que predomina quando confrontado com os interesses do Estado-Membro e da União. Do caráter interlocal 
que permeia os serviços comuns em regiões metropolitanas exsurge a necessidade de uma administração intermunicipal e não estadual.

Completa o Ministro com a afirmação de que o preceito inscrito no $\S 3^{\circ}$ do art. 25 do Texto Constitucional nada faz em termos de transferir competências aos Estados, apenas refere à instituição de regiões metropolitanas, aglomerações urbanas e microrregiões, tendo em vista a integração da organização, do planejamento e da execução de serviços comuns e, "nisso e com isso, limita as atribuições, do Estado-membro, que poderiam decorrer do exercício daquela competência":

\begin{abstract}
A norma destacada do texto constitucional é o modelo de 'como as coisas devem ser' relativamente à competência para a organização e prestação dos serviços públicos 'metropolitanos', objeto de demanda social no espaço de Municípios conurbados: o interesse local, no caso, se desdobra em interesse interlocal; a competência para organizá-los e prestá-los seria municipal. Esse modelo será completado pela norma destacada do preceito inscrito no $\S 3^{\circ}$ do artigo 25 do texto constitucional: ainda que a competência para a organização e prestação desses serviços seja dos Municípios afetados pelo interesse interlocal, o Estadomembro poderá [deverá, mesmo] - desde que, no caso, institua, mediante lei complementar, região metropolitana - prover no sentido da integração da organização [inclusive planejamento] e execução deles; mas poderá [deverá] apenas isso.

Por isso mesmo essa atuação, do Estado-membro, no sentido de prover aquela integração, não compromete a integridade das competências constitucionalmente atribuídas aos Municípios. Em outros termos: a competência para organizar e prestar aqueles serviços será dos Municípios, aos quais incumbirá atuação integrada, provida pelo Estado-membro; nem por isso, no entanto, deixa de se manifestar como competência municipal. (STF ADI n. 2.077)
\end{abstract}

Enfim, para Eros Grau, cabe ao Estado-Membro - desde que, no caso, institua, mediante lei complementar, região metropolitana - prover somente no sentido da integração da organização (inclusive planejamento) e execução dos serviços comuns.

A atuação do Estado-Membro para prover a integração não compromete a solidez das competências constitucionalmente atribuídas aos Municípios.

Convém mencionar, ainda, a posição de Porto Neto (2005, p. 81), para quem o fato de o Município integrar região metropolitana, aglomeração urbana, microrregião (instituída por lei complementar federal) não altera sua competência em relação à execução dos serviços que, "apesar disso, passa a se subordinar à regulação e ao planejamento regional e às normas de organização compartilhada, nos termos definidos em lei complementar". Destaca Porto Neto (p. 81) que não seria adequado com o princípio da Federação e com o da autonomia dos entes que a integram sustentar que o Estado, por 
decisão própria e exclusiva, possa absorver competências que a Constituição Federal confere aos Municípios.

Importante ponderar que, por razões de ordem lógica, presumindo-se como corretas as razões dos autores e votos judiciais citados neste tópico, suas conclusões a respeito da preponderância da competência municipal podem ser facilmente estendíveis a toda e qualquer situação em que presente um interesse regional no saneamento, mesmo que derivado de circunstâncias fáticas outras, não ensejadoras da criação de região metropolitana, como no caso de associação voluntária das unidades federadas - gestão associada do art. 241 da Constituição.

Deveras, se são válidas tais conclusões para as regiões metropolitanas, que simbolizam medida de observância compulsória pelos Municípios, tanto mais o serão para hipótese de gestão compartilhada em que não há obrigatoriedade, antes voluntariedade, como substrato do exercício comum de serviços.

\subsubsection{As posições que defendem a relativização da titularidade municipal em favor do Estado}

Muitas são os posicionamentos que optam pela relativização da titularidade municipal em favor dos Estados, seja no caso das regiões metropolitanas, seja nas hipóteses em que um interesse regional nos serviços se verifique independentemente do fenômeno metropolitano (e figuras afins como a aglomeração urbana e a microrregião).

Para Barroso (2002, p. 14), o reconhecimento da competência do Estado para desempenhar os serviços de interesse comum, particularmente no âmbito das regiões metropolitanas, aglomerações urbanas e microrregiões, "decorre de uma imposição do interesse público, no que diz respeito à eficiência e qualidade do serviço prestado e, muitas vezes, até mesmo à sua própria possibilidade".

Segundo o autor, assunção pelo Estado das competências para os serviços comuns não representa restrição indevida da autonomia municipal, já que esta é definida pelo Texto Constitucional: o mesmo texto que confere aos Municípios competência para os 
serviços de interesse local é o que possibilita a existência de regiões metropolitanas e define papel dos Estados nesse particular (p. 15).

O Ministro Maurício Corrêa, relator da ADI n. 1.842-5, em seu voto, reconhece aos Estados a prerrogativa para prestar e regular os serviços no ambiente regulatório. Com efeito, declarou como constitucionais diversos dispositivos da Lei Complementar n. 87/89 e de leis ordinárias que atribuíam ao Estado do Rio de Janeiro a competência para executar os serviços e legislar sobre a política tarifária:

\begin{abstract}
Por outro lado, a regionalização de municípios limítrofes, devidamente justificada, longe está de caracterizar intervenção do Estado ou mesmo usurpação de autonomia e competência municipal, antes materializa compartilhamento de atribuições e serviços públicos sob a direção executiva do Estado, em face do seu caráter regional, o que encontra expressa autorização no ordenamento constitucional vigente.

$[\ldots]$.

Verificado o interesse geral regional predominante na utilização racional das águas, pertencentes formalmente ao Estado, o que o torna gestor natural de seu uso coletivo, assim como da política de saneamento básico cujo elemento primário é também a água, resta claro competir ao Estado-membro, com prioridade sobre o Município, legislar acerca da política tarifária aplicável ao serviço público de interesse comum. (STF ADI n. 1.842-5)
\end{abstract}

A despeito de afirmar claramente a possibilidade de transferência para Estados de competências municipais em decorrência da constituição de região metropolitana, o Ministro Maurício Corrêa, em seu voto, aponta em muitos trechos a importância da participação dos Municípios no processo de tomada de decisões. Mostra-se ambíguo nesse ponto, uma vez que encara a integração decisória dos Municípios como um importante requisito para o funcionamento do fenômeno metropolitano:

Sem dúvida, a instituição desse mecanismo torna relativa a autonomia municipal nas matérias que a lei complementar julgou por bem transpor para o Estado, porém a participação dos Municípios na solução dessas questões não é apenas desejável, segundo o espírito democrático que deve nortear tal atuação, mas essencial, em face da qualificação do próprio sentido do verbo integrar utilizado pela Constituição, do qual desponta cristalino que as decisões de interesse dessas áreas deverão ser compartilhadas entre os Municípios que o compõe e o Estado.

\title{
$[\ldots]$.
}

Não é razoável pretender-se que, instituídos esses organismos, os Municípios que os compõem continuem a exercer isoladamente as competências que lhes foram cometidas em princípio, uma vez que nessas circunstâncias estabelece-se uma comunhão superior de interesses, daí porque a autonomia a eles reservada 
sofre naturais limitações oriundas do próprio destino dos conglomerados de que façam parte.

$[\ldots]$.

Nessas situações, o interesse público muitas vezes prepondera, exigindo uma atuação conjunta, organizada, dirigida e planejada por terceira entidade, no caso o Estado, ao qual estão vinculados os Municípios.

$[\ldots]$.

Dizem a razão e bom sendo que toda a definição acerca do assunto seja disciplinada pelo Estado em conjunto com os Municípios e não mais por estes isoladamente. (STF ADI n. 1.842-5)

Vê-se que o referido voto encontra-se a meio caminho do entendimento que propugna pela partilha da titularidade entre Estados e Municípios, embora defenda ser possível que apenas o Estado desempenhe a execução de funções de interesse comum.

Um dos mais notórios defensores da titularidade estadual dos serviços de interesse comum é Tácito (2000). Comunga o autor a respeito da preponderância do interesse regional sobre o local e de que a avocação de competências pelo Estado não simboliza restrição à autonomia municipal:

A lei complementar estadual, instituidora da região metropolitana, afirma a
intima correlação de interesses que, em benefício do princípio da continuidade,
da produtividade e da eficiência, torna unitária e coordenada, em entidade
própria do Estado, segundo a lei complementar, a gestão de serviços e atividades
originariamente adstritos à administração local.

A avocação estadual de matéria ordinariamente municipal não viola a autonomia do Município na medida em que se fundamenta em norma constitucional, ou seja, em norma de igual hierarquia. É a própria Constituição que, ao mesmo tempo, afirma e limita a autonomia municipal. (TÁCITO, 2000, p. 307)

Tácito (2000) insere como causa motivadora da competência estadual não somente a existência de região metropolitana, mas, também, os mecanismos consensuais de gestão associada de serviços públicos, bem como as situações fáticas em que materialmente se verifica um serviço que ultrapasse o interesse de um único Município.

Com isso confere uma abrangência consideravelmente maior à competência estadual, visto que essa se faz presente independentemente da região metropolitana, bastando para sua consolidação a existência de um serviço de interesse comum.

A reserva de competência municipal para serviços de saneamento básico pressupõe, para o autor, que as todas as suas fases se realizem inteiramente na área 
municipal. Ultrapassados tais limites, cabe ao Estado sua regulação e administração, pois prepondera o interesse comum sobre o peculiar interesse local:

De todo o exposto decorrem, quanto à substância da consulta premissas essenciais:

a) nos Municípios incluídos na Região Metropolitana, os serviços de saneamento básico são, em sua totalidade, de competência estadual plena, conforme regulado em legislação específica;

b) a reunião dos Municípios em aglomerados urbanos ou microrregiões atenderá às normas específicas na respectiva Lei Complementar (art. 25, $\S 3^{\circ}$ da Constituição);

c) mediante convênio de cooperação, nos termos do art. 241, como regido pela Emenda Constitucional n. 19/98, caberá a gestão associada dos serviços;

d) acresce mais que, mesmo nos Municípios não abrangidos nas hipóteses das alíneas acima, o princípio da indispensável continuidade dos serviços de saneamento básico, a partir de suas origens até sua disponibilidade pelos usuários, poderá colocar em plano dominante a competência estadual, cabendo, ademais, a estipulação de convênio de cooperação que venha a ser pactuado entre Estado e município (Emenda Constitucional n. 19/98).

Em síntese, a excepcional reserva de competência municipal para serviços de saneamento básico pressupõe que, em todas as suas fases (da captação até o consumo de água, de que é complementar a coleta e tratamento de esgoto) ele se realizam, por inteiro, na área municipal.

$\mathrm{Na}$ medida em que ultrapassa tais limites, cabe ao Estado sua regulação e administração, em conformidade com a supremacia do interesse comum sobre o do peculiar interesse local. (TÁCITO, 2000, p. 309) ${ }^{73}$

Apresentados os principais argumentos que defendem a titularidade do Estado, são discutidas, em seguida, as opiniões que orbitam em torno da titularidade do saneamento compartilhada por Estados e Municípios.

\subsubsection{As posições intermediárias: a titularidade conjugada de Estados e Municípios}

Constata-se a existência de opiniões que defendem uma titularidade conjugada de Estados e Municípios a respeito das funções e interesses comuns prestados na região metropolitana.

${ }^{73}$ São ainda partidários da competência estadual no caso de regiões metropolitanas os seguintes autores: Ataliba e Roselea Folgosi (1995), Tanaka (2005) e Pires (1987). 
Uma das principais manifestações dessa vertente reside no magistério de Alves (1999, p. 62), para quem a criação de região metropolitana induz ao entendimento de que a as funções de interesse comum:

\begin{abstract}
Não são de exclusiva competência local. E mais, não são também de competência exclusiva do Estado. Se fossem de competência exclusiva do Estado, reduzidas a sua competência residual (remanescente), este não necessitaria, em tese, de editar lei complementar para a execução de funções ou serviços regionais de que seria normalmente o titular, e sobre o qual já haveria mesmo a gestão unificada supramunicipal.
\end{abstract}

O exercício dessa competência comum no universo metropolitano ocorreria por meio da entidade metropolitana, qualificada pelo autor como uma espécie de "autarquia territorial plurifuncional", que desempenharia o papel de "titular derivado" das funções comuns. O Estado cria e organiza a entidade administrativa por meio de lei complementar, mas não pode deixar de admitir a participação dos Municípios nas decisões sobre os assuntos regionais que, em última instância, refletem seus interesses locais (ALVES, 1999, p. 63). Tudo isso equivale a dizer que a gestão isolada da região metropolitana pelo Estado é inconstitucional. Interessante notar que o autor não nega o caráter autárquico à região metropolitana, atribuindo, aparentemente, em virtude dessa afirmação, personalidade própria ao ente metropolitano.

Em suma, a região metropolitana seria um ente público administrativo regional, de caráter territorial e intergovernamental, sem força legislativa, mas com estrutura suficiente para garantir a integração necessária ao desempenho de funções comuns. (ALVES, 1999, p. 66)

Segundo Alves (1999, p. 64), a região metropolitana implica simultaneamente a identidade e não identidade do Município. Estes não deixam de ser Municípios, porém sob uma nova forma e segundo novas exigências jurídicas: trata-se do Município metropolitano.

Condizente com isso, um dos relevantes pressupostos teóricos adotados pelo autor é o de que a autonomia dos Municípios não é restringida pelo surgimento da região metropolitana e pelo consequente compartilhamento de competências com o Estado, pois é condicionada desde o início pela própria Constituição que possibilita a instituição de regiões metropolitanas em função do novo contexto gerado por condições objetivas de caráter regional: 
Nesse sentido, a autonomia dos municípios metropolitanos, ao ser modificada quanto ao conteúdo ou matérias sobre as quais é exercida, não corresponde à idéia de que antes existia uma autonomia ampla e que, depois, com a criação da região metropolitana, da aglomeração urbana ou da microrregião, viesse a ser restringida, diminuindo-lhe o campo de atuação. Não é o que juridicamente ocorre, visto que se os municípios metropolitanos deixam de ter plena e exclusiva atuação sobre determinadas matérias, porque estas passam, pela exigência e natureza das coisas, a ser tratadas em nível regional, ganham, contudo, nova responsabilidade de caráter regional, pois terão que participar e decidir, em conjunto com outros entes político-administrativos, sobre a mesma matéria, agora em nível regional. (ALVES, 1999, p. 72)

As considerações de Alves são respaldadas por votos proferidos na já mencionada ADI n. 1.842-5.

O Ministro Joaquim Barbosa não vê confronto entre o estabelecimento de regiões metropolitanas e a autonomia municipal. Segundo o magistrado, a autonomia municipal não possui apenas aspecto negativo, por tornar o Município imune à interferência de outros entes federados. Possui, também, caráter positivo, por se exercer quando órgãos colegiados metropolitanos permitem que o Município seja ouvido e efetivamente decida sobre os interesses comuns da região. Apresenta, nesse contexto, duas conclusões complementares: $(i)$ a restrição à autonomia dos Municípios metropolitanos dáse desde a configuração normativa constitucional, e não a partir da criação individual de cada região metropolitana, e (ii) a autonomia municipal se realiza quando o Município, num contexto metropolitano, tem preservada a capacidade de decidir efetivamente sobre os destinos da região.

Assim, atribui a titularidade do exercício das funções públicas de interesse comum à "nova entidade público-territorial-administrativa, de caráter intergovernamental, que nasce em conseqüência da criação da região metropolitana".

O exercício das funções normativas, diretivas e administrativas do novo ente deve ser compartilhado com paridade entre estado e Municípios envolvidos.

Na mesma ADI 1.842-5, o Ministro Gilmar Mendes inicialmente noticia que o tema em debate envolve a preservação de dois importantes valores constitucionais: a autonomia municipal e a integração por meio das regiões metropolitanas, aglomerações urbanas e microrregiões.

Aproximando-se da posição defendia por Alves e pelo Ministro Joaquim Barbosa, pondera que o interesse comum presente na integração metropolitana não se confunde com o simples somatório dos interesses locais, sendo, em verdade, pertinente 
simultaneamente aos Estados e aos Municípios integrantes do agrupamento urbano (Municípios os quais devem integrar compulsoriamente a região metropolitana). ${ }^{74}$

Somente a decisão e a execução colegiadas a abranger Estados e Municípios seriam, segundo Gilmar Mendes, aptas a garantir o adequado atendimento do interesse comum, bem como suficientes para preservar o autogoverno e a autoadministração dos Municípios. Deve se evitar que o poder decisório e o poder concedente concentrem-se nas mãos de um único ente, seja o Estado Federado, seja o Município polo da região metropolitana.

Ressalta Gilmar Mendes que os serviços de água e esgoto manifestam-se normalmente sob a forma de monopólio natural e que a inadequação da prestação de serviço em um Município pode afetar a prestação nos Municípios próximos. Bem por isso, a solução para a questão reside, segundo o Ministro, no reconhecimento de sistema semelhante aos Kreise alemães, nos quais o agrupamento de Municípios, juntamente com o Estado Federado, detém a titularidade e o poder concedente referente aos serviços. ${ }^{75}$

\subsubsection{Consolidação de um entendimento a respeito da titularidade}

Pela exposição das diferentes opiniões sobre a titularidade dos serviços, foi possível dimensionar a complexidade que o tema comporta.

Demonstrou-se nos itens antecedentes a existência de três grandes vertentes a respeito da titularidade do saneamento. Dentre as posições descritas, reputa-se desde já como improcedente aquela que defende a titularidade exclusivamente estadual (quiçá da União a depender da abrangência dos serviços) quando presente interesse regional.

De fato, a competência exclusiva do Estado fere frontalmente a autonomia municipal assegurada constitucionalmente e deixa de lado o fato de que o interesse

\footnotetext{
${ }^{74}$ Conforme julgado na ADI n. 1.841/RJ, relator Ministro Carlos Velloso, e ADI 796/ES, relator Ministro Néri da Silveira.

${ }^{75}$ Em apoio ao afirmado na decisão, citam-se os ensinamentos de Krell ([s.d.], p. 44) a respeito dos Kreise alemães: "Nesse ponto, cabe fazer um excurso para uma instituição famosa da administração pública na Alemanha, o 'Kreis', cuja tradução adequada é 'circulo' ou 'circunscrição' municipal. A competência dos Kreise é baseada no princípio da subsidiariedade, quer dizer: somente aquelas funções que os próprios municípios não conseguem exercer sozinhos de maneira satisfatória, devem ser cumpridos pelo respectivo Kreis, que na média, integra de 20 a 30 municípios menores e rurais".
} 
regional passa pelo interesse local, do que decorre o inafastável imperativo de integração dos Municípios na gestão do saneamento, ainda que os serviços adquiram relevância ou características regionais.

Restam dois posicionamentos que devem se contrastados e ponderados: a titularidade conjugada dos Municípios e a titularidade partilhada entre Municípios e Estados (por vezes a envolver a União quando o interesse regional se referir a um interesse nacional ou que ultrapasse dois ou mais Estados).

A escolha de um dos posicionamentos remanescentes não é nada fácil. É preciso reconhecer que em ambos os casos acima descritos há prós e contras.

A consideração das vantagens e desvantagens das diferentes posições pode soar, para muitos, como uma equivocada visão utilitarista da aplicação do direito, ou seja, a consideração, na escolha de um posicionamento, de um conjunto de argumentos metajurídicos sem força para indicar uma solução para o problema em bases efetivamente jurídicas.

Em outras palavras, ao interprete não seria dado avaliar benefícios e prejuízos derivados da aplicação da norma, e sim desvendar a única e legítima interpretação decorrente da análise dos textos legais, independentemente de seus efeitos práticos.

Sem embargo dessas considerações, realizou-se, na sequência, uma avaliação ponderada dos aspectos positivos e negativos de cada tese sobre a titularidade dos serviços na gestão do saneamento com o intuito de se proporcionar um grande pano de fundo para sua completa intelecção, sem prejuízo, é claro, da identificação de postulados que independem de questões ditas "metajurídicas", já que assentadas apenas na interpretação do arcabouço normativo pertinente ao tema.

Almeja-se, com isso, criar um contexto interpretativo mais abrangente e realista sobre a titularidade do saneamento.

\subsubsection{Ponderação críticas em torno da tese da titularidade compartilhada}

A titularidade conjugada de diversos entes federados a depender da abrangência do interesse na prestação dos serviços é uma ideia muito atraente uma vez que 
oferece concreção ao federalismo de cooperação e se apresenta como solução salomônica, pois situada a meio termo entre a titularidade exclusivamente municipal e a titularidade exclusivamente estadual.

A tese da titularidade compartilhada dos serviços de saneamento implica a afirmação de uma competência comum dos entes federados, uma competência de natureza condominial.

Levando adiante os desdobramentos da ideia, o exercício de tais competências comuns, acaso efetivamente existentes, seria presidido pelo princípio da subsidiariedade, próprio dos sistemas federais.

A primazia para a execução das competências deve ser do ente federativo menor que, no que couber, deve ser auxiliado pelos demais entes. Somente quando inviável ou insuficiente a atuação do ente menor é que se legitima a atuação do ente imediatamente maior.

A par das vantagens destacadas, é preciso considerar que a ampla maioria das decisões e posições que defendem tal ponto de vista ocorre no contexto das regiões metropolitanas, ou seja, uma forma compulsória de integração dos Municípios.

Notadamente nos votos dos Ministros Joaquim Barbosa e Gilmar Mendes proferidos na ADI n. 1.842-5, fica claro que a necessidade de conjugação de titularidade decorre da criação do ambiente metropolitano (ou aglomeração urbana ou microrregião) pela lei complementar estadual, em atenção a um contexto fático (a existência de serviços comuns e um inequívoco interesse regional) que demanda essas figuras administrativas como solução gerencial.

Como ficaria o desenho da titularidade nas situações em que o interesse regional na prestação de serviços de saneamento existisse independentemente das regiões metropolitanas, aglomerações urbanas e microrregiões?

Para o bem da tese ora analisada, tem-se que também nas hipóteses distintas das previstas no art. $25, \S 3^{\circ}$, da Constituição, nas quais se verificasse um interesse regional, deveria haver o compartilhamento da titularidade dos serviços, sob pena de inconsistência e instabilidade jurídicas do critério adotado para definição das competências dos serviços, qual seja, a abrangência e o impacto regional da prestação. 
Note-se que, na prática atual, não se tem notícia de disputas pela titularidade dos serviços fora das regiões metropolitanas (ou figuras afins como aglomerações urbanas e microrregiões).

Seria, por exemplo, possível argumentar que as mesmas razões gerenciais para a gestão associada (art. 241 da CF) acabam por se configurar na região metropolitana, e nem por isso se questiona a competência municipal naquele caso.

Essas considerações preliminares parecem denotar que a tese da titularidade compartilhada não se apresenta como um sistema de divisão de competências aplicável a toda e qualquer situação que um interesse regional ou funções de interesse comum no saneamento se verifiquem.

A principal crítica a nesse ponto seria a de que a solução da titularidade conjunta nas regiões metropolitanas não oferece segurança jurídica e homogeneidade para o tratamento do tema das competências em todo o setor. Não seria viável ter um critério de titularidade para as regiões metropolitanas e outros em que um interesse regional pudesse se manifestar também.

Algumas ponderações poderiam ser colocadas para contornar a contradição acima aventada.

Seria possível reafirmar e esclarecer a aplicação da noção de subsidiariedade no exercício de competências comuns ao argumento de que o interesse regional que fundamenta as regiões metropolitanas é um interesse qualificado (o interesse metropolitano). A constatação da existência do interesse metropolitano pelo Estado equivaleria ao indicativo de que, na perspectiva de uma atuação subsidiária, a ele caberia intervir por meio de lei complementar para assegurar a integração das funções comuns (juntamente com os Municípios).

As demais hipóteses de interesse regional deveriam ser avaliadas caso a caso a fim de justificar ou não a intervenção do Estado.

Mais uma vez o exemplo da gestão associada é pertinente. Se dois ou mais Municípios decidem se associar voluntariamente para prestar os serviços, tal não demandaria, necessariamente, a participação do Estado, já que esse só deve intervir quando os entes locais não apresentarem condições de arcar com suas responsabilidades (subsidiariedade). 
A gestão associada e a consequente união de esforços simbolizariam a predisposição dos Municípios em resolver conjuntamente suas dificuldades, dispensada a atuação subsidiária do Estado. Enfim, a despeito da não participação do Estado, a competência continuaria a ser compartilhada, só não exercida em razão da noção de subsidiariedade que rege o exercício de competências comuns.

Se, eventualmente, no âmbito da gestão associada, os Municípios se mostrassem ineficientes na gestão dos serviços, caberia ao Estado apresentar-se como apoiador.

De igual modo, se dois Municípios ou mais não quisessem, por questões políticas, desempenhar associadamente (voluntariamente) funções de interesse comum, caberia ao Estado intervir para dirimir os problemas de organização.

Tais ponderações parecem conferir robustez à tese da titularidade conjunta, já que lhe conferem organicidade, homogeneidade, tendo em vista que a torna aplicável em qualquer hipótese de interesse regional. Seu pilar fundamental reside na noção de subsidiariedade, que não implica, sempre e necessariamente, a participação do Estado.

Contudo, as considerações em pauta não eliminam alguns problemas práticos e contradições desse sistema. $\mathrm{O}$ argumento da subsidiariedade não elimina o fato de que a definição do interesse regional é uma atividade complexa. Fora do contexto das regiões metropolitanas (em que a lei complementar bem ou mal figuraria como critério definitivo para definição da titularidade conjunta), remanesceria sempre o risco do prejuízo à segurança jurídica, pois os critérios para a definição de um interesse regional ou de uma função comum são por natureza fluidos, sendo fato que mesmo os serviços inquestionavelmente locais podem afetar Municípios limítrofes (v.g., o manejo de águas pluviais). Mais ainda, restaria sempre ao arbítrio do Estado, seja na região metropolitana, seja em outras situações de interesse regional, decidir quando os Municípios têm ou não condições de prestar os serviços.

Em suma, a definição da titularidade dependeria de dois critérios - o caráter regional e a insuficiência dos Municípios (isolados ou em conjunto) em solucionar os problemas verificados - que além de abertos e fluidos, seriam interpretados exclusivamente pelo Estado. 
Trata-se de um modelo que, nos seus fundamentos, se assemelha muito mais ao sistema de titularidade puramente estadual do que o modelo de titularidade conjunta, ainda que posteriormente as decisões sejam compartilhadas pelos entes federados.

Sempre que dois ou mais Municípios optassem por desenvolver voluntariamente ações compartilhadas de saneamento, surgiriam discussões sobre a existência ou não de interesse regional (primeiro problema a ser resolvido ${ }^{76}$ ) e, em caso positivo, se isso redundaria na obrigatória aceitação da participação do Estado (se este assim o desejasse por entender insuficiente a prestação municipal).

Reforce-se que não poderia o Estado, isoladamente, prestar o serviço (a não ser que os Municípios assim optassem). Tal tese já foi completamente excluída desta discussão por desconsiderar o interesse local que toda função ou serviço regional apresenta.

Impossibilitado de atuar isoladamente, a única opção do Estado seria atuar subsidiariamente e, ao mesmo tempo, integrar os Municípios na gestão (pois a ideia de atuação subsidiária estadual não exclui a participação daqueles). Saliente-se que após a alteração do art. 241 da Constituição pela Emenda n. 19/1998, é relativamente fácil defender o entendimento de que sempre que dois ou mais entes voluntariamente pretenderem gerir conjuntamente serviços públicos, deverão observar os preceitos da Lei n. 11.107/2005, e não outros possíveis mecanismos de integração. Assim, restaria ao Estado apenas solicitar sua inclusão na gestão associada.

Essa conclusão, assumida como verdadeira, poderia deturpar a noção de gestão associada de serviços públicos, pois esta pressupõe a adesão voluntária dos entes federados (a decisão de compartilhar a regulação e prestação dos serviços ocorre sponte propria).

Nesse contexto, a associação voluntária para gestão de serviços se transformaria, inadvertidamente, em uma hipótese de compulsória aceitação do Estado sempre que este sentisse algum grau de insuficiência na atuação dos entes locais. Ou seja, a

\footnotetext{
${ }^{76}$ Frise-se, conforme afirmado no item 3.3 deste trabalho, que nem todas as atividades objeto da gestão associada de serviços públicos devem possuir, obrigatoriamente, uma abrangência regional ou caracterizar uma função comum. O fundamento da gestão associada (diferentemente das regiões metropolitanas) não é, obrigatoriamente, o interesse regional ou a função comum a ser desempenhada, e sim o federalismo de cooperação já analisado no capítulo 3 deste trabalho. Sua instituição decorre de um ato de livre vontade dos interessados e poderia perfeitamente representar a união de esforços para suprir temas locais de cada município, mas que podem ser desempenhados conjuntamente com maior eficiência, para diminuição, por exemplo, de custos regulatórios. Em outras palavras, da instituição da gestão associada não se presume automaticamente e sempre um interesse regional, tornando mais complexa a identificação de funções comuns. A decisão a respeito da titularidade dependeria sempre de certa dose de discricionariedade, tendente a ver um interesse regional onde ele não existe, o que traria ainda mais insegurança para a prestação.
} 
subsidiariedade, e não a mais a vontade autônoma dos entes federados, ditaria os rumos da gestão associada, o que implicaria reformular consideravelmente as bases desse conceito, tal como vem sendo entendido pela doutrina.

Mais uma vez, para preservar o caráter voluntário da gestão associada, pode-se até argumentar que, se os Municípios não aceitassem a participação estadual (ou mesmo se tais Municípios não quisessem promover qualquer tipo de associação voluntária), bastaria a edição de lei complementar (que transformasse a região em área metropolitana, aglomeração urbana ou microrregião), a fim de se impor a gestão compartilhada aos ente locais.

A dificuldade desse raciocínio é que ele traz o operador do Direito de volta à estaca zero. Denota que apenas se editada lei complementar existe a titularidade conjugada, mostrando, mais uma vez, que o critério não é necessariamente homogêneo e sistêmico e que apresenta dificuldades de aplicação em um contexto em que a autonomia e a vontade dos Municípios devem ser consideradas. Mais ainda, por indicar que a titularidade compartilhada somente se concretiza se existente lei complementar, acaba fazendo depender a titularidade de um critério excessivamente formalista que, eventualmente, pode desconsiderar aspectos materiais relevantes.

A tese da titularidade conjunta funciona bem nas regiões metropolitanas, uma forma compulsória de organização dos Municípios, mas apresenta dificuldades quando considerada fora desse ambiente.

Além disso, como dito acima, haveria o risco da convivência em um mesmo território de múltiplas situações de titularidade a depender dos critérios utilizados em cada caso para: (i) aferição do caráter regional ou da existência de funções de interesse comum, (ii) da existência ou não de Municípios capazes para atuar conjuntamente sem o apoio do Estado (subsidiariedade) e (iii) também em razão do tipo de organização administrativa adotada, se compulsória (v.g., regiões metropolitanas) ou voluntária (gestão associada prevista no art. 241). ${ }^{77}$ Esse desenho intrincado dificultaria a delegação de serviços a

\footnotetext{
${ }^{77}$ Não há nada de errado com a ideia de um serviço público partilhado por todos os entes federados. Há, deveras, competências materiais sobre serviços públicos que são desempenhadas conjuntamente por vários níveis federativos. São exemplos a saúde e educação, serviços cuja prestação compete a todos as unidades federadas. A diferença é que nesses casos a Constituição foi clara, impondo um modelo de atuação coordenada a todos os entes políticos. Aqui, não cabe a discussão se o serviço é local ou regional para a definição de sua titularidade porque o Texto Maior, por meio de regra específica, já delimitou a competência conjunta para sua prestação. Além disso, as citadas atividades não são organizadas em redes, as múltiplas unidades de prestação dos serviços (postos de saúde, hospitais, escolas, universidades)
} 
particulares (em função da insegurança que provoca) e prejudicaria a expansão e universalização do saneamento.

Outro problema de aplicação prática se reflete no exercício de competências legislativas em um contexto de titularidade material comum do saneamento. Na perspectiva normativa, a titularidade material compartilhada redundaria em um sistema de competências legislativas concorrentes. Difícil cogitar outro sistema de repartição de competências legislativas nesse caso.

Aos entes de maior envergadura caberia a edição de normas gerais, enquanto aos entes de menor abrangência territorial caberia suplementar essa legislação.

É notório que, na prática, é muito difícil delimitar a competência para editar normas gerais. A experiência demonstra que os entes mais abrangentes tendem a esgotar os assuntos legislados, deixando pouco espaço para a autonomia das unidades políticas de menor envergadura, circunstância que nem mesmo os tribunais conseguem evitar. A atuação das cortes é pontual, tópica e, em curto e médio prazos, pouco pode fazer contra a profusão de normas detalhadas que são publicadas com supedâneo na competência para editar normas gerais.

Krell (2008) noticia que o federalismo alemão, diante dos problemas oriundos da excessiva expansão das leis quadro (leis de normas gerais) e seus efeitos, vem presenciando uma sensível reorganização das competências concorrentes entre União e Estados objetivando ao maior equilíbrio entre elas. De fato, em 2006 uma reforma federativa na Alemanha levou ao reposicionamento das competências concorrentes que, agora, se encontram subdivididas em competências "núcleo" (kernkompetenzen), competências de "necessidade" (Bedarfskompetenzen) e competências de "divergência" (Abweinchungskompetezen). Explica o autor o significado das respectivas categorias:

As leis federais editadas com base nas competências concorrentes de núcleo (art.
$72, \mathrm{I}, \mathrm{LF}$ ), a partir de agora, têm o efeito de bloquear temporal e materialmente a
legislação estadual nas respectivas áreas, sem que haja ainda a necessidade de
verificar, no caso concreto, se a regulamentação federa era precisa, visto que o
legislador constituinte partiu da premissa de que, no âmbito destes títulos de

pertencentes aos diversos entes podem ser geridas cada qual independentemente da atuação alheia e convivem em uma relação de complementaridade. Ou seja, nesses casos não existe o problema da segurança jurídica. Já no saneamento uma mesma infraestrutura poderia, ao menos em tese (admitida a titularidade conjunta por todos os entes), ser gerida pelas unidades federativa em conjunto a depender da abrangência do interesse em jogo. 
competência, esta necessidade sempre existirá. Ao contrário, na área de competências concorrentes de necessidade sempre deverá ser efetuado um exame adicional para verificar se 'o estabelecimento de condições de vida equivalentes no território federal ou a manutenção da unidade jurídica e econômica no interesse do Estado como um todo torna necessária uma regulamentação por lei federal' (art. 72, II, LF).

Uma categoria nova no Direito Constitucional alemão são as competências concorrentes de divergência (art. 72, III LF), para as quais foi transferida a maioria das matérias que estavam localizadas no âmbito das competências quadro. A sua especificidade reside na supressão do bloqueio temporal e material das leis estaduais pelas federais que, até então, caracterizava a categoria de competências concorrentes da LF. Após a reforma de 2006, os estados podem divergir das normas federais nas áreas discriminadas no art. 72, III, n. 1 até 6, LF, existindo, agora, nos limites, dos espaços de sua abrangência substancial, verdadeiras competências plenas duplas da União e dos Estados.

No entanto, o exercício desta competência por um estado não afeta a validade das normas federais correspondentes, pois elas apenas perderão sua eficácia no respectivo território estadual. Por outro lado, nada impede que a União volte a promulgar ma nova lei sobre a matéria, que prevalecerá devido a sua qualidade de lei posterior. (KRELL, 2008, p. 108-109)

Os aprimoramentos do sistema alemão apenas comprovam que a prerrogativa de editar leis gerais geralmente redunda em abusos que ferem a autonomia das unidades federas de menor envergadura.

Reconhece-se que, com exceção dos desvios que a tese da titularidade conjunta pode acarretar na aplicação do sistema de gestão associada dos serviços (art. 241 da Constituição), denotando uma verdadeira contradição, a menção aos demais problemas dela advindos (risco de insegurança jurídica e risco de invasão de competências legislativas) acabam soando como argumentos de caráter secundário (metajurídico), cujo papel é mais o de compor o pano de fundo da situação do que de defini-la por completo em termos exclusivamente jurídicos.

Importante clarificar que não se deseja que a aplicação e a interpretação de normas constitucionais sejam pautadas e condicionadas em razão da deturpação ou abusos cometidos por aqueles que devem concretizá-las (abusos na definição do que é o caráter regional, na caracterização da necessidade de atuação subsidiária estadual ou na elaboração de normas específicas quando deveriam se gerais).

Se a Constituição estabelece a titularidade comum ou concorrente, então esta deve ser buscada de modo eficiente, sempre em mira do "dever ser" instituído pela Lei Fundamental. A segurança jurídica e a respeito aos limites das competências legislativas concorrentes deve ser conquistada pela atuação responsável dos detentores das 
prerrogativas e não pela simples proibição do exercício da titularidade. Abusos, em tese, devem ser coibidos a posteriori.

Mesmo reconhecendo a força dessas colocações, é de se admitir que os Municípios sofreriam grande risco de desrespeito à sua autonomia caso prevalecente a tese da titularidade conjunta.

Ultrapassadas essas questões, note-se que existem poderosos argumentos (muitos dos quais já avaliados nos tópicos anteriores) que contrariam a noção de uma titularidade comum dos serviços do saneamento em um contexto regional, argumentos esses decorrentes não dos efeitos colaterais da titularidade conjunta, mas da interpretação direta do Texto Constitucional e do exame da natureza dos serviços de saneamento. Eles serão reposicionados adiante, agora sob um viés crítico.

\subsubsection{Ponderação críticas em torno da tese da titularidade municipal}

A tese da titularidade municipal apresenta a vantagem de estar em maior sintonia com as características estruturais do saneamento. A despeito de toda a discussão acima travada, é importante asseverar, ainda, que na maioria das vezes os serviços de saneamento possuem inequivocamente um caráter local.

Assim é com a limpeza urbana, a coleta de resíduos, a distribuição de água e a coleta de esgoto e o manejo de águas pluviais. Admite-se, como feito em outros pontos deste trabalho, que alguns desses serviços podem ser inseridos em um contexto de gestão compartilhada (gestão associada de que trata o art. 241 da CF), mas não em razão de um necessário e inequívoco caráter interlocal, e sim em decorrência dos benefícios que uma atuação conjunta pode oferecer e já explorados preliminarmente no item 3.3 deste trabalho.

Existem atividades, como a captação de água e a disposição final de esgotos, que podem, em alguns casos, atender a mais de uma localidade. O reconhecimento de uma função interlocal implicaria a conjugação de competências, em essência, municipais.

A titularidade municipal permite, ainda, um desenho mais claro das competências legislativas sobre saneamento, questão que será tratada com maior aprofundamento adiante. 
Outro aspecto positivo é que a titularidade municipal não contraria a noção de gestão associada dos serviços (art. $241 \mathrm{da} C F$ ), uma vez que permite não apenas a reunião dos Municípios, como também de outras figuras federativas (Estados e União) na gestão, em razão, exclusivamente, de suas vontades, sendo prescindível qualquer consideração em torno da subsidiariedade a nortear essa decisão.

Trata-se, ainda, de uma decorrência do art. 23, IX, da Constituição Federal que determina que compete a todos as unidades federadas promover programas de construção de moradias e a melhoria das condições habitacionais e de saneamento básico. A verdadeira abrangência do dispositivo não é definir a titularidade comum do saneamento, e sim afirmar a necessidade de cooperação federal para seu desempenho. Note-se que a Constituição usa a expressão "promover a melhoria das condições de saneamento", a qual, nem com muito esforço interpretativo, redunda na afirmação de uma competência comum do saneamento.

A titularidade municipal coaduna-se ainda com o tema das regiões metropolitanas, pois preserva a possibilidade de instituição dessas figuras regionais pelos Estados.

Há, aí, um efeito relevante e que simboliza uma possível desvantagem da tese: seguida esta à risca, não se poderia cogitar, nas regiões metropolitanas, aglomerações urbanas e microrregiões, da participação dos Estados no processo decisório metropolitano, em contrariedade ao que afirmam, portanto, Alves (1998) e os Ministros Joaquim Barbosa e Gilmar Mendes na ADI 1842-5, bem como no que toca às experiências de região metropolitana que podem ser encontradas no Brasil. Trata-se da posição do Ministro Jobim (na ADI n. 1.842-5), quando afirma que a competência do Estado, nesses casos, seria meramente procedimental e não material.

Poder-se-ia argumentar que, ainda que não seja co-titular dos serviços, o poderdever de integrar a organização, o planejamento e a execução de funções comuns pode exigir do Estado a participação nas decisões materiais atinentes à gestão. Não seria necessário ao Estado ser titular do serviço para ter voz ativa na gestão metropolitana, tampouco a partição na gestão denotaria tal titularidade.

Seguindo tal ideia, a inserção do Estado como partícipe da gestão metropolitana (ou figura afins) não ocorreria em virtude de possuir uma titularidade compartilhada com os Municípios, mas em razão de sua competência para integrar a 
organização, o planejamento e a execução de funções públicas de interesse comum (art. 25, $\S 3^{\mathrm{o}}$ da $\left.\mathrm{CF}\right) .^{78}$

Outra reconhecida dificuldade a incidir na tese da titularidade municipal deriva do fato de que serviços de abrangência regional correriam o risco de se submeterem a distintas determinações legislativas emanadas pelos entes federados implicados na prestação, cada qual a viger sobre o território do respectivo titular. Uma constatação que mitiga esse problema é a de que a ampla maioria das determinações atinentes à gestão concreta dos serviços (determinações regulatórias) pode ser produzida por normas infralegais. Assim, as decisões tomadas conjuntamente nas instâncias de negociação estabelecidas entre os entes federados poderiam ser travestidas em um arcabouço normativo coerente e não disperso e contraditório como poderia se dar em virtude da produção de regras pelo processo legislativo ordinário (sujeito em maior intensidade aos influxos políticos e não técnicos).

Inegável, também, que a titularidade municipal torna a organização da gestão dos serviços de abrangência regional consideravelmente mais complexa. A existência de inúmeros atores envolvidos, cada qual dotado do poder de expressar sua posição, aumenta exponencialmente os custos de transação e o risco de que concertações ou problemas políticos possam inviabilizar o funcionamento da prestação que deveria ser compartilhada. Muitas vezes, a dura realidade da Administração Pública tornará a cooperação federativa um esforço hercúleo.

Avalie-se, em outra perspectiva, que a noção de titularidade municipal dos serviços de saneamento permite a consolidação de um critério de titularidade de aplicação homogênea e sistêmico, que não apresenta as contradições e dificuldades da titularidade conjugada. Permite, ainda, o efetivo exercício de competências legislativas pelos Municípios, e não apenas a legislação suplementar cabível no caso de competências concorrentes.

\footnotetext{
${ }^{78}$ Nesse sentido, muitos defensores da titularidade exclusivamente estadual nas regiões metropolitanas reconheceram que a avocação de competências pelo Estado por meio de lei complementar não implicaria a exclusão dos municípios dos processos de decisão. Assim cogitou o Ministro Marco Aurélio em seu voto na ADI n. 1.842-5 e, também, Tácito (2000, p. 308) quando tratou do tema: "A Região Metropolitana pressupõe uma necessária e contínua competência estadual para a prestação do serviço público comum oferecido a uma comunidade que ultrapassa as fronteiras municipais, embora a lei instituidora possa admitir a ação conjunta do Estado e Municípios agrupados, como prevê o art. $153, \S 1^{\circ}$, da Constituição do Estado de São Paulo". Ora, a contrario sensu a participação estadual nas decisões regiões metropolitanas seria do mesmo modo bem-vinda, independentemente do fato da titularidade municipal.
} 
Em síntese, a despeito dos aspectos negativos que a tese comporta, a existência de um interesse regional na prestação dos serviços não altera a competência municipal para a prestação, apenas exige a subordinação compulsória ou voluntária (tratando-se de região metropolitana - e figuras afins - ou de gestão associada, respectivamente) ao planejamento regional e às normas de organização compartilhada.

Com efeito, a subordinação aos ditames regionais será uma realidade que os Municípios não poderão negar. A diferença é que decidirão conjuntamente sobre tais temas. Com isso, espera-se deixar claro que a assunção da tese da titularidade municipal não significa um posicionamento em prol de uma suposta autonomia municipal de caráter absoluto. O problema regional existe e deve ser levado em consideração e a mera afirmação da autonomia da unidade federada não pode ser suficiente para enfraquecer o cumprimento do dever de cooperação implícito na lógica federativa tal como exposto.

Estabelecida a titularidade municipal material no saneamento, passa-se ao tratamento da competência legislativa no setor.

\subsubsection{Compreensão das competências normativas à luz da titularidade do saneamento}

Após a construção de um entendimento sobre a titularidade dos serviços de saneamento será consideravelmente mais fácil visualizar as competências legislativas no setor.

Afirmar que ao Município cabe a gestão e a organização dos serviços de saneamento não quer dizer que a ele será dado esgotar os fundamentos legais que os disciplinam.

É fato que o exercício de competências materiais pressupõe o exercício de competências legislativas em alguma medida. Todavia, nem sempre o exercício dessa competência legislativa será pleno.

Os próximos itens serão dedicados a conformar o quadro geral de competências legislativas no saneamento e, sobretudo, permitirão esclarecer uma zona cinzenta de confluência entre Estados e Municípios na elaboração de normas sobre o saneamento. 


\subsubsection{A elaboração de diretrizes pela União}

Muito se discutiu a respeito da competência da União para edição da Lei Federal n. 11.445/2007. Curiosamente, o dispositivo constitucional que, alegadamente, confere sustentáculo à referida norma consta do art. 21 da Constituição, que prevê as competências materiais e não legislativas da União. $\mathrm{O}$ art. 21 determina que compete à União: "XX - instituir diretrizes para o desenvolvimento urbano, inclusive habitação, saneamento básico e transportes urbanos".

Definir diretrizes soa, em uma avaliação preliminar e perfunctória, como uma ação muito próxima a de produção de normas gerais.

A despeito das indefinições que a expressão carrega, o estabelecimento de diretrizes possui, para alguns autores, notas próprias e inconfundíveis.

Marques Neto leciona (2005c, p. 167) que, em comum com as normas gerais, as diretrizes são também gerais no seu conteúdo e quanto aos seus destinatários. De outro lado, ao contrário das normas gerais, não pressupõem particularização posterior, pois tendem a ser normas de aplicação direta, detentoras de um conteúdo programático e direcionado para a ação. Não se confundem com uma regulação abstrata ou principiológica, identificando-se com a necessidade de estruturar e operacionalizar o setor por meio da intervenção e do fomento.

Justen Filho (2005a, p. 225) afirma que a Constituição, no que insere a elaboração de diretrizes do desenvolvimento urbano no rol de competências materiais da União, buscou conferir ao dispositivo uma dimensão substancialmente diversa da prerrogativa para editar leis. A criação da diretriz equivaleria a uma disciplina de conduta que difere da norma geral por representar a eleição de fins e a escolha de soluções para questões práticas, em um sentido muito próximo ao da instituição de políticas públicas. (JUSTEN FILHO, 2005a , p. 225-226)

Para Porto Neto (2005, p. 82), o termo "diretriz”, na Constituição, refere-se a um "conjunto de normas (princípios e regras) que visam a organizar, planejar e criar procedimentos para a concretização de determinado assunto".

Segundo o autor, as diretrizes possuem uma conexão com as questões práticas que objetivam solucionar. Apresentam maior proximidade com o problema tutelado, fato 
que as leva a possuir um conteúdo mais pragmático e operacional. Isso não quer dizer que sejam formuladas à revelia de qualquer limite a ponto de disciplinar todos os aspectos da matéria visada.

Porto Neto (2005, p. 82) relaciona dois princípios constitucionais como barreiras à produção normativa da União nesses casos: o princípio da "predominância do interesse nacional" e o da "autonomia dos entes da Federação".

O primeiro impele a União a se situar no nível de generalidade compatível com questões nacionais. As determinações cristalizadas nas diretrizes devem aplicar-se a todo o território nacional. Ou seja, longe de disciplinar regras puramente concretas sobre a prestação dos serviços, buscam, antes, construir princípios que regem os serviços, delimitar conceitualmente as atividades do saneamento, estabelecer os requisitos para o exercício da sua titularidade e delegação, disciplinar em termos gerais a regulação social e econômica do saneamento, oferecer indicativos para a gestão compartilhada, dentre outros temas imponíveis indistintamente a qualquer ente federado.

Ao lado da predominância do interesse nacional, o princípio da autonomia dos entes da Federação impede a subtração de prerrogativas não pertencentes à União: trata-se da preservação da capacidade de auto-organização, de autolegislação, de autogoverno e de autoadministração das demais unidades federativas. (PORTO NETO, 2005, p. 83)

A necessidade de limites na instituição de diretrizes pela União em respeito à competência dos demais entes federados é reconhecida também por Barroso (2002, p. 8):

\footnotetext{
A União, portanto, poderá fixar parâmetros nacionais no que diz respeito à prestação do serviço de saneamento, como, e.g., de qualidade ou técnicos, de modo inclusive a inserir o saneamento na política nacional de gerenciamento dos recursos hídricos. Não custa lembrar que 'instituir diretrizes' não autoriza a União a exaurir o tema, de modo a esvaziar a autonomia dos entes federativos competentes para prestar o serviço.
}

Nesse ponto, há que se reconhecer que as diretrizes estabelecidas pela União assumem características semelhantes às de normas gerais (ainda que não sejam assim classificadas pela doutrina), uma vez que serão posteriormente complementadas ou suplementadas pela ação normativa dos titulares do saneamento.

Difícil negar, portanto, o caráter de "lei quadro" assumido pela Lei Federal n. 11.445/2007, tendo em vista que define os grandes limites a preservar na gestão do saneamento pelos respectivos titulares, fato reconhecido por Porto Neto (2005, p. 82): “Do 
ponto de vista formal, no âmbito do arranjo federal de competências, as diretrizes gerais não se distinguem das normas gerais, pois, uma vez fixadas pela União, podem ser suplementadas pelos Estados, Distrito Federal e Municípios [...]”.

Percebe-se que um dos aspectos mais relevantes no que concerne ao exercício das competências normativas a respeito do saneamento reside na existência de diversas instâncias que o disciplinarão. Cabe agora identificar como essa atividade legiferante de caráter suplementar irá se processar.

\subsubsection{O papel dos Estados e Municípios na produção normativa acerca do saneamento}

Como visto acima, além da competência da União para instituir diretrizes sobre desenvolvimento urbano, há ampla competência para especificar e suprir os as grandes linhas traçadas pela Lei n. 11.445/2007.

Adotou-se como linha argumentativa a ideia de que caberá fundamentalmente aos titulares da gestão e organização dos serviços preencher os espaços deixados pela legislação federal.

Como regra geral, a competência legislativa para compor os fundamentos do saneamento será, assim, da União, mediante a instituição de diretrizes, e dos Municípios, tendo em vista o disposto no art. 30, I, da Constituição Federal.

Caberá aos Municípios disciplinar a escolha e os parâmetros de atuação da entidade reguladora dos serviços, detalhar os parâmetros técnicos e econômicos para sua prestação, especificar a forma de participação social no controle do saneamento, precisar o direito dos usuários e muitos outros temas que, colocados apenas como linhas gerais na lei federal, demandam concretização em face das necessidades do local ou da região em que o saneamento será realizado.

Deve-se lembrar, ainda, a existência de normas editadas pelos Municípios para regular outras áreas de seu interesse local que acabam interferindo diretamente na gestão do saneamento.

Tenha-se como exemplo a edição dos códigos de obras que disciplinam a instalação obrigatória de sistemas de microdrenagem das águas pluviais no interior dos 
lotes urbanos. Do mesmo modo, o plano diretor dos Municípios e as leis que disciplinam o uso e ocupação do solo possuem inequívoca relação com a drenagem ao impedir a construção de prédios em determinadas zonas da cidade sujeitas a inundações, ao determinar o grau aceitável de impermeabilização do solo, bem como ao direcionar os rumos da urbanização da cidade.

Nesse momento, torna-se imperioso abordar uma importante questão: qual o papel legiferante do Estado nesse contexto?

Uma resposta adequada exige que sejam divisadas situações em que a atuação legislativa do Estado ocorre de modo distinto, quais sejam: (i) no âmbito das regiões metropolitanas, aglomerações urbanas e microrregiões e (ii) fora dessas hipótese de gestão compartilhada compulsória.

Existe, nas regiões metropolitanas, aglomerações urbanas e microrregiões, uma necessária e bem-vinda competência legislativa do Estado. Ela não possui caráter suplementar no sentido veiculado pelo $\S 2^{\circ}$ do art. 24 da Constituição, decorrendo, na verdade, diretamente do disposto no $\S 3^{\circ}$ do art. 25 da Carta de 1988.

Trata-se, portanto, da competência normativa para instituir e organizar os procedimentos que permitirão a integração dos Municípios limítrofes.

Certamente, o Estado não poderá interferir em aspectos materiais que devem ser definidos ou por legislação local dos Municípios envolvidos ou por decisão tomada no órgão colegiado metropolitano.

A competência do Estado destina-se, pois, a definir procedimentos, órgãos e instâncias que permitirão a integração das funções de interesse comum.

Embora seja difícil delimitar exaustivamente o rol de temas que poderiam ser tratados pelo Estado nesse contexto, alguns temas servem de ilustração: $(i)$ criação dos órgãos ou entidades colegiados de representação e decisão da região metropolitana, aglomeração urbana ou microrregião; (ii) a criação de órgão ou entidades de caráter executivo ou fiscalizatório vinculados ao órgão de representação da região metropolitana e a (iii) criação de fundos para gestão dos recursos metropolitanos, dentre outros assuntos.

Já em outras hipóteses que não envolvam a região metropolitana (e figuras afins), a competência legislativa do Estado se situa entre o respeito às diretrizes da União e à competência dos Municípios para suprir tais diretrizes. 
Isso não quer dizer que o Estado nada possa dispor. São comuns e bem-vindas as chamadas legislações de incentivo, que podem traçar um plano estadual de saneamento direcionado para o apoio à regionalização dos serviços, com papel significativo dos Estados na participação de esquemas associados de gestão de serviço público.

\subsubsection{Outras competências que afetam o saneamento}

O saneamento básico encontra-se, também, pautado ou influenciado por outros subsistemas de competência constantes da Constituição, cada qual dotado de um desenho próprio.

É o caso do sistema de gestão das águas cuja disciplina normativa cabe à União, nos termos do inciso IV do art. 22 da Constituição da República. ${ }^{79}$ A outorga do uso da água, controlada pela União e pelos Estados a depender da propriedade dos corpos hídricos (arts. 20 e 26 da CF) impacta diretamente os serviços de água e esgoto. ${ }^{80}$

$\mathrm{O}$ inciso VI do art. 24 da Carta Constitucional informa que compete à União e aos Estados, concorrentemente, legislar sobre proteção do meio ambiente e controle da poluição. Ou seja, o Município não figura nesse rol. Isso significa que o Município somente pode legislar para "suplementar a legislação federal e estadual no que couber" (art. 30, II, da CF). Em outros termos, somente se a legislação federal e estadual não tiver esgotado a matéria é que o Município pode, para atender ao interesse local, legislar sobre meio ambiente. Disso deflui que a competência legislativa do Município nessa matéria é quase como residual de, no que couber, preencher eventuais claros que tenham sido deixados pela legislação federal e estadual.

A segunda consequência é a de que os Municípios, ao exercerem suas competências sobre saneamento, deverão observar diretrizes normativas federais e

\footnotetext{
${ }^{79}$ Como já citado neste trabalho, com fundamento nessa competência, a União publicou a Lei n. 9.433, de 8 de janeiro de 1997, que trata da política nacional de recursos hídricos, regulamenta o sistema nacional de gerenciamento de recursos hídricos e os parâmetros gerais para outorga do direito de uso de tais recursos.

80 Nesse sentido o parágrafo único do art. $4^{\circ}$ da Lei n. 11.445/2007: “Art. $4^{\circ}$ Os recursos hídricos não integram os serviços públicos de saneamento básico. Parágrafo único. A utilização de recursos hídricos na prestação de serviços públicos de saneamento básico, inclusive para disposição ou diluição de esgotos e outros resíduos líquidos, é sujeita a outorga de direito de uso, nos termos da Lei n ${ }^{\circ} 9.433$, de 8 de janeiro de 1997, de seus regulamentos e das legislações estaduais."
} 
estaduais sobre meio ambiente, em especial licenciamento, procedimentos adequados de disposição final de resíduos, normas técnicas sobre tratamento de resíduos, etc.

Como visto no capítulo 2 deste trabalho, a produção normativa nessas áreas temáticas podem interferir na delimitação da responsabilidade pelos resíduos e na definição da abrangência dos resíduos sólidos urbanos, alterando, portanto, o objeto do saneamento nos termos da Lei n. 11.445/2007 (art. $6^{\circ}$ ).

Como se pode observar, a organização das competências normativas no saneamento é complexa e envolve muitos atores e zonas laterais de interferência que devem ser cuidadosamente observadas quando da organização dos serviços.

\subsection{A GESTÃO ASSOCIADA DE SERVIÇOS PÚBLICOS}

O mais recente passo em direção ao federalismo cooperativo foi dado pela Emenda à Constituição n. 19/1998 a qual, dentre outras alterações, conferiu nova redação ao art. 241, possibilitando a gestão associada de serviços públicos entre a União, Estados, Distrito Federal e Municípios que, para tanto, deverão organizar-se sob a forma de consórcios ou firmar convênios de cooperação.

Por meio das noções fundamentais solidificadas neste item, será possível visualizar as muitas possibilidades de organização dos entes federados em torno da gestão compartilhada dos serviços de saneamento básico abrangendo a prestação dos serviços, sua regulação, fiscalização, etc.

Quando pertinentes, problematizações específicas em torno da natureza ou operacionalidade de alguns dos institutos citados serão aprofundadas, mas sempre, frise-se, com a intenção de proporcionar uma análise mais acurada da prestação dos serviços de saneamento básico.

Nesse sentido, reconhece-se a existência de controvérsias e polêmicas em torno de muitos dos institutos implicados na gestão associada de serviços. A legislação que instituiu a gestão associada apresenta muitas lacunas e o fato de se tratar de modalidade de gestão relativamente recente em nosso ordenamento contribui para aumentar as dificuldades de aplicação. 
Tais questões somente serão referenciadas se relevantes para o tratamento do saneamento básico, assumindo-se como dados do direito positivo muitas das características dos consórcios públicos e convênios de cooperação.

Frise-se, assim, que a natureza e características jurídicas dos consórcios, convênios de cooperação serão utilizados como elementos acessórios para o estudo do saneamento, e não como foco principal de análise.

\subsubsection{O consórcio público}

A gestão associada de serviços públicos pressupõe, para sua realização, a formalização pelos entes federados de um consórcio público ou de um convênio de cooperação.

As noções apresentadas neste tópico servirão para indicar em termos gerais os requisitos ditados pela Lei n. 11.107/2005 (que regulamenta o art. 241 da Constituição da República) para constituição e funcionamento dessas figuras.

$\mathrm{Na}$ experiência pregressa à Lei n. 11.107/2005, diante da ausência de disposições regulamentadoras sobre a matéria, entendia-se que os consórcios não possuíam personalidade jurídica, sendo incapazes de, isoladamente, assumir direitos e obrigações.

À época, Meirelles (1993, p. 308-309) sugeriu que, paralelamente à formalização dos consórcios, fosse providenciada a criação de uma pessoa jurídica de direito privado, sem fins lucrativos, para ao gerenciamento dos serviços objeto do pacto consorcial.

Era comum também, na doutrina, o entendimento de que os consórcios destinavam-se a disciplinar relações de entes federados da mesma natureza (Municípios com Municípios e Estados com Estados, por exemplo), enquanto os convênios eram aplicados na regência da relação entre níveis federativos distintos (Estados com Municípios, por exemplo).

A Lei n. 11.107/2005 trouxe como nota diferenciadora no art. $1^{\circ}, \S 1^{\circ}$, a criação de nova entidade por meio da constituição do contrato de consórcio, a qual será submetida a regime jurídico de direito público ou de direito privado. 
O consórcio público consiste, assim, em contrato plurilateral que propiciará o surgimento de nova pessoa jurídica.

A celebração do contrato de consórcio exige a subscrição prévia de protocolo de intenções (art. $3^{\circ}$ ) que, nos termos do art. $5^{\circ}$ da lei, será ratificado por lei de cada um dos entes federados interessados. ${ }^{81} \mathrm{O}$ contrato de consórcio público, caso assim preveja, pode ser celebrado por apenas uma parcela dos entes da Federação que subscreveram o protocolo de intenções (art. $\left.5^{\circ}, \S 1^{\underline{o}}\right)$.

Entende-se que não é qualquer parcela de entes federados que poderá celebrar o contrato de consórcio, mas aquela que efetivamente proporcione efetividade às finalidades enumeradas no protocolo de intenções. De nada adiantaria, por exemplo, a instituição de consórcio para serviços de água e esgoto sem a participação do Município responsável por tornar viável o acesso a mananciais e corpos hídricos não existentes nas demais localidades.

A ratificação pode ser realizada com reserva que, aceita pelos demais entes subscritores, implicará consorciamento parcial ou condicional. A ratificação é dispensada na hipótese de ente da Federação que, antes de subscrever o protocolo, disciplinar por lei a sua participação no consórcio (art. $5^{\circ}, \S 4^{\circ}$ ).

A nova entidade (o consórcio), quando detentora de personalidade de direito público, é classificada como associação pública de caráter autárquico.

$\mathrm{O}$ inciso IV do art. $4^{\circ}$ da lei informa que a pessoa jurídica de direito privado a ser gerada com base no consórcio não possuirá fins econômicos, fato que restringe consideravelmente as formas jurídicas que podem ser adotadas para sua constituição (que deverá atender os requisitos da legislação civil - art. $6^{\circ}$ ).

Constata-se, pela leitura do art. 44 do Código Civil, que apenas a forma de associação civil poderia ser utilizada para criação da nova pessoa, já que as sociedades em geral possuem finalidades econômicas, as fundações possuem substrato em um patrimônio específico, e não na associação de pessoas (como no caso dos consórcios), e as

\footnotetext{
${ }^{81}$ Segundo Di Pietro (2008, p. 242), a “exigência de contrato de constituição de consórcio público, quando este for instituído como pessoa jurídica de direito público, é contraditória quando confrontada com a norma do art. $6^{\circ}$, inciso I. [...] Como todas as autarquias, a personalidade jurídica surge com a simples entrada em vigor das leis que as instituírem. A pessoa jurídica de direito público é criada por lei, conforme decorre do art. 37, IX, da Constituição. Por isso, o vocábulo ratificação é incorreto, já que dá a impressão de que a lei apenas aprova uma criação já feita pela Administração Pública".
} 
organizações religiosas e partidos políticos possuem, por óbvio, finalidades incompatíveis com as previstas na Lei n. 11.107/2005.

A aplicação do regime jurídico de direito privado não escusa o consórcio da observância de normas de direito público no que concerne à realização de licitação, celebração de contratos, prestação de contas e admissão de pessoal, que será regido pelo art. $6^{\circ}, \S 2^{\circ}$, da Consolidação das Leis do Trabalho (CLT).

Conforme determina o $\S 1^{0}$ do art. $6^{\circ}$ da Lei n. 11.107/2005, a associação pública integra a administração indireta de todos os entes da Federação consorciados, quedando-se a lei silente a respeito do consórcio com personalidade de direito privado. ${ }^{82}$

As cláusulas essenciais do protocolo de intenções são as enumeradas no art. $4^{\circ}$ da lei e envolvem disposições relativas aos consorciados, à vigência do consórcio, seu estatuto, órgãos deliberativos, forma de deliberação e tomada de decisão, indicação de representante legal, regras específicas para a gestão associada de serviços públicos, área de atuação do consórcio, dentre outros temas.

Convém delimitar os pontos críticos do protocolo de intenções no que toca ao saneamento, sem intenção de esgotar todas as disposições do art. $4^{\circ}$ da Lei.

$\mathrm{O}$ protocolo de intenções deve conferir especial atenção à indicação das finalidades do consórcio (art. $4^{\mathrm{o}}, \mathrm{I}$ ). Certamente, as finalidades mais comuns orbitarão em torno da obtenção de insumos não encontrados no território de Município isoladamente considerado ou em razão da necessidade de obtenção da escala econômica que ofereça sustentabilidade à prestação.

82 Alguns autores encontram dificuldades em aceitar a integração dos consórcios à administração indireta dos
entes consorciados. Nesse sentido, posiciona-se Dias $(2008$, p. 108-109): “As referências constantes da Lei
n. $11.107 / 2005$ e no Decreto n. $6.017 / 2007$ às relações que as entidades da administração indireta dos entes
consorciados e o próprio consórcio público poderão ter entre si, torna ainda mais confusa e
incompreensível a integração dos consórcios à organização da administração pública. Defende-se, de lege
ferenda, que os consórcios, sejam eles constituídos com personalidade jurídica de direito público ou
privado (admitindo-se, por amor ao debate, esta possibilidade), não integram e nem podem vir a integrar o
aparelho do Estado, nem total, nem parcialmente. Se os consórcios mantiverem com os entes políticos
relações de parceria, que resultem, inclusive, no fomento de suas atividades, o que haverá são sujeições
especiais dos mesmos ao regime jurídico-administrativo, conforme consignado em momentos anteriores
deste estudo". A respeito do silêncio da lei no que toca aos consórcios de direito privado, encontram-se
posições que não enxergam na omissão um impeditivo da qualificação dos consórcios de direito privado
como integrantes da administração indireta dos entes consorciados. Nesse sentido, Araújo e Magalhães
(2008, p. 134): "Contudo, seria desarrazoado interpretar a Lei como se ela estivesse e excluir tais pessoas
da Administração Indireta, uma vez que, conforme o art. 241 CF, o objetivo dos consórcios é a 'gestão
associada de serviços públicos'. Além disso, pela análise do art. $6^{\circ}$, $\S 2^{\circ}$, da Lei n. $11.107 / 2005$, percebe-se
que o regime jurídico das associações de direito privado é o mesmo das empresas públicas prestadoras de
serviço público, não havendo razão para desvincular as novas pessoas jurídicas da Administração Indireta”. 
Nesse ponto, não custa recordar que a gestão associada poderá ser constituída para tratar de temas que não possuem, necessariamente, caráter regional.

Com efeito, a gestão associada não se esgota no papel de integrar regionalmente as atividades do saneamento. Pode ser aplicada como instrumento de apoio na prestação dos serviços, também, nas situações em que eles poderiam ser desempenhados inteiramente no território de um único ente local.

Assim, mesmo serviços com características locais, como a coleta e transporte de resíduos e a drenagem urbana (passíveis de serem prestados inteiramente em um mesmo Município) podem ser integrados à gestão associada, com vista à economia de despesas regulatórias ou obtenção de desenhos mais eficientes de execução, fato que não os transforma em serviços de caráter regional.

Os consórcios públicos poderão ter um ou mais objetivos e os entes consorciados poderão consorciar-se em relação a todos ou apenas a parcela deles.

Deverá ser realizada, ainda, a opção pela personalidade de direito público ou privado (art. $\left.4^{\circ}, I V\right)$. O fato de que a entidade de direito privado será pessoa sem fins econômicos retira muitas das vantagens práticas da aplicação dessa figura, conclusão reforçada pela circunstância de que a personalidade de direito privado não afasta a observância das normas sobre celebração de contratos, admissão de pessoal, dentre outras. $^{83}$

O protocolo de intenções conterá ainda as seguintes determinações, especialmente relevantes para a gestão do saneamento:

(i) critérios para, em assuntos de interesse comum, autorizar o consórcio público a representar os entes da Federação consorciados perante outras esferas de governo (art. $\left.4^{\mathrm{o}}, \mathrm{V}\right)$;

(ii) previsão de que a assembleia geral é a instância máxima do consórcio público e o número de votos para as suas deliberações (art. $4^{\circ}$, VII).

${ }^{83}$ Dias (2008, p. 100) acredita que a personalidade de direito privado é incompatível com as atribuições que serão exercidas pelos consórcios públicos: "Considerando a impossibilidade de se criar, por lei, distinção entre os consórcios constituídos como pessoas jurídicas de direito privado e os consórcios constituídos como pessoas de direito público, em virtude da isonomia entre os mesmos, deve-se rechaçar a juridicidade em se constituir consórcio público com personalidade jurídica de direito privado, sobretudo pelas dificuldades em se definir seu regime jurídico de regência. $\mathrm{O}$ fato de existirem outras pessoas jurídicas de direito privado integrantes da administração indireta, tais como empresas públicas e sociedades de economia mista, não autoriza a aplicar tal analogia para o estudo dos consórcios públicos constituídos como pessoas jurídicas de direito privado". 
(iii) autorização para a gestão associada de serviços públicos, explicitando (art. $\left.4^{\mathrm{o}}, \mathrm{XI}\right)$ :

a) as competências cujo exercício se transferiu ao consórcio público;

b) os serviços públicos objeto da gestão associada e a área em que serão prestados;

c) a autorização para licitar ou outorgar concessão, permissão ou autorização da prestação dos serviços;

d) as condições a que o contrato de programa deve obedecer, no caso de a gestão associada envolver, também, a prestação de serviços por órgão ou entidade de um dos entes da Federação consorciados;

e) os critérios técnicos para cálculo do valor das tarifas e de outros preços públicos, bem como para seu reajuste ou revisão.

Note-se que o protocolo de intenções deve definir o número de votos que cada ente da Federação consorciado possuirá na assembleia geral, sendo assegurado ao menos um voto a cada ente consorciado $\left(\operatorname{art} .4^{\circ}, \S 2^{\circ}\right)$.

Seria conveniente estabelecer pesos diferenciados para os votos de entes federados que detenham maior importância na gestão associada dos serviços. Assim é que o Município em cujo território se encontre o aterro regional de resíduos poderia deter maior poder de decisão sobre temas atinentes ao desenvolvimento de serviços em sua circunscrição territorial. Outros exemplos são cabíveis e dependem da análise do caso concreto.

Da maneira semelhante, a alteração ou extinção do consórcio dependerá de instrumento aprovado em assembleia geral, ratificado mediante lei por todos os consorciados (art.12).

A criação de nova pessoa jurídica por meio do consorciamento abre um amplo leque de possibilidades de prestação dos serviços públicos, uma vez que o consórcio, no exercício dos objetivos de interesse comum dos entes consorciados, poderá (art. $2^{\circ}$ da Lei n. 11.107/2005):

(i) firmar ajustes ou acordos e receber auxílio financeiro de outras entidades e órgãos de governo;

(ii) promover desapropriações e instituir servidões; 
(iii) ser contratado pelos entes consorciados, dispensada a licitação, para o desempenho dos serviços;

(iv) emitir documentos de cobrança e a arrecadar tarifas e outros preços públicos pela prestação de serviços ou pelo uso de bens públicos por eles administrados, ou mediante autorização específica, pelo ente da Federação consorciado;

(v) outorgar concessão, permissão ou autorização de obras ou serviços públicos, mediante autorização prevista no consórcio púbico;

(vi) exercer funções regulatórias, conforme delegação de competência outorgada pelos consorciados.

A transferência de recursos públicos ao consórcio pelos entes consorciados será feita por meio do contrato de rateio. São características do referido contrato (art. $8^{\circ}$ da Lei n. 11.107/2005):

(i) será formalizado em cada exercício financeiro e seu prazo de vigência não será superior ao das dotações que o suportam, com exceção dos contratos que tenham por objeto exclusivamente projetos consistentes em programas e ações contemplados em plano plurianual ou a gestão associada de serviços públicos custeados por tarifas ou outros preços públicos;

(ii) é vedada a aplicação dos recursos oriundos do contrato de rateio em despesas genéricas;

(iii) os entes consorciados, isoladamente ou em conjunto, são partes legítimas para exigir o cumprimento das obrigações assumidas no contrato de rateio;

(iv) o ente consorciado que não consignar em sua lei orçamentária ou em créditos adicionais, as dotações suficientes para suportar as despesas assumidas por meio de contrato de rateio poderá ser excluído do consórcio após prévia suspensão.

Como se vê, o contrato de rateio foi alçado à condição de instrumento de organização financeira do consórcio público. O repasse de recursos, conquanto seja a função principal do contrato de rateio, não é a única a que se presta. Destacam-se duas razões motivadoras da sua existência: o imperativo da exigibilidade das obrigações financeiras assumidas entre os entes consorciados e a sistematização dos gastos a serem realizados de forma a permitir o controle das despesas por ente participante do consórcio 
(verdadeiro controle interno de aplicação de recursos efetivado pelas administrações diretas de cada ente federado participante).

Quanto à sistematização dos gastos a serem realizados, considerando-se o consórcio como integrante a administração indireta de todos os envolvidos, a ausência de uma divisão clara de obrigações financeiras entre a pluralidade de signatários poderia gerar problemas contábeis que prejudicariam sobremaneira a verificação do equilíbrio econômico-financeiro dos serviços, bem como a estruturação de seu regime tarifário.

O contrato de rateio funciona, nesse sentido, como um guia para a posterior prestação de contas aos entes federativos envolvidos e para a padronização contábil e financeira do consórcio. Possibilita, em suma, que a cada unidade federativa integrante da gestão associada seja atribuída sua parcela de responsabilidade financeira, contribuindo para operacionalização dos serviços.

Descritas as principais características dos consórcios, são apresentadas a seguir as notas fundamentais sobre os convênios de cooperação.

\subsubsection{O convênio de cooperação}

O convênio de cooperação praticamente não é tratado na Lei n. 11.107/2005. O caráter lacônico da lei prejudica em muito a definição das características fundamentais desse instituto.

A falta de clareza impacta a análise da gestão associada no saneamento, pois impede a obtenção de parâmetros institucionais claros e sólidos para a organização dos serviços segundo esse modelo, obrigando o intérprete a realizar ilações nem sempre seguras.

A bem da verdade, no que concerne aos convênios de cooperação, a ausência de padrões de aplicação do instituto representa um grande obstáculo para sua utilização, fruto da insegurança a respeito de suas características fundamentais.

Nas páginas seguintes, serão buscadas linhas gerais que permitam ao operador do direito tatear minimamente os contornos do convênio de cooperação na gestão do 
saneamento, em que pese o fato de que dificilmente as sugestões aventadas serão tidas como definitivas e indubitáveis.

A diferença principal entre o convênio e o consórcio é que o primeiro não proporciona a criação de nova pessoa jurídica integrante da administração indireta dos entes consorciados.

O regulamento da Lei de Consórcios (art. 2º, VIII, do Decreto n. 6.017/2007) informa ser o convênio de cooperação um "pacto firmado exclusivamente por entes da Federação, com o objetivo de autorizar a gestão associada de serviços públicos, desde que ratificado ou previamente disciplinado por lei editada por cada um deles".

$\mathrm{O}$ fato de se tratar de pacto firmado exclusivamente por entes da Federação condiz com o art. 241 da Constituição, que estabelece o convênio de cooperação, ao lado dos consórcios públicos, como um instrumento próprio dessas pessoas políticas. O dispositivo traduz a ideia de que o convênio de cooperação consiste em tipo especial de convênio, que por tratar da gestão associada de serviços públicos, diferencia-se dos demais pactos conveniais que podem ser firmados entre outras entidades da administração pública e entre tais entidades e a iniciativa privada.

O regulamento estabelece a ratificação ou disciplina legal como condição de validade dos convênios. Determinação semelhante consta do art. $31, \S 4^{\circ}$, da norma, segundo o qual o convênio de cooperação não produzirá efeitos entre os entes da Federação cooperantes que não o tenham disciplinado por lei.

A determinação não foi assimilada de maneira pacífica pela doutrina. Com efeito, a exigência de lei para instituição dos convênios de cooperação tem sido objeto de controvérsias.

De um lado, existem os argumentos contrários ao tratamento legal prévio, assentados em uma remansosa jurisprudência no Supremo Tribunal Federal que não vê a lei como condição para formalização de convênios, em respeito à preservação do princípio da separação de poderes. ${ }^{84}$

\footnotetext{
${ }^{84}$ Nesse sentido Araújo e Magalhães (2008, p. 134-135): "Diferentemente, não há qualquer exigência de autorização legislativa para a celebração de convênios, até porque, não há a criação de uma nova pessoa jurídica da Administração Indireta. Vale lembrar que é pacífico, no âmbito do Supremo Tribunal Federal, a inconstitucionalidade da exigência de autorização legislativa para a celebração de convênios pela Administração, entendimento que se estendia também à celebração de consórcios". São exemplos de decisões preferidas pelo STF e que afastam a incidência da autorização legislativa prévia para celebração de convênios: "ADI 676 / RJ - Rio de Janeiro - Ementa: [...] Norma que subordina convênios, acordos, contratos e atos de Secretários de Estado à aprovação da Assembléia Legislativa: inconstitucionalidade,
} 
Acrescente-se que, nos consórcios públicos, é a criação de nova pessoa jurídica que demanda o tratamento legal prévio (ratificação do protocolo de intenções), com o objetivo de contemplar a exigência do art. 37, XIX, da Constituição Federal para instituição de entidade da administração indireta. Nos convênios de cooperação tal justificativa não existe.

Percebe-se que os argumentos contrários à necessidade de ratificação ou tratamento legal para a validade dos convênios são pertinentes, sobretudo se considerarmos o histórico recente da utilização de convênios no Brasil, que prescinde do beneplácito legislativo.

Uma avaliação idônea da questão ora discutida demanda, todavia, o exame dos argumentos em prol da validade da exigência de lei prévia ou ratificação legal para os convênios de cooperação.

Sob tal perspectiva, a necessidade de lei decorreria da própria redação do art. 241 da Constituição, segundo o qual

\begin{abstract}
a União, os Estados, o Distrito Federal e os Municípios disciplinarão por meio de lei os consórcios públicos e os convênios de cooperação entre os entes federados, autorizando a gestão associada de serviços públicos, bem como a transferência total ou parcial de encargos, serviços, pessoal e bens essenciais à continuidade dos serviços transferidos. ${ }^{85}$
\end{abstract}

\footnotetext{
porque ofensiva ao princípio da independência e harmonia dos poderes. CF, art. $2^{\circ}$. II Inconstitucionalidade dos incisos XX e XXXI do art. 99 da Constituição do Estado do Rio de Janeiro. III Ação direta de inconstitucionalidade julgada procedente. ADI 770 / MG - Minas Gerais. Ação Direta de Inconstitucionalidade. Constituição do Estado de Minas Gerais. Artigo 181, incisos I e II. Acordos e convênios celebrados entre Municípios e demais entes da Federação. Aprovação prévia da Câmara Municipal. Inconstitucionalidade. Art. $2^{\circ}$ da Constituição Federal. Este Supremo Tribunal, por meio de reiteradas decisões, firmou o entendimento de que as normas que subordinam a celebração de convênios em geral, por órgãos do Executivo, à autorização prévia das Casas Legislativas Estaduais ou Municipais, ferem o princípio da independência dos Poderes, além de transgredir os limites do controle externo previsto na Constituição Federal. Precedentes: ADI n. 676/RJ, Rel. Min. Carlos Velloso, e ADI n. 165/MG, Rel. Min. Sepúlveda Pertence. Ação direta que se julga procedente."

${ }^{85}$ Monteiro (2009, p. 288, nota 7) defende a necessidade de lei prévia para a celebração de convênios de cooperação: "A necessidade de lei para a celebração de convênio de cooperação decorre diretamente do art. 241 da Constituição Federal quando estabelece que os entes federativos 'disciplinarão por meio de lei' os convênios, autorizando a gestão associada. Em alguns casos, quando houver delegação de competências municipais a Estado-membro, será possível sustentar já existir autorização para a gestão associada em lei estadual. A razão de ser da referida exigência é fazer com que o Estado esteja ciente e preparado para receber encargos derivados da transferência de serviços públicos municipais. Referida autorização não precisa ser específica, tampouco cogitar-se-ia de uma lei estadual autorizativa para cada novo convênio de cooperação a ser celebrado. Em geral, aliás, as Constituições Estaduais dizem ser competência privativa do Governador celebrar convênio com entidade de direito público (e a jurisprudência do STF, de há muito, entende ser atentatória ao princípio da separação de poderes a exigência de prévia autorização legislativa para o Executivo celebrar convênios)".
} 
O art. 241 da Carta de 1988 teria instituído, nessa perspectiva, uma competência legislativa concorrente dos entes federados para disciplinar os consórcios e convênios.

A disciplina legal dos convênios referida no dispositivo constitucional não simbolizaria mera autorização legislativa prévia e específica à celebração da cada acordo, mas uma lei dita estrutural, destinada a regrá-los, em cada unidade política, como instituto a ser aplicado em inúmeras situações (não se constituindo, portanto, em lei específica), observadas as normas gerais traçadas pela União.

O objetivo com a lei não seria conferir uma autorização para os entes federados firmarem convênio de cooperação, mas dotar tais atos de maior solidez e segurança jurídica uma vez que especificaria suas características fundamentais, omitidas pela Lei n. $11.107 / 2005$.

Raciocínio semelhante presidiria, por exemplo, a situação em que um Estado ou Município optasse por disciplinar ou especificar aspectos do instituto do contrato administrativo tratados como norma geral pela Lei n. 8.666/1993. Trata-se de medida plenamente possível e nem por isso se encontram posicionamentos qualificando tais leis de interferências legislativas vedadas pelo nosso sistema constitucional (separação de poderes).

Outro argumento a corroborar a necessidade de lei a disciplinar o convênio de cooperação nos entes federados seria o de que tais figuras diferem do tradicional desenho dos convênios entre entidades públicas, tendo em vista que proporcionam a delegação de competências exclusivas dos entes federados, indo além da cooperação em torno apenas de competências comuns. Para proporcionar a transferência de encargos privativos dos entes, necessário seria o devido apoio legal.

Contra essa posição está o fato de que lei ordinária dos entes federados não pode alterar a divisão de competências previstas na Constituição Federal. Para contornar esse obstáculo, caberia ponderar que a norma que flexibiliza a transferência de competências entre entes federados seria o próprio art. 241 da Constituição, e não a legislação ordinária dos entes federados. A importância da lei ordinária residiria muito mais na perspectiva do recebedor das competências que, por despender esforços e recursos de seus contribuintes em matérias que não eram originariamente dele, necessita do correspondente respaldo da lei. 
Assim, a lei seria necessária para possibilitar não a transferência de competências, mas seu recebimento e custeio.

Verifica-se que os argumentos em prol da necessidade de lei a disciplinar os convênios também existem e refletem preocupações louváveis em prol do maior segurança jurídica dos entes envolvidos na cooperação.

Necessário ou não, há que se reconhecer elevadas dificuldades práticas e teóricas no tratamento legal prévio (ou ratificação legal) dos convênios.

No aspecto prático, o fato de a legislação federal ter sido excessivamente omissa na definição de normas gerais para disciplina dos convênios torna imprecisa a tarefa de especificação normativa dessas figuras. Há, certamente, o risco de que dois ou mais entes federados estabeleçam determinações legais colidentes, que acabem dificultando ou mesmo impossibilitando formalização do convênio em razão de exigências inconciliáveis de cada parte.

Além desse problema, que indica mais uma questão de ordem procedimental do que um verdadeiro obstáculo de caráter jurídico, necessário seria buscar uma diferença ontológica entre os diferentes tipos de convênio firmados pelas entidades públicas a fim de reconhecer aqueles submetidos à exigência da lei (convênios de cooperação nos termos do art. 241) e aqueles não submetidos a esse requisito. Do contrário, todo e qualquer ato convenial seria condicionado à lei, subvertendo-se a noção de separação de poderes já assentada nessa matéria pelo Supremo Tribunal Federal.

Uma sugestão inicial para a diferenciação ontológica entre tais atos residiria no fato de que os convênios de cooperação tratam da gestão associada de serviços públicos, enquanto os demais convênios tratar de outras matérias de importância menor, como a simples transferência de recursos ou compartilhamento de dados e informações.

Toda essa digressão em torno dos argumentos em favor e contra a utilização de lei para disciplinar os convênios de cooperação denota a complexidade da questão.

Apenas a evolução e o amadurecimento da aplicação do instituto dos convênios de cooperação consolidarão a pertinência do tratamento legal como condição de validade desses acordos. A bem da verdade, tal amadurecimento indicará ainda outros aspectos dos convênios de cooperação não tratados expressamente pela Lei n. $11 / 107 / 2005$. 
Em homenagem ao princípio da segurança jurídica, não haveria problemas em se tratar dos convênios de cooperação por meio de lei dos entes federados, desde que reste claro que o fundamento para tanto não é a necessidade de prévia autorização legislativa, e sim a maior estabilidade ao instituto conferida pelo diploma legal.

É claro que, adotando-se esse posicionamento, as determinações do Decreto n. 6.017/2007 em torno do tratamento legal prévio dos convênios não podem ser lidas como obrigatórias, mas como alternativa facultada aos entes políticos.

Em relação aos demais aspectos de conteúdo e formatação dos convênios de cooperação, uma sugestão razoável é aquela que aplica a tais atos, apenas no que couber, algumas das características dos consórcios públicos. Por óbvio que todas as características decorrentes da criação de nova pessoa jurídica estarão excluídas desse exercício analógico.

De outro lado, alguns pontos do conteúdo mínimo exigido no protocolo de intenções dos consórcios podem servir de inspiração para a composição dos convênios: definição de objeto da gestão associada, prazo de duração, atribuições transferidas, serviços públicos compartilhados, etc.

Interessante, ainda, a previsão nos convênios de cooperação de instâncias de negociação e deliberação entre os conveniados, tornando o exercício da gestão associada uma atividade marcada pela discursividade e pelo constante contato entre os interessados.

Independentemente desses cuidados, é fato que os consórcios públicos se apresentam como opção mais clara e duradoura para a gestão associada de serviços públicos. Servirão para tratar de questões que envolvem compromissos mais complexos de longa duração e que impliquem elevados investimentos de parte dos interessados.

Antes de avaliar as possibilidades concretas em torno da gestão associada no saneamento, é necessário esclarecer os pontos de tangenciamento e as diferenças entre dois conceitos relacionados de organização de serviços: a gestão associada e a prestação regionalizada do saneamento. Dessa análise resultarão importantes indicativos para a distribuição das funções ora analisadas entre os entes federados interessados. 


\subsubsection{A gestão associada e a prestação regionalizada de serviços públicos}

Em muitas situações, a gestão associada do saneamento terá caráter nitidamente regional, por se tratar da prestação de serviços que ultrapassam o território de um Município.

A despeito desse caráter regional, é prudente informar que o conceito adotado não se confunde necessariamente com a definição de prestação regionalizada cristalizada no art. 14 da Lei n. 11.445/2007:

\footnotetext{
Art. 14: A prestação regionalizada de serviços públicos de saneamento básico é caracterizada por:

I - um único prestador do serviço para vários Municípios, contíguos ou não;

II - uniformidade de fiscalização e regulação dos serviços, inclusive de sua remuneração;

III - compatibilidade de planejamento.
}

Hipóteses existirão em que, mesmo com a presença de mais de um prestador de serviços $^{86}$ (em contrariedade, portanto, ao afirmado no inciso I do art. 14), se poderá falar em gestão associada de serviços públicos de saneamento, já que presentes ao menos uma multiplicidade de entes federados, atuando conjuntamente para desenvolver outros aspectos importantes, como a instituição de uma agência reguladora única que atue no território de todos os Municípios envolvidos ou que fiscalize todas as atividades desempenhadas pelos variados prestadores.

Também a necessidade de vários Municípios descrita no inciso I do art. 14 da lei não se revela um requisito indispensável para a gestão associada, que poderá ser instituída entre um Estado e um Município, por exemplo.

\footnotetext{
${ }^{86}$ Foi demonstrado no capítulo anterior deste trabalho que o saneamento, sobretudo no que toca à água e ao esgoto, são serviços em rede, constituídos por atividades que, necessariamente interligadas, apresentam cada qual características próprias que comportam sua prestação por diferentes operadores. O já mencionado art. 12 da Lei n. 11.445/2007 indica claramente a possibilidade de que em um mesmo ciclo de atividades possam conviver inúmeros prestadores. Exige o dispositivo que, "nos serviços públicos de saneamento básico em que mais de um prestador execute atividade interdependente com outra, a relação entre elas deverá ser regulada por contrato e haverá entidade única encarregada das funções de regulação e de fiscalização".
} 
No que toca à uniformidade de fiscalização e de regulação dos serviços, bem como de sua remuneração, prevista no inciso II do art. 14 da lei, a ideia adotada é imprecisa.

Não indica se a "uniformidade" simboliza o exercício de atividades de fiscalização e regulação por uma única entidade ou se a regulação e a fiscalização desempenhadas nos vários Municípios devem guardar um mínimo de similitude em seu conteúdo (independentemente de seu exercício por uma ou várias entidades reguladoras).

Observe-se que a uniformidade de remuneração em um contexto regional nem sempre é possível, pois os Municípios possuem situação econômica distinta, podendo demandar até políticas tarifárias diferenciadas, sendo essa a ideia subjacente nos subsídios cruzados.

De todo modo, será sempre possível que dois Municípios firmem convênio de cooperação com um Estado, possibilitando a formalização de contrato de programa com empresa estadual de saneamento que atuará na prestação de serviços nas duas localidades, mantendo cada Município suas competências de regulação e fiscalização.

Há que se reconhecer apenas que não é aconselhável que uma pluralidade de Municípios, que tenham optado por um único prestador dos serviços, possuam várias instâncias reguladoras com diferentes padrões de fiscalização e regulação, perdendo, com isso, escala, qualidade organizatória e planejamento integrado.

Note-se, também, que a existência de dois ou mais prestadores não alterará o fato de que tal gestão poderá apresentar caráter regional, embora não se encaixe no conceito estrito de prestação regionalizada definido no art. 14 da lei.

Tenha-se como exemplo uma situação de gestão associada com participação do Estado, em que dois ou mais Municípios possuam cada qual prestadores próprios dos serviços. A presença do Estado criará, em perspectivas variadas, preocupações ou posturas regionais atinentes à gestão do sistema. A ponderação se mostra ainda mais pertinente tratando-se da prestação por múltiplos operados em uma mesma região metropolitana.

De outro lado, a gestão associada dos serviços públicos que envolva conjuntamente um Estado e apenas um Município (e não vários Municípios como exige o inciso I do art. 14) pode, sob certos aspectos, ser considerada uma gestão de caráter regional. 
O Estado em questão, ao participar do processo de gestão ou prestação dos serviços, certamente conferirá à sua atuação preocupações sistêmicas, em atenção a outras áreas ou necessidades do seu território: levará em consideração os corpos hídricos presentes em sua área ou as condições ambientais referentes ao descarte de resíduos; buscará, com o tempo, integrar a prestação de serviços do Município com a de outras localidades, bem como proporcionará condições de homogeneidade regulatória do saneamento.

Percebe-se que o legislador ordinário foi excessivamente restritivo na elaboração do art. 14 em pauta, deixando de lado hipóteses em que uma gestão associada de caráter regional dos serviços existirá sem que estejam presentes, obrigatoriamente, a totalidade dos critérios acima enumerados.

Destarte, enquanto a totalidade das características da prestação regionalizada (todas previstas no art. 14 da Lei Nacional de Saneamento) pode ser subsumida no conceito de gestão associada, a recíproca nem sempre será verdadeira. Avalie-se que os arts. 15 e 16 da Lei Nacional de Saneamento (adiante tratados) preveem mecanismos da gestão associada para dar concretude à prestação regionalizada, o que apenas comprova que esta é uma manifestação ou espécie daquela.

Uma conclusão importante é a de que a prestação regionalizada do art. 14 não é um modelo obrigatório a ser seguido sempre que Municípios desejarem compartilhar competências, podendo ser aplicadas outras funcionalidades decorrentes da gestão associada (mais abrangente, como demonstrado, que a prestação regionalizada).

De outro lado, justamente por ser um dos muitos modelos cabíveis de compartilhamento por gestão associada (e não o único), nada impede que as normas traçadas para a prestação regionalizada atinentes à regulação e à prestação de serviços sejam utilizadas como indicativos para melhor compreensão de toda a gestão associada. Essas normas serão estudadas abaixo quando pertinentes, notadamente os arts. 15 ao 18 da Lei Nacional de Saneamento. 


\subsubsection{A competência para a regulação, fiscalização e organização dos serviços de saneamento na gestão associada}

$\mathrm{O}$ art. $8^{\circ}$ determina que os titulares de serviços públicos de saneamento básico poderão delegar a "organização, a regulação, a fiscalização e a prestação desses serviços", nos termos do art. 241 da Constituição e da Lei n. 11.107/2005.

Neste tópico, trata-se, inicialmente, do arranjo competencial atinente à organização, regulação e fiscalização dos serviços, atividades que possuem conexões que naturalmente aproximam sua forma de gestão.

Além disso, o exercício da atividade de prestação dos serviços apresenta condicionantes específicos que justificam seu tratamento apartado.

Inicialmente, é de se cogitar da abrangência atribuída às expressões em pauta pela Lei Nacional de Saneamento e pela legislação sobre consórcios públicos e convênios de cooperação.

Após essa especificação conceitual, será possível delimitar a distribuição dessas competências na gestão associada do saneamento básico.

Será prudente inaugurar essas páginas de esclarecimento com a noção de regulação a ser aplicada no saneamento.

A literatura especializada costuma inserir no conceito de regulação atividades como elaboração de normas, ações de fiscalização, aplicação de sanções, competências adjudicatórias, solução de controvérsias e competências indutoras de comportamentos.

A leitura do art. $8^{\circ}$ da Lei de Saneamento, de seu lado, denota que alguns desses conceitos são por ela tratados distintamente (vale a pena reproduzir o dispositivo novamente: “Art. $8^{\circ}$ Os titulares dos serviços públicos de saneamento básico poderão delegar a organização, a regulação, a fiscalização e a prestação desses serviços, nos termos do art. 241 da Constituição Federal e da Lei no 11.107, de 6 de abril de 2005"). A norma coloca, portanto, a regulação no mesmo patamar de atividades de organização e fiscalização, e não como gênero a abarcá-las.

Assim, em uma primeira análise, uma interpretação coerente alocaria no conceito de regulação para fins de saneamento apenas as competências normativas 
relacionadas aos serviços ou atos que, embora não tenham caráter normativo, simbolizem determinação voltada para a sua disciplina técnica, econômica ou social.

Esse o conceito de regulação adotada pela legislação de consórcios públicos, nos termos do inciso XI do art. $3^{\circ}$ do Decreto Federal n. 6.017, de 17 de janeiro de 2007, e que pode ser estendido ao saneamento:

Art. $3^{\circ}[\ldots]$ :

$[\ldots]$

XI - regulação: todo e qualquer ato, normativo ou não, que discipline ou organize um determinado serviço público, incluindo suas características, padrões de qualidade, impacto sócio-ambiental, direitos e obrigações dos usuários e dos responsáveis por sua oferta ou prestação e fixação e revisão do valor de tarifas e outros preços públicos. ${ }^{87}$

A Lei de Saneamento estabelece como objetivos da regulação (art. 22): estabelecer padrões e normas para a adequada prestação dos serviços e para a satisfação dos usuários; garantir o cumprimento das condições e metas estabelecidas; prevenir e reprimir o abuso do poder econômico, ressalvada a competência dos órgãos integrantes do sistema nacional de defesa da concorrência; e definir tarifas que assegurem o equilíbrio econômico e financeiro dos contratos e a modicidade tarifária, mediante mecanismos que induzam a eficiência e eficácia dos serviços e que permitam a apropriação social dos ganhos de produtividade.

A entidade reguladora editará normas relativas às dimensões técnica, econômica e social de prestação dos serviços, que abrangerão, pelo menos, os seguintes aspectos (art. 23 da Lei Nacional de Saneamento): padrões e indicadores de qualidade da prestação dos serviços; requisitos operacionais e de manutenção dos sistemas; as metas progressivas de expansão e de qualidade dos serviços e os respectivos prazos; regime, estrutura e níveis tarifários e os procedimentos e prazos de sua fixação, reajuste e revisão; medição, faturamento e cobrança de serviços; monitoramento dos custos; avaliação da eficiência e eficácia dos serviços prestados; plano de contas e mecanismos de informação, auditoria e certificação; subsídios tarifários e não tarifários; padrões de atendimento ao público; mecanismos de participação social e informação aos usuários e medidas de contingências e de emergências, inclusive racionamento.

${ }^{87}$ O destaque dado aos termos "discipline ou organize" é proposital e visa denotar as relações entre os conceitos ora avaliados. 
Já o termo "organização" (contida no art. $8^{\circ}$ ) não possui um significado claro na lei. Em sentido geral, organizar poderia simbolizar ação que interfere em todas as fases de gestão dos serviços, desde a concepção dos modelos de prestação até o acompanhamento de sua realização concreta, a indicar parâmetros de prestação e de distribuição de tarefas.

Note-se que o conceito de regulação acima pinçado da legislação de consórcios utiliza a ideia de organização como uma das finalidades da ação regulatória, o que prova a inegável aproximação entre essas atividades (organizar e regular).

De modo semelhante, a Lei de Saneamento não apresenta um conceito de fiscalização. Também em analogia ao disposto no regulamento da Lei n. 11.107/2005 (inciso XII do art. $3^{\circ}$ do Decreto n. 6.017/2007), a fiscalização pode ser encarada como o conjunto de "atividades de acompanhamento, monitoramento, controle ou avaliação, no sentido de garantir a utilização, efetiva ou potencial, do serviço público".

Atente-se que é difícil tratar separadamente a regulação e a fiscalização, já que efetividade prática da primeira depende muitas vezes da eficiência da segunda atividade.

Objetivos da regulação, como a garantia do cumprimento de condições e metas dos serviços, a repressão do abuso do poder econômico e outros previstos no art. 22 da Lei n. 11.445/2007, são concretizados indiscutivelmente de modo sinérgico por meio de atribuições normativas e de fiscalização.

O fato é que as distinções conceituais adotadas pela lei e ora avaliadas não são muito precisas, não apresentando o diploma critérios ontológicos que justifiquem sua separação absoluta.

Ao final, o importante é ter em mente que, segundo o art. $8^{\circ}$ do diploma analisado, a organização, a regulação e a fiscalização podem ser objeto de delegação tal como expressamente autorizado pelo dispositivo analisado e em função do natural regime aplicável à gestão associada de serviços públicos, sendo aconselhável, pelas razões acima expostas, que tais funções sejam visualizadas como afins.

Em complemento ao quadro geral que se intenciona aqui compor, tem-se que o exercício da função de regulação atenderá aos seguintes princípios: independência decisória, incluindo autonomia administrativa, orçamentária e financeira da entidade reguladora e transparência, tecnicidade, celeridade e objetividade das decisões (art. 21 da Lei n. 11/445/2007). 
A exigência de autonomia administrativa, orçamentária e financeira da entidade reguladora denota, em uma primeira análise, uma tendência no saneamento à valorização de modelos como o das agências reguladoras, autarquias especiais permeadas por um regime que lhes confere maior independência decisória e financeira.

No entanto, nada impede que a função de regulação seja desempenhada por órgão desprovido de personalidade jurídica, mas suportado por um regime que lhe garanta um mínimo de autonomia decisória e receitas orçamentárias próprias.

Regra geral, os desenhos que implicam transferência das competências aqui avaliadas são variados, sendo improvável a possibilidade de esgotá-los neste trabalho. Será relevante, todavia, delinear as grandes linhas que regem essas atividades na gestão associada.

O art. 15 da Lei n. 11.445/2007, apesar de tratar da prestação regionalizada, oferece pistas interessantes para delimitação do arranjo competencial da regulação e fiscalização na gestão associada:

Art. 15. Na prestação regionalizada de serviços públicos de saneamento básico, as atividades de regulação e fiscalização poderão ser exercidas:

I - por órgão ou entidade de ente da Federação a que o titular tenha delegado o exercício dessas competências por meio de convênio de cooperação entre entes da Federação, obedecido o disposto no art. 241 da Constituição Federal;

II - por consórcio público de direito público integrado pelos titulares dos serviços.

Parágrafo único. No exercício das atividades de planejamento dos serviços a que se refere o caput deste artigo, o titular poderá receber cooperação técnica do respectivo Estado e basear-se em estudos fornecidos pelos prestadores.

A primeira constatação decorrente da interpretação do artigo retrotranscrito é a de que a regulação e a fiscalização (e porque não a organização dos serviços) poderão ser exercidas por órgão ou entidade de ente da federação que tenha recebido o exercício dessas competências por meio de convênio de cooperação (nesse caso, pressupõe-se que a entidade possua personalidade de direito público ${ }^{88}$ ).

${ }^{88}$ Conforme já aventado nesse trabalho, a personalidade de direito público é a compatível com o exercício de atribuições de regulação e fiscalização. 
Note-se que, para muitos, não seria dado ao titular dos serviços transferir, por meio de convênio de cooperação, responsabilidades que lhes foram atribuídas diretamente pelo Texto Constitucional. ${ }^{89}$

Os convênios de cooperação somente poderiam delegar atividades ou funções que não digam respeito ao âmago da regulação e da organização dos serviços, ou que se refiram apenas a competências comuns dos entes federados. ${ }^{90}$

A transferência de competências a consórcio público, de seu lado, não apresentaria tais restrições, vez que a delegação ocorre em favor de entidade integrante da administração indireta do outorgante, não implicando, nesse sentido, renúncia a atribuições constitucionais. As competências remanesceriam junto ao seu titular, pois atribuídas somente a um de seus braços descentralizados.

Como visto, ao menos a Lei Nacional de Saneamento indica ser possível que o convênio de cooperação transfira a outrem (ente federado ou entidade de sua administração indireta de direito público) o exercício de competência regulatória e de fiscalização, indo aparentemente de encontro às posições doutrinárias que não vêem como possível que um ente federado abdique em favor de outro o núcleo essencial de suas prerrogativas constitucionais.

Da leitura da Lei n. 11.445/2007 verifica-se que ela buscou, na verdade, uma posição intermediária entre as opiniões a respeito do objeto possível dos convênios de cooperação.

89 Assim entende Marques Neto (2005, p. 155-156) ao comentar o projeto que originou a Lei Nacional de Saneamento: "Ainda que, no presente contexto, a regulação esteja definida de maneira menos extensacontrapondo-se, por exemplo, à físcalização - deve-se reconhecer que os núcleos básicos da atividade regulatória, notadamente as competências normativas e adjudicatórias, devem permanecer intactos. A doutrina não parece dissentir em relação a este conceito, ainda que nem sempre seja tranqüila a definição das fronteiras da delegação. Nesse sentido, entre tantos outros, o pensamento de Alaôr Caffé Alves, que considera que a hipotética delegação pelo Município de competências materiais relacionadas à prestação dos serviços não faz com que se perca 'a substância jurídica dessa atividade, principalmente a normativa regulamentar, que corresponde ao exercício de sua autonomia em matéria de saneamento básico local.' Também para o autor os limites da delegação correspondem às intransferíveis funções de regulação e de controle da execução dos serviços públicos. Daí por que a transferência de competências por meio de convênio de cooperação só pode compreender atividades executórias que não digam respeito ao âmago da regulação do serviço".

${ }^{90}$ De outro lado, opiniões há que defendem a possibilidade de ampla delegação de competências, seja por meio do convênio de cooperação, seja por meio do consórcio. Monteiro (2009, p. 288) afirma: "Importante tema que deve ser definido no convênio de cooperação envolve a divisão de competências e a sua atribuição entre os entes conveniados. Pela letra da Lei n. 11.107/2005, qualquer arranjo é possível delegar o planejamento, a fiscalização, a regulação e/ou a prestação do serviço". 
Isso porque manteve (conforme será detalhado adiante) como prerrogativa exclusiva do titular dos serviços a elaboração dos planos de saneamento básico (art. 19 da Lei).

Ao asseverar que a elaboração dos planos é indelegável, quis o legislador ordinário determinar que a formulação da política pública para os serviços de saneamento pertence apenas e tão-somente aos titulares. As demais atividades associadas à implantação dos serviços orbitarão em torno dessas diretrizes.

Deve-se lembrar de que não apenas a elaboração de planos, mas também a competência legislativa primordial a respeito dos serviços compete aos Municípios, o que permite um tratamento legislativo dos temas fundamentais a respeito do saneamento, restringindo ainda mais o objeto da delegação por meio de convênio de cooperação.

Desse modo, no saneamento, a delegação de competências regulatórias, mesmo que por meio de convênios de cooperação, não implicaria uma transferência aberta e sem balizas, mas, sempre, uma outorga que deverá observar as políticas públicas traçadas pelo titular por meio da ação de planejamento e da elaboração de leis.

Será prudente, em todos os casos, que o próprio convênio de cooperação discipline, também, aspectos fundamentais da atividade regulatória, sobretudo no que concerne aos elementos econômicos da prestação.

Para os temas de difícil antecipação, pode o pacto convenial definir instâncias de discussão e deliberação, como no caso dos consórcios públicos. O objetivo será sempre o de determinar, com a participação dos titulares, as diretrizes para o direcionamento das ações transferidas (discursividade).

Continuando a análise da gestão associada no saneamento, o art. 15 acima transcrito demonstra ainda que, na hipótese de constituição de entidade por meio do consórcio público, esta poderá receber competências regulatórias e de fiscalização (e, por inferência, também de organização).

Nesse caso, o consórcio assumirá necessariamente personalidade de direito público, por determinação expressa do inciso II do art. 15 da Lei n. 11.445/2007: “Art. 15 [...] II - por consórcio público de direito público integrado pelos titulares dos serviços”. (Grifo nosso)

Outras determinações legais são importantes para delimitar o exercício da função regulatória no saneamento. A Lei n. 11.445/2007, no $\S 1^{\circ}$ do art. 23, informa: 
Art. 23. [...].

$\S 1^{\circ}$ a regulação de serviços públicos de saneamento básico poderá ser delegada pelos titulares a qualquer entidade reguladora constituída dentro dos limites do respectivo Estado, explicitando, no ato de delegação da regulação, a forma de atuação e a abrangência das atividades a serem desempenhadas pelas partes envolvidas.

A norma indica a impossibilidade de delegação das funções de regulação para entidades fora dos limites do Estado. O critério da lei parece ter sido geográfico, e não orgânico ou subjetivo. Ou seja, a expressão "dentro dos limites do respectivo Estado" não parece, e nem poderia, limitar a regulação apenas a órgãos e entidades do Estado-Membro, impondo, na verdade, que a regulação ocorra por entidade sediada no território do respectivo Estado.

O intuito da lei foi, provavelmente, asseverar o caráter regional que a regulação pode assumir no âmbito da gestão associada, conferindo, ainda, maior proximidade entre atividade regulatória e as necessidades concretas dos serviços em cada região.

Restringe, com isso, as possibilidades de que uma entidade da União, cuja sede situe-se fora do Estado, possa receber tais atribuições. Nada impede que entidade federal sediada no próprio Estado desempenhe a função regulatória. Será prudente também, nesse caso, que o objeto institucional da entidade seja atrelado a finalidades e ações desenvolvidas no Estado em que se situe.

Naturalmente, a delegação de que trata o art. 23 se realizará por meio da gestão associada, já que o referido dispositivo deve ser interpretado em conjunto com o conhecido art. $8^{\circ}$ da mesma lei, que estabelece esse modelo de gestão como o aplicável no saneamento quando em jogo a partilha de atribuições.

A tendência da Lei n. 11.445/2007 em incentivar a regionalização da regulação se encontra presente, ainda, no seu art. 24, que indica: "Em caso de gestão associada ou prestação regionalizada dos serviços, os titulares poderão adotar os mesmos critérios econômicos, sociais e técnicos da regulação em toda a área de abrangência da associação ou da prestação".

O dispositivo, a rigor, não seria necessário, já que a padronização de determinações regulatórias no âmbito da gestão associada representa uma decorrência normal do exercício dessa função, desde que, é claro, a adoção dos mesmos critérios 
econômicos, sociais e técnicos no âmbito da associação ou prestação se apresente pertinente e viável no que toca à sustentabilidade dos serviços.

Em razão das diretrizes acima descritas e considerando o perfil típico dos Municípios brasileiros, a tendência natural é a valorização da participação dos Estados na gestão associada.

Assim é que, no caso de convênio de cooperação, é previsível que o Estado ou autarquia por ele constituída receba as atribuições de organização, regulação e fiscalização dos serviços.

Também no caso dos consórcios, a participação do Estado como integrante da nova entidade criada também se revela um importante instrumento de desenvolvimento do saneamento, ao permitir que as entidades integrantes de sua administração possam ser alocadas na gestão dos serviços.

\subsubsection{Notas sobre o planejamento dos serviços no saneamento na gestão associada}

Como visto acima, o planejamento possui a relevante função de direcionar a ação de todos os envolvidos na prestação do saneamento, notadamente na gestão associada.

Maurer (2006, p. 479) afirma que o planejamento resulta de uma divisão de trabalho crescente no âmbito estatal, da redução dos meios à disposição do Poder Público, assim como necessidade de compatibilização de interesses diversos presentes em uma coletividade pluralista.

Muitas são as tentativas de compreender conceitualmente o plano. Todas elas se apresentam, contudo, mais como uma coleção de circunstâncias fáticas do que conceitos juridicamente claros. Há uma multiplicidade de planos que se distinguem pelo responsável pela sua elaboração, pelos seus destinatários, conteúdo, abrangência, efeitos temporais e caráter vinculante ou meramente indicativo.

Existe, assim, uma enorme dificuldade em se obter um conceito jurídico uniforme e abrangente a respeito dos planos. A expressão se apresenta, nesse contexto, como designação geral para manifestações muito diferentes entre si e que, justamente por 
isso, devem ser apreciadas segundo suas peculiaridades e prescrições jurídicas determinantes. (MAURER, 2006, p. 481)

Tais reflexões são pertinentes ao caso brasileiro, no qual muitas e variadas são as manifestações do planejamento: planos orçamentários, planos urbanísticos, planos econômicos, dentre outros.

Em comum, todas as ações de planejamento se caracterizam por ser um espaço de discricionariedade dos responsáveis na definição de metas, objetivos, programas e ações. Trata-se, segundo Bachof, Wolff e Stober (2006, p. 474), da discricionariedade de planificação, uma característica especial que os autores inserem no que denominam de “Administração conformadora".

No saneamento, a ação de planejamento poderia ser considerada como uma das atividades derivadas da competência para organizar os serviços (art. $8^{\circ}$ da Lei $n$. 11.445/2007). Contudo, optou a lei (arts. 19 e 20) por tratar o planejamento em termos próprios.

Conterão os planos de saneamento básico, no mínimo (caput do art. 19): (i) diagnóstico da situação e de seus impactos nas condições de vida, utilizando sistema de indicadores sanitários, epidemiológicos, ambientais e socioeconômicos e apontando as causas das deficiências detectadas; (ii) objetivos e metas de curto, médio e longo prazos para a universalização, admitidas soluções graduais e progressivas, observando a compatibilidade com os demais planos setoriais; (iii) programas, projetos e ações necessárias para atingir os objetivos e as metas, de modo compatível com os respectivos planos plurianuais e com outros planos governamentais correlatos, identificando possíveis fontes de financiamento; (iv) ações para emergências e contingências; e $(v)$ mecanismos e procedimentos para a avaliação sistemática da eficiência e eficácia das ações programadas.

Vários dispositivos da Lei n. 11.445/2007 incluem a atividade de planejamento como integrantes da competência dos titulares dos serviços. É o que diz o art. $9^{\circ}$ da lei ao dispor que "o titular dos serviços formulará a respectiva política pública de saneamento básico, devendo, para tanto: I - elaborar os planos de saneamento básico, nos termos desta Lei; $[\ldots] "$.

$\mathrm{O} \S 1^{\circ}$ do art. 19, de igual maneira, determina que "os planos de saneamento básico serão editados pelos titulares, podendo ser elaborados com base em estudos fornecidos pelos prestadores de cada serviço.”. Determinação complementada pelo $\S 2^{\circ}$ do 
mesmo dispositivo, segundo o qual a consolidação e compatibilização dos planos específicos de cada serviço serão efetuadas pelos respectivos titulares.

Note-se que a atividade de planejar não foi citada textualmente no art. $8^{\circ}$ (organizar, fiscalizar, regular e prestar), sinalizando uma restrição quanto à sua transferência a terceiros pelos titulares.

Também no art. 15 da lei há indícios dessa restrição. Determina o parágrafo único da norma que o exercício das atividades de planejamento dos serviços de regulação e fiscalização poderá receber cooperação técnica do respectivo Estado e basear-se em estudos fornecidos pelos prestadores. A norma qualifica o Estado como simples apoiador, eliminando qualquer possibilidade de que possa ser o responsável pela elaboração de todo o plano.

Tudo isso reforça a conclusão de que a atividade de planejamento não pode ser transferida a terceiros.

O legislador ordinário, ao determinar que a política pública para os serviços de saneamento (contida nos planos) pertence apenas e tão-somente aos titulares, garantiu-lhes uma esfera decisória indelegável, evitando a transferência de competências "em branco" a terceiros, já que o plano de saneamento condicionará as demais atividades relacionadas aos serviços (notadamente a regulação).

Quando envolvidos dois ou mais entes federados na prestação, os diversos planos emitidos pelos titulares deverão ser, no mínimo, compatíveis entre si (art. 14, III, da Lei n. 11.445/2007), podendo ainda ser elaborados para o conjunto dos Municípios atendidos (art. 17).

Assim, não poderia o convênio de cooperação delegar competência de planejamento dos serviços, mas lhe seria dado instituir condições institucionais para a realização conjunta da tarefa de planejar pelos respectivos titulares.

No caso de consórcios públicos, o fato de que integram a administração pública do titular pode ser utilizado como fundamento para que assuma responsabilidade pela formulação do plano, sem maiores prejuízos às determinações da Lei n. 11.445/2007.

Impõe a Lei de Saneamento, no art. 19, $\S 3^{\circ}$, a compatibilidade dos planos de saneamento básico com os planos das bacias hidrográficas em que estiverem inseridos.

Note-se que essa determinação se aplica tanto aos planos locais quanto àqueles realizados para o conjunto dos Municípios, circunstância que comprova uma preocupação 
com os efeitos regionais que a gestão do saneamento pode acarretar mesmo a partir de modelos locais de prestação.

Os planos de saneamento básico serão revistos periodicamente, em prazo não superior a quatro anos, anteriormente à elaboração do Plano Plurianual. Poderá, assim, o titular dos serviços empreender revisões a cada ano ou em intervalos maiores, desde que o período não ultrapasse o limite temporal determinado pela lei (art. $19, \S 4^{\circ}$, da Lei $n$. 11.445/2007).

Exceto quando regional, o plano de saneamento básico deverá englobar integralmente o território do ente da Federação que o elaborou ( $\operatorname{art.} 19, \S 8^{\circ}$ ).

Tendo em vista a premissa aqui utilizada de que os planos de saneamento, por cristalizarem a política pública dos titulares dos serviços, não podem ser objeto de delegação, além de condicionarem o desenvolvimento das demais atividades de gestão do saneamento, será prudente trazer à tona os principais aspectos a respeito de sua natureza e efeitos, ou seja, seus caracteres, limites, força vinculativa e capacidade de gerar direitos ou expectativas para terceiros.

Maurer (2006, p. 482) classifica os planos em indicativos (com a finalidade de informar instâncias estatais e privadas sobre circunstâncias e os rumos de desenvolvimento de determinada área ou setor); imperativos (consistindo em instrumentos que vinculam seus destinatários); ou influenciadores (elaborados para induzir condutas compatíveis com o plano por meio de subvenções, reduções ou incremento de impostos e outros mecanismos de incentivo ou direcionamento).

Os planos de saneamento, embora possam até apresentar elementos indicativos e influenciadores, são substancialmente imperativos. Isso porque têm por objeto um serviço público.

De fato, o saneamento, embora se configure como atividade econômica em sentido amplo, não perde sua nota essencial como serviço público. Nesse caso, o Poder Público não figura como agente normativo e regulador da atividade econômica nos termos do art. $174^{91}$ da Constituição, mas como titular das atividades de saneamento, do que deflui naturalmente a prerrogativa de planejamento e organização.

\footnotetext{
91 “Art. 174. Como agente normativo e regulador da atividade econômica, o Estado exercerá, na forma da lei, as funções de fiscalização, incentivo e planejamento, sendo este determinante para o setor público e indicativo para o setor privado.

$\S 1^{\circ}$ A lei estabelecerá as diretrizes e bases do planejamento do desenvolvimento nacional equilibrado, o qual incorporará e compatibilizará os planos nacionais e regionais de desenvolvimento.
} 
O plano se estabelece como norma do serviço e nessa qualidade deve ser obedecido por toda a Administração e pelos particulares que tenham se habilitado a prestálo por meio de institutos como o da concessão.

Muitos dispositivos da Lei n. 11.445/2007 corroboram esse posicionamento, tendo em vista que impõem a observância dos planos de saneamento básico pelos prestadores dos serviços. Na realidade, o plano passa a ser o parâmetro para elaboração de estudos técnicos e econômico-financeiros, definição dos planos de investimento e outras obrigações a serem formalizadas nos contratos de prestação:

(i) o inciso I do caput do art. 11 da lei informa ser condição de validade dos contratos que tenham por objeto a prestação de serviços públicos de saneamento básico $a$ existência de plano de saneamento básico;

(ii) o inciso II do caput do art. 11 da Lei demonstra que os estudos técnicos e econômico-financeiros deverão indicar os fundamentos da prestação universal e integral dos serviços nos termos do respectivo plano de saneamento básico;

(iii) o $\S 1^{\underline{0}}$ do art. 11 determina que os planos de investimentos e os projetos relativos ao contrato deverão ser compatíveis com o respectivo plano de saneamento básico;

(iv) o art. 13 possibilita aos entes da Federação, isoladamente ou reunidos em consórcios públicos, instituir fundos, aos quais poderão ser destinadas, entre outros recursos, parcelas das receitas dos serviços, com a finalidade de custear, na conformidade do disposto nos respectivos planos de saneamento básico, a universalização dos serviços públicos de saneamento básico;

(v) o $§ 6^{\circ}$ do art. 19 dispõe que a delegação de serviço de saneamento básico não dispensa o cumprimento pelo prestador do respectivo plano de saneamento básico em vigor à época da delegação;

(vi) o parágrafo único do art. 20 diz incumbir à entidade reguladora e fiscalizadora dos serviços a verificação do cumprimento dos planos de saneamento por

$\S 2^{\circ}$ A lei apoiará e estimulará o cooperativismo e outras formas de associativismo.

$\S 3^{\circ} \mathrm{O}$ Estado favorecerá a organização da atividade garimpeira em cooperativas, levando em conta a proteção do meio ambiente e a promoção econômico-social dos garimpeiros.

$\S 4^{\circ}$ As cooperativas a que se refere o parágrafo anterior terão prioridade na autorização ou concessão para pesquisa e lavra dos recursos e jazidas de minerais garimpáveis, nas áreas onde estejam atuando, e naquelas fixadas de acordo com o art. $21, \mathrm{XXV}$, na forma da lei." 
parte dos prestadores de serviços, na forma das disposições legais, regulamentares e contratuais.

Será conveniente, também, verificar em que medida a relação de tensão entre estabilidade e flexibilidade (MAURER, 2006, p. 487), própria do planejamento e inseparável da mutabilidade dos serviços públicos, influencia na conformação de legítimas expectativas no setor do saneamento, especialmente quando os serviços são prestados por terceiros contratados.

O imperativo de flexibilidade do plano casa-se perfeitamente com o fato de que necessidades coletivas se alteram e de que os serviços públicos se submetem a constantes pressões transformadoras. Não é sem razão que a Lei n. 11.445/2007 prevê revisões periódicas dos planos.

Para Bachof, Wolff e Stober (2006, p. 475), a liberdade na planificação, por eles denominada de comando de ponderação, não pode ser negada, desde que observados, é claro, os limites legais:

\footnotetext{
A Administração deve agir, nos limites da lei, com criatividade e de forma conformadora, segundo seus ideais de planificação, porque planificação sem liberdade de conformação seria em si uma contradição [...]. Para tal, são formulados os fins e interesses, isto é, os interesses públicos e privados divergentes que devem ser ponderados uns contra os outros e entre si (o chamado comando de ponderação). (Grifos dos autores)
}

A rigor, a mutabilidade dos planos se aproxima muito da mutabilidade a que se sujeitam os contratos de concessão de serviço público, pois derivada das necessidades dos sociais e sua já esperada volatilidade.

Assumida a possibilidade de alteração do plano de saneamento básico com o intuito de adaptá-lo às circunstâncias sociais, convém delimitar os efeitos que tais mudanças podem acarretar na esfera jurídica de terceiros.

Demonstrou-se que os contratos para prestação dos serviços de saneamento devem refletir os planos de saneamento básico. É natural, portanto, que mudanças nos planos possam demandar adaptações também nesses contratos.

A alteração do plano que redundar em modificações contratuais ensejará, se necessário e nos termos dos contratos, a recomposição da equação econômico-financeira estabelecida originariamente para a prestação realizada pela iniciativa privada. 
Se é fato que os planos não são imutáveis, os impactos de suas revisões não podem, contudo, privar os prestadores privados da preservação de seus direitos econômicos.

Da perspectiva dos usuários, é de se cogitar se os objetivos de universalização e outras metas traçadas nos planos de saneamento básico poderiam ser exigidos pelos cidadãos em face do Poder Público como uma espécie de direito público subjetivo.

A universalização dos serviços, que indiretamente comporta o direito de acesso do saneamento por todos os cidadãos, é um comando que, não se pode negar, impele a administração ao desempenho de todas as ações possíveis para a concretização do atendimento pleno.

Enquanto traçados no plano, tais objetivos e metas significam um norte a condicionar todas as ações do Poder Público no setor. Todavia, a eventual não consecução de metas de universalização não pode ser considerada, isoladamente, como uma fraude a uma suposta justa expectativa criada nos usuários pelo plano ou como causa suficiente a constituir, por exemplo, o direito de ação dos usuários contra o Poder Público a fim de que o objetivo proposto seja obrigatoriamente implantado.

$\mathrm{O}$ oferecimento de serviços como o de saneamento submete-se à noção da reserva do possível. Vale dizer, a concretização dos direitos econômicos, sociais e culturais (dentre os quais se insere o saneamento) é marcada pela gradualidade e depende da capacidade financeira e orçamentária do titular dos serviços.

O Ministro Celso Mello, em decisão proferida na Arguição de Descumprimento de Preceito Fundamental n. 45, leciona que os condicionamentos impostos pela cláusula da "reserva do possível" ao processo de concretização dos direitos de segunda geração (de implantação onerosa pelo Poder Público), conformam-se em um binônimo que compreende a razoabilidade da pretensão deduzida pelo indivíduo em face do Poder Público e a existência de disponibilidade financeira do Estado para tornar efetivas as prestações positivas que dele são reclamadas.

Comprovada a insuficiência de recursos e de outros meios da pessoa estatal, não seria razoável exigir o cumprimento de prestações positivas.

O controle da ação pública, nesses casos, não está apenas na constatação de que um fim previsto no plano foi ou não concretizado, mas na verificação de que os meios possíveis e existentes estão sendo empregados para sua consecução e, ainda, na fiscalização 
da compatibilidade das ações do Poder Público com as diretrizes cristalizadas no plano (enquanto tal plano não for, obviamente, alterado pelas revisões periódicas, quando novos parâmetros de adequação da ação administrativa surgirão com o plano renovado). ${ }^{92}$

O controle pelos usuários ocorre, assim, em várias, etapas: por meio da participação social na elaboração dos planos, em razão do exame das opções discricionárias tomadas pela Administração planificadora em face da realidade subjacente que visa planejar e no acompanhamento do desempenho das ações do Poder Público a fim fiscalizar sua coerência com o plano estabelecido.

Somente após esses procedimentos preliminares de controle e acompanhamento será possível afirmar se as metas não atingidas podem ser imputadas à leniência do Poder Público em relação ao plano vigente ou à reserva do possível.

Confirmam essa visão as opiniões de Bachof, Wolff e Stober (2006, p. 475), para quem os conceitos indeterminados subjacentes à atividade de ponderação e de escolha de fins própria da planificação são, na sua plenitude, susceptíveis de controle jurisdicional, o qual poderá abranger, ainda, as questões da legitimidade e da indispensabilidade do plano (justificação do plano).

Há, na planificação, o imperativo de equilibrar interesses. Deverão ser respeitados os comandos inerentes à atividade de planejar e relacionados à consideração de todos os interesses envolvidos, à distribuição possível dos ônus entre os destinatários do plano e da satisfação ótima dos interesses - trata-se do comando da otimização. (BACHOF, WOLFF; STOBER, 2006, p. 475)

\footnotetext{
${ }^{92} \mathrm{Na}$ Arguição de Descumprimento de Preceito Fundamental n. 45, o Ministro Celso Mello bem coloca os fundamentos e limites da "reserva do possível": "Não deixo de conferir, no entanto, assentadas tais premissas, significativo relevo ao tema pertinente à 'reserva do possível' (STEPHEN HOLMES/CASS R. SUNSTEIN, 'The Cost of Rights', 1999, Norton, New York), notadamente em sede de efetivação e implementação (sempre onerosas) dos direitos de segunda geração (direitos econômicos, sociais e culturais), cujo adimplemento, pelo Poder Público, impõe e exige, deste, prestações estatais positivas concretizadoras de tais prerrogativas individuais e/ou coletivas.

É que a realização dos direitos econômicos, sociais e culturais - além de caracterizar-se pela gradualidade de seu processo de concretização - depende, em grande medida, de um inescapável vínculo financeiro subordinado às possibilidades orçamentárias do Estado, de tal modo que, comprovada, objetivamente, a incapacidade econômico-financeira da pessoa estatal, desta não se poderá razoavelmente exigir, considerada a limitação material referida, a imediata efetivação do comando fundado no texto da Carta Política.

Não se mostrará lícito, no entanto, ao Poder Público, em tal hipótese - mediante indevida manipulação de sua atividade financeira e/ou político-administrativa - criar obstáculo artificial que revele o ilegítimo, arbitrário e censurável propósito de fraudar, de frustrar e de inviabilizar o estabelecimento e a preservação, em favor da pessoa e dos cidadãos, de condições matérias mínimas de existência”. (STF ADPF 45)
} 
Bem por isso, são apresentadas pelos autores as seguintes hipóteses que poderiam justificar o controle do planejamento:

(i) a constatação de um déficit de ponderação (falta de ponderação), quando a Administração não fez uso da sua discricionariedade de planificação ou deixou de considerar interesses sociais relevantes (p. 475);

(ii) a constatação de uma violação da ponderação, ou seja, quando se procede a uma planificação sem justificativa plausível ou com base em motivo dispensável (p. 476);

(iii) a constatação de um desvio de ponderação, representada pelo excesso de ponderação, pela falsa estimativa de ponderação ou pela desproporcionalidade de ponderação. $\mathrm{O}$ excesso de ponderação se dá quando tenham sido levados em consideração fins e interesses estranhos ao objeto do plano. A falsa estimativa de ponderação resulta da contradição entre o estabelecido no plano e o disposto em norma ou princípio. Já a desproporcionalidade de ponderação ocorre quando a planificação realizada encontra-se em contradição com o desenho objetivo de interesses individuais verificável na realidade (p. 476).

Nesse sentido, se existe algum direito público subjetivo de parte dos usuários, ele se refere à necessidade de que o planejador confira um tratamento isonômico aos interesses relevantes no seio da ponderação planificadora e observe, enquanto vigente o plano, as diretrizes nele contidas, observada a reserva do possível, ou seja, à medida que seus meios e recursos o permitirem.

É claro que quando incorporados a um contrato de concessão, os objetivos do plano se transformam em obrigações contratuais e seu inadimplemento pelo concessionário acarretará as conseqüências jurídicas próprias desse acordo administrativo. 


\subsubsection{A competência para outorgar concessão, permissão e autorização dos serviços de saneamento}

É admissível que o convênio de cooperação indique um órgão de ente federado ou entidade de sua administração indireta como responsável pela tarefa de outorgar a concessão, permissão e a autorização dos serviços de saneamento.

Trata-se da transferência da competência adjudicatória, ou seja, a prerrogativa de autorizar ou permitir o exercício de determinada função ou atividade.

De igual maneira, o consórcio pode ficar responsável, em nome dos entes federados, pela mesma atribuição de outorgar concessão, permissão e autorização a particulares que prestarão os serviços.

Em uma perspectiva regional, trata-se de uma importante função, pois permite que um mesmo prestador seja contratado para desempenhar os serviços em várias localidades, possibilitando a escala econômica eventualmente necessária para a sustentabilidade dos serviços.

$\mathrm{O}$ art. 20 do regulamento da Lei de Consórcios (Decreto n. 6.017/2007) determina serem condições para que a outorga dos serviços públicos por consórcios ocorra: a obediência à legislação de normas gerais em vigor e a autorização prevista no contrato de consórcio público. Tais determinações podem, tranquilamente, ser estendidas aos convênios de cooperação.

A autorização mencionada deverá indicar o objeto da concessão, permissão ou autorização e as condições a que deverá atender, inclusive metas de desempenho e os critérios para a fixação de tarifas ou de outros preços públicos (art. 20, $\S 1^{\circ}$, do Decreto $n$. 6.017/2007).

Naturalmente, a delegação dos serviços, regra geral, deverá ser precedida de licitação. A licitação será dispensada no caso da utilização de contrato de programa firmado sob o pálio de um consórcio público ou convênio de cooperação. ${ }^{93}$

\footnotetext{
93 Nesse sentido o art. 21 do Decreto n. 6.017/2007: "O consórcio público somente mediante licitação contratará concessão, permissão ou autorizará a prestação de serviços públicos. $\S 1^{\circ} \mathrm{O}$ disposto neste artigo aplica-se a todos os ajustes de natureza contratual, independentemente de serem denominados como convênios, acordos ou termos de cooperação ou de parceria. $\S 2^{\circ} \mathrm{O}$ disposto neste artigo não se aplica ao contrato de programa, que poderá ser contratado com dispensa de licitação conforme o art. 24, inciso XXVI, da Lei no 8.666, de 21 de junho de 1993".
} 
Segundo o regulamento do Decreto n. 6.017/2007 (art. 20, $\S 2^{\circ}$ ), dentre as possíveis prerrogativas do encarregado de outorgar os serviços se encontra a de "emitir documentos de cobrança e exercer atividades de arrecadação de tarifas e outros preços públicos pela prestação de serviços ou pelo uso ou outorga de uso de bens públicos ou, no caso de específica autorização, serviços ou bens de ente da Federação consorciado".

A bem da verdade, a cobrança de tarifas e preços públicos coaduna-se muito mais com a função do prestador dos serviços do que com a do outorgante dos serviços.

A colocação de tais questões no mesmo dispositivo do regulamento da Lei de Consórcios (art. 20) pode gerar certa confusão, sendo recomendável a separação de tais atribuições (outorga dos serviços e cobrança de tarifas). A cobrança pelo prestador pode favorecer sua autonomia, conferindo maior segurança ao processo de aquisição de receitas destinadas à remuneração do capital investido e ao custeio e à ampliação dos serviços, embora seja plenamente possível cogitar a cobrança pelo outorgante que, depois, poderá remunerar o prestador por meio de pagamentos diretos (desenho típico de uma concessão administrativa).

Entende-se admissível a conjugação de competências para regulação e fiscalização dos serviços e para delegação da sua prestação (e não prestação propriamente dita). Nessa hipótese, além de outorgante, remanesceria o consórcio (ou ente federado ou entidade no caso de convênio de cooperação) como responsável pela produção normativa e pela prática de atos de fiscalização do saneamento.

Não será possível, por certo, a conjugação de competências para prestar os serviços e regulá-los simultaneamente, já que tal confusão de papéis tornaria ineficiente e tendenciosa a ação regulatória.

\subsubsection{A prestação dos serviços de saneamento na gestão associada}

A prestação dos serviços na gestão associada admite, também, diversas formulações. É possível cogitar: (i) da permanência da prerrogativa de prestar os serviços com seus respectivos titulares (enquanto a regulação e a fiscalização podem, por exemplo, ser delegadas para o Estado, sua entidade ou consórcio público); (ii) da transferência da prestação 
ao consórcio público por meio de contrato de programa; ${ }^{94}$ (iii) da transferência da prestação a órgão ou entidade da administração indireta de ente federado consorciado ou conveniado, também por contrato de programa ${ }^{95}$; e, por fim, da (iv) delegação para a iniciativa privada, hipótese esta que pode ser concretizada pelo próprio titular ou por ente (ente federado, entidade da administração indireta ou consócio) a quem se tenha transferido competências adjudicatórias no âmbito de consórcio público ou convênio de cooperação.

Em sentido semelhante, dispõe o art. 16 da Lei Nacional de Saneamento ao enumerar os possíveis encarregados da prestação regionalizada:

\begin{abstract}
Art. 16. A prestação regionalizada de serviços públicos de saneamento básico poderá ser realizada por:

I - órgão, autarquia, fundação de direito público, consórcio público, empresa pública ou sociedade de economia mista estadual, do Distrito Federal, ou municipal, na forma da legislação;

II - empresa a que se tenham concedido os serviços.
\end{abstract}

Determina o art. 10 da Lei n. 11.445/2007 que "a prestação de serviços públicos de saneamento básico por entidade que não integre a administração do titular depende da celebração de contrato, sendo vedada a sua disciplina mediante convênios, termos de parceria ou outros instrumentos de natureza precária”.

94 Dispõe o art. 18 de Decreto n. 6.017/2007: “O consórcio público poderá ser contratado por ente consorciado, ou por entidade que integra a administração indireta deste último, sendo dispensada a licitação nos termos do art. $2^{\circ}$, inciso III, da Lei $n^{\circ} 11.107$, de 2005. Parágrafo único. O contrato previsto no caput, preferencialmente, deverá ser celebrado sempre quando o consórcio fornecer bens ou prestar serviços para um determinado ente consorciado, de forma a impedir que sejam eles custeados pelos demais". Deve-se lembrar que o protocolo de intenções deverá conter autorização para a gestão associada de serviços públicos, explicitando (art. $4^{\circ}, \mathrm{XI}$ ) as competências cujo exercício se transferiu ao consórcio público, os serviços públicos objeto da gestão associada e a área em que serão prestados, a autorização para licitar ou outorgar concessão, permissão ou autorização da prestação dos serviços, as condições a que deve obedecer o contrato de programa, no caso de a gestão associada envolver também a prestação de serviços por órgão ou entidade de um dos entes da Federação consorciados e os critérios técnicos para cálculo do valor das tarifas e de outros preços públicos, bem como para seu reajuste ou revisão.

95 Também nesse sentido o disposto no Decreto n. 6.017/2007: “Art. 31. Caso previsto no contrato de consórcio público ou em convênio de cooperação entre entes federados, admitir-se-á a celebração de contrato de programa de ente da Federação ou de consórcio público com autarquia, empresa pública ou sociedade de economia mista. $\S 1^{\circ}$ Para fins do caput, a autarquia, empresa pública ou sociedade de economia mista deverá integrar a administração indireta de ente da Federação que, por meio de consórcio público ou de convênio de cooperação, autorizou a gestão associada de serviço público. $\S 2^{\circ} \mathrm{O}$ contrato celebrado na forma prevista no caput deste artigo será automaticamente extinto no caso de o contratado não mais integrar a administração indireta do ente da Federação que autorizou a gestão associada de serviços públicos por meio de consórcio público ou de convênio de cooperação. $\$ 3^{\circ}$ É lícito ao contratante, em caso de contrato de programa celebrado com sociedade de economia mista ou com empresa pública, receber participação societária com o poder especial de impedir a alienação da empresa, a fim de evitar que o contrato de programa seja extinto na conformidade do previsto no $\S 2^{\circ}$ deste artigo. $\S 4^{\circ} \mathrm{O}$ convênio de cooperação não produzirá efeitos entre os entes da Federação cooperantes que não o tenham disciplinado por lei." 
O dispositivo em referência se aplica tanto no caso da delegação para privados quanto nas hipóteses de prestação por órgãos ou entidades da administração por meio de contrato de programa.

O dispositivo exclui da exigência contratual a prestação dos serviços por entidade que integra a administração do próprio titular. Nesse caso, a delegação se opera por força da finalidade legal que informa a criação e o funcionamento da entidade prestadora.

Tal raciocínio não se aplica, todavia, aos consórcios públicos, embora integrem a administração indireta das unidades políticas consorciadas. Isso em razão do disposto no art. 13 da Lei n. 11.107/2005, que exige o contrato de programa para disciplinar também as relações entre o ente federado e o consórcio público quando envolvida a prestação de serviço público, independentemente da colocação do consórcio como entidade da administração indireta daquele. ${ }^{96}$

Nesse caso, a existência do contrato de programa se faz necessária para maior controle da relação entre os envolvidos, raciocínio que se reflete no art. 18 do Decreto n. 6.017/2007, segundo o qual o consórcio público poderá ser contratado por ente consorciado, ou por entidade que integra a administração indireta deste último. Ainda segundo o dispositivo, o contrato deverá ser celebrado sempre quando o consórcio fornecer bens ou prestar serviços para um determinado ente consorciado, de forma a impedir que sejam eles custeados pelos demais. O contrato de programa funciona, assim, como mecanismo destinado a bem organizar investimentos na prestação de serviços públicos, evitando que a confusão de despesas e receitas dos consorciados.

Os contratos de prestação de serviços de saneamento, sejam eles contratos de concessão ou contratos de programa, dependerão, para sua validade (art. 11 da Lei n. 11.445/2007):

(i) da existência de plano de saneamento básico;

(ii) da existência de estudo comprovando a viabilidade técnica e econômicofinanceira da prestação universal e integral dos serviços, nos termos do respectivo plano de saneamento básico;

\footnotetext{
${ }^{96}$ Segundo o art.13 da Lei n. 11.107/2005, o contrato de programa presta-se à constituição e regulação das “obrigações que um ente da Federação constituir para com outro ente da Federação ou para com consórcio público no âmbito da gestão associada em que haja a prestação de serviços públicos ou a transferência total ou parcial de encargos, serviços, pessoal ou de bens necessários à continuidade dos serviços transferidos". (Grifo nosso)
} 
(iii) da existência de normas de regulação que prevejam os meios para o cumprimento das diretrizes na Lei n. 11.445/2007, incluindo a designação da entidade de regulação e de fiscalização;

(iv) da realização prévia de audiência e de consulta públicas sobre o edital de licitação, no caso de concessão, e sobre a minuta do contrato.

O conteúdo regulatório mínimo que irá reger os contratos de concessão e de programa é estabelecido pelo $\S 2^{\circ}$ do art. 11 da Lei n. 11.445/2007:

(i) a autorização para a contratação dos serviços, indicando os respectivos prazos e a área a ser atendida;

(ii) a inclusão, no contrato, das metas progressivas e graduais de expansão dos serviços, de qualidade, de eficiência e de uso racional da água, da energia e de outros recursos naturais, em conformidade com os serviços a serem prestados;

(iii) as prioridades de ação, compatíveis com as metas estabelecidas;

(iv) as condições de sustentabilidade e equilíbrio econômico-financeiro da prestação dos serviços, em regime de eficiência, incluindo:

a) o sistema de cobrança e a composição de taxas e tarifas;

b) a sistemática de reajustes e de revisões de taxas e tarifas;

c) a política de subsídios;

(v) mecanismos de controle social nas atividades de planejamento, regulação e fiscalização dos serviços;

(vi) as hipóteses de intervenção e de retomada dos serviços.

Considerando a elevada importância que os contratos de programa possuem na prestação dos serviços de saneamento no âmbito da gestão associada, convém dedicar tópico específico a respeito de seu funcionamento. 


\subsection{8 $O$ contrato de programa e sua aplicação no saneamento}

Medauar e Oliveira (2006, p. 105) inserem o contrato de programa no quadro referente à nova Administração Pública Consensual. Com apoio nas ponderações de Gaudin (1999), os autores se valem de três critérios formais para identificar os chamados contratos de ação pública, designação que visa retratar o gênero de todos esses novos contratos e acordos entre entidades públicas. Em primeiro lugar, a presença de um acordo negociado sobre os objetivos de uma ação pública. Em segundo, um compromisso de desenvolvimento dessas ações com base em cronogramas e orçamentos previamente estabelecidos. Como terceiro critério, constata-se a presença de obrigações recíprocas (v.g., financeiras, de gestão, de pessoas, técnicas) das partes visando à realização dos objetivos acordados.

O contrato de programa apresenta grande importância para o modelo da gestão associada. Importa sobremaneira delimitar suas funções e condições de formalização.

Segundo o art. 13, caput, da Lei n. 11.107/2005, o contrato de programa figura como condição de validade das

\footnotetext{
obrigações que um ente da Federação constituir para com outro ente da Federação ou para com consórcio público no âmbito da gestão associada em que haja a prestação de serviços públicos ou a transferência total ou parcial de encargos, serviços, pessoal ou de bens necessários à continuidade dos serviços transferidos.
}

Trata-se de instrumento obrigatório para as situações em que se queira atribuir a outrem, no seio da gestão associada (convênio de cooperação ou consórcio público) a prestação de serviços públicos que implique ou não a transferência de encargos, outros serviços e pessoal.

Entenda-se bem: havendo gestão associada (convênio de cooperação ou consórcio público) e existindo o interesse de atribuição a órgão ou entidade distinto do titular (consórcio público ou órgão ou entidade pertencente a outra unidade federativa) da prestação dos serviços públicos, o contrato de programa deverá, necessariamente, ser utilizado.

Tal instrumento será possível não apenas entre entes federados e entre estes e consórcios públicos, mas também entre outras entidades de direito público ou privado que integrem a administração indireta de qualquer das unidades da Federação consorciadas ou 
conveniadas, desde que previsto no contrato de consórcio público, ou de convênio de cooperação $\left(\S 5^{\circ}\right.$ do art. 13 da Lei n. 11.107/2005). ${ }^{97}$

Entende-se que o contrato de programa somente poderá ser formulado sob o pálio de um contrato de consórcio público ou convênio de cooperação. É o que decorre da interpretação direta do caput do art. 13 acima transcrito - quando afirma: "[...] no âmbito da gestão associada [...]" -, bem como de outros dispositivos da legislação ora estudada, tais como $^{98}$ :

(i) o inciso XVI do art. $2^{\circ}$ do Decreto n. 6.017/2007 conceitua o contrato de programa como o instrumento pelo qual devem ser constituídas e reguladas as obrigações que um ente da Federação, inclusive sua administração indireta, tenha para com outro ente da Federação, ou para com consórcio público, no âmbito da prestação de serviços públicos por meio de cooperação federativa;

(ii) o inciso XXVI do art. 24 da Lei n. 8.666/93 (acrescido pela Lei $n$. 11.107/2005), informa que é dispensável a licitação na hipótese de celebração de contrato de programa com ente da Federação ou com entidade de sua administração indireta, para a prestação de serviços públicos de forma associada nos termos do autorizado em contrato de consórcio público ou em convênio de cooperação;

(iii) o $\S 4^{\circ}$ do art. 13 da Lei n. 11.107/2005 determina que o contrato de programa continuará vigente mesmo quando extinto o consórcio público ou o convênio de cooperação que autorizou a gestão associada de serviços públicos. Por óbvio que se a lei se dá ao trabalho de afirmar a vigência do contrato de programa após a extinção do convênio e do consórcio, a contrario sensu, tais instrumentos deverão estar vigentes quando da formalização do contrato de programa;

(iv) o $\S 5^{\circ}$ do art. 13 da Lei n. 11.107/2005 determina que somente após previsão do contrato de consórcio público, ou de convênio de cooperação, o contrato de

\footnotetext{
97 O contrato celebrado entre as entidades será extinto no caso de o contratado não mais integrar a administração indireta do ente da Federação que autorizou a gestão associada de serviços públicos por meio de consórcio público ou de convênio de cooperação (art. 13, § $6^{\circ}$ da Lei n. 11.107/2005).

98 Alguns autores defendem uma aplicação autônoma do contrato de programa, independentemente da assinatura de convênio de cooperação ou criação de consórcio público. Nesse sentido Di Pietro (2008, p. 247): "Em resumo, existem várias possibilidades para a gestão associada de serviços públicos: a. a constituição de consórcio público com personalidade de direito público, sob a forma de associação pública; b. a constituição de consórcio público com personalidade de direito privado, sob a forma de associação civil; c. o convênio de cooperação; d. o contrato de programa que, por sua vez, pode estar vinculado a um consórcio público ou a um convênio de cooperação, podendo, inclusive, ser celebrado diretamente entre um ente federativo com entidade da Administração Indireta de outro ente federativo".
} 
programa poderá ser celebrado por entidades de direito público ou privado que integrem a administração indireta de qualquer dos entes da Federação consorciados ou conveniados.

A exigência prévia de consórcio público ou convênio de cooperação indica a clara intenção da lei de assegurar o contexto de cooperação federativa que permitirá e justificará a utilização do contrato de programa.

Seguindo o espírito da legislação, é o contexto de cooperação federativa delimitado pelos instrumentos de maior abrangência (consórcio e convênios) que criará as condições para a formalização do contrato de programa, a justificar inclusive a dispensa de licitação para contratação entre as citadas entidades.

Os consórcios e convênios disciplinarão as circunstâncias gerais da gestão associada de serviços públicos, descritas nos itens precedentes deste trabalho, enquanto os contratos de programa cuidarão das obrigações específicas da prestação de serviços públicos. Frise-se que somente podem ser signatários dos convênios e consórcios os entes federativos, sendo vedada a participação de entidades de sua administração.

O objeto dos contratos de programa é, com efeito, mais restrito que o dos convênios de cooperação e consórcios públicos (embora possa abarcar maior diversidade de signatários, como entidades da administração indireta).

Visa à disciplina prática da prestação dos serviços públicos, suas características técnicas e econômicas, notadamente as referentes ao cálculo de tarifas e aos demais aspectos da gestão econômica dos serviços. Se a gestão associada originar a transferência total ou parcial de encargos, serviços, pessoal e bens essenciais à continuidade dos serviços públicos objeto da prestação, o contrato de programa, sob pena de nulidade, deverá conter cláusulas que estabeleçam (art. 13, § $2^{\circ}$, da Lei n. 11.107/2005):

(i) os encargos transferidos e a responsabilidade subsidiária da entidade que os transferiu;

(ii) as penalidades no caso de inadimplência em relação aos encargos transferidos;

(iii) o momento de transferência dos serviços e os deveres relativos a sua continuidade;

(iv) a indicação de quem arcará com o ônus e os passivos do pessoal transferido; 
(v) a identificação dos bens que terão apenas a sua gestão e administração transferidas e o preço dos que sejam efetivamente alienados ao contratado;

(vi) o procedimento para o levantamento, cadastro e avaliação dos bens reversíveis que vierem a ser amortizados mediante receitas de tarifas ou outras emergentes da prestação dos serviços.

No $\S 3^{\circ}$ do art. 13 afirma-se que é nula a cláusula de contrato de programa que atribuir ao contratado o exercício dos poderes de planejamento, regulação e fiscalização dos serviços por ele próprio prestados.

Representa uma norma benfazeja, pois evita a problemática associação de competências de execução com as competências de controle, regulação e fiscalização dos serviços. Naturalmente, essa regra deverá ser respeitada em toda e qualquer situação e não apenas no caso da prestação por meio de contrato de programa. Em nenhuma hipótese o prestador dos serviços deve cumular as competências de regulação e fiscalização.

Por todas as características descritas, verifica-se que o contrato de programa assume funções próximas às de um contrato de concessão. Fortini e Rocha $(2009$, p. 148149) bem identificam essa característica ao afirmar:

\footnotetext{
O contrato de programa não é em si nenhuma novidade. Ele pode ser ajustado entre dois entes da federação, entre um ente federado e determinada entidade da Administração Indireta de outra esfera de governo e, finalmente, entre um ente federado e consórcio no qual não tenha assento.

Há muito se admite a existência da chamada 'concessão imprópria', ou 'concessãoconvênio', entre Municípios e entidades da Administração Indireta estaduais ou federais, por meio dos quais se entregava a estas últimas a execução de serviço público de titularidade do primeiro.
}

A lógica do modelo Planasa era exatamente esta: Municípios que se aproximavam das estatais estaduais para que estas prestassem o serviço.

Não sem razão, a Lei n. 11.107/2005 determina que o contrato de programa deve atender à legislação de concessões e permissões de serviços públicos, e, especialmente no que se refere ao cálculo de tarifas e de outros preços públicos, observar as normas de regulação dos serviços a serem prestados, bem como prever procedimentos 
que garantam a transparência da gestão econômica e financeira de cada serviço em relação a cada um de seus titulares ( $\$ 1^{\circ}$ do art. 13 da Lei n. 11.107/2005). ${ }^{99}$

Di Pietro (2008) vê grandes dificuldades na determinação de que o contrato de programa deva obediência à legislação de concessões e permissões de serviços públicos. Para a autora, é difícil cogitar que um ente federativo assuma a posição de concessionário em relação a outro ente federativo:

Quando muito, pode ocorrer que a entidade da Administração Indireta vinculada
a um ente Federativo (uma sociedade de economia mista ou empresa pública, por
exemplo) assuma, como concessionária, a prestação de serviço público de que é
titular determinado ente federativo. Isto já ocorre. É o caso da SABESP,
comumente contratada por municípios para a prestação de serviços públicos de
saneamento. E ocorreu, com grande freqüência, antes das privatizações de
empresas estatais, nas áreas de telecomunicações e energia elétrica, quando a
União, titular do serviço, os delegava, por concessão, a empresa estatal de outra
esfera de governo, como a Telesp, a Eletropaulo, a Cesp etc. (DI PIETRO, 2008,
p. 247)

Segundo Di Pietro (2008, p. 247), nos casos em que empresa estatal presta os serviços para outro ente federativo, a denominação de contrato de programa é imprópria porque se trata de verdadeiros contratos de concessão de serviços públicos que poderão adotar a forma de parceria público-privada, disciplinada pela Lei n. 11.079, de 30 de dezembro de 2004.

Diante das manifestações históricas e concretas da prestação dos serviços de saneamento, o contrato de programa se apresenta como uma clara tentativa para a regularização e sedimentação das relações entre Municípios e empresas estaduais prestadoras de serviço público de saneamento básico (oriundas do modelo Planasa).

É fato que, com a alteração do art. 241 da Constituição e com a edição da Lei n. 11.107/2005 e da Lei n. 11.445/2007, as relações institucionais entre empresas estaduais e Municípios deverão, paulatinamente, ser integradas à gestão associada de serviços públicos. No tópico seguinte, serão destacados alguns dos aspectos mais relevantes dessa interação.

\footnotetext{
${ }^{99}$ A alínea "d", inciso XI, art. 4 da Lei de Consórcios determina que o protocolo de intenções deve conter as condições a que deve obedecer o contrato de programa, no caso de a gestão associada envolver também a prestação de serviços por órgão ou entidade de um dos entes da Federação consorciados.
} 


\subsubsection{As empresas estaduais de saneamento na gestão associada}

A participação de empresas estatais na prestação dos serviços de saneamento é uma característica marcante do setor (notadamente nos serviços de água e esgoto).

Como visto no início deste trabalho, a delegação dos serviços às concessionárias estaduais por parte dos Municípios foi uma das principais bandeiras do Planasa.

É da relação entre empresas estatais e Municípios que deriva grande parte da estrutura de saneamento hoje existente no Brasil. Qualquer estudo da gestão compartilhada dos serviços deve considerar esse dado histórico.

Segundo o Sistema Nacional de Informações sobre Saneamento (SNIS) 80\% da população servida é atendida por operadoras estaduais (regionais), 16\% por operadoras municipais (locais) públicas e 4\%, por operadoras municipais (locais) privadas. (MOTTA, 2007, p. 184)

Devem ser reconhecidos os benefícios que o sistema proporcionou no que toca à expansão dos serviços. De fato, a história econômica brasileira indica que a presença do Estado foi crucial para a reprodução do capital em áreas sem atrativos a investidores privados e no saneamento não foi diferente. ${ }^{100}$

Em interessante estudo calcado nas análises de Willianson sobre custos de transação, Menard e Saussier (2002, p. 23) tentam oferecer uma explicação econômica para a escolha das formas de gestão dos serviços de água na França.

Embora reconheçam não haver uma vantagem absoluta em favor de um específico modelo, ressaltam que é possível encontrar vantagens comparativas associadas às características transacionais de cada qual. Para os autores, em alguns casos seria razoável afirmar que a atuação pública possui desempenho tão bom quanto o obtido por uma gestão privada.

\footnotetext{
${ }^{100}$ No exercício desse desiderato, o Poder Público pode ou não romper a forma de produção baseada na mercadoria. Quando opta pelo distanciamento do paradigma privado de produção, geralmente o faz com base em fluxo fiscal externo, de forma a comprometer sua racionalidade microeconômica e seu desempenho empresarial. Isso não deve ser visto como algo reprovável a priori. Representa, na verdade, ônus inafastável decorrente do caráter instrumental da empresa estatal, tida como mecanismo de planejamento, política industrial e regional. Assim "uma empresa estatal que estivesse submetida ao ideal do paradigma privado de produção, atuando como se privada fosse, romperia com a justificativa central de sua manutenção como empresa sob o controle patrimonial do Estado”. (MARTINS, 2007, p. 4)
} 
As seguintes proposições seriam ilustrativas de como as escolhas de modalidades de gestão por autoridades públicas seriam afetadas por condições de índole econômica:

(i) quanto maiores os investimentos requeridos para prover água em dada área, menor é a probabilidade de obtenção desses investimentos pela delegação, mantidas as demais variáveis constantes;

(ii) diante da necessidade de investimentos específicos para distribuição de água em certa área, maior é a incerteza na distribuição e menor é a probabilidade de obtenção desses investimentos mediante delegação, mantidas as demais variáveis constantes;

(iii) quando investimentos específicos de monta se encontram envolvidos, autoridades locais com orçamentos limitados, provavelmente, optarão pela delegação do que pelo provimento centralizado dos serviços, mantidas as demais variáveis constantes. (MENARD; SAUSSIER, 2002, p. 10-11)

Deve-se ter em mente que a transferência dos serviços para concessionárias estaduais, ainda que representativa de delegação em sentido formal a entidade com personalidade de direito privado, corresponde, indiretamente, a uma centralização dos serviços nas mãos do Poder Público (abstraindo-se, também, a circunstância de que muitas vezes estão envolvidas distintas esferas federativas). ${ }^{101}$

As afirmações realizadas coincidem com a evolução dos serviços de saneamento em nosso país, sendo previsível que, em atividades geradoras de externalidades sociais, ocorra maior apoio do Estado (diretamente ou por meio de suas empresas), sem prescindir, é claro da sempre possibilidade de delegação dos serviços para a iniciativa exclusivamente privada.

Evidentemente, não se pretende um determinismo econômico absoluto a comandar as decisões das autoridades públicas em torno da delegação de serviços públicos. Fatores políticos e sociais são importantes e devem ser levados em conta.

101 Não se quer afirmar que a participação da iniciativa privada não seja benéfica ou importante para o saneamento. Ocorre que, em última instância, a necessidade de investimentos de grande envergadura justifica uma forte presença estatal (ainda que por meio de suas empresas), só que agora em bases renovadas, que afastam os dilemas atinentes a confusão de papéis de regulação e prestação, proporcionando, ainda, o aprimoramento de competências locais e a participação popular na gestão dos serviços. 
O fato é que em um federalismo marcado pela preponderância dos entes de maior abrangência territorial, no qual a noção de subsidiariedade apresenta parca influência, as estatais detiveram e ainda detêm posição privilegiada no que toca à definição de arranjos contratuais e à organização dos serviços.

É notório, também, que as empresas estatais desempenharam papel multifacetado no saneamento: dedicaram-se simultaneamente à aplicação e desenvolvimento de políticas públicas e à persecução de uma atividade econômica (compreendida esta em seu sentido amplo). Acrescente-se que, considerando a parca regulamentação que até então existia no setor, exerceram, por vezes, a função de disciplinar o mercado por meio de determinações contratualmente estabelecidas.

O grande problema residia, justamente, no fato de que os referidos prestadores também desempenhavam funções tipicamente regulatórias, determinando até mesmo as características econômicas dos serviços (definição de valores tarifários).

A confusão entre regulador e prestador já denotava que esse modelo não poderia subsistir perenemente de forma completamente idônea. Com efeito, a relação entre a faceta pública e os anseios privados das empresas estaduais acabou pendendo em alguns casos em favor desse último, resultando em desvios previsíveis.

Ultrapassado esse momento histórico, a colocação das empresas estaduais, por meio da gestão associada, no seu verdadeiro e legítimo papel de prestadoras (e não reguladoras) dos serviços pode, efetivamente, auxiliar na continuidade e na ampliação do saneamento.

\subsection{AS REGIÕES METROPOLITANAS: UM OLHAR SOBRE OS SEUS DESAFIOS INSTITUCIONAIS}

As regiões metropolitanas, as aglomerações urbanas e as microrregiões constituem um fenômeno complexo, seja do ponto de vista socioeconômico, seja no que toca à perspectiva jurídica.

O tema metropolitano é, com efeito, o mais elaborado e problemático entre os acima mencionados. As questões metropolitanas abarcam problemas de índole geracional 
(criação), organizacional ou institucional (órgãos deliberativos e organização de atribuições) e de conteúdo (identificação das funções públicas de interesse comum e sua prestação eficiente).

Dados de 2006 trazidos por Lopes (2006, p. 150) indicam a existência de 28 áreas metropolitanas no Brasil (15 delas formadas em torno de capitais de Estados Federados, três delas caracterizadas como Regiões Integradas de Desenvolvimento (RIDES), instituídas por leis federais por serem constituídas de Municípios de Estados diferentes e do Distrito Federal, e as dez restantes concentradas nas regiões Sul e Sudeste).

Ainda segundo Lopes, as 28 regiões estão situadas no leste do território brasileiro, refletindo um padrão de rede urbana ainda fortemente marcado pela matriz colonial atlântica. Em termos numéricos, o conjunto das regiões metropolitanas concentra cerca de 70 milhões de habitantes, representando $45 \%$ da população total do Brasil. O total de Municípios incluídos nas regiões descritas é de 417, número fortemente incrementado, nos últimos vinte anos, pelo intenso processo de emancipação de novas unidades de administração municipal nas periferias dos grandes centros. (LOPES, 2006, p. 151)

Sabe-se que a construção da estrutura jurídica de gestão da região metropolitana deverá ter em conta o fato metropolitano em sua dimensão social e econômica para que as soluções propostas para o atendimento das demandas nelas presentes não sejam contraditórias ou ineficientes. Segundo Santos (2008, p. 84),

o fato metropolitano se apresenta como uma totalidade menor dentro da totalidade maior, constituída pela formação social nacional: só as aglomerações urbanas com certo nível de complexidade podem ser consideradas como totalidades, o que não cabe aos outros tipos de formações regionais. As metrópoles podem, desse modo, ser analisadas segundo um critério sistêmico, desde que a percepção das variáveis constitutivas seja alcançada. Um estudo substantivo pode, desse modo, ser buscado, o que, aliás, impõe-se, caso se deseje realmente conhecer o fenômeno e chegar a propor soluções. $O$ enfoque de planejamento não pode ser autônomo, mas subordinado ao conhecimento intrínseco da realidade global. ${ }^{102}$

102 As regiões metropolitanas, para o autor em referência, têm sido objeto de um planejamento setorial, que não atende às suas necessidades. No que toca aos serviços de interesse coletivo, a conseqüência desse tipo de planejamento seria sua excessiva concentração geográfica: "As atuais regiões metropolitanas têm como pontos comuns dois elementos essenciais: a) são formadas por mais um município, com o município núcleo - que lhes dá o nome - representando uma área bem maior que as demais; b) são objeto de programas especiais, levados diante por organismos regionais especialmente criados, com a utilização de normas e recursos em boa parte federais. São, na verdade, regiões de planejamento, onde, todavia, o que é feito não atende à problemática geral da área, limitando-se a aspectos setoriais. A sociedade capitalista favorecida pelo poder público nessas áreas metropolitanas é acompanhada por uma expansão periférica, que inclui a criação de direitos industriais explícitos e implícitos, e pela concentração geográfica dos serviços de interesse coletivo.” (SANTOS, 2008, p. 85) 
A compreensão da especificidade do espaço metropolitano implica reconhecer que os seus elementos (meio ecológico, infraestruturas e sujeitos sociais) "apresentam uma interdependência estreita, sistemática e cotidiana, manifestada de forma concentrada em uma determinada fração do território que se encontra fragmentado pela divisão políticoadministrativa vigente". (LOPES, 2006, p. 139)

Em outras palavras, no território metropolitano, a escala de ocorrência de determinados fenômenos geográficos não encontra equivalência com a esfera de atuação dos governos locais. O fato metropolitano "se expressa assim pelo derramamento da espacialidade dos elementos do meio ecológico, das infra-estruturas, dos sistemas urbanos e dos próprios sujeitos sociais para além das fronteiras municipais, em um contexto geográfico de progressiva conurbação”. (LOPES, 2006, p. 139)

Azevedo e Mares Guia (2004) identificam três grandes fases evolutivas da questão metropolitana. A primeira, compreendida entre os anos de 1973 e 1988, caracterizou-se pela centralização da regulação e financiamento da política na União. ${ }^{103} \mathrm{~A}$ temática das regiões metropolitanas foi incluída na Constituição de 1967. Em 1973, com a promulgação da Lei Complementar Federal 14, foram criadas regiões em torno das principais capitais dos estados brasileiros: São Paulo, Belo Horizonte, Porto Alegre, Recife, Salvador, Curitiba, Belém e Fortaleza. (AZEVEDO; MARES GUIA, 2004, p. 106)

Uma crítica recorrente a esse processo foi a desconsideração das peculiaridades regionais de cada área metropolitana. A delimitação das áreas ocorreu com base na magnitude da população aglomerada e na extensão da área urbanizada sobre mais de um Município. Priorizou-se a racionalização econômica e funcional do espaço, consoante o planejamento econômico estabelecido pelo regime militar, em detrimento das especificidades locais e das dinâmicas então verificáveis de cooperação, consorciamento e articulação supramunicipal.

As estruturas de gestão eram prefixadas e hierárquicas, baseadas por completo nos executivos estaduais (conselhos deliberativos com ampla maioria estadual e conselhos

103 A partir de 1975, com a criação da Comissão Nacional de Política Urbana e Regiões Metropolitanas (CNPU) e do Fundo Nacional de Desenvolvimento (FNDU), os órgãos técnicos de planejamento metropolitano passam a ser utilizados como repassadores de recursos do governo federal para os municípios situados nestas áreas e para os órgãos setoriais da esfera estadual que nelas atuavam. (AZEVEDO e MARES GUIA, 2000, p. 108) 
consultivos com participação municipal, mas encarregados apenas da realização de sugestões).

A segunda fase foi marcada pelo chamado neolocalismo pós-Constituição de 1988, momento em que uma retórica municipalista exacerbada enfraqueceu substancialmente o ímpeto metropolitano. (AZEVEDO; MARES GUIA, 2004, p. 106)

De fato, a Constituição Federal de 1988 e as Constituições estaduais em geral, recém-criadas, não avançaram na incorporação da gestão do território como variável importante em seus respectivos espaços.

Segundo Souza (2004, p. 70-71), o visível mal-estar dos constituintes para com a construção jurídica das regiões metropolitanas não é difícil de ser compreendido. Criadas em 1967 pelo regime militar, as regiões metropolitanas sempre estiveram associadas aos objetivos de centralização e controle do território que marcaram os anos de autoritarismo. A dependência dos recursos e de decisões federais, bem como o formato de gestão que limitava a participação dos Municípios integrantes, redundou em estruturas de gestão pouco pluralistas e centralizadoras.

Não espanta a opção do constituinte de 1988 de manter as regiões metropolitanas como instâncias meramente administrativas, ausente qualquer capacidade política, notadamente em face de um contexto em que os Municípios ampliaram significativamente seu grau de autonomia.

Impelidos pelas demandas por formatos mais democráticos e descentralizados de gestão pública, os constituintes silenciaram sobre as questões relativas à gestão dos espaços metropolitanos, fato que explica, em parte, o enfraquecimento da maioria das entidades metropolitanas até então existentes. (SOUZA, 2004, p. 71)

A terceira fase relativa à evolução das regiões metropolitanas iniciou-se em meados da década de 1990, período em que foram celebradas parcerias entre Municípios metropolitanos, bem como teve início um incipiente processo de formação de redes nacionais e de grupos e agências de vocação urbana (associações compulsórias supramunicipais - gestão de bacias hidrográficas - e modalidades voluntárias de associativismo metropolitano). (AZEVEDO; MARES GUIA, 2004, p. 106)

Nessa terceira fase, Lopes (2006, p. 148) informa que o enfraquecimento das antigas entidades metropolitanas das décadas de 1970 e 1980 e a ausência da força coercitiva simétrica federal que as sustentava permitiram o surgimento de renovadas 
formas de gestão metropolitana. Dois conjuntos distintos de experiências metropolitanas passaram a conviver: sistemas de gestão remanescentes do passado, marcados por uma forte presença do Estado-Membro e, do lado oposto, experiências marcadas por um "protagonismo voluntarista", sobretudo dos Municípios, pautadas por maior flexibilidade, fazendo uso de mecanismos organizativos e operacionais renovados e livres das heranças e forças de inércia institucionais do passado.

Esse "voluntarismo sem modelo" para a gestão metropolitana indica que não existia um formato institucional definitivo para tais regiões, conclusão que favoreceu a construção de sistemas mais condizentes com as necessidades de cada área.

Em todos os casos, enormes dificuldades institucionais se apresentaram. Elas se originaram, em parte, dos problemas em mobilizar a sociedade e os atores públicos implicados na vivência metropolitana.

Do lado da sociedade civil, Azevedo e Mares Guia (2004, p. 107) bem colocam que transformações institucionais não acarretam a fruição imediata de bens e serviços públicos. O caráter gradual, fragmentado e usualmente lento dos benefícios oriundos dos aprimoramentos institucionais no espaço metropolitano faz com que a pauta institucional perca importância relativa diante de problemas mais prementes relacionados à saúde, segurança pública e outros, sentidos de forma mais direta pela população. Os avanços institucionais das regiões metropolitanas não se encontram, portanto, na pauta de prioridades das organizações civis em geral.

Governos estaduais e Municípios metropolitanos, embora reconheçam a importância da questão institucional metropolitana, tendem a vê-la como um "jogo de soma zero", em que o aprimoramento da governança metropolitana pode resultar na redução do poder estadual ou municipal. A despeito da retórica em prol dos aprimoramentos institucionais da região metropolitana, as agências estaduais e os Municípios maiores tendem ao conservadorismo diante de propostas de mudanças de contexto, em virtude das incertezas envolvidas e das prováveis perdas de posições políticas. (AZEVEDO; MARES GUIA, 2004, p. 107)

Cresce, nesse contexto, a importância dos "incentivos seletivos" (linhas de créditos subsidiadas, repasse de verba a fundo perdido, etc.) oferecidos pela União ou por governos estaduais para engajamento dos interessados nos desafios metropolitanos. (AZEVEDO; MARES GUIA, 2004, p. 107) 
Lopes (2006, p. 142) evidencia ainda que, na gestão metropolitana, cada sistema urbano tende a apresentar lógica própria, manifestada por uma expressão técnica e funcional peculiar e por exigências administrativas, operacionais e financeiras específicas.

Assim é que os sistemas hidrossanitários (drenagem pluvial, abastecimento de água, esgotos) são influenciados pelo desenho das bacias hidrográficas, enquanto os sistemas de transportes são pautados pelos desejos de viagem dos usuários ou, em outras palavras, pelas bacias de origem e destino que irão definir os itinerários das linhas. Sistemas de saneamento ou transporte tendem a ser financiados pelos usuários. Já a pavimentação das ruas ou a prestação de serviços de saúde, por exemplo, dependem do planejamento orçamentário. Digno de menção é o fato de que cada serviço urbano incide sobre grupos próprios de beneficiários, segmentados por características etárias e econômicas peculiares. (LOPES, 2006, p. 142-143)

Gouvêa (2005, p. 137) chama a atenção, também, para o fato de que um aspecto significativo dos problemas institucionais metropolitanos envolve a criação de fontes de financiamento para as políticas regionais.

A reticência dos Municípios maiores em comprometer-se com os processos de integração metropolitanos reside no risco de aporte de mais recursos que as demais municipalidades, sem uma adequada contrapartida em termos de participação proporcional nos processos de tomada de decisão referentes à alocação de tais valores, em um claro contexto de custos financeiros maiores do que os possíveis retornos políticos. (GOUVÊA, 2005, p. 138)

Em suma, no mesmo ambiente metropolitano conviverão múltiplas exigências de organização e expertise operacional, a depender do serviço em apreço, sem mencionar as inúmeras dificuldades políticas existentes, circunstâncias que tornam ainda mais complexa a estruturação institucional das áreas analisadas. 


\subsubsection{Em busca de premissas jurídicas a respeito do regime das regiões metropolitanas}

A maior flexibilidade a respeito da gestão metropolitana verificada nos últimos anos não equivale à afirmação de que inexistem parâmetros jurídicos mínimos para sua instituição e funcionamento.

É claro que a enunciação de diretrizes jurídicas não solucionará todos os problemas e desafios institucionais encontráveis nas regiões metropolitanas, tampouco esgotará os possíveis modelos de gestão cabíveis nessas áreas.

Souza (2004, p. 68) pondera, com acerto, que o entendimento sobre como os mecanismos informais de resoluções de conflitos entre atores públicos e privados pode se tornar mais importante para a análise das relações intergovernamentais presentes nos arranjos metropolitanos do que a investigação dos modelos administrativos e legais a que se submetem essas figuras. Isso porque a resolução de problemas e conflitos nessa seara segue estruturas e processos muitas vezes circunstanciais, que resultam em padrões extraconstitucionais e extralegais de articulação.

Trata-se de uma característica das trocas negociadas entre sistemas de governança em diferentes níveis institucionais que tendem a abolir ou reduzir comandos hierárquicos e formas de controle tradicionais. (SOUZA, 2004, p. 68, nota 6)

Após estudar os custos de transação presentes na gestão do consócio do Grande ABC e da Região Metropolitana de Belo Horizonte, Machado (2007, p. 105) conclui pela precariedade dos arranjos institucionais federativos no Brasil. Para o autor, os atores públicos, as afinidades políticas e o poder econômico exercem um papel mais importante na redução de custos de transação do que as instituições formalmente constituídas.

Em que pese a aceitação dos limites funcionais e operacionais das instituições juridicamente estabelecidas para o trato da questão metropolitana, a descrição dos ditames jurídicos se prestará à consecução dos fins propostos para esta pesquisa, que não almeja a análise crítica das regiões metropolitanas, mas o enquadramento geral do saneamento nesse contexto.

Os contornos jurídicos das regiões metropolitanas dados pela Constituição de 1988 são poucos e sucintos. Segundo o disposto no art. 25 do Texto Maior, a região 
metropolitana supõe: (i) um agrupamento de Municípios limítrofes; (ii) a identificação de funções públicas de interesse comum aos Municípios integrantes do agrupamento; (iii) e o imperativo de organização, o planejamento e execução das funções públicas de interesse comum. O contexto metropolitano é, como se sabe, reconhecido e instaurado por lei complementar estadual.

Além dos indicativos constitucionais, foram adotados como linha de desenvolvimento do raciocínio alguns dos subsídios teóricos obtidos quando da análise da titularidade dos serviços de saneamento no contexto das regiões metropolitanas.

Demonstrou-se que a ampla maioria dos posicionamentos jurisprudenciais encara como imprescindíveis a participação dos Municípios nas decisões e processos metropolitanos para que se assegure a validade e legitimidade da gestão metropolitana.

A afirmação de que a participação dos Municípios é necessária não resulta em uma garantia de eficiência de gestão da área metropolitana. Ao contrário, o elevado número de atores pode tornar extremamente difícil a definição e concretização das políticas públicas comuns.

Exemplo pode ser encontrado na região metropolitana de Belo Horizonte, conformada, na perspectiva administrativa, por uma assembleia metropolitana - Ambel (composta pelo Estado e pelos Municípios metropolitanos), que dita os parâmetros de atuação de uma agência de desenvolvimento metropolitano (entidade autárquica).

Para Azevedo e Mares Guia (2000, p. 120) a Ambel (Assembleia Metropolitana de Belo Horizonte) tem-se mostrado, em muitos aspectos, incapaz de processar as diferentes reivindicações de âmbito regional dos Municípios. Não existe uma consciência metropolitana entre boa parte dos membros da Ambel. Prevalece uma visão tradicional de cunho local que cria obstáculos à organização regional. Parte dos problemas advém do fato de as direções da Ambel terem sido, desde sua implantação, controladas por alianças dos pequenos Municípios, em franca oposição aos Municípios maiores: Belo Horizonte, Betim, Contagem.

Machado (2007, p. 95) apresenta o argumento de que, em alguns casos, a assimetria de forças (desequilíbrio de poderes entre os atores e organizações presentes na região metropolitana) pode favorecer a obtenção de melhores resultados gerenciais:

Se seguirmos, sem contestação, a premissa presente na teoria geral do federalismo de que quanto maior a assimetria de forças entre entes federados, maiores as dificuldades para a cooperação intergovernamental, somos levados a 
supor que as condições gerais, para a articulação entre municípios no Grande $\mathrm{ABC}$, são mais propícias que na $\mathrm{RMBH}$, pelo menos sob a perspectiva da simetria dos atores.

Para nossa surpresa, essa premissa se confirma em parte, mas não é absoluta, pois ocorreram vários momentos em ambas as experiências que uma maior assimetria dos atores favoreceu as transações metropolitanas. Isso ocorreu notoriamente no modelo vertical da RMBH, mas houve situação semelhante no Grande ABC: o consórcio se robusteceu justamente quando um ator mais assimétrico, no caso, o governo do estado, passou a participar da articulação regional.

As dificuldades da coordenação dos interesses metropolitanos podem ser mitigadas com a participação do Estado na gestão da região metropolitana, fato que, em muitas casos, funciona como um elemento estabilizador, capaz proporcionar maior eficiência no desenvolvimento de políticas públicas regionais.

Outras posturas institucionais favoreceriam o relacionamento dos atores metropolitanos. Incentivos políticos e econômicos (como linhas de financiamento subsidiadas) são mecanismos relevantes para a obtenção do compromisso de atuação concertada dos entes envolvidos.

A subdivisão das regiões metropolitanas em regiões administrativas de menor abrangência uniria um menor número de Municípios em torno de assuntos que lhes são mais próximos e prementes. Nesse desenho, os Municípios opinariam apenas sobre a gestão de serviços comuns efetivamente a eles relacionados. Com efeito, alguns serviços não concernirão necessariamente a todos os Municípios metropolitanos, sendo aconselhável que sua gestão se faça apenas pelas unidades políticas por eles atingidos.

Essas múltiplas subdivisões administrativas se reuniriam para fins decisórios apenas quando temas que dissessem respeito a toda a região metropolitanas estivessem em pauta.

Admite-se, ainda, que Municípios de maior envergadura ou responsáveis por atribuições ou investimentos de maior volume possam emitir votos qualificados quando decididas questões de interesse metropolitano. Isso, certamente, redundaria em maior disposição política no trato das questões metropolitanas.

Os interesses federativos, organizados em torno do fato metropolitano, devem ser congregados na forma de uma unidade decisória ou administrativa definida pela lei complementar estadual. 
Muito se discute a respeito da natureza dessa unidade administrativa. Meirelles (2008, p. 84) destaca alguns de seus caracteres primordiais. O primeiro é que a região metropolitana não se erige em entidade estatal intermediária entre o Estado e os Municípios. Não se trata, portanto, de uma nova entidade política, mas uma área de serviços especiais, de natureza administrativa.

Dentre as figuras cabíveis na administração da região metropolitana, enumera o autor a possibilidade de criação de entidade autárquica (autarquia) ou estatal (empresa pública, sociedade de economia mista) ou a atribuição de tal responsabilidade a órgão do Estado (Secretaria de Estado), ou a um colegiado de representantes dos Estados e Municípios (Comissão e Conselho). (MEIRELLES, 2008, p. 84)

Em que pese a relevância das sugestões de Meirelles, diante das premissas teóricas ora utilizadas como fundamento para a compreensão das regiões metropolitanas, a atribuição de sua gestão a órgão ou entidade exclusivamente estadual não deve ser compreendida como possível no presente cenário jurídico.

É fundamental a instituição de órgão, conselho ou entidade que congregue os Municípios atingidos e lhes possibilite a participação nas decisões metropolitanas. É possível cogitar-se até da criação, pelo Estado, de entidades de desenvolvimento metropolitano de caráter autárquico ou de outra natureza, com o objetivo de atuar na execução de políticas públicas metropolitanas. Contudo, tal entidade deverá seguir as diretrizes e comandos traçados pela unidade administrativa que aglutine os entes federados atingidos pelo fato metropolitano.

Outro tema que merece considerações no trato das regiões metropolitanas envolve a definição das funções de interesse comum, cuja gestão integrada se apresenta como justificativa fundamental para a criação da referida área administrativa. São os serviços ou funções cuja organização ou efeitos são sentidos além do território de cada Município e que, justamente por isso, devem ser tratados em uma perspectiva regional.

No caso das regiões metropolitanas, encontram-se especialmente vinculadas ao fenômeno da conurbação, que exige planejamento urbano e desenvolvimento integrado de atividades essenciais.

Uma das notas características das funções de interesse comum reside na sua constante mutação. Determinada atividade considerada de interesse predominantemente 
local poderá, com o tempo e com as transformações sociais, passar à esfera de predominância regional.

Uma forma possível de qualificação do interesse comum pode ser a sua conceituação por exclusão: os interesses dos Municípios que não forem predominantemente locais serão de caráter comum ou regional.

Nesse sentido, há, na doutrina, parâmetros estabelecidos para a identificação da predominância do interesse local, critério utilizado para a delimitação da competência municipal sobre os serviços. Moreira Neto (2001, p. 245), cataloga as conclusões a respeito da existência do interesse local e seus critérios de delimitação:

\footnotetext{
1. predominância do local (Sampaio Dória)

2. interno às cidades e vilas (Black)

3. que se pode isolar (Bonnard)

4. territorialmente limitado ao município (Borsi)

5. sem repercussão externa ao município (Mouskheli)

6. próprio das relações de vizinhança (Jellinek)

7. simultaneamente oposto a regional e nacional (legal)

8. dinâmico (Dallari)
}

A contrario sensu, os serviços que não podem ser isolados no Município, que ultrapassem um único território e que apresentem repercussão externa à unidade local seriam considerados serviços de interesse comum. O importante é que tal qualificação siga as características concretas verificadas na região.

O Projeto de Lei n. 5296/2005, que continha a proposta original que resultou na Lei n. 11.445/07, apresentava uma clara tentativa de conceituação por exclusão de serviços regionais, então denominados serviços públicos de saneamento básico integrados. Embora o projeto não tenha sido aprovado tal como proposto, vale a pena recuperar algumas de suas determinações como fonte hermenêutica para identificação das funções de interesse comum no saneamento:

Art. $2^{\circ}$ Para os efeitos desta Lei, consideram-se: [...]

IX - serviços públicos de saneamento básico de interesse local:

a) o sistema de manejo de águas pluviais, ou a parcela dele que receba contribuições exclusivamente de um Município;

b) quando destinado a atender exclusivamente um Município, qualquer dos seguintes serviços:

1. a captação, a adução de água bruta ou tratada, o tratamento de água e a reservação para abastecimento público;

2. a interceptação e o transporte, o tratamento e a destinação final de esgotos sanitários; e 
3. o transbordo e transporte, o tratamento e a disposição final de resíduos sólidos urbanos;

c) em qualquer caso: a distribuição de água, a coleta de esgotos sanitários, a varrição, a capina, a limpeza e a poda de árvores em vias e logradouros públicos, a coleta e a triagem, para fins de reaproveitamento, reuso ou reciclagem, de resíduos sólidos urbanos e a microdrenagem;

$\mathrm{X}$ - serviços públicos de saneamento básico integrados: os serviços públicos de saneamento básico não qualificados como de interesse local; [...].

Note-se que nas letras "a" e "b" do dispositivo transcrito trazem um critério territorial para classificar como locais os serviços lá descritos (a letra "a" inclui, ainda, um critério de custeio econômico dos serviços, qual seja, a sustentação exclusiva dos serviços de manejo de águas pluviais por um Município). A letra "c", por sua vez, enumera serviços tidos como locais por definição ou natureza, provavelmente por pressupor o projeto que sua prestação seria sempre local. Seriam serviços integrados todos aqueles não qualificados como de interesse local (conceituação por exclusão).

A predominância do critério territorial para a delimitação dos serviços locais e integrados (podendo estes últimos ser aproximados conceitualmente das funções de interesse comum) não representa um indicativo definitivo da condição dos serviços. Em áreas conurbadas, sistemas de manejo pluvial mantidos por um único Município podem, por exemplo, atingir Municípios limítrofes.

No caso dos serviços ontologicamente considerados como locais (art. $2^{\text {o }}$, IX, “c”), admitem-se hipóteses em que apresentarão uma funcionalidade regional. A coleta de água, por exemplo, embora realizada no âmbito de determinado Município, pode ser essencial para os Municípios limítrofes desprovidos de mananciais. Nesses casos, o planejamento dos serviços deverá ter em conta o fator metropolitano. Tenha-se como exemplo a questão da outorga do uso de recursos hídricos nos mananciais de determinado Município, que deverá levar em consideração toda a demanda metropolitana atendida pelas fontes de água. A outorga do uso da água e sua respectiva captação deverão ser proporcionais a toda a esfera metropolitana atendida.

Segundo Gouvêa (2005, p. 137), tem sido comum, tal como originariamente proposto pelo Projeto de Lei n. 5296/2005, a separação dos serviços comuns em segmentos, alguns para serem tratados de forma unificada e outros para execução isolada pelos Municípios metropolitanos. Os defensores de modelos unificados de gestão 
metropolitana encaram como contraditória e incompreensível a segmentação dos serviços públicos de interesse comum (em busca de parcelas de serviços necessariamente locais).

Será improvável encontrar um critério definitivo para a delimitação dos serviços comuns. Apenas a dimensão concreta das funções determinará se sua estrutura deverá ser gerida de forma integrada pelos Municípios metropolitanos. O importante é que a lei complementar estadual, ao optar por enumerar expressamente as funções comuns, o faça com supedâneo na realidade metropolitana, a fim de que apenas os temas efetivamente regionais sejam tratadas de forma integrada.

\subsubsection{A interface entre a gestão associada e as regiões metropolitanas}

A história recente das regiões metropolitanas comprova que não se atingiu com plenitude um amadurecimento institucional que possa suplantar a tradicional e exacerbada concepção da autonomia municipal que muitas vezes se apresenta como obstáculo à consolidação desse modelo de gestão.

A aplicação de figuras consensuais de cooperação federativa na administração metropolitana tem sido vista como uma medida complementar que visa mitigar essas dificuldades.

Assim, nada impede que as unidades federadas abarcadas pela região metropolitana possam, consensualmente, fazer uso de institutos como o convênio de cooperação e os consórcios públicos para dar cabo das necessidades institucionais das áreas conurbadas.

Os acordos cooperativos poderão concernir a áreas ou temas específicos da gestão metropolitana, facilitando debates e tornando mais focada a atuação das entidades políticas.

A aplicação de formas acordadas de gestão pode reduzir as dificuldades de transação política uma vez que permitem a valorização de papel daqueles entes encarregados de maiores responsabilidades ou investimentos na consecução dos serviços comuns. 
Ademais, os instrumentos de gestão associada permitirão maior flexibilidade à gestão metropolitana, possibilitando a transferência de competências a terceiros que, do contrário, deveriam ser realizadas conjuntamente pelas unidades políticas abrangidas pela região metropolitana.

O tópico seguinte será dedicado à descrição de noções gerais sobre a gestão do saneamento nas regiões metropolitanas. Naturalmente, as implicações jurídicas decorrentes da Lei n. 11.445/2007 já discutidas no âmbito da gestão associada dos serviços públicos não serão aqui repetidas, estendendo-se, no que couber, às regiões metropolitanas.

\subsubsection{A estruturação dos serviços de saneamento nas regiões metropolitanas}

Estabelecidas as principais premissas jurídicas adotadas a respeito do funcionamento e da gestão das regiões metropolitanas, pode-se adentrar no desenho geral da prestação dos serviços de saneamento nesse contexto.

Muitos dos condicionantes jurídicos concernentes ao saneamento e seu regime foram explicitados no capítulo atinente à gestão associada. Nesse sentido, este tópico destina-se a uma rápida e concisa enumeração a respeito da estrutura dos serviços nas regiões metropolitanas e institutos congêneres.

A competência para regular, fiscalizar e organizar os serviços qualificados como funções de interesse comum pertence, naturalmente, ao conjunto de entes federativos implicados na gestão metropolitana. Poderão ser constituídas câmaras ou subdivisões administrativas para tratar de assuntos técnicos ou temas que não digam respeito à totalidade da área metropolitana. A unidade administrativa metropolitana emitirá as normas infralegais necessárias à prestação dos serviços. O conteúdo da regulação será o mesmo descrito no item 4.2.4 deste trabalho.

O planejamento dos serviços comuns de saneamento nas áreas metropolitanas será necessariamente desempenhado em conjunto pelos Municípios. Não se trata de mera opção dos entes federados, mas da necessidade inescapável derivada do contexto metropolitano. O conteúdo, os objetivos e as demais características dos planos de saneamento são os mesmos descritos no tópico 4.2.5 deste trabalho. 
A competência para outorgar concessão, permissão e autorização dos serviços de saneamento considerados como funções comuns, também, será do órgão ou entidade de caráter metropolitano. A concentração dessa competência na unidade administrativa metropolitana proporcionará os ganhos de escala territorial e econômica, bem como a centralização de gestão inerente e necessária ao desenvolvimento dessas atividades.

À semelhança do que foi constatado na gestão associada, a prestação dos serviços poderá assumir diversos formatos ou desenhos. Poderá ser delegada a sua prestação a um ou mais particulares, dependendo dos estudos econômicos e financeiros realizados.

A prestação direta pela unidade administrativa metropolitana pode ser considerada. Todavia, essa medida se apresenta um tanto improvável, pois exigiria a alocação no órgão ou entidade metropolitano(a) de elevados recursos humanos e materiais.

A transferência da prestação a órgão ou entidade estadual como empresas prestadores de serviços de saneamento apresenta-se, mais uma vez, como opção viável. Também nesse caso as diretrizes da Lei de Saneamento devem ser observadas, sendo imprescindível a formalização de contrato.

Defende-se, aqui, a ideia de que a outorga de serviços a empresa estadual sem licitação exigirá a formalização de convênio de cooperação e de contrato de programa, mesmo tratando-se de um contexto metropolitano, sob pena da impossibilidade da contratação direta da entidade.

\subsection{NOTAS SOBRE O FINANCIAMENTO DOS SERVIÇOS NA GESTÃO COMPARTILHADA: OS SUBSÍDIOS CRUZADOS}

Não há prestação de serviços públicos sem custo. Bem assim, as fontes de financiamento adquiriram justificada centralidade no arranjo organizativo dos serviços, tendo sido produzida uma profícua literatura jurídica e econômica para seu tratamento.

A Lei Nacional de Saneamento Básico oferece importante parâmetro interpretativo ao dispor: 
Art. 29. Os serviços públicos de saneamento básico terão a sustentabilidade econômico-financeira assegurada, sempre que possível, mediante remuneração pela cobrança dos serviços:

I - de abastecimento de água e esgotamento sanitário: preferencialmente na forma de tarifas e outros preços públicos, que poderão ser estabelecidos para cada um dos serviços ou para ambos conjuntamente;

II - de limpeza urbana e manejo de resíduos sólidos urbanos: taxas ou tarifas e outros preços públicos, em conformidade com o regime de prestação do serviço ou de suas atividades;

III - de manejo de águas pluviais urbanas: na forma de tributos, inclusive taxas, em conformidade com o regime de prestação do serviço ou de suas atividades. (Grifo nosso)

A expressão "sempre que possível" é reveladora da abertura que a lei reconhece ao custeio direto dos serviços de saneamento pelo Poder Público. Não existindo sustentabilidade econômico-financeira por meio da cobrança dos usuários, deverá o Poder Público arcar com os custos correspondentes.

Assim, as fontes de financiamento podem advir do Erário, sendo sua origem os recursos de impostos ou taxas coletados pelo Poder Público, e ainda da cobrança de tarifas dos usuários.

Este, com efeito, o desenho geral da remuneração dos serviços de saneamento básico: custeio por meio de receitas decorrentes de impostos, taxas ou tarifas.

Em todos os casos, a delegação dos serviços à iniciativa privada será também uma opção para a obtenção de recursos necessários aos elevados investimentos iniciais para implantação de infraestruturas. Aos particulares caberá à remuneração, diferida no tempo, do capital investido, por meio da cobrança de taxas ou tarifas, ou mesmo pelos pagamentos diretos realizados pelo poder concedente (no caso das concessões administrativas de que trata a Lei n. 11.079/04). A concessão de serviços públicos, em suas diversas modalidades, associada a outros mecanismos privados de contratualização, representa, assim, um importante instrumento para o fortalecimento dos meios de financiamento.

O cálculo e a estrutura da tarifa ou taxa têm forte conexão com a eficiência técnica e com os resultados sociais da prestação de serviços públicos.

Determinado regime de financiamento, por exemplo, pode exercer a função de incentivo à redução de custos e ao aprimoramento tecnológico, tudo isso em prol da modicidade do acesso ao serviço pelos usuários. ${ }^{104}$ Pode, ainda, favorecer a utilização

${ }^{104}$ Conforme informam Barbosa e Freitas (2008, p. 250), "na visão de Vasconcelos (2004), a modicidade tarifária é um dos requisitos exigidos para se ter a prestação de um serviço público adequado. Conforme o 
racional de bem essencial ao serviço (água) ou induzir condutas com reflexos benéficos para a coletividade como um todo (redução da produção de resíduos sólidos).

A política remuneratória dos serviços é, em essência, um instrumento de realização de políticas públicas. ${ }^{105}$

Nem sempre os objetivos buscados pela estrutura remuneratória dos serviços serão atingidos. Segundo Freitas e Barbosa (2008, p. 260), o modelo Planasa se valeu de uma estrutura que divide a tarifa em duas partes: a primeira, um valor fixo que embute uma franquia mensal de até $10 \mathrm{~m}^{3}$ de água, destinada a cobrir os custos fixos das empresas. A segunda parte da tarifa é utilizada como incentivo à racionalização do uso da água, pois seu valor cresce à medida que se eleva o consumo. Essa segunda parte da tarifa é aplicada, ainda, na prática do subsídio cruzado pelas empresas de saneamento.

Outras características comuns das tarifas do modelo Planasa são as seguintes: a) as tarifas residenciais são estabelecidas em blocos de consumo, cobrados com preços crescentes, no valor mínimo de $10 \mathrm{~m}^{3}$ por mês, para a conta mensal, na maioria das empresas; b) para os usuários de menor poder aquisitivo existe uma tarifa subsidiada, de forma indireta, comumente denominada "social"; c) as tarifas comercial e industrial são estabelecidas em blocos e cobradas a preços crescentes, com valores superiores às tarifas residenciais, mantendo-se a estrutura estabelecida na década de 1970; e d) para as tarifas

\footnotetext{
autor considera, as tarifas serão módicas quando não impedirem que as classes mais necessitadas da prestação do serviço tenham acesso a ele. O serviço adequado, por sua vez, foi definido na Lei de Concessões $\left(\S 1^{\circ}\right.$ do art. $\left.6^{\circ}\right)$ como "aquele que satisfaz as condições de regularidade, continuidade, eficiência, segurança, atualidade, generalidade, cortesia na sua prestação e modicidade tarifária. Nesse contexto, uma tarifa módica pode ser entendida como aquela que viabiliza os serviços prestados por empresas que trabalham com custos eficientes e realizam investimentos prudentes". (Grifo nosso)

${ }^{105}$ Ainda a respeito dos efeitos da medição e cobrança pelo consumo nos serviços de água e esgoto avalie-se a posição de Turolla (1999, p. 7-8): "Neste último particular, a maioria das estimativas mostra que a cobrança de acordo com o consumo reduz de maneira significativa o volume consumido, em relação às formas de cobrança não relacionadas com o volume de água consumido. Mesmo considerando-se os elevados custos envolvidos na infra-estrutura de medição, é geralmente apontada a superioridade em termos de custo-benefício desta alternativa. Extrapolando a análise de custo-benefício, duas outras razões importantes para a medição são 1) o caráter escasso do recurso água disponível para abastecimento urbano e 2) a redução no volume de esgotos gerado a partir da redução no consumo de água, com impacto sobre o custo daquele serviço. Um terceiro argumento diz respeito ao tratamento eqüitativo dos consumidores de água: se, em um sistema não medido, segundo TAYLOR (1994), a tarifa reflete o consumo do usuário médio, os consumidores mais pobres, que consomem menos água, serão penalizados. Entretanto, esta última dificuldade normalmente é superada em alguns países sem o recurso ao sistema medido, pela tarifação de acordo com critérios do valor, área construída ou padrão de construção da propriedade servida, permitindo captar diferenças de classe social e de padrão de consumo de água entre os consumidores. Um argumento contrário à medição é apresentado por TAYLOR (1994): a possibilidade de que alguns consumidores usem menos água que o desejado, levando a problemas de saúde e ainda gerando o risco de disseminação de doenças infecciosas. O mesmo autor considera que um sistema de tarifação medido em que uma permissão mínima de consumo seja fornecida gratuitamente e de maneira garantida aos usuários anularia esses contra-argumentos à medição."
} 
de esgoto há uma grande diferenciação de critérios, mas predomina a utilização de um percentual fixo sobre a conta de água, de 100\%, na maioria das vezes (2008, p. 260).

Para as citadas autoras, as características da estrutura tarifária adotada pelas companhias estaduais de saneamento apresentam efeitos senão perniciosos, sujeitos a inúmeras críticas (FREITAS; BARBOSA, 2008, p. 261-262):

(i) com relação às diferenças de preços do metro cúbico da água, a depender do uso a ser dado ao bem (comercial, residencial, etc.): não há razões para acreditar que o custo do fornecimento de um metro cúbico de água para uso comercial seja tão distinto do custo de fornecimento para uma residência ou repartição pública;

(ii) com relação à cobrança da tarifa de esgoto com base em um percentual da tarifa de água: os custos para coleta e tratamento de esgoto são, com efeito, distintos dos custos para coleta e distribuição de água, tornando a aplicação do referido percentual desprovida de aderência à realidade econômica dos serviços;

(iii) quanto à tarifação crescente em blocos de consumo: não surte, necessariamente, o efeito desejado de contenção do uso da água, uma vez que não consegue individualizar o consumo de usuários situados em prédios ou condomínios. Tampouco o consumo elevado de água indicará com certeza absoluta um elevado padrão de vida do usuário. Um consumo maior de água pode indicar, na verdade, uma família mais numerosa;

(iv) no que toca à tarifa mínima cobrada, prejudica os usuários que consomem menos água. Em outro aspecto, a receita extra gerada pela tarifação mínima acaba reduzindo o preço do metro cúbico de água para as situações de consumo elevado, induzindo os grandes consumidores a maiores gastos de água.

Independentemente dos desvios constatados na política tarifária, o importante é ter em mente que o acesso a serviços públicos de caráter econômico depende, em parte, da interação eficiente dos modelos de financiamento. A universalização dos serviços pode ser consideravelmente incrementada com o apoio de uma política de investimentos calcada em sistemas autossustentáveis ou conscientemente apoiados por recursos destinados a esse fim pelo setor público.

Bem por isso, o tema dos subsídios nos serviços de saneamento será tratado neste tópico. 
De fato, os subsídios, especialmente o subsídios cruzados, constituem uma das principais justificativas econômicas da gestão compartilhada. Assim, embora muitas outras questões possam ser trazidas à tona a respeito do financiamento dos serviços de saneamento (como a discussão em torno da aplicação de taxas ou tarifas em algumas atividades $^{106}$ ou o estudo dos mecanismos de aporte direto de recursos públicos nos serviços como o contrato de rateio ou a criação de fundos metropolitanos), será conferida prioridade ao tema dos subsídios cruzados.

Usualmente, como dito acima, espera-se que a estrutura tarifária promova a eficiência econômica no uso dos recursos envolvidos na prestação dos serviços e assegure o equilíbrio financeiro dos prestadores. Ocorre que justamente as tarifas que possibilitam a consecução desses objetivos, por seu valor maior, podem se apresentar como de difícil acesso a usuários de menor renda. (MONTEIRO, 2008, p. 314)

Bem por isso, os subsídios são prática comum nos serviços públicos. Deles depende o acesso aos serviços por usuários menos favorecidos. Nesse sentido, os subsídios ligam-se à noção de universalização dos serviços e à distribuição de renda. Não é demais asseverar, portanto, que gratuidades e tarifas módicas não são uma mera liberalidade do poder público ou do prestador, mas fruto de uma específica organização econômica que, em muitos casos, possibilita que determinadas classes ou segmentos sociais sejam oneradas em menor proporção que setores mais abastados da sociedade.

A Lei Nacional de Saneamento assim definiu os subsídios aos serviços:

Art. 31. Os subsídios necessários ao atendimento de usuários e localidades de baixa renda serão, dependendo das características dos beneficiários e da origem dos recursos:

I - diretos, quando destinados a usuários determinados, ou indiretos, quando destinados ao prestador dos serviços;

II - tarifários, quando integrarem a estrutura tarifária, ou fiscais, quando decorrerem da alocação de recursos orçamentários, inclusive por meio de subvenções;

III - internos a cada titular ou entre localidades, nas hipóteses de gestão associada e de prestação regional.

\footnotetext{
${ }^{106}$ A doutrina há muito discute a aplicação das taxas e tarifas na remuneração dos serviços públicos. A questão não é nova. Discute-se a relação entre os meios remuneratórios descritos no art. 29 da Lei Nacional de Saneamento e as qualidades estruturais dos serviços de saneamento (compulsoriedade, divisibilidade, etc.). O caráter compulsório de alguns dos serviços de saneamento (água e esgoto, coleta de resíduos, etc.) foi largamente utilizado como critério definidor da taxa como seu meio de pagamento principal. Recentemente, tanto os tribunais quanto administrativistas de renome vêm relativizando esse posicionamento.
} 
Peixoto (2009, p. 503) esclarece as dimensões e abrangência das diferentes formas de subsídios:

(i) subvenção ou subsídio público, mediante realização de investimentos, transferências financeiras para o prestador do serviço ou pagamento direto aos usuários, com recursos fiscais provenientes do orçamento ou de fundos públicos, cuja origem não tenha vinculação específica com o serviço prestado;

(ii) subsídio tarifário interno, que se processa no sistema e na estrutura de cobrança de uma ou mais espécies de serviços prestados numa localidade ou região;

(iii) subsídio tarifário cruzado externo, que se processa no sistema e na estrutura de cobrança de uma ou mais espécies de serviços, prestados em mais de uma localidade submetida à gestão associada, em que haja transferência de subsídios entre localidades ou entre serviços, inclusive por meio de fundo de universalização.

Também clarificadoras as colocações de Monteiro (2008, p. 323), que distingue na literatura econômica os seguintes mecanismos de subsídios:

(i) quanto ao sujeito (subsídio à oferta e à demanda);

(ii) quanto ao objeto (subsidio à conexão e ao consumo); e

(iii) quanto à forma (subsídios diretos e cruzados).

O subsídio cruzado consiste, como visto, na transferência de recursos obtidos em determinado segmento social para outro que apresente maior vulnerabilidade, a fim de que este possa pagar preços públicos mais baixos. Os subsídios entre localidades ou tarifários externos são aqueles mais relevantes para esta discussão.

A prática de subsídios nem sempre é vista como algo positivo. Embora não se coloque contra tal medida, Coutinho (2002, p. 83) bem sintetiza os problemas que podem advir desse mecanismo:

\footnotetext{
Admite-se, desde logo, que essa idéia implica muitos problemas, de diferentes naturezas. Sabe-se que, do ponto de vista econômico, a prática de subsídios cruzados gera ineficiências indesejáveis. Já, do ponto de vista jurídico, a cobrança diferenciada de taxas traz à tona, por exemplo, uma complexa discussão a respeito dos princípios da igualdade e isonomia. As conseqüências tributárias a respeito de um mecanismo de taxação redistributiva também podem dar margem a argüições de inconstitucionalidade e ilegalidade de varias espécies.
}

Especificamente com relação aos subsídios cruzados, muitas críticas sobre seus efeitos econômicos podem ser enumeradas. Segundo Monteiro (2008, p. 324), a premissa 
conceitual subjacente à estrutura de subsídio cruzado se situa no baixo valor da elasticidade-preço da demanda dos serviços de saneamento. Contudo, ainda de acordo com o autor, pesquisas recentes contrariam essa premissa, uma vez que demonstram maior sensibilidade dos usuários de renda mais elevada às variações do preço do saneamento. Como conclusão, o aumento do volume faturado perante usuários beneficiados pelos subsídios pode não ser capaz de compensar a redução do volume faturado frente aos usuários de maior poderio econômico, onerados pelo sobrepreço tarifário.

O sobrepreço em relação a determinadas categorias de usuários ou localidades altera as denominadas medidas de excedente do consumidor e, em consequência, modifica o nível de bem-estar social associado às categorias de usuários abrangidas pela política de subsídios. Sob tal perspectiva, a aceitação da política de subsídios dependeria de uma análise conjunta de perdas e ganhos para os diferentes usuários, globalmente considerados, buscando-se o exame dos resultados dos subsídios para toda a sociedade. (MONTEIRO, 2008, p. 325)

Outros problemas associadas aos subsídios cruzados podem ser sintetizados nos seguintes termos, com base nos ensinamentos de Monteiro (2008, p. 325): menor atratividade dos investimentos em expansão para atendimento de populações mais vulneráveis; menor capacidade financeira do prestador de serviços de saneamento para investir em expansão voltada para o atendimento de usuários não beneficiados pelos subsídios; possibilidade de que os usuários beneficiados pelos subsídios sejam incentivados a aumentar o consumo e, por conseqüência, o desperdício do bem oferecido pelo serviço público e o fato de que as tarifas subsidiadas reduzidas podem representar um baixo incentivo para a cobrança dos valores devidos pelos usuários.

Não é objetivo aqui atacar ou defender os subsídios cruzados, mas apenas fazer uma análise realista de suas potencialidades e problemas efetivos.

Ao menos do ponto de vista jurídico, as afirmações de quebra da igualdade e da isonomia entre os usuários em razão da política de subsídios podem ser contornadas com o notório ensinamento de que a igualdade se realiza por meio da observância e adaptação dos serviços às diferenças entre os destinatários da prestação. A máxima "tratar desigualmente os desiguais" é uma realidade inescapável nos serviços públicos.

Acrescente-se que não é viável a aplicação absoluta do princípio da igualdade ou a radicalização dos fundamentos econômicos do equilíbrio de mercado (mediante o 
oferecimento do saneamento apenas aos usuários capazes de pagar), pois relativizadas essas balizas pelo princípio da universalização dos serviços e pelo fato de que o saneamento é essencial à saúde e ao desenvolvimento humano não podendo ser simplesmente negado às camadas mais carentes da população.

Assim, a diferenciação da tarifa por tipo de usuário, em adequação à respectiva capacidade de pagamento, pode ser considerada forma legítima de política pública. (SALOMÃO FILHO, 2002, p. 44)

As inúmeras externalidades positivas ligadas à otimização dos serviços (melhoria da saúde e meio ambiente, por exemplo) compensariam os problemas jurídicos e a redução na eficiência alocativa dos serviços.

Câmara (2005, p. 107) leciona que, isoladamente considerada, a prática do subsídio cruzado representa uma distorção dos elementos econômicos envolvidos na prestação do serviço público, pois a remuneração cobrada em cada segmento social envolvido é alterada artificialmente. Todavia, bem pondera o autor que esse instrumento não pode ser considerado, sozinho, uma providência benéfica ou nociva ao interesse público. Seu emprego dependerá das circunstâncias específicas de prestação do serviço público.

Ademais, é improvável estabelecer, a priori, a eficiência e a eficácia de uma política de subsídios diante da complexidade de seu funcionamento e das limitações dos instrumentos de avaliação dos resultados, constatações que demandam experimentações e maturação em longo prazo. (PEIXOTO, 2009, p. 503)

Subsídios cruzados explícitos, ${ }^{107}$ pela sua maior transparência, podem reduzir parte dos problemas acima destacados, já que evidenciam a medida do benefício concedido e os efetivos destinatários do apoio econômico. Com efeito, uma das razões para o sucesso das políticas de subsídios consiste na focalização daqueles que realmente necessitem do suporte financeiro. A identificação do público-alvo dos benefícios proporciona maior precisão e eficiência às políticas públicas.

Tomadas tais precauções, a política de subsídios cruzados pode ser utilizada como relevante instrumento de universalização do saneamento.

\footnotetext{
${ }^{107}$ Nos subsídios explícitos são estabelecidos os custos dos serviços, a tarifa real necessária à sua cobertura, após o que se estabelecem de forma transparente os subsídios e sobrepreços que irão sustentar a prestação.
} 


\section{CONCLUSÃO}

A concretização dos serviços de saneamento básico apresenta especificidades que tornam seu regime um capítulo à parte quando comparados com os demais serviços públicos. Tratando-se da gestão dos serviços de saneamento que envolvam múltiplas unidades federadas, tais especificidades se avolumam, justificando análises jurídicas próprias objeto da presente síntese.

Síntese conclusiva do capítulo 1 - o objetivo principal com esse capítulo foi proporcionar a contextualização teórica dos serviços de saneamento básico. Ou seja, a demonstração de seu posicionamento na noção mais ampla de serviços públicos e a compreensão do papel do regime jurídico dos serviços frente aos demais sistemas sociais.

1. A evolução histórica dos serviços de saneamento favoreceu sua gestão concentrada nos entes federativos de maior abrangência, União e Estados. Os Municípios, em sua maioria de porte pequeno ou médio, não possuíam condições econômicas ou técnicas para o desempenho dos serviços. Esse arranjo institucional logrou obter avanços significativos na universalização do saneamento, especialmente no fornecimento de água. Contudo, o papel secundário vivido pelos Municípios contribuiu para sua exclusão dos processos decisórios atinentes ao saneamento, resultando na propagação de um modelo que dava pouca atenção às especificidades e anseios locais (baixa participação popular).

2. A evolução do Planasa e as condições econômicas adversas da década de 1980 culminaram na insuficiência do modelo então prevalente de gestão do saneamento. Como em toda política pública, a dependência do passado se faz sentir no saneamento. A histórica exclusão dos Municípios redunda em um presente em que a ausência de expertise técnica e a contínua insuficiência econômica de muitos dos entes locais naturalmente impelem a gestão do saneamento a modelos concertados de prestação, em que o apoio das unidades políticas de maior abrangência é de extrema relevância para a sustentabilidade e sucesso da prestação.

3. A noção de serviço público sofre, como poucas no Direito Administrativo, pressões transformadoras. Tais transformações levam muitos autores a questionar a validade e importância prática do serviço público como conceito jurídico. No entanto, essa 
noção subsiste, ainda, como unidade aglutinadora de sentido no âmbito do regime de direito público. Importante para proporcionar as primeiras aproximações, a construção de uma noção de serviço público dificilmente será universal e absoluta e não prescinde da análise específica do regime jurídico de cada atividade. O saneamento, como espécie de serviço público, apresenta as principais características dessa figura: titularidade pública, regime jurídico predominantemente público e atendimento a uma necessidade de interesse coletivo. Do ponto de vista estrutural, o fato de que algumas das atividades integrantes do saneamento possuem caráter uti universi e se apresentam como serviços de fruição quase obrigatória não desvirtuam sua faceta fundamental como serviços públicos de viés econômico.

4. O saneamento se sujeita a muitos dos dilemas e vicissitudes sofridos pelo instituto dos serviços públicos. As mais significativas interferências ocorrem em virtude das pressões econômicas e políticas incidentes sobre a prestação. $\mathrm{Na}$ perspectiva econômica, a superação da escassez de recursos e a maximização de bem-estar são os pontos principais de pressão. Na perspectiva política, a tomada de decisões coletivas e adoção de programas finalísticos são as áreas de atrito que afetam os serviços públicos. Nesse contexto, o regime jurídico deve preservar sua especificidade e função no âmbito dos sistemas sociais. Sua tarefa consiste em criar expectativas normativas e zelar pelo seu cumprimento. Do ponto de vista institucional, o relativamente recente marco regulatório do saneamento dado pela Lei n. 11.445/2007 e as formas de gestão de serviços públicos trazidas pelo art. 241 da Constituição de 1988 e pela Lei n. 11.107/2005 representam importantes mecanismos jurídicos destinados a organizar, em torno da gestão compartilhada, a atuação de atores públicos e privados em prol da universalização dos serviços.

Síntese conclusiva do capítulo 2: o objetivo primordial com esse capítulo foi apresentar estruturalmente os serviços de saneamento, a fim de ressaltar os segmentos mais compatíveis com a gestão compartilhada dos serviços.

1. Os serviços de saneamento incluem ampla variedade de atividades que abrangem a captação, o transporte, o tratamento e a distribuição de água; a coleta, a interceptação, o transporte, o tratamento e a destinação final de dejetos líquidos; a coleta, o transporte e o processamento de dejetos sólidos e o manejo de águas pluviais. Seu regime 
jurídico é conformado não apenas pelas normas da Lei n. 11.445/07, mas por muitos e diferentes níveis de influência normativa oriundos do tratamento normativo dos sistemas de recursos hídricos, meio ambiente, dentre outros temas.

2. Os serviços popularmente conhecidos como serviços de água e esgoto são, por excelência, em rede. Podem configurar com grande facilidade um exemplo clássico de monopólio natural, em que a competição é inviável pela impossibilidade de duas redes de serviços distintas competindo pelo mesmo mercado.

3. Em função de suas características, tais atividades são, por excelência, o campo de atuação preponderante da gestão compartilhada, a permitir uma escala ideal de fornecimento. Recorde-se de que a desagregação de atividades nos serviços públicos e sua entrega a prestadores diferentes permitem a diversificação dos modelos de implantação de infraestrutura, oportunizando desenhos operacionais e econômicos mais flexíveis. Existem frações dos serviços que possuem caráter inequivocamente local, como a distribuição de água e a coleta do esgoto, caracterizadas por redes capilarizadas, diretamente conectadas aos prédios urbanos. Trata-se das atividades diretamente vinculadas aos usuários e que permitem seu acesso às utilidades públicas. Outros serviços, como a captação de água e a disposição final dos esgotos (associados ou não à infraestrutura de tratamento), podem ser desempenhados com maior eficiência em um contexto territorial mais abrangente, abarcando dois ou mais Municípios, seja porque tais atividades se situam no extremo oposto da cadeia de prestação (captação de água por atacado), demandando maior escala para sua viabilização, seja em razão das circunstâncias concretas de determinada localidade (notadamente características geográficas como a ausência de corpos hídricos em determinados Municípios para a captação de água ou a disposição final do esgoto tratado).

4. A operação de resíduos apresenta características mais próximas de um serviço comercial convencional. Desse modo, a configuração do monopólio natural é mais improvável na limpeza urbana e no manejo de resíduos sólidos. À semelhança do que ocorre com algumas das atividades dos serviços de água e esgoto, a limpeza urbana pode ser fracionada em atividades essencialmente locais, como a coleta de resíduos nos domicílios e varrição e limpeza de logradouros públicos, e outras em que uma abrangência regional pode ter influência significativa. Sistemas de transbordo e usinas de reciclagem, por demandarem um volume significativo de resíduos para seu funcionamento, poderiam ser organizados conjuntamente por Municípios interessados. Imperativos ambientais e 
mesmo geográficos (inexistência de áreas de aterro em determinados Municípios) podem também redundar na necessidade de atuação concatenada dos entes políticos.

5. Os sistemas pluviais apresentam um caráter essencialmente local, especialmente as estruturas de microdrenagem, o que enfraqueceria as razões para sua gestão compartilhada com outros entes federados. Entretanto, situações existirão em que a gestão compartilhada será aconselhável. Uma boa gestão das águas pluviais impacta na qualidade das águas dos rios urbanos, muitos dos quais perpassam o território de Municípios contíguos. A sobrecarga de vazão de água a jusante realizada pelo sistema de drenagem mal concebido por um Município pode afetar o território municipal a contíguo e conurbado, gerando enchentes e outros problemas, já que canais naturais de drenagem (rios e córregos), costumeiramente, são compartilhados pelas unidades políticas. Sobretudo em regiões metropolitanas, sistemas de drenagem de um Município interferem nas cidades limítrofes, impelindo o relacionamento dos entes federados para o bom desenvolvimento do saneamento pluvial por meio de mecanismos integrados de macrodrenagem.

Síntese conclusiva do capítulo 3: o objetivo primordial com este capítulo foi apresentar os fundamentos e principais condicionantes das relações de coordenação e cooperação entre entes federativos e sua influência no saneamento.

1. A cooperação entre entes federados integra a lógica de funcionamento do federalismo. Não obstante essa relação intrínseca, a cooperação federal evoluiu de maneira variável no tempo, dependendo das vicissitudes próprias de cada momento histórico.

2. No Brasil, embora se possa ser afirmar que o sistema federativo, quando implantado, encontrava respaldo em muitas das características concretas de nossa sociedade (situação federalista), o Estado Federado, em virtude de sucessivos governos autoritários, acabou assumindo uma faceta tradicionalmente centralizadora, com elevado grau de concentração de atribuições e recursos na União. Contribuiu enormemente para essa situação a baixa cultura democrática em nosso país, revitalizada apenas com o enfraquecimento e o fim do regime autoritário na década de 1980.

3. A Constituição de 1988 e suas reformas posteriores inauguraram novas possibilidades de relação institucional no Estado brasileiro, tornando mais concreta a alternativa da gestão compartilhada. $\mathrm{O}$ avanço tímido na cooperação federativa verificado nos primórdios do novo regime constitucional derivou de heranças passadas que, tanto na 
esfera política quanto na administrativa, ainda reconheciam a União como principal ponto de apoio para o desenvolvimento de políticas públicas.

4. Muitas são as são as razões econômico-gerenciais para a aplicação da gestão compartilhada: obtenção de economia de escala, resolução de obstáculos ambientais, resolução de obstáculos estruturais, etc. Processos de descentralização administrativa não resultam, necessariamente, em modelos positivos e eficazes de gestão. A transferência de responsabilidades a entes despreparados possui efeitos gerenciais pouco significativos. Fatos estruturais, institucionais e fatores ligados à ação política indicam que a gestão compartilhada dos serviços possui grande chance de obter bons resultados administrativos quando comparada à mera descentralização. Nesse contexto, a antítese estabelecida entre a centralização e descentralização da atividade administrativa perde força em razão das vantagens advindas da cooperação federativa.

5. Muito se desenvolveu no país no que toca à aproximação dos entes federativos, fato potencializado com o processo de democratização política e pela predisposição de muitos governos em empreender uma gestão mais descentralizada das questões públicas. O processo de amadurecimento das relações intergovernamentais aponta para um aprimoramento dos mecanismos de cooperação federal, de forma a superar a dicotomia estéril entre centralização e descentralização, uma dualidade que pouco acrescenta ao debate e à definição de novas formas de organização de serviços públicos de saneamento.

Síntese conclusiva do capítulo 4 - O objetivo fundamental com este capítulo envolveu a demonstração dos aspectos institucionais mais relevantes da gestão compartilhada, com destaque para os requisitos aplicáveis aos distintos modelos de relacionamento dados pela legislação que trata da gestão associada de serviços públicos e das regiões metropolitanas.

1. Um dos pressupostos para o exame da gestão compartilhada sob o aspecto institucional envolve a discussão sobre a titularidade do saneamento. Não há dúvidas a respeito da titularidade municipal do saneamento básico quando envolvidos serviços prestados no âmbito exclusivamente local. As discussões começam a surgir quando em jogo a prestação regional que implique dois ou mais Municípios. Nessas circunstâncias, as principais divergências são constatadas a respeito da titularidade dos serviços nas regiões 
metropolitanas. Foi possível identificar distintos posicionamentos doutrinários e jurisprudenciais sobre o tema, quais sejam: a defesa da titularidade municipal, a defesa da titularidade estadual e a defesa da titularidade compartilhada entre estados e Municípios. Fora das regiões metropolitanas, alguns poucos autores defendem a titularidade estadual ou federal dos serviços a depender da abrangência adotada para a prestação.

2. Após exame cuidadoso dos posicionamentos descritos, entende-se que aquele que melhor se adapta às características estruturais dos serviços e aos ditames constitucionais sobre o saneamento e as relações entre entes federados consiste na titularidade municipal dos serviços, fato que não elimina a necessidade de que, em situações como a das regiões metropolitanas, os Municípios necessariamente envolvidos se submetam às exigências e determinações regionais.

3. Definida a titularidade material a respeito do saneamento, a competência legislativa relacionada aos serviços resta clarificada. À União cabe a edição de diretrizes sobre o saneamento. Tais diretrizes vão além da definição de normas gerais, representando a edição de regras de organização prática dos serviços, possuindo, portanto, um sentido mais concreto. Ao contrário das normas gerais, as diretrizes não pressupõem particularização posterior, pois tendem a ser normas de aplicação direta, detentoras de um conteúdo programático e direcionado para a ação. Não se confundem com uma regulação abstrata ou principiológica, identificando-se com a necessidade de estruturar e operacionalizar o setor por meio da intervenção e do fomento.

4. Observadas as diretrizes traçadas pela União, a competência legislativa primordial a respeito do saneamento cabe aos Municípios, titulares dos serviços. Os Estados-Membros poderão editar normas de incentivo ao saneamento, notadamente a definição de regras de apoio à gestão associada. No caso das regiões metropolitanas, à competência dos Estados-membros acrescenta-se a de instituir, por meio de lei complementar, a unidade administrativa metropolitana e organizar a atuação conjunta dos entes federados por ela abrangidos.

5. Outras competências normativas afetam diretamente os serviços de saneamento. A disciplina do sistema de gestão das águas cabe à União nos termos do inciso IV do art. 22 da Constituição da República. A outorga do uso da água, controlada pela União e pelos Estados, dependendo da propriedade dos corpos hídricos (arts. 20 e 26 da Constituição), impacta diretamente os serviços de água e esgoto. O inciso VI do art. 24 
da Carta Constitucional informa que compete à União e aos Estados, concorrentemente, legislar sobre proteção do meio ambiente e controle da poluição. O Município não figura nesse rol. Somente pode legislar para "suplementar a legislação federal e estadual no que couber" (art. 30, II, da CF). A produção normativa nessas áreas temáticas pode interferir na delimitação da responsabilidade pelos resíduos e na definição da abrangência dos resíduos sólidos urbanos, alterando, portanto, o objeto do saneamento nos termos do art. $6^{\circ}$ da Lei n. $11.445 / 2007$.

6. A gestão associada de que trata o art. 241 representa um mecanismo voluntário de união de esforços para a gestão de serviços públicos. Consubstancia-se nas figuras do contrato de consórcio público, gerador de pessoa jurídica interfederativa, na forma autorizada por lei, e do convênio de cooperação.

7. A gestão associada não se confunde necessariamente com a definição de prestação regionalizada cristalizada no art. 14 da Lei n. 11.445/2007.

8. De forma geral, tanto a Lei n. 11.445/2007 quanto a Lei n. 11.107/2005 são extremamente flexíveis no que toca à transferência de competências do saneamento por meio da gestão associada. O art. $8^{\circ}$ da Lei Nacional de Saneamento prevê expressamente a delegação das atribuições de organização, regulação e fiscalização dos serviços. Tais funções poderão ser assumidas por consórcio público (com personalidade de direito público, no caso da regulação e fiscalização) ou por outro ente federado, no caso de convênio de cooperação.

9. Para alguns autores, a transferência do cerne das atividades de regulação por meio de convênio de cooperação não é possível, uma vez que se trata de competências indelegáveis. A Lei Nacional de Saneamento possibilita tal transferência, em parte, porque preserva aos titulares a elaboração dos planos de saneamento; em parte, porque mesmo a delegação de competências por convênio de cooperação não elimina a atuação conjugada dos entes federados, que supõe constante acompanhamento mútuo.

10. Segundo a Lei n. 11.445/2007, não é possível a delegação das funções de regulação para entidades fora dos limites do Estado. O intuito da lei foi asseverar o caráter regional que a regulação pode assumir no âmbito da gestão associada, conferindo, ainda, maior proximidade entre a atividade regulatória e as necessidades concretas dos serviços em cada região. 
11. Nos termos do art. 24 da Lei n. $11.445 / 07$, em caso de gestão associada ou prestação regionalizada dos serviços, os titulares poderão adotar os mesmos critérios econômicos, sociais e técnicos da regulação em toda a área de abrangência da associação ou da prestação. A padronização de determinações regulatórias no âmbito da gestão associada representa uma decorrência normal do exercício dessa função, desde que, é claro, a adoção dos mesmos critérios econômicos, sociais e técnicos no âmbito da associação ou prestação se apresente pertinente e viável no que toca à sustentabilidade dos serviços.

12. Considerando o perfil típico dos Municípios brasileiros, a tendência natural é a valorização da participação dos Estados na gestão associada. No caso de convênio de cooperação, é previsível que o Estado ou autarquia por ele constituída receba as atribuições de organização, regulação e fiscalização dos serviços. Também no caso dos consórcios, a participação do Estado como integrante da nova entidade criada também se revela um importante instrumento de desenvolvimento do saneamento, ao permitir que as entidades integrantes de sua administração possam ser alocadas na gestão dos serviços.

13. A competência para a elaboração dos planos de saneamento básico pertence exclusivamente aos titulares dos serviços, não podendo ser objeto de delegação. O plano se estabelece como norma do serviço e nessa qualidade deve ser obedecido por toda a Administração e pelos particulares que tenham se habilitado a prestá-lo por meio de institutos como o da concessão. O plano passa a ser o parâmetro para a elaboração de estudos técnicos e econômico-financeiros, definição dos planos de investimento e outras obrigações a serem formalizadas nos contratos de prestação dos serviços.

14. Na gestão associada, a competência para outorgar serviços de saneamento pode ser concentrada em um único ente federado ou em consórcio público. Em uma perspectiva regional, trata-se de uma importante função, pois permite que um mesmo prestador seja contratado para desempenhar os serviços em várias localidades, possibilitando a escala econômica eventualmente necessária para a sustentabilidade dos serviços.

15. A prestação dos serviços na gestão associada admite, também, diversas formulações. É possível cogitar: (i) da permanência da prerrogativa de prestar os serviços com seus respectivos titulares (enquanto a regulação e a fiscalização podem, por exemplo, ser delegadas para o Estado, sua entidade ou consórcio público); (ii) da transferência da prestação 
ao consórcio público por meio de contrato de programa; (iii) da transferência da prestação a órgão ou entidade da administração indireta de ente federado consorciado ou conveniado, também por contrato de programa; e, por fim, da (iv) delegação para a iniciativa privada, hipótese esta que pode ser concretizada pelo próprio titular ou por ente (ente federado, entidade da administração indireta ou consócio) a quem se tenha transferido competências adjudicatórias no âmbito de consórcio público ou convênio de cooperação.

16. $\mathrm{O}$ art. 10 da Lei Nacional de Saneamento informa que a prestação de serviços públicos de saneamento básico por entidade que não integre a administração do titular depende da celebração de contrato, sendo vedada sua disciplina mediante convênios, termos de parceria ou outros instrumentos de natureza precária. Dispositivo aplicável tanto no caso da delegação para privados quanto nas hipóteses de prestação por órgãos ou entidades da administração por meio de contrato de programa.

17. As condições de validade dos contratos de concessão e dos contratos de programa no saneamento são estabelecidas pelo $\S 2^{\circ}$ do art. 11 da Lei n. 11.445/07: (i) existência de plano de saneamento básico; (ii) existência de estudo comprovando a viabilidade técnica e econômico-financeira da prestação universal e integral dos serviços, nos termos do respectivo plano de saneamento básico; (iii) existência de normas de regulação que prevejam os meios para o cumprimento das diretrizes na Lei Nacional de Saneamento, incluindo a designação da entidade de regulação e de fiscalização; e (iv) realização prévia de audiência e de consulta públicas sobre o edital de licitação, no caso de concessão, e sobre a minuta do contrato.

18. O conteúdo regulatório mínimo que irá reger os contratos de concessão e de programa é estabelecido pelo $\S 2^{\circ}$ do art. 11 da Lei n. 11.445/07: (i) a autorização para a contratação dos serviços, indicando os respectivos prazos e a área a ser atendida; (ii) a inclusão, no contrato, das metas progressivas e graduais de expansão dos serviços, de qualidade, de eficiência e de uso racional da água, da energia e de outros recursos naturais, em conformidade com os serviços a serem prestados; (iii) as prioridades de ação, compatíveis com as metas estabelecidas; (iv) as condições de sustentabilidade e equilíbrio econômico-financeiro da prestação dos serviços em regime de eficiência, incluindo: a) o sistema de cobrança e a composição de taxas e tarifas; b) a sistemática de reajustes e de revisões de taxas e tarifas; c) a política de subsídios; ( $v$ ) mecanismos de controle social nas 
atividades de planejamento, regulação e fiscalização dos serviços e (vi) as hipóteses de intervenção e de retomada dos serviços.

19. Assim como no caso dos consórcios públicos e convênios de cooperação, os contratos de programa se inserem no quadro referente à nova administração pública consensual. O contrato de programa somente poderá ser formalizado sob o pálio de um consórcio público ou convênio de cooperação.

20. O contrato de programa apresenta grande importância para o modelo da gestão associada, pois figura como condição de validade das "obrigações que um ente da Federação constituir para com outro ente da Federação ou para com consórcio público no âmbito da gestão associada em que haja a prestação de serviços públicos ou a transferência total ou parcial de encargos, serviços, pessoal ou de bens necessários à continuidade dos serviços transferidos" (art.13, caput, da Lei n. 11.107/2005).

21. É nula a cláusula de contrato de programa que atribuir ao contratado o exercício dos poderes de planejamento, regulação e fiscalização dos serviços por ele próprio prestados. A determinação evita a associação de competências de execução com as competências de controle, regulação e fiscalização dos serviços. A regra deverá ser respeitada em toda e qualquer situação, e não apenas no caso da prestação por meio de contrato de programa. Em nenhuma hipótese o prestador dos serviços deve cumular as competências de regulação e fiscalização, tendo em vista os desvios que esta indevida congregação de competências pode acarretar.

22. O contrato de programa assume funções próximas às de um contrato de concessão.

23. O contrato de programa se apresenta como clara tentativa para a regularização e sedimentação das relações entre Municípios e empresas estaduais prestadoras de serviço público de saneamento básico (oriundas, em grande parte, do modelo Planasa). Com a alteração do art. 241 da Constituição e com a edição da Lei n. 11.107/2005 e da Lei n. 11.445/2007, as relações institucionais entre empresas estaduais e Municípios deverão, paulatinamente, ser integradas à gestão associada de serviços públicos.

24. A colocação das empresas estaduais, por meio da gestão associada, no seu verdadeiro e legítimo papel de prestadoras (e não reguladoras) dos serviços pode, efetivamente, auxiliar na continuidade e na ampliação do saneamento. 
25. As regiões metropolitanas apresentam inúmeros desafios institucionais: falta de incentivos dos Estados e Municípios para a divisão de atribuições administrativas em razão do risco de perda de posições políticas relativas; elevados custos de transação decorrentes de integração decisória de diversos entes federados com características políticas e econômicas próprias (morosidade das decisões e ausência de consenso) e dificuldades operacionais, como falta de financiamento para a execução de políticas públicas.

26. Muitos são as posições a respeito dos ditames jurídicos atinentes ao funcionamento das regiões metropolitanas. Diante dos posicionamentos jurisprudenciais e doutrinários analisados quando da discussão da titularidade do saneamento, adotou-se como premissa do trabalho a necessidade de conjugação decisória dos Municípios nos assuntos metropolitanos como condição de legitimidade e juridicidade da gestão dessas áreas, embora se reconheça os inúmeros custos de transação associados a esse modelo.

27. A situação metropolitana não cria nova entidade política, mas uma área de serviços especiais de natureza administrativa. A forma jurídica da unidade decisória das regiões metropolitanas pode assumir feições variadas, sendo muito comum sua estruturação como autarquia ou órgão administrativo de caráter colegiado criados por lei complementar estadual. O relevante é que a participação dos Municípios seja assegurada. Algumas medidas podem ser criadas para contornar ou, ao menos, mitigar os custos de transação presentes nesse contexto: criação de linhas de incentivo e definição de subdivisões administrativas em que apenas os Municípios que compartilhem as funções comuns efetivamente participem das decisões atinentes à sua gestão.

28. A respeito das funções de interesse comum no saneamento, embora seja possível delimitar critérios territoriais ou de responsabilidade sobre seu financiamento para sua identificação, não é possível encontrar indicadores absolutos para sua qualificação, fazendo-se necessário o exame concreto da realidade metropolitana.

29. A aplicação de figuras consensuais de cooperação federativa tem sido vista como uma medida complementar que visa mitigar as dificuldades da gestão metropolitana, uma vez que facilitam debates e tornam mais focada a atuação das entidades políticas; reduzem as dificuldades de transação política, tendo em vista que permitem a valorização de papel daqueles entes encarregados de maiores responsabilidades ou investimentos na consecução dos serviços comuns; e permitem maior flexibilidade à gestão metropolitana, 
possibilitando a transferência de competências a terceiros que, do contrário, deveriam ser realizadas conjuntamente pelas unidades políticas abrangidas pela região metropolitana.

30. A competência para regular, fiscalizar e organizar os serviços qualificados como funções de interesse comum pertence, naturalmente, ao conjunto de entes federativos implicados na gestão metropolitana.

31. O planejamento dos serviços comuns de saneamento nas áreas metropolitanas será, necessariamente, desempenhado em conjunto pelos Municípios.

32. A competência para outorgar concessão, permissão e autorização dos serviços de saneamento considerados como funções comuns será do órgão ou entidade de caráter metropolitano.

33. A prestação dos serviços poderá assumir diversos formatos ou desenhos. Poderá ser delegada a sua prestação a um ou mais particulares, dependendo dos estudos econômicos e financeiros realizados, podendo ser cogitada a prestação direta pela unidade administrativa metropolitana, embora tal medida se apresente um tanto improvável considerando os elevados recursos humanos e materiais a serem alocados na preparação da gestão metropolitana. A transferência da prestação a órgão ou entidade estadual como empresas prestadores de serviços de saneamento apresenta-se, mais uma vez, como opção viável. Para que ocorra sem licitação, exigir-se-á a formalização de convênio de cooperação e de contrato de programa.

34. A aplicação de subsídios cruzados configura-se uma importante justificativa econômica para a instauração da gestão compartilhada. Reconhece-se que os subsídios cruzados podem provocar desvios na eficiência econômica dos serviços. Se utilizados com clareza e de forma a beneficiar grupos individualizáveis de usuários, conformam um importante instrumento de universalização do saneamento. 


\section{REFERÊNCIAS}

ABRUCIO, Luiz Fernando. Para além da descentralização: os desafios da coordenação federativa no Brasil. In: FLEURY, Sonia. Democracia, descentralização e desenvolvimento: Brasil e Espanha. Rio de Janeiro: Editora FGV, 2006.

ALLES, José Joaquín Fernández. Bases para uma teoría constitucional española sobre relaciones intergubernamentales. Revista Española de Derecho Constitucional, Año 24, n. 72, 2004.

ALMEIDA, Fernanda Dias Menezes de. Competências na Constituição de 1988. 2. ed. São Paulo: Atlas, 2000.

ALMEIDA, Marina Hermínia Tavares de. O Estado no Brasil contemporâneo: um passeio pela história. In: MELO, Carlos Ranulfo; SÁEZ, Manuel Alcântara (Org.). A democracia brasileira. Belo Horizonte: Editora UFMG, 2007.

ALTAMIRA GIGENA, Julio Isidro. El servicio público en el derecho administrativo actual. Anales de la Academia Nacional de Derecho y Ciencias Sociales de Córdoba. Córdoba, n. 36, p. 231-237, 1997.

ALVES, Alaôr Caffé. Regiões metropolitanas, aglomerações urbanas e microrregiões: novas dimensões constitucionais da organização do estado brasileiro. Revista de Direito Ambiental, São Paulo, n. 15, p. 184-206, 1999.

ALVES, Alaôr Caffé. Saneamento Básico. Concessões, permissões e convênios públicos. Bauru: Edipro, 1998.

AMARAL, Antônio Carlos Cintra do. Distinção entre usuário de serviço público e Consumidor. Revista Eletrônica de Direito Administrativo Econômico, Salvador, Instituto de Direito Público da Bahia, n. 6, maio/jun./jul. 2006. Disponível em:

$<$ http://www.direitodoestado.com.br>. Acesso em: 16 nov. 2006.

ANASTASIA, Antonio Augusto Junho. Reforma do Estado: uma necessidade? Revista do Tribunal de Contas do Estado de Minas Gerais, Belo Horizonte, v. 25, n. 4, p. 17-31, out./dez. 1997.

ARAGÃO, Alexandre Santos de. A consensualidade no direito administrativo. Revista de Informação Legislativa, Brasília, Ano 42, n. 167, p. 293-310, jul./set. 2005. 
ARAGÃO, Alexandre Santos de. Agências reguladoras. Rio de Janeiro: Forense, 2002.

ARAGÃO, Alexandre Santos de. Direito dos serviços públicos. Rio de Janeiro: Forense, 2007.

ARAGÃO, Alexandre Santos de. Princípio da legalidade e poder regulamentar no Estado contemporâneo. Revista de Direito Administrativo, Rio de Janeiro, n. 225, jul./set. 2001.

ARAGÃO, Alexandre Santos de. Serviços públicos e concorrência. Revista de Direito Administrativo, Rio de Janeiro, n. 233, p. 311-371, jul./set. 2003.

ARAGÃO, Maria Alexandra de Sousa. O direito dos resíduos. Coimbra: Almedina, 2003.

ARAÚJO, Edmir Netto de. Do negócio jurídico administrativo. São Paulo: Editora Revista dos Tribunais, 1992.

ARAÚJO, Florivaldo Dutra de; MAGALHÃES, Gustavo Alexandre. Convênios e consórcios como espécies contratuais e a Lei n. 11.107/2005. In: PIRES, Maria Coeli Simões; BRAZ, Maria Elisa (Coord.). Consórcios públicos: instrumento do federalismo cooperativo. Belo Horizonte: Fórum, 2008, p. 125-144.

ARAÚJO, Marcos Paulo Marques. Serviço de limpeza urbana à luz da lei de saneamento básico. Belo Horizonte: Fórum, 2008.

ARRETCHE, Marta. Estado federativo e políticas sociais: determinantes da descentralização. Rio de Janeiro: Revan; São Paulo: FAPESP, 2000.

ATALIBA, Geraldo. Empresas estatais e regime administrativo (serviço público inexistência de concessão - delegação - proteção ao interesse público). Revista Trimestral de Direito Público, São Paulo, n. 4, p. 55-70, 1993.

ATALIBA, Geraldo; FOLGOSI, Roselea. Saneamento básico - Serviço público estadual e municipal - Contrato administrativo entre Sabesp e município - Concessão não ordinária. Revista Trimestral de Direito Público, São Paulo, n. 9, p. 105-122, 1995.

AUBY, Jean Francois. La delegation de service public: premier bilan et perspectives. Revue du Droit Public et de la Science Politique en France et a l'Etranger, Paris, n. 4, p. 1.095-1.115, juil./sept. 1996. 
AZEVEDO, Sérgio de. Os dilemas institucionais da gestão metropolitana no Brasil. In: RIBEIRO, Luiz Cesar de Queiroz (Org.). Metrópoles: entre a coesão e a fragmentação, a cooperação e o conflito. São Paulo: Editora Fundação Perseu Abramo; Rio de Janeiro: FASE - Federação de Órgãos para Assistência Social e Educacional, 2004.

AZEVEDO, Sérgio de; MARES GUIA, Virgínia Rennó dos. A gestão do transporte na Região Metropolitana de Belo Horizonte. Revista de Administração Pública, Rio de Janeiro, 2000.

BACELAR FILHO, Romeu Felipe. O poder normativo dos entes reguladores e a participação dos cidadãos nesta atividade. Serviços públicos e direitos fundamentais: os desafios da regulação na experiência brasileira. Revista de Direito Administrativo, Rio de Janeiro, n. 230, p. 153-162, out./dez. 2002.

BACHOF, Otto; STOBER, Rolf; WOLFF, Hans J. Direito administrativo. Lisboa: Calouste Gulbenkian. 2006, v. 1.

BAPTISTA, Jaime Melo; PÁSSARO, Dulce Álvaro; SANTOS, Rui Ferreira dos. O modelo de regulação das águas e resíduos em Portugal. Revista de Direito Público da Economia, Belo Horizonte, n. 3, p. 103-115, jul./set. 2003.

BARACHO, Jose Alfredo de Oliveira. O principio de subsidiariedade: conceito e evolução. Rio de Janeiro: Forense, 1996.

BARACHO, Jose Alfredo de Oliveira. Teoria geral do federalismo. Belo Horizonte: FUMARC/UCMG, 1982.

BARBOSA, Andréa Campos; FREITAS, Maria Ângela Albuquerque de. Normatização tarifária: uma contribuição para as discussões no âmbito das agências reguladoras. In: GALVÃO JUNIOR, Alceu de Castro. XIMENES, Marfisa Maria de Aguiar Ferreira (Org.). Regulação: normatização da prestação de serviços de água e esgoto. Fortaleza: ABAR, 2008.

BARROSO, Luis Roberto. Interpretação e aplicação da Constituição. 6. ed. São Paulo: Saraiva, 2004.

BARROSO, Luis Roberto. Saneamento básico: competências constitucionais da União, Estados e Municípios. Revista Diálogo Jurídico, Salvador, Centro de Atualização Jurídica (CAJ), n. 13, abril-maio, 2002. Disponível em: <http://www.direitopublico.com.br>. Acesso em: 15 nov. 2006. 
BAUDIN-CULLIÈRE, Fréderic. Principe de subsidiarité et administration locale. Paris: LGDJ, 1995.

BERCOVICI, Gilberto. Desigualdades regionais, estado e Constituição. São Paulo: Max Limonad, 2003.

BERCOVICI, Gilberto; SIQUEIRA NETO, José Francisco. O artigo 23 da Constituição de 1988 e as competências comuns. Revista Brasileira de Estudos Constitucionais, Belo Horizonte, ano 2, n. 6, p. 49-65, abr./jun., 2008.

BIELSCHOWSKY, Ricardo. Pensamento economico brasileiro: o cliclo ideológico do desenvolvimentismo. Rio de Janeiro: Contraponto, 2000.

BLONDEAU, Ange. La concession de service public. 2. ed. Paris: Dalloz, 1933.

BOBBIO, Norberto. Estado, governo, sociedade, para uma teoria geral da política. 3. ed. São Paulo; Rio de Janeiro: Paz e Terra, 1990.

BONAVIDES, Paulo. A Constituição aberta: temas políticos e constitucionais da atualidade, com ênfase no federalismo das regiões. São Paulo: Malheiros, 2004.

BONAVIDES, Paulo. Curso de direito constitucional. 12. ed. São Paulo: Malheiros, 2002.

BORGES, Alice Gonzalez. Concessões de serviço público de abastecimento de água aos municípios. Revista Trimestral de Direito Público, São Paulo, n. 17, p. 39-48, 1997.

BORGES, Alice Gonzalez. Os consórcios públicos na sua legislação reguladora. Jus Navigandi, Teresina, a. 9, n. 755, 29 jul. 2005. Disponível em:

<http://jus2.uol.com.br/doutrina/texto.asp?id=7072>. Acesso em: 15 fev. 2006.

BRITO MACHADO, Hugo de. A área do imóvel como elemento de determinação da taxa de coleta domiciliar de lixo, São Paulo, n. 1, p. 35-41, 2005.

BUCCI, Maria Paula Dallari. Direito administrativo e políticas públicas. São Paulo: Saraiva, 2002.

BURGESS, Michael. Federalism and federation: a reappraisal. In: BURGESS, Michael; GAGNON, Alain (Ed.) Comparative federalism and federation. London: Harvester, Wheastsheaf, 1993., apud ABRUCIO, Luiz Fernando. Para além da descentralização: os 
desafios da coordenação federativa no Brasil. In: FLEURY, Sonia. Democracia, descentralização e desenvolvimento: Brasil e Espanha. Rio de Janeiro: Editora FGV, 2006.

CÂMARA, Jacintho Arruda. O regime tarifário como instrumento de políticas públicas. Revista de Direito Público da Economia, Belo Horizonte, n. 12, p. 95-127, out./dez. 2005.

CÂMARA, Jacintho Arruda. O regime tarifário nas concessões de serviços públicos. 2004. 300 f. Tese (Doutorado em Direito do Estado) - Pontifícia Universidade Católica, São Paulo, 2004.

CAMPILONGO, Celso Fernandes. Serviço público e regulação sistêmica. In: TÔRRES, Heleno Taveira (Org.). Serviços públicos e direito tributário. São Paulo: Quartier Latin, 2005 .

CARLI, Paolo di. Lezioni ed argomenti di Diritto Pubblico dell' economia. Padova: CEDAM, 1995.

CARVALHO, Paulo Neves. Gestão associada de serviços públicos: consórcios intermunicipais. Revista Brasileira de Direito Municipal, Belo Horizonte, n. 7, p. 51-62, jan./mar. 2003.

CASSAGNE, Juan Carlos. La huelga en los servicios esenciales. Madrid: Civitas, 1993.

CAVALCANTI, José Carlos Silva. A reforma do sistema financeiro de saneamento elementos para uma discussão. São Paulo, 1985. Mimeo. apud JORGE, Wilson Edson. A política nacional de saneamento pós-64. 259 f. Tese (Doutorado em Arquitetura e Urbanismo) - Faculdade de Arquitetura e Urbanismo, Universidade de São Paulo, São Paulo, 1987.

CHEVALLIER, Jacques. A reforma do Estado e a concepção francesa de serviço público. Revista de Serviço Público, v. 120, n. 3, p. 35-58, set./dez. 1996.

CHEVALLIER, Jacques. Le service public. Paris: PUF, 1991.

CLARICH, Marcelo. Servizio pubblico e sevizio universale: evoluzione normativa e profili ricostruttivi. Diritto Pubblico, Padova, CEDAM, n. 1, p. 181-200, 1998.

CORRÊA, Antônio Celso Di Munno. Planejamento urbano: competência para legislar dos Estados e dos Municípios. Revista dos Tribunais, São Paulo, n. 646, p. 41-48, 1989. 
COSER, Ivo. Visconde do Uruguai: centralização e federalismo no Brasil - 1823-1866. Belo Horizonte: Editora UFMG, 2008.

COUTINHO, Diogo Rosenthal. A universalização do serviço público para o desenvolvimento como uma tarefa para a regulação. In: SALOMÃO FILHO, Calixto (Coord.). Regulação e desenvolvimento. São Paulo: Malheiros, 2002.

COUTINHO, Diogo Rosenthal. Regulação e redistribuição: a experiência brasileira de universalização das telecomunicações. 2003. 323f. Tese (Doutorado em Filosofia e Teoria Geral do Direito) - Faculdade de Direito, Universidade de São Paulo, São Paulo, 2003.

CUÉLLAR, Leila. A reforma do Estado e a concepção francesa de serviço público. Revista de Serviço Público, v. 120, n. 3, p. 35-58, set./dez. 1996.

CUÉLLAR, Leila. Serviço de abastecimento de água e a suspensão do fornecimento. Revista de Direito Público da Economia, Belo Horizonte, n. 3, p. 131-159, jul./set. 2003.

DALLARI, Adilson de Abreu. Administração pública no Estado de Direito. Revista Trimestral de Direito Público, São Paulo, n. 5, p. 33-41.

DALLARI, Adilson de Abreu. O uso do solo metropolitano. Revista de Direito Público, São Paulo, n. 14, p. 285-291, 1970.

DALLARI, Adilson de Abreu. Tarifa remuneratória de serviços concedidos. In: TÔRRES, Heleno Taveira (Org.). Serviços públicos e direito tributário. São Paulo: Quartier Latin, 2005 .

DALLARI, Dalmo de Abreu. Parecer jurídico a respeito do Projeto de Lei n. 5.296/2005 que estabelece as diretrizes para os serviços públicos de saneamento básico e Política Nacional de Saneamento Básico (PNS). 2005. Parecer formulado a pedido do Ministério das Cidades.Disponível em:

<http://www.cidades.gov.br/media/PlanoTrabalho/Dalmo.pdf>. Acesso em: 12 nov. 2006.

DELVOLVÉ, Pierre. Droit administratif. Tome 2. Paris: PUF. 1992.

DI PIETRO, Maria Sylvia Zanella (Org.). Direito regulatório: temas polêmicos. Belo Horizonte: Fórum, 2004.

DI PIETRO, Maria Sylvia Zanella. 500 anos de direito administrativo brasileiro. Revista da Procuradoria Geral do Estado da Bahia, Salvador, v. 26, p. 29-54, jan./dez. 2000. 
DI PIETRO, Maria Sylvia Zanella. Compartilhamento de infra-estrutura por concessionárias de serviços públicos. Fórum Administrativo, Belo Horizonte, v. 2, n. 11, p. 43-52, jan. 2002.

DI PIETRO, Maria Sylvia Zanella. Concessões e permissões sob a tutela da Lei n. 8.987, de 13.2.95. Boletim de Direito Administrativo, São Paulo, v. 12, n. 2, p. 57-61, fev. 1996.

DI PIETRO, Maria Sylvia Zanella. Direito administrativo. 21. ed. São Paulo: Atlas, 2008a.

DI PIETRO, Maria Sylvia Zanella. O Consórcio Público na Lei n. ${ }^{\text {o } 11.107, ~ d e ~ 6.4 .2005 . ~}$ Revista Eletrônica de Direito de Estado, Salvador, Instituto de Direito Público da Bahia, n. 3, jul./ago./set. 2005b. Disponível em: <http://www.direitodoestado.com.br> Acesso em: 15 fev. 2006.

DI PIETRO, Maria Sylvia Zanella. O sistema de parceria entre os setores público e privado: execução de serviços através de concessão, permissão e terceirização. Boletim de Direito Administrativo, São Paulo, v. 13, n. 9, p. 586-590, set. 1997.

DI PIETRO, Maria Sylvia Zanella. Parcerias na administração pública. 3. ed. São Paulo: Atlas, 2008b.

DI PIETRO, Maria Sylvia Zanella. Regulação, poder estatal e controle social. Revista de Direito Público da Economia, Belo Horizonte, n. 11, p. 163-172, jul./set. 2005a.

DI PIETRO, Maria Sylvia Zanella. Serviços públicos concedidos. Boletim de Direito Administrativo, São Paulo, v. 21, n. 1, p. 11-19, jan. 2005.

DI PIETRO, Maria Sylvia Zanella. Sistema de concessão de exploração de rodovia. Fórum de contratação e gestão pública, Belo Horizonte, v. 1, n. 11, p. 1.339-1.349, nov. 2002.

DI PIETRO, Maria Sylvia Zanella. Terceirização dos serviços públicos. Boletim de Direito Administrativo, São Paulo, v. 12, n. 1, p. 16-19, jan. 1996.

DIAS, Maria Tereza Fonseca. Consórcios públicos e organização administrativa, em face da Constituição da Republico de 1988. In: PIRES, Maria Coeli Simões; BRAZ, Maria Elisa (Coord.). Consórcios públicos: instrumento do federalismo cooperativo. Belo Horizonte: Fórum, 2008, p. 87-113.

DUTRA, Pedro. O Poder regulamentar dos órgãos reguladores. Revista de Direito Administrativo, Rio de Janeiro, n. 221, p. 239-256, jul./set. 2000. 
ENTRENA CUESTA, Rafael. Curso de derecho administrativo. 13. ed. Madrid: Tecnos, 1999, 2v.

ESTORNINHO, Maria João. A fuga para o direito privado: contributo para o estudo da actividade de direito privado da administração publica. Coimbra: Almedina, 1996.

ESTORNINHO, Maria João. Requiem pelo contrato administrativo. Coimbra: Almedina, 1990.

FARIA, José Eduardo. Direito e economia na democratização brasileira. São Paulo: Malheiros, 1993.

FERRAZ JÚNIOR, Tércio Sampaio. Normas gerais e competência concorrente: uma exegese do artigo 24 da Constituição Federal. Revista Trimestral de Direito Público, n. 7 , 1994.

FERRAZ, Sérgio. As regiões metropolitanas no direito brasileiro. Revista de Direito Público, São Paulo, n. 37, p. 19-24, jan./jun. 1976.

FERREIRA, Fernanda Meirelles. Regulação por contrato no setor do saneamento. 2005. 129f. Dissertação (Mestrado em Administração Pública e Governo) - Escola de Administração de Empresas de São Paulo, Fundação Getúlio Vargas, São Paulo, 2005.

FIGUEIREDO, Guilherme José Purvin de. Resíduos sólidos: ponto final da insustentabilidade econômica. Revista de Direitos Difusos, Porto Alegre, v. 13, p.17171731, jun. 2002.

FOLGOSI, Roselea. Saneamento básico - Serviço público estadual e municipal - Contrato administrativo entre Sabesp e município - Concessão não ordinária. Revista Trimestral de Direito Público, São Paulo, n. 9, p. 105-122, 1995.

FORTINI, Cristiana; ROCHA, Rúsvel Beltrame. Consórcios públicos, contratos de programa e a Lei de Saneamento. In: PICININ, Juliana; FORTINI, Cristiana. Saneamento básico: estudos e pareceres à luz da lei n. 11.445/2007. Belo Horizonte: Editora Fórum, 2009.

FREITAS, Juarez. A democracia como princípio jurídico. In: FERRAZ, Luciano; MOTTA, Fabrício. Direito público moderno. 1. ed. Belo Horizonte: Del Rey, 2003. 
FREITAS, Juarez. A interpretação sistemática do direito. 4. ed. São Paulo: Malheiros Editores, 2004b.

FREITAS, Juarez. O controle dos atos administrativos e os princípios fundamentais. 3. ed. São Paulo: Malheiros, 2004a.

FREITAS, Juarez. O controle social e o consumidor de serviços públicos. Revista Trimestral de Direito Público, São Paulo, n. 23, p. 24-31, 1998.

FREITAS, Juarez. O Estado essencial e o regime de concessões e permissões de serviços públicos. In: FREITAS, Juarez. Estudos de Direito Administrativo. 2. ed. São Paulo: Malheiros, 1997.

GARCÍA DE ENTERRÍA, Eduardo. <<Prólogo >> a A. Huergo Lora: Los contratos sobre los actos y las potestades administrativas, Civitas-Universidad de Oviedo, Madrid, 1998, p. 13, apud REIGADA, Antonio Troncoso. Dogmática administrativa y derecho constitucional: el caso del servicio publico. Revista Española de Derecho Constitucional, Madrid, n. 57, p. 87-164, 1999.

GARCIA DE ENTERRIA, Eduardo; FERNÁNDEZ, Tomás-Ramón. Curso de direito administrativo. Trad. Arnaldo Setti, São Paulo: Editora Revista dos Tribunais, 1991.

GARCIA, Maria da Glória Pinto. Reinventing public service between the autonomy of the market and the duty of public interest. Direito e Justiça: Revista da Faculdade de Direito da Universidade Católica Portuguesa, Lisboa, v. 15, n. 2, p. 71-84, 2001.

GAUDAMET, Yves ; LAUBADÈRE, André de; VENEZIA, Jean-Claude. Traité de droit administratif. 13. ed. Paris: L.G.D.J, 1999, t. I.

GAUDIN, Jean Pierre. Gouverner par contrat: 1'action publique en question. Paris: Presses de Sciences Politiques, 1999 apud MEDAUAR, Odete; OLIVEIRA, Gustavo Justino de. Consórcios públicos. São Paulo: Editora Revista dos Tribunais, 2006.

GIANNINI, Massimo Severo. Diritto pubblico dell' economia. Bologna: Il Mulino, 1985.

GOMEZ ARBOLEYA, Enrique. Estudios de teoría de la sociedad y del estado. Madrid: Instituto de Estudios Politicos, 1962.

GONÇALVES, Pedro. A concessão de serviços públicos. Coimbra: Almedina, 1999. 
GORDILlO, Augustín. Tratado de derecho administrativo. Belo Horizonte: Del Rey, 2003, 3 tomos.

GOUVÊA, Ronaldo Guimarães. A questão metropolitana no Brasil. Rio de Janeiro: Editora FGV, 2005.

GRANZIERA, Maria Luiza Machado. Concessão de serviços públicos de limpeza pública, coleta domiciliar, tratamento e destinação final do lixo: aspectos jurídicos. Boletim de Direito Municipal, São Paulo, n. 7, p. 421-430, 1998.

GRAU, Eros Roberto. A ordem econômica na Constituição de 1988: interpretação e critica. 10. ed. São Paulo: Malheiros, 2008.

GRAU, Eros Roberto. Direito urbano: regiões metropolitanas, solo criado, zoneamento e controle ambiental, projeto de lei de desenvolvimento urbano. São Paulo: Editora Revista dos Tribunais, 1983.

GRAU, Eros Roberto. Princípio da livre concorrência: função normativa e função regulamentar. Revista Trimestral de Direito Público, São Paulo, n. 4, p. 104-129, 1993.

GRAU, Eros Roberto. Regiões metropolitanas: regime jurídico. São Paulo: 1974.

GROTTI, Dinorá Adelaide Musetti. O serviço público e a Constituição de 1988. São Paulo: Malheiros, 2003.

GUSTIN, Miracy Barbosa de Sousa; DIAS, Maria Tereza Fonseca. (Re)pensando a pesquisa jurídica: teoria e prática. Belo Horizonte: Del Rey, 2006.

HABERMAS, Jürgen. O discurso filosófico da Modernidade. São Paulo: Martins Fontes, 2002.

HAMILTON, Alexander. O federalista. Rio de Janeiro: Editora Nacional de Direito, 1959.

HELLER, Léo. Abastecimento de água para consumo humano. Belo Horizonte: UFMG, 2006.

HELLER, Léo; REZENDE, Sonaly Cristina. O saneamento no Brasil: políticas e interfaces. Belo Horizonte: Editora UFMG, 2008. 
HENRY, Claude. Concurrence et services publique dans l'Union Européenne. Paris: PUF, 1997.

HESPANHA, António Manuel. O caleidoscópio do direito: o direito e a justiça nos dias e no mundo de hoje. Coimbra: Almedina, 2007.

HESSE, Konrad. A força normativa da Constituição. Porto Alegre: Fabris, 1991.

HESSE, Konrad. Elementos de direito constitucional da República Federal da Alemanha. Porto Alegre: Fabris, 1998.

HORTA, Raul Machado. As novas tendências do federalismo e seus reflexos na Constituição de 1988. Revista do Legislativo, Belo Horizonte, n. 25, jan./mar. 1999.

HORTA, Raul Machado. O federalismo e o princípio da subsidiariedade. In: MARTINS, Ives Gandra da Silva (Org.). As vertentes do direito constitucional contemporâneo. Rio de Janeiro: América Jurídica, 2002.

IRTI, Natalino (Org.). Diritto ed economia. Padova: Cedam, 1999.

IRTI, Natalino. A ordem jurídica do mercado. Texto apresentado em seminário realizado na Faculdade de Direito de São Paulo em 2008.

JEZE, Gaston. Les principes généraux du droit administratif. 3. ed. rev. et aug. Paris: Marcel Giard, 1934.

JORGE, Wilson Edson. A política nacional de saneamento pós-64. 259f. Tese (Doutorado em: Arquitetura e Urbanismo) - Faculdade de Arquitetura e Urbanismo, Universidade de São Paulo, São Paulo, 1987.

JOURDAN, Philippe. La formation du concept de service public. Revue du Droit Public et de la Science Politique en France et a l'Etranger, Paris, n. 1, p. 89-118, jan./fev. 1987.

JUSTEN FILHO, Marçal. As diversas configurações das concessões de serviço público. Revista de Direito Público da Economia. Belo Horizonte, n. 1, p. 95-136, jan./mar. 2003a.

JUSTEN FILHO, Marçal. O direito das agências reguladoras independentes. São Paulo: Dialética, 2002. 
JUSTEN FILHO, Marçal. Parecer Elaborado sobre a Proposta Legislativa de criação de Consórcios Públicos. Revista Eletrônica de Direito do Estado, Salvador, Instituto de Direito Público da Bahia, n. 3, jul./ago./set. 2005b. Disponível em:

$<$ http:www.direitodoestado.com.br>. Acesso em: 15 fev. 2006.

JUSTEN FILHO, Marçal. Parecer jurídico a respeito do Projeto de Lei n. 5.296/2005 que estabelece as diretrizes para os serviços públicos de saneamento básico e Política Nacional de Saneamento Básico (PNS). 2005a. Disponível em:

<http://www.cidades.gov.br/media/PlanoTrabalho/Marcal.pdf>. Acesso em: 12 nov. 2006. Parecer formulado a pedido do Ministério das Cidades.

JUSTEN FILHO, Marçal. Serviço público no direito brasileiro. Revista de Direito Público da Economia, Belo Horizonte, v. 7, p. 143-169, jul./set. 2004.

JUSTEN FILHO, Marçal. Teoria geral das concessões de serviço público. São Paulo: Dialética, 2003.

JUSTEN, Monica Spezia. O serviço público na perspectiva do direito comunitário europeu. Revista de Direito Público da Economia, Belo Horizonte, n. 1, p. 137-176, jan./mar. 2003.

KRELL, Andreas J. Leis de normas gerais, regulamentação do poder executivo e cooperação intergovernamental em tempos de reforma federativa. Belo Horizonte: Editora Fórum, 2008.

KRELL, Andreas Joachim. Perspectivas dos municípios. In: LIVRO de teses da XVI Conferência Nacional de Advogados. Brasília: OAB, [s.d.].

LAUBADERE, Andre de. Droit public économique. 2. ed. Paris: Dalloz, 1976.

LAUBADERE, Andre de. Traite elementaire de droit administratif. 2. ed. Paris: 1971.

LEVI, Lucio. Federalismo. In: BOBBIO, Norberto; MATTEUCCI, Nicola; PASQUINO, Gianfranco (Org.). Dicionário de política. 11. ed. Brasília: UnB, 1998, v. 1.

LOPES, Alberto. Gestão Metropolitana no Brasil: Da coerção simétrica ao voluntarismo sem modelo, em busca da responsabilidade política com resultados. In: FREIRE, Dêsirrêe Guichard; OLIVEIRA, Floriano José Godinho de; SILVA, Catia Antonia da (Org.). Metrópole: governo, sociedade e território. Rio de Janeiro: DP\&A Editora, 2006. 
MACHADO, Paulo Affonso Leme. Direito ambiental brasileiro. 13. ed. São Paulo: Malheiros, 2005.

MACHADO, Paulo Affonso Leme. Recursos hídricos: direito brasileiro e internacional. São Paulo: Malheiros, 2002.

MAGALHÃES, José Luiz Quadros de. Poder municipal. 2. ed. Belo Horizonte: Del Rey, 1999.

MANKIW, N. Gregory. Princípios de microeconomia. São Paulo: Pioneira, Thomson Learning, 2005.

MARENCO, André. Devagar se vai ao longe? In: MELO, Carlos Ranulfo; SÁEZ, Manuel Alcântara. (Org.). A democracia brasileira. A democracia brasileira. Belo Horizonte: Editora UFMG, 2007.

MARQUES NETO, Floriano de Azevedo. A nova regulação dos serviços públicos. Revista de Direito Administrativo, Rio de Janeiro, Renovar, FGV, n. 228, p. 13-29, abr./jun. 2002a.

MARQUES NETO, Floriano de Azevedo. As parcerias público-privadas no saneamento ambiental. Revista Eletrônica de Direito Administrativo Econômico, Salvador, n. 2, maio/jun./jul. 2005a. Disponível na Internet:<http://www.direitodoestado.com.br $>$. Acesso em: 17 nov. 2006.

MARQUES NETO, Floriano de Azevedo. Aspectos regulatórios em um novo modelo para o setor de saneamento básico no Brasil. Revista de Direito Administrativo, Rio de Janeiro, n. 224, p. 79-94, abr./jun. 2001.

MARQUES NETO, Floriano de Azevedo. Concessão de serviço público sem ônus para o usuário. In: . Direito público: estudos em homenagem ao Professor Adilson Abreu Dallari. Belo Horizonte: Del Rey, 2004.

MARQUES NETO, Floriano de Azevedo. Direito das telecomunicações e Anatel. In: SUNDFELD, Carlos Ari (Org.). Direito administrativo econômico. São Paulo: Malheiros, 2002b.

MARQUES NETO, Floriano de Azevedo. Limites à abrangência e à intensidade da Regulação Estatal. Revista Eletrônica de Direito Administrativo Econômico, Salvador, Instituto de Direito Público da Bahia, n. 4, nov./dez. 2005b, jan. 2006. Disponível em:<http://www.direitodoestado.com.br>. Acesso em: 12 nov. 2006. 
MARQUES NETO, Floriano de Azevedo. Parecer jurídico a respeito do Projeto de Lei $n$. 5.296/2005 que estabelece as diretrizes para os serviços públicos de saneamento básico e Política Nacional de Saneamento Básico (PNS). 2005c. Disponível em: $<$ http://www.cidades.gov.br/media/PlanoTrabalho/Floriano.pdf>. Acesso em: 12 nov. 2006. Parecer formulado a pedido do Ministério das Cidades.

MARQUES NETO, Floriano de Azevedo. Regulação estatal e interesses públicos. São Paulo: Malheiros, 2002c.

MARQUES NETO, Floriano de Azevedo; QUEIROZ, João Eduardo Lopes. Planejamento. In: MARTINS CARDOZO, José Eduardo; LOPES QUEIROZ, João Eduardo; BATISTA DOS SANTOS, Márcia W. (Org.). Curso de direito administrativo econômico. São Paulo: Malheiros, 2006, v. II.

MARTÍN, Encarnación Montoya. Las empresas públicas sometidas al derecho privado. Madrid: Marcial Pons, 1996.

MARTINAND, Claude. Le service public en France et en Europe. Revue des Affaires Europeennes, Paris, n. 2, p. 80-91, 1994.

MARTINS, Adriana Vassallo. Notas sobre as articulações entre o estado brasileiro e suas empresas estatais: o caso do contrato de gestão da Companhia Vale do Rio Doce. Disponível em: $<$ http://www.planejamento.gov.br/arquivos_down/dest/palestra_Adriana_Vassallo.pdf $>$. Acesso em: 15 jun. 2007.

MARTINS, Paulo Alexandre de Gouveia. Manejo de águas pluviais urbanas: estudos de bacias de amortecimento na região metropolitana de São Paulo. Dissertação (PósGraduação em Arquitetura e Urbanismo) - Pontifícia Universidade Católica de Campinas, 2006.

MATTOS, Mauro Roberto Gomes de. Agências reguladoras e as suas características. Revista de Direito Administrativo, Rio de Janeiro, n. 218, p. 71-91, out./dez. 1999.

MAURER, Hartmut. Direito administrativo geral. Barueri: Manole. 2006.

MEDAUAR, Odete. Concessão de serviço publico. São Paulo: Editora Revista dos Tribunais, 1995. 
MEDAUAR, Odete. Nova crise do serviço público? In: GRAU, Eros Roberto; CUNHA, Sérgio Sérvulo da (Org.). Estudos de direito constitucional em homenagem a José Afonso da Silva. São Paulo: Malheiros, 2003.

MEDAUAR, Odete. O direito administrativo em evolução. 2. ed. São Paulo: Editora Revista dos Tribunais, 2003.

MEDAUAR, Odete. Regulação e auto-regulação. Revista de Direito Administrativo, Rio de Janeiro, n. 228, p. 123-128, abr./jun. 2002.

MEDAUAR, Odete; OLIVEIRA, Gustavo Justino de. Consórcios públicos: comentários à lei n. 11.107/2005. são Paulo: Editora Revista dos Tribunais, 2006.

MEDAUAR, Odete; OLIVEIRA, Gustavo Justino de. Consórcios públicos. São Paulo: Editora Revista dos Tribunais, 2006.

MEIRELLES, Hely Lopes. Direito administrativo. 15. ed. São Paulo: Malheiros, 1990.

MEIRELLES, Hely Lopes. Direito municipal brasileiro. São Paulo: Malheiros, 2008.

MELLERAY, Fabrice. École de Bordeaux, école du service public et école duguiste: proposition de distinction. Revue du Droit Public et de la Science Politique en France et à L'Étranger, Paris, n. 6, p. 1.887-1.905, nov./dec. 2001.

MELLO, Celso Antônio Bandeira de. Curso de direito administrativo. 18. ed. São Paulo: Malheiros, 2005.

MELLO, Celso Antônio Bandeira de. Serviço público e poder de polícia: concessão e delegação. Revista Trimestral de Direito Público, n. 20, p. 21-28, 1997.

MENARD, Claude. SAUSSIER, Stephane. Contractual choice and performance. In: BROUSSEAU; GLACHANT, Eric Jean-Michel (Ed.). The economics of contracts: theory and applications. Cambridge (UK): Cambridge University Press. 2002. p. 440-462. Disponível em:< http://www.castalia.fr/SITE_Default/x-files/1859.pdf>. Acesso em: 25 maio 2007.

MERKL, Adolfo. Teoria general del derecho administrativo. México: Nacional, 1975. 
MODERNE, Franck. Les experiénces régionalistes em Espagne et au Portugal: analyse comparative. In: MARTINS, Ives Gandra da Silva (Org.). As vertentes do direito constitucional contemporâneo. Rio de Janeiro: América Jurídica, 2002.

MODESTO, Paulo. Reforma do Estado, formas de prestação de serviços públicos e parcerias público-privadas: demarcando as fronteiras dos conceitos de serviço público, serviços de relevância pública e serviços de exploração econômica para as parcerias público-privadas. Revista Eletrônica de Direito Administrativo Econômico, Salvador, , n. 2, maio/jun./jul. 2005. Disponível em: <http://www.direitodoestado.com.br>. Acesso em: 12 nov. 2006.

MONTEIRO, Mário Augusto Parente. Política de subsídios no setor do saneamento básico: rompendo o paradigma dos subsídios cruzados. In: GALVÃO JUNIOR, Alceu de Castro. XIMENES, Marfisa Maria de Aguiar Ferreira (Org.). Regulação: normatização da prestação de serviços de água e esgoto. Fortaleza: ABAR, 2008.

MONTEIRO, Vera. Prestação do serviço de saneamento por meio da gestão associada entre entes federativos. In: PICININ, Juliana; FORTINI, Cristiana. Saneamento básico: estudos e pareceres à luz da lei n. 11.445/2007. Belo Horizonte: Editora Fórum, 2009.

MONTENEGRO, Marcos Helano; TUCCI, Carlos E. M. Saneamento ambiental e águas pluviais. In: LOBO, Rosana (Org.). Gestão do território e manejo integrado das águas urbanas. Brasília: Ministério das Cidades, 2005.

MONTERO PASCUAL, Juan José. La desregulación estadounidense y la última crisis del servicio público en Europa. Boletin Mexicano de Derecho Comparado, México, v. 37, n. 94, p.103-119, ene./abr. 1999.

MORAES, Germana de Oliveira. A influência da evolução sobre serviço público e policia administrativa. Revista da Faculdade de Direito. Universidade Federal do Ceará, Fortaleza, v. 29, n. 2, p. 91-104, jul./dez. 1988.

MOREIRA NETO, Diogo de Figueiredo. Coordenação gerencial na administração pública. Revista de Direito Administrativo, Rio de Janeiro, n. 214, p. 35-53, out./dez. 1998.

MOREIRA NETO, Diogo de Figueiredo. Direito regulatório. Rio de Janeiro: Renovar, 2003.

MOREIRA NETO, Diogo de Figueiredo. Mutações do direito administrativo. 2. ed. Rio de Janeiro: Renovar, 2001. 
MOREIRA, Vital. Os serviços públicos tradicionais sob o impacto da União Européia. Revista de Direito Público da Economia, Belo Horizonte, n. 1, p. 227-248, jan./mar. 2003.

MOTTA, Ronaldo Seroa da. As opções de marco regulatório de saneamento no Brasil. In: ; SALGADO, Lucia Helena (Org.). Regulação e concorrência no Brasil:

governança, incentivos e eficiência. Rio de Janeiro: IPEA, 2007.

MUKAI, Toshio. Concessões dos serviços de saneamento e de água e esgoto: aspectos jurídico-constitucionais. Boletim de Direito Administrativo, São Paulo, n. 2, p. 91-96, 1998.

MUÑOZ MACHADO, Santiago. Servicio público y mercado. Madrid: Civitas, 1998.

NEVES, Castanheira A. O actual problema metodológico da interpretação jurídica. Coimbra: Coimbra, 2003, v. I.

NEWBERY, David M. G. Privatization, restructuring and regulation of network utilities. 3. ed. Cambridge, Massachusetts, London: The MIT Press/The Wahas-Pareto Lectures, 2001.

ORSINI, Luiz Fernando; TUCCI, Carlos E. M. Águas urbanas no Brasil: Cenário atual e desenvolvimento sustentável. In: LOBO, Rosana (org.). Gestão do território e manejo integrado das águas urbanas. Brasília: Ministério das Cidades, 2005.

ORTIZ, Gaspar Ariño. Economia y estado: crisis e reforma del sector público. Madrid: Marcial Pons, 1993 apud GROTTI, Dinorá Adelaide Musetti. 2003.

ORTIZ, Gaspar Ariño. Principios de derecho público econômico. Granada: Comares, 2004.

ORTIZ, Gaspar Ariño. Sucessos e fracassos da regulação. Revista Eletrônica de Direito Administrativo Econômico, Salvador, Instituto de Direito Público da Bahia, n.3, ago./set./out. 2005. Disponível em: <http://www.direitodoestado.com.br>. Acesso em: 8 nov. 2006.

PEIXOTO, João Batista. Sustentabilidade econômica e remuneração da prestação dos serviços de abastecimento de água e de esgotamento sanitário: regulação econômica e fontes de financiamento. In: CORDEIRO, Berenice de Souza (Coord.). Lei nacional de saneamento: perspectivas para as políticas e gestão de serviços públicos Brasília: Editora, 2009. Livro III: Prestação dos serviços públicos de saneamento básico. 
PEREIRA, Cesar A. A participação privada nos serviços de limpeza urbana. Revista de Direito Administrativo, Rio de Janeiro, n. 216, p. 75-108, 1999.

PEREIRA, Cesar A. Guimarães. Concessão de serviços de limpeza urbana: pontos polêmicos. Revista Trimestral de Direito Público, São Paulo, n. 26, p. 217-232, 1999.

PEREZ, Marcos Augusto. O risco no contrato de concessão de serviço público. Belo Horizonte: Fórum, 2006.

PERIN, Roberto Cavallo. La estrutura della concessione di servizio pubblico locale. Torino: Giappichelli, 1998.

PINTO, Bilac. Regulamentação efetiva dos serviços de utilidade pública. 2. ed. Rio de Janeiro: Forense, 2002.

PIRES, Maria Coeli Simões. A institucionalização das regiões metropolitanas e o novo modelo de federalismo brasileiro. Revista de Direito Público, São Paulo, n. 84, 187-194, 1987.

PIRES, Maria Coeli Simões. A institucionalização das regiões metropolitanas e o novo modelo de federalismo brasileiro. Revista de Direito Público, São Paulo, p. 187-194, n. 84, 1987.

PIRES, Maria Coeli Simões. Descentralização e subsidiariedade. Revista do Tribunal de Contas do Estado de Minas Gerais, Belo Horizonte, n. 3, 2000. Disponível em: $<$ http://200.198.41.151:8081/tribunal_contas/2000/03/-sumario?next=2.> Acesso em: 9 ago. 2006.

PISIER-KOUCHNER, Evelyne. Le service public dans la theorie de l'etat de Leon Duguit. Paris: LGDJ, 1972.

PORTO NETO, Benedicto. Parecer jurídico a respeito do Projeto de Lei n. 5.296/2005 que estabelece as diretrizes para os serviços públicos de saneamento básico e política nacional de saneamento básico (PNS). 2005. Disponível em:

$<$ http://www.cidades.gov.br/media/PlanoTrabalho/Benedicto.pdf>. Acesso em: 12 nov. 2006. Parecer formulado a pedido do Ministério das Cidades.

PRADO, Lucas Navarro; RIBEIRO, Maurício Portugal. Comentários à Lei de PPP. São Paulo: Malheiros, 2007. 
RAYMUNDIE, Olivier. Gestion déléguée des services publics em France et en Europe. Paris: Le Moniteur, 1995.

REIGADA, Antonio Troncoso. Dogmática administrativa y derecho constitucional: el caso del servicio publico. Revista Española de Derecho Constitucional, Madrid, n. 57, p. 87164, 1999.

REIGADA, Antonio Troncoso. Privatización, empresa publica y constitución. Madrid: Marcial Pons, 1997.

REIS, Elisa Pereira; SCHWARTZMAN, Simon. Pobreza e exclusão social: aspectos sócio políticos. Trabalho preparado por solicitação do Banco Mundial como contribuição para um estudo em andamento sobre a exclusão social no Brasil. 2005. Disponível em: http://www.schwartzman.org.br/sitesimon/?page_id=546\&lang=pt-br. Acesso em: 12 maio 2009.

REZENDE, Sonaly. Aspectos demográficos da cobertura de serviços de saneamento no Brasil urbano contemporâneo. Tese (Doutorado em Demografia do Centro de Desenvolvimento e Planejamento Regional) - Faculdade de Ciências Econômicas da Universidade Federal de Minas Gerais, Belo Horizonte, 2005.

RICHER, Laurent. Service public et intérêt privé. Archives de Philosophie du Droit. Paris, n. 41, p. 293-300, 1997.

RODRIGUES, Stephane. Prospective du service public en Europe. Revue des Affaires Européennes, Paris, n. 2, p. 65-79, 1994.

ROVIRA, Enoch Alberti. Las Relaciones de Colaboracion entre el Estado y Las Comunidades Autônomas. Revista Española de Derecho Constitucional, Año 5, n. 14, 1985.

SADDI, Fabiana da Cunha. Estado e federalismo no governo Geisel: uma análise do federalismo na gênese da transição política brasileira. Dissertação (Mestrado em Ciência Política ) - Faculdade de Filosofia, Letras e Ciências Humanas da Universidade de São Paulo, São Paulo, 1999.

SAHLINS, Marshal. Esperando Foucault, ainda. São Paulo: Cosac Naify, 2004.

SALOMÃO FILHO, Calixto. Direito concorrencial: as estruturas. 2. ed. São Paulo: Malheiros, 2002a. 
SALOMÃO FILHO, Calixto. Regulação da atividade econômica. São Paulo: Malheiros, 2001.

SALOMÃO FILHO, Calixto. Regulação e desenvolvimento. In: SALOMÃO FILHO, Calixto (Coord.). Regulação e desenvolvimento. São Paulo, 2002.

SALOMONI, Jorge Luis. Teoria general de los servicios públicos. Buenos Aires: Ad-hoc, 1999.

SANTIAGO, José M. Rodríguez de. Los convenios entre administraciones públicas. Madrid: Marcial Pons, 1997.

SANTOS NEVES, Rodrigo. O Estado regulador: a dignidade humana como princípio informador da regulação do mercado. Revista Trimestral de Direito Público, São Paulo, n. 33, p. 211-228, 2001.

SANTOS, Fabiano. A República de 46. In: MELO, Carlos Ranulfo. Sáez, Manuel Alcântara. A democracia brasileira (Org.). A democracia brasileira. Belo Horizonte: Editora UFMG, 2007.

SANTOS, Milton. A urbanização brasileira. São Paulo: Edusp, 2008.

SANTOS, Wanderley Guilherme dos. O cálculo do conflito: estabilidade e crise na política brasileira. Belo Horizonte: Editora UFMG; Rio de Janeiro: IUPERJE, 2003.

SCHWARTZMAN, Simon. Bases do autoritarismo brasileiro. Rio de Janeiro: Publit Soluções Editoriais, 2007.

SILVA, Vasco Manuel Pascoal Dias Pereira da. Em busca do acto administrativo perdido. Coimbra: Almedina, 2003.

SILVEIRA DIAS, Raquel. Gestão de recursos hídricos e as deficiências do serviço de saneamento básico no Brasil. Revista Fórum de Direito Urbano e Ambiental, Belo Horizonte, n. 6, p. 539-543, nov./dez. 2002.

SILVEIRA DIAS, Raquel. O repensar da noção de serviço público sob o paradigma da realidade brasileira. In: FERRAZ, Luciano; MOTTA, Fabrício (Org.). Direito público moderno. Belo Horizonte: Del Rey, 2003, p. 97-117. 
SILVEIRA, Alessandra. Cooperação e compromisso constitucional dos estados compostos. Coimbra: Almedina, 2007.

SISTEMA NACIONAL DE INFORMAÇÕES SOBRE O SANEAMENTO (SNIS). Programa de Modernização do Setor Saneamento Sistema Nacional de Informações sobre Saneamento: diagnóstico dos serviços de água e esgotos, 2006. Brasília: MCIDADES; SNSA, 2007.

SOTO, Jean de. Grandes services publics et entreprises nationales. Paris: Montchrestien, 1971.

SOUTO, Marcos Juruena Villela. Desestatização. 4. ed. Rio de Janeiro: Lumen Juris, 2001.

SOUTO, Marcos Juruena Villela. Gestão alternativa de serviços públicos. Revista de Direito Administrativo, Rio de Janeiro, n. 219, p. 179-203, jan./mar. 2000.

SOUZA, Celina. Regiões Metropolitanas: trajetória e influência das escolhas institucionais. In: RIBEIRO, Luiz Cesar de Queiroz (Org.). Metrópoles: entre a coesão e a fragmentação, a cooperação e o conflito. São Paulo: Editora Fundação Perseu Abramo; Rio de Janeiro: Federação de Órgãos para Assistência Social e Educacional (FASE), 2004.

SUNDFELD, Carlos Ari. Introdução às Agências Reguladoras. In: SUNDFELD, Carlos Ari (Org.). Direito administrativo econômico. São Paulo: Malheiros, 2002.

SUNDFELD, Carlos Ari. O saneamento básico e sua execução por empresa estadual. Revista Diálogo Jurídico, Salvador, v. I, n. 5, ago. 2001. Disponível em: <http://www.direitopublico.com.br>. Acesso em: 5 out. 2006.

SUPIOT, Alain. La crise de l'esprit de service public. Droit Social, Paris, n. 12, p. 777-783, déc. 1989.

TÁCITO, Caio. A configuração jurídica do serviço público. Revista de Direito Administrativo, Rio de Janeiro, n. 233, p. 373-376, jul./set. 2003.

TÁCITO, Caio. A reforma do estado e a modernidade administrativa. Revista de Direito Administrativo, Rio de Janeiro, n. 215, p. 1-7, jan./mar. 1999.

TÁCITO, Caio. Saneamento básico - Região Metropolitana - Competência estadual. Revista de Direito Administrativo, Rio de Janeiro, n. 222, p. 307-310, out./dez. 2000. 
TÁCITO, Caio. Serviços de saneamento básico. Revista de Direito Administrativo, Rio de Janeiro, n. 229, p. 1-4, jul./set. 2002.

TANAKA, Sônia Yuniko Kanashiro. O poder concedente dos serviços de saneamento básico, sobretudo na região metropolitana de São Paulo: Estado ou Município? Boletim de Direito Municipal, São Paulo, p. 466-474, jun. 2005.

TEIXEIRA, Ana Carolina Wanderley. Região metropolitana: instituição e gestão contemporânea. Dimensão participativa. Belo Horizonte: Fórum, 2005.

TOKESHI, Hélcio. Direto da frente de batalha: a promoção da concorrência em mercados regulados. In: SALGADO, Lucia Helena; SEROA, Ronaldo. (Org.) Regulação e concorrência no Brasil: governança, incentivos e eficiência. Rio de Janeiro: Ipea, 2007.

TUCCI, Carlos. Gestão de águas pluviais urbanas. Brasília: Ministério das Cidades, 2006.

TUROLLA, Frederico Araújo Pontos para uma discussão sobre eficiência e regulação em saneamento. In: SALGADO, Lucia Helena; MOTTA, Ronaldo Seroa da (Org.). Regulação e concorrência no Brasil: governança, incentivos e eficiência. Rio de Janeiro: Ipea, 2007.

TUROLLA, Frederico Araújo. Provisão e operação de infra-estrutura no Brasil: o setor de saneamento. Dissertação (Mestrado em: Economia) - Fundação Getúlio Vargas, São Paulo, 1999.

TUROLLA, Frederico Araújo; OHIRA, Thelma Harumi. Saneamento básico: experiência internacional e avaliação de propostas para o Brasil. Brasília: CNI, 2006. 63 p.

VALLE, Lúcia. Competências administrativas dos estados e municípios. Revista de Direito Administrativo, Rio de Janeiro, n. 207, p. 1-19, jan./mar. 1997.

WALD, Arnoldo. Do regime jurídico da concessão e da subconcessão para prestação de serviços públicos de saneamento básico no Município de Petrópolis. Revista de Direito Administrativo, Rio de Janeiro, n. 225, p. 217-219, jul./set. 2001.

WALD, Arnoldo; MORAES, Rangel; WALD, Alexandre de M. O direito da parceria e a lei de concessões. São Paulo: Saraiva, 2004.

WILLEMAN, Flávio de Araújo. O princípio da generalidade e o direito ao recebimento de serviços públicos ainda não prestados em caráter geral. Revista de Direito Administrativo, Rio de Janeiro, n. 227, p. 111-130, jan./mar. 2002. 
YURIKO, Sônia; TANAKA, Kanashiro. Poder concedente dos serviços de saneamento básico, sobretudo na região metropolitana de São Paulo: estado ou município? Boletim de Direito Municipal, São Paulo, n. 6, p. 466-474, 2005.

ZIMMERMANN, Augusto. Teoria geral do federalismo democrático. Rio de Janeiro: Lumen Juris, 1999. 